Claudius de Sousa Barbosa

\title{
RESISTÊNCIA E DEFORMABILIDADE DE BLOCOS VAZADOS DE CONCRETO E SUAS CORRELAÇÕES COM AS PROPRIEDADES MECÂNICAS DO MATERIAL CONSTITUINTE
}

\begin{abstract}
Dissertação apresentada à Escola de Engenharia de São Carlos da Universidade de São Paulo, como parte dos requisitos para a obtenção do Título de Mestre em Engenharia de Estruturas.
\end{abstract}

Orientador: Prof. Titular João Bento de Hanai 
Ficha catalográfica preparada pela Seção de Tratamento da Informação do Serviço de Biblioteca - EESC/USP

B238r

Barbosa, Claudius de Sousa

Resistência e deformabilidade de blocos vazados de concreto e suas correlações com as propriedades mecânicas do material constituinte / Claudius de Sousa Barbosa. -São Carlos, 2004.

Dissertação (Mestrado) -- Escola de Engenharia de São Carlos-Universidade de São Paulo, 2004.

Área: Engenharia de Estruturas.

orientador: Prof. Tit. João Bento de Hanai.

1. Alvenaria estrutural. 2. Blocos vazados de concreto. 3. Resistência. 4. Deformabilidade.

5. Propriedades mecânicas. 6. Análise experimental.

I. Título. 


\section{FOLHA DE JULGAMENTO}

Candidato: Engenheiro CLAUDIUS DE SOUSA BARBOSA

Dissertação defendida e julgada em 23-04-2004 perante a Comissão Julgadora:

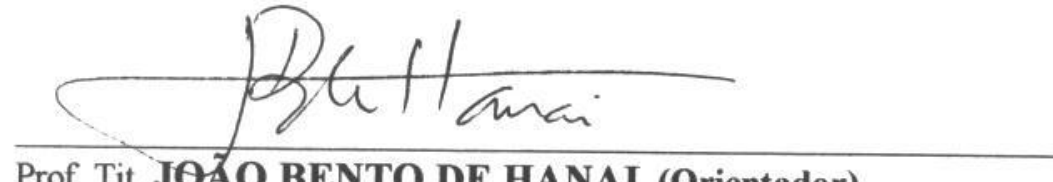

APROVADO

Prof. Tit. JOǍO BENTO DE HANAI (Orientador)

(Escola de Engenharia de São Carlos/USP)

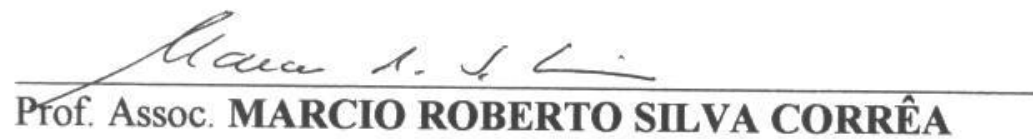

(Escola de Engenharia de São Carlos/USP)
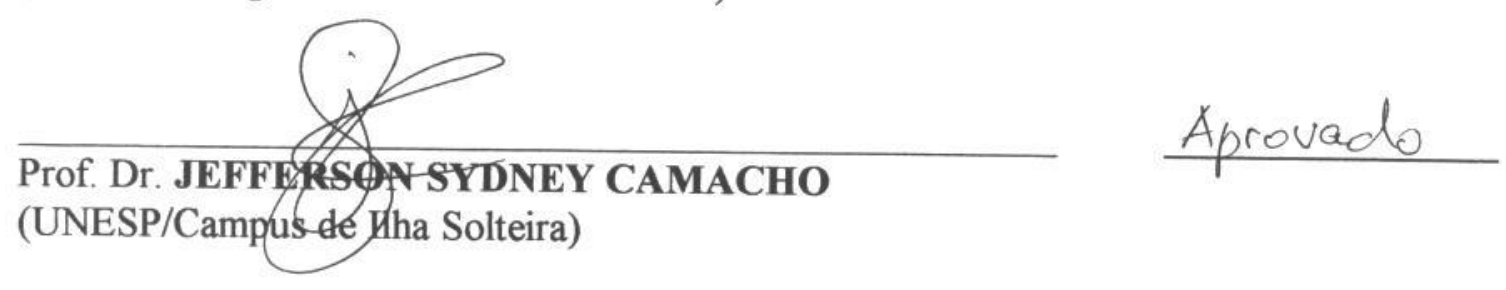

(UNESP/Campus de tha Solteira)

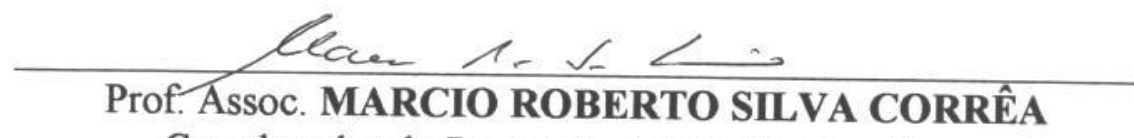

Coordenador do Programa de Pós-Graduação em

Engenharia Civil (Engenharia de Estruturas)

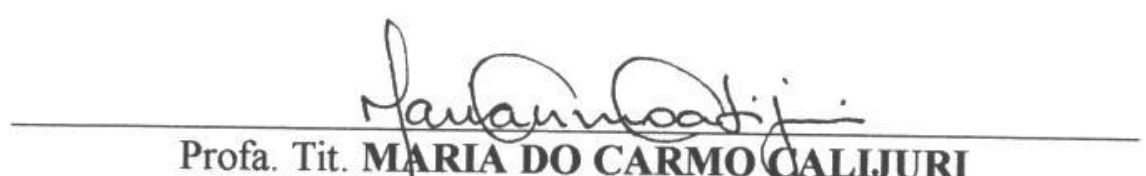

Profa. Tit. MARIA DO CARMO OALIJURI

Presidente da Comissão de Pós-Graduação 
Aos meus pais, Eunice e Cláudio, com amor. 


\section{AGRADECIMENTOS}

A Deus, por mais essa oportunidade e por toda a força ao longo da minha vida.

Ao Professor João Bento de Hanai pela cuidadosa orientação, valiosas idéias e, acima de tudo, pelo empenho, entusiasmo e dedicação em todas as etapas deste trabalho.

Aos meus pais, Eunice e Cláudio, exemplos em minha vida, por toda a educação e humildade que me transmitiram. Sou eternamente agradecido pelo apoio incondicional, sem o qual não alcançaria meus êxitos.

À minha irmã Tatiana por todo apoio, carinho e incentivos.

A Anna Rachel, exemplo de companheirismo, a quem aprendi a admirar e orgulhar-me ao longo desses dois anos. Obrigado pelos incentivos, sugestões e compreensão. Você faz parte deste trabalho e representa muito para mim.

Aos meus avôs Alzira Gomes Barbosa e João Juventino de Souza, por tudo.

Aos demais familiares que de alguma forma me incentivaram nessa longa caminhada.

A Marcus André, amigo de todas as horas, pelos incentivos e entusiasmo com meu trabalho.

Aos amigos Selma, Petrus e Patrícia, que proporcionaram a estadia em São Carlos mais alegre e prazerosa.

Aos amigos do Departamento de Estruturas, pelas ajudas e grato convívio, em especial: Clayton, Edson, Fabiana Oliveira, Geílson, Jerônymo, Josafá, Larissa, Luciano, Márcio Félix, Murilo, Oscar Begambre, Ricardo Carrazedo, Tiago e Walter.

Aos funcionários do Laboratório de Estruturas pelo empenho na parte experimental: Luis Vareda, Amauri, Vagner, Fabiano, Valdemir, Mário, Valdir e Mauri.

À CAPES - Coordenação de Aperfeiçoamento de Pessoal de Nível Superior pela bolsa de Mestrado inicialmente concedida.

À FAPESP - Fundação de Amparo à Pesquisa do Estado de São Paulo - pela bolsa de Mestrado e Auxílio à Pesquisa concedidos, os quais foram fundamentais no desenvolvimento da pesquisa.

À Monolite, na pessoa do Eng. Danilo, pelos prismas de EPS fornecidos. 


\section{ÍNDICE}

RESUMO

viii

ABSTRACT

ix

\section{INTRODUÇÃO}

1.1 BREVE HISTÓRICO

1.2 JUSTIFICATIVAS 4

1.3 OBJETIVos 6

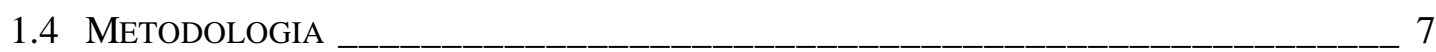

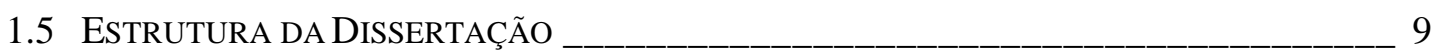

2. REVISÃO BIBLIOGRÁFICA — 10

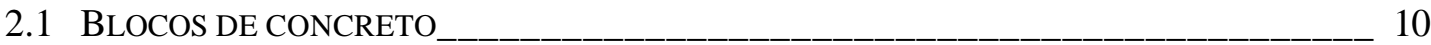

2.2 ARgAMASSA DE ASSENTAM ENTO ________________________________________ 14

2.3 FATORES QUE INTERFEREM NA RESISTÊNCIA À COMPRESSÃO DOS ELEMENTOS DE

ALVENARIA __ 16

2.3.1 Geometria dos elementos __ 17

2.3.2 Resistência das unidades___ 21

2.3.3 Espessura da junta de argamassa___ 23

2.3.4 Resistência da argamassa__ 25

2.3.5 Capeamento___ 27

2.3.6 Influência das placas de ensaio __ 30

2.4 ENSAIOS COM MATERIAL QUE CONSTITUI O BLOCO__________________________ 34

2.5 ENSAIOS COM MATERIAIS SUBSTITUINDO A JUNT A DE ARGAMASSA _-___________ 44

2.6 COMPORTAMENTO DOS ELEMENTOS DE ALVENARIA_______________________________ 46

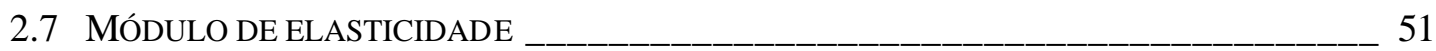

3. PRODUÇÃO E ENSAIOS DOS ELEMENTOS DE CONCRETO__ 55

3.1 DESCRIÇÃO DO CONCRETO UTILIZADO ____________________________________ 55

3.1.1 Caracterização dos materiais empregados na fabricação do concreto _ 56

3.2 ETAPAS DO PROCESSO DE PRODUÇÃO DOS ELEMENTOS_______________________ 57

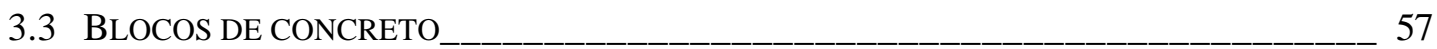

3.3.1 Produção__ 57

3.3.2 Detalhamento dos ensaios. _ 60

3.3.2.1 Instrumentação

3.3.2.2 Comportamento dos blocos

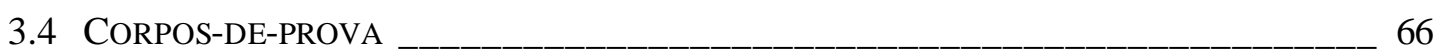

3.4.1 Produção__ 66

3.4.2 Detalhamento dos ensaios___ 68

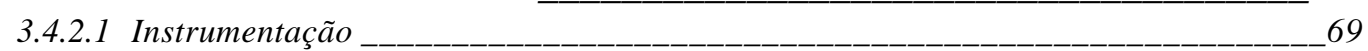

3.4.2.2 Comportamento dos corpos-de-prova

3.5 BLOCOS ASSOCIADOS SEM JUNTA DE ARGAMASSA __________________________ 72

3.5.1 Instrumentação __ 74 
4.1 CARACTERIZAÇÃO DA RESISTÊNCIA DO CONCRETO ___________________________ 83

4.2 CARACTERIZAÇÃO DA RESISTÊNCIA DOS BLOCOS DE CONCRETO________________ 85

4.3 RESISTÊNCIA À COMPRESSÃO E DEFORMABILIDADE DE BLOCOS E CORPOS-DE-PROVA 87

4.3.1 Grupo 10

4.3.2 Grupo 20

4.3.3 Grupo 30_ 96

4.3.4 Considerações sobre os ensaios com blocos de concreto___ 99

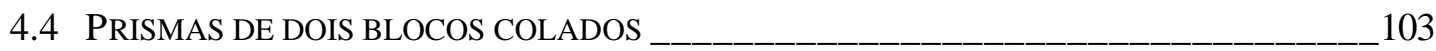

4.4.1 Grupo $10 \_103$

4.4.2 Grupo $20 \_106$

4.4.3 Grupo 30_ 109

4.5 PRISMAS DE 3 BLOCOS COLADOS___________________________________________ 111

4.5.1 Grupo $10 \_112$

4.5.2 Grupo $20 \_114$

4.5.3 Grupo 30_ 117

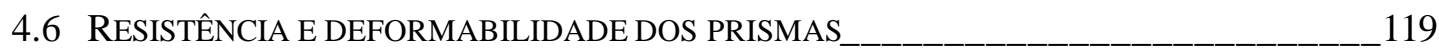

5. ANÁLISE TEÓRICA E CONFRONTAÇÃO DE RESULTADOS _ 120

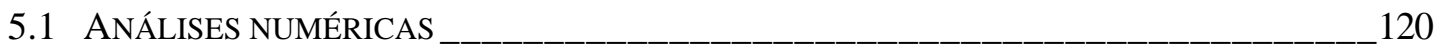

5.1.1 Discretização da malha e propriedades mecânicas dos materiais___ 121

5.1.2 Deslocamento não uniforme da placa de ensaio ___ 123

5.1.3 Deslocamento uniforme da placa de ensaio ___ 127

5.1.4 Considerações sobre os modelos __ 130

5.2 ANÁLISE POR ASSOCIAÇÃO DOS RESULTADOS EXPERIMENTAIS _____________________ 132

5.2.1 Cálculo da força teórica resistente do bloco _ـ 132

5.2.2 Sobre a curva força-deslocamento do bloco vazado de concreto__ 135

5.2.3 Deformabilidade do bloco vazado de concreto____ 137

6. CONCLUSÃO _ 141

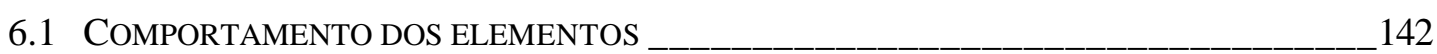

6.2 PROPRIEDADES MECÂNICAS DOS ELEMENTOS E DEFORMAÇÃo DO BLOCO __________ 142

6.3 SOBRE A ANÁlISE TEÓRICA___________________________________________________ 144

6.4 PRoposta PARA trabalHoS FUtURoS_______________________________________ 145

7. REFERÊNCIAS BIBLIOGRÁFICAS — 146

8. BIBLIOGRAFIA COMPLEMENTAR 152 


\section{RESUMO}

BARBOSA, C.S. (2004). Resistência e deformabilidade de blocos vazados de concreto $e$ suas correlações com as propriedades mecânicas do material constituinte. Dissertação (Mestrado) - Escola de Engenharia de São Carlos, Universidade de São Paulo, São Carlos, 2004.

O trabalho tem como objetivo correlacionar as propriedades mecânicas de blocos vazados com as do concreto que o constitui. Moldam-se blocos vazados e corpos-deprova de dimensões distintas com concreto plástico em três níveis de resistência $(10,20$ e $30 \mathrm{MPa}$ ) e caracterizam-se as propriedades mecânicas por meio de ensaios à compressão axial e à tração. Ensaiam-se à compressão axial prismas constituídos por dois e três blocos de concreto sem junta de argamassa, unidos por adesivo à base de epóxi. Observa-se que a relação entre as resistências do bloco e prisma e a resistência do concreto diminui com o aumento da altura desses elementos. Obtém-se o módulo de elasticidade longitudinal do concreto, a partir de ensaios com corpos-de-prova. Analisam-se as deformações em diversos pontos do bloco quando submetidos à compressão axial. Devido à distribuição não uniforme de tensões nos blocos e prismas, obtêm-se diferentes valores de deformação ao longo das paredes dos elementos. Os blocos, por possuírem menor altura que os prismas, apresentam maior diferença entre os valores de deformação. Por meio de simulações numéricas, no regime linear, observa-se que a placa de ensaio não se desloca uniformemente, acarretando os distintos valores de deformação ao longo do bloco. Uma forma peculiar de cálculo, baseada nessas deformações, permite a previsão da capacidade resistente do bloco e conduz a valores próximos da força máxima de ensaio. Apresenta-se ainda, uma tentativa de prever a deformabilidade do bloco vazado de concreto a partir das propriedades mecânicas do concreto.

Palavras-chave: alvenaria estrutural; blocos vazados de concreto; resistência; deformabilidade; propriedades mecânicas; análise experimental. 


\begin{abstract}
BARBOSA, C.S. (2004). Strength and deformability of concrete hollow blocks and their correlation to mechanical properties of constituent material. M.Sc. Degree Thesis - Escola de Engenharia de São Carlos, Universidade de São Paulo, São Carlos, 2004.
\end{abstract}

This research aims to correlate the mechanical properties of hollow blocks to those of the concrete used to build them. Concrete hollow blocks and test samples of different shapes and sizes (cylinder $50 \times 100,100 \times 200$ and $150 \times 300 \mathrm{~mm}$ ) were molded with plastic consistency concrete in three different levels of strength (nominally 10, 20 and $30 \mathrm{MPa}$ ). Their mechanical properties and structural behavior in axial compression and tension tests were determined. Also two and three block prisms were built without mortar joints, pilled up with epoxy glue. It could be observed that the relationship between block strength or prism strength and concrete strength (measured in test samples) decreases with increasing of the element's height. Stress and strain analyses were made based on the concrete's modulus of elasticity obtained in sample tests and on the measured strain in the blocks' faces and webs. By linear numerical simulations it was observed that loading plate does not show uniform displacement values, causing significant differences between theoretical and experimental behavior. A peculiar stressstrain analysis permitted to calculate the block load capacity based in its deformations. Also a tentative method to preview the block deformability from the concrete mechanical properties is described and tested.

Keywords: structural masonry; concrete hollow blocks; strength; deformability; mechanical properties; experimental analysis. 


\section{INTRODUÇÃO}

O número de edifícios em Alvenaria Estrutural no Brasil cresceu significativamente nos últimos 20 anos, a partir da consolidação de suas técnicas construtivas e da necessidade de racionalização estimulada pela acirrada concorrência no campo da Construção Civil. Além disso, esse sistema mostra-se apropriado para suprir o déficit habitacional dos países em desenvolvimento pela sua adequação tecnológica às necessidades técnicas e costumes locais e à possibilidade de desenvolvimento de um processo racional desde o projeto à execução da obra.

De acordo com Ramalho e Corrêa (2003) " “[...] o Brasil ainda estaria aprendendo a utilizar esse sistema construtivo", pois a completa consolidação da técnica se retarda diante da escassez da literatura sobre o assunto, da inadequação de parte dos materiais empregados e da ausência de uma norma específica. No entanto, segundo a Téchne $(2003)^{2}$, já se constroem edifícios em Alvenaria Estrutural de alto padrão nas grandes cidades brasileiras, com flexibilidade de layout, balanços, varandas e vãos maiores que os comumente utilizados. Um dos maiores edifícios em alvenaria do país, de acordo com Téchne $(2004)^{3}$, o hotel Plaza Inn - com 56 m de altura e $10 \mathrm{~m}$ de largura - possui vãos de até 3,30 x 8,40 m. É também destacado que as barreiras antes existentes, que tratavam de tal tecnologia como sendo de solução construtiva limitada e destinada apenas a obras populares, estão superadas.

Além da racionalização do projeto, a racionalização estrutural, a redução do tempo de execução, a subdivisão de espaços - função simultaneamente desempenhada pela estrutura -, o isolamento térmico e acústico, a proteção ao fogo e a redução de camadas de revestimento estão entre as principais vantagens desse sistema construtivo.

\footnotetext{
${ }^{1}$ RAMALHO, M.A.; CORRÊA, M.R.S. (2003). Entrevista: Alvenaria estrutural sem segredos. Técnhe, São Paulo, ano XI, ed.76, p.30-36, jul.

2 TÉCHNE: A redescoberta da alvenaria estrutural (2003). São Paulo, ano XI, ed.75, jun.

3 TÉCHNE: Dezoito pavimentos sobre blocos (2004). São Paulo, ano XII, ed. 82, jan.
} 


\subsection{Breve histórico}

"Empilhando pedra sobre pedra, os construtores foram capazes de criar a maioria das imponentes estruturas da história antiga." (LEFER, 1976) ${ }^{4}$.

A Alvenaria é um dos mais clássicos sistemas construtivos da contemporaneidade. Porém, tal técnica já era conhecida há milhares de anos e desde as idades mais antigas podem ser relatados exemplos de construções em alvenaria. É bem verdade que algumas dessas obras não apresentavam nenhuma grande inovação tecnológica do ponto de vista estrutural, como é o caso das pirâmides de Gizé, exemplificadas por Ramalho e Corrêa (2003). Estruturalmente, elas nada mais eram que o "empilhamento de pedra sobre pedra", porém as grandes dificuldades encontradas à época - como a falta de conhecimento técnico, a dificuldade m execução das obras e o desconhecimento das propriedades dos materiais - tornaram essas obras admiráveis. A maior das três pirâmides de Gizé, a Grande Pirâmide (Figura 1.1), é a única das sete maravilhas do mundo que se mantém em pé. Quando construída, possuía 147,75 m de altura e foi edificada com mais de 2 milhões de blocos que pesavam cerca de 2,5 toneladas. Vale ainda enaltecer que essas obras se mostraram extremamente duráveis, visto que a sua construção data aproximadamente de 2600 a.C. Admirável também é a superação das dificuldades encontradas para o transporte e içamento das pesadas pedras.

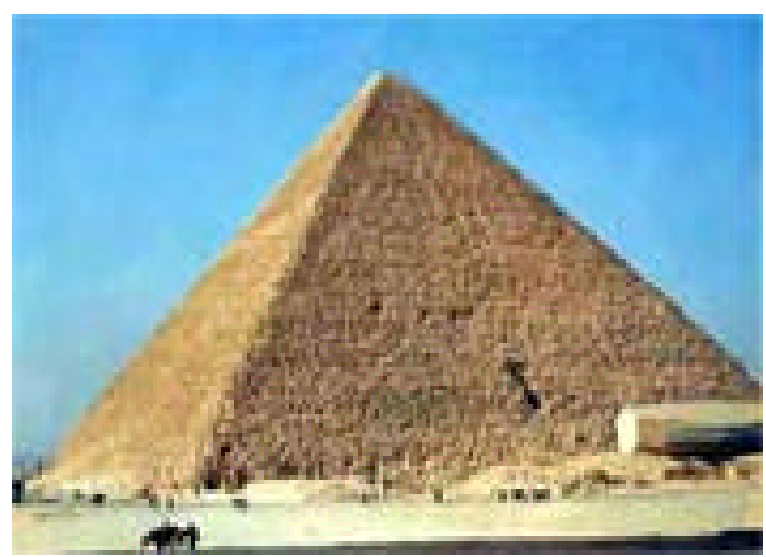

Figura 1.1 - A Grande Pirâmide de Gizé, Portalmix (2003)

O Farol de Alexandria (280 a.C.) e o Coliseo de Roma (80 d.C.) podem ainda ser citados como outras obras em alvenaria de grande valor histórico. Drysdale et al.

\footnotetext{
4 LEFER, H. (1976). What's new on the old the block. Progressive Architecture, v.12, p.82-88.

5 PORTALMIX (2003). Disponível em:

<http://www.portalmix.com/misterios/monograficos/piramides/granpiramide.shtml>. Acesso em: 17 ago.
} 
(1994) afirmam que o significativo avanço estrutural começou com a construção dos primeiros arcos em alvenaria por volta de 1400 a.C. Essas estruturas tinham a capacidade de vencer grandes vãos utilizando apenas elementos comprimidos. Além do Coliseo de Roma, os arcos góticos são exemplos clássicos, como o construído na Catedral Gerona, na Espanha, em 1598, com um vão de 22,3 metros. Ramalho e Corrêa (2003) relatam que tais arcos sustentavam os tetos apoiados em pilares esbeltos, muitas vezes contraventados externamente por outros arcos. A Figura 1.2 ilustra a utilização dos arcos de alvenaria.

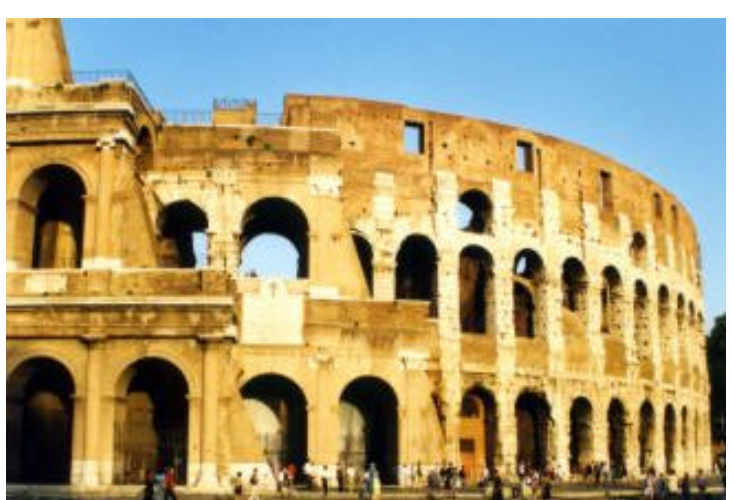

(a)

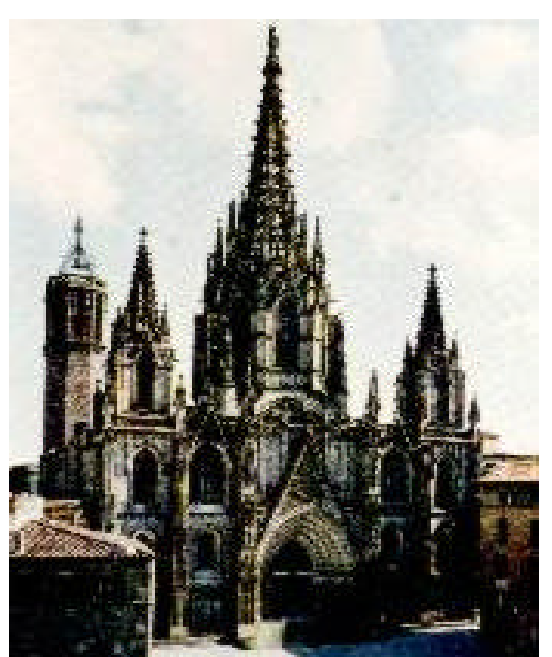

(b)

Figura 1.2 - Coliseo de Roma (a), UAM (2003) ${ }^{6}$. Catedral de Barcelona (b), Hiares (2003) ${ }^{7}$

Considerado um marco da construção em alvenaria, o edifício Monadnock foi executado em Chicago, em fins do século XIX, com tijolos cerâmicos, possuindo 16 pavimentos e $65 \mathrm{~m}$ de altura. Representa a última grande obra em alvenaria em que foi utilizado processo empírico em seu dimensionamento, fato esse que levou à utilização de uma espessura de $180 \mathrm{~cm}$ nas paredes da base. A espessura foi reduzida gradualmente até cerca de $30 \mathrm{~cm}$ nas paredes do alto do edifício, todavia, estima-se que se utilizados os métodos de dimensionamento atuais, juntamente com os mesmos materiais utilizados na época, a espessura da parede na base poderia ser menor que 30 $\mathrm{cm}$.

Diante das vantagens técnicas e econômicas do concreto armado e do aço, as estruturas de alvenaria foram substituídas por essas novas tecnologias, que possibilitavam a construção de obras até então apenas sonhadas.

\footnotetext{
6 UNIVERSIDAD AUTÓNOMA METROPOLITANA (2003). Disponível em: <http://fenix.uam.mx/romy/photos/index_photos.html>. Acesso em: 17 ago.

7 HIARES (2003). Disponível em: <http://www.hiares.es/10218.html>. Acesso em: 17 ago.
} 
Conforme relata Gomes (1983), as primeiras especificações e métodos de ensaios nacionais datam da década de 1940, oriundos de estudos realizados por uma “Comissão Especial" designada pelo Instituto de Engenharia de São Paulo. Essas normas tratavam especificamente de tijolos de barro cozido para alvenaria. Na Inglaterra era elaborada, na mesma época, a primeira norma consistente para o cálculo de alvenaria de tijolos.

Na década de 1950, foi construído, na Suíça, o primeiro edifício em alvenaria estrutural não-armada, constituído de 13 pavimentos. Essa obra marca a consideração de princípios de Engenharia Estrutural para os projetos.

No Brasil, o surgimento dessas estruturas é atribuído à construção dos edifícios do condomínio Central Parque Lapa, em São Paulo, entre 1967 e 1972. Esses edifícios foram erguidos em alvenaria armada, sendo a alvenaria não-armada empregada pioneiramente apenas em 1977, em edificações de nove pavimentos com blocos silicocalcários, conforme relatam Ramalho e Corrêa (2003).

Medeiros (1993) considera que o aumento na utilização desse processo construtivo não foi acompanhado do desenvolvimento tecnológico, em que se dispusesse de uma normalização adequada, e que isso persistirá até que a tecnologia desenvolvida seja amplamente testada, normalizada e de uso corrente. Esta incoerência pode ser justificada por Camacho (1986) que, em relação à pesquisa e ao emprego de estruturas em alvenaria, considera ter ocorrido um processo inverso. Para o autor, o início das pesquisas apenas no final da década de 1970 e princípios da década de 1980 gerou confusão no meio técnico devido ao não completo entendimento da alvenaria estrutural, o que levou a um errado emprego da nova técnica e a conseqüente procura por normas internacionais que não condizem com a realidade brasileira.

\subsection{Justificativas}

Mesmo com a evolução científica por que passou a tecnologia da Alvenaria Estrutural, ao longo dos últimos anos, os métodos de dimensionamento e verificação da segurança estrutural ainda se baseiam em dados empíricos em muitos aspectos. Por exemplo, o Método das Tensões Admissíveis ainda é o preconizado pela NBR 10837 (1989) para o dimensionamento de paredes e pilares de alvenaria à compressão axial. Esse método, de acordo com Hendry (2001), é de cálculo simples, mas sem a facilidade de ajustar o projeto às diferenças observadas, como nas condições de carregamento, nas 
propriedades dos materiais e nos níveis de qualidade da mão-de-obra. Já Ramalho e Corrêa (2003) apontam sérias deficiências no eferido método, por considerarem a impossibilidade de se interpretar o coeficiente de segurança como sendo um coeficiente externo, pela preocupação única com a relação serviço-ruptura e pela adequação apenas para o comportamento linear.

O Método dos Estados Limites, já empregado na análise de estruturas de concreto há mais de 30 anos, representa um avanço em relação ao Método das Tensões Admissíveis. Ele vem sendo implementado em diversos manuais e normas técnicas sobre alvenaria em países estrangeiros.

Como exemplo de normas baseada nos Estados Limites, Hendry (2001) exemplifica a BS 5628 (1992) e o Eurocódigo 6 (1995). Cavalheiro e Gomes (2002) citam ainda que, recentemente nos Estados Unidos, três diferentes associações, o ACI (American Concrete Institute), a ASCE (American Society of Civil Engineers) e a TMS (The Masonry Society) elaboraram um código para estruturas de alvenaria, o Building Code Requirements for Masonry Structures ${ }^{8}$, ainda fundamentado nas tensões admissíveis, deixando para o futuro um capítulo para os estados limites últimos.

Entretanto, o conhecimento atual ainda não tem permitido o estabelecimento claro de um conjunto de parâmetros e seus respectivos coeficientes de ponderação e de segurança. É preciso avançar, esmiuçando ainda mais os fitores que se referem aos materiais, aos processos de produção dos componentes, aos processos construtivos dos elementos estruturais e à estrutura como um todo.

Para a aplicação do conceito de estados limites, é necessário isolar e conhecer melhor cada uma das variáveis que intervêm no comportamento estrutural em serviço e estado limite último, sendo necessário estabelecer coeficientes de ponderação a essas variáveis.

Nesse contexto, nota-se a escassez de trabalhos que detalhem o comportamento estrutural de blocos vazados de concreto, além da falta de correlações entre as propriedades mecânicas dos blocos e as do material que o constituem (resistência à compressão, resistência à tração e módulo de elasticidade), obtidas por meio de ensaios em corpos-de-prova, variando-se apenas a forma do elemento ensaiado. Nota-se, ainda, a falta de um método de determinação da rigidez axial dos blocos vazados de concreto e

8 MASONRY STANDARDS JOINT COMMITTEE (1999). ACI 530-99/ASCE 5-99/ TMS 402-99: Building code requirements for masonry structures. 
de trabalhos que analisem teoricamente as tensões e as deformações nas paredes que constituem esse elemento estrutural.

\subsection{Objetivos}

Num horizonte mais distante do desenvolvimento científico da Alvenaria Estrutural, as seguintes condições podem ser vislumbradas: os materiais empregados poderão ter melhor definidos os parâmetros de interesse para a análise estrutural; modelos algébricos e numéricos serão aperfeiçoados, possibilitando a análise de estruturas sob diversas condições de solicitação; modelos estatísticos e determinísticos poderão representar mais adequadamente os fenômenos físicos envolvidos e as variabilidades dos processos de produção dos componentes e execução de elementos estruturais, aperfeiçoando os procedimentos de controle; um método mais adequado de verificação da segurança estrutural estará disponível.

O presente trabalho tem como objetivo definir melhor as propriedades mecânicas dos materiais de interesse para análise estrutural empregados na Alvenaria, tais como resistência à compressão, resistência à tração e módulo de elasticidade. Neste sentido, visa analisar o comportamento estrutural de blocos vazados de concreto e correlacioná-lo com as propriedades dos materiais constituintes.

Os objetivos específicos são definidos a seguir:

- Correlacionar as propriedades mecânicas do material que constitui o bloco, obtidas em ensaios padronizados de corpos-de-prova cilíndricos, com as propriedades dos blocos, também determinadas em ensaios;

- Identificar e interpretar teórica e experimentalmente os efeitos de forma (geométrica) e de distribuição de tensões em blocos vazados de concreto, coletando dados para investigação mais detalhada no futuro;

- Por meio de simulações numéricas, comparar a distribuição de deformações no bloco em função do deslocamento da placa de ensaio;

- Desenvolver uma forma de avaliação da rigidez axial de blocos isolados, com vistas à sua aplicação na análise de prismas e paredes;

- Estabelecer relações de dependência entre os parâmetros usuais referentes aos materiais (resistência à compressão e à tração, módulo de 
elasticidade e curva tensão-deformação) e o comportamento estrutural dos blocos.

\subsection{Metodologia}

Para possibilitar condições semelhantes de moldagem e adensamento de corpos-de-prova e blocos vazados de concreto, utilizou-se concreto plástico em três níveis de resistência. Os blocos foram produzidos no Laboratório de Estruturas da Escola de Engenharia de São Carlos, em fôrmas metálicas especialmente projetadas para o trabalho.

Ensaiaram-se isoladamente blocos submetidos à compressão axial, buscando coletar dados para análise geral do seu comportamento. Para verificar a alteração do comportamento desse elemento, variando-se as suas dimensões, realizou-se uma série de ensaios com dois e três blocos associados sem junta de argamassa. Correlacionam-se as propriedades mecânicas dos materiais, obtidas em corpos-de-prova, com as obtidas em ensaios de blocos isolados e blocos associados.

Realizam-se análises numéricas identificando a distribuição de tensões e deformações que ocorrem nesses elementos, variando as condições de ensaio e comparando esses resultados. As análises estão limitadas ao comportamento linear dos elementos.

O Quadro 1.1 apresenta a estrutura geral dos objetivos e da metodologia em função de premissas inicialmente estabelecidas, bem como ações de pesquisa a serem empreendidas e limitações de abrangência. 
Quadro 1.1 - Quadro inicial de referência.

\begin{tabular}{|c|c|c|}
\hline Premissa & Ação & Limitação \\
\hline $\begin{array}{l}\text { Não se conhecem estudos experimentais que } \\
\text { correlacionem a resistência à compressão do concreto, } \\
\text { medida em corpos-de-prova cilíndricos, e a resistência à } \\
\text { compressão de blocos vazados de concreto, conside- } \\
\text { rando apenas os efeitos de forma (geométrica). }\end{array}$ & $\begin{array}{l}\text { Realizar simulações experimentais sobre corpos-de- } \\
\text { prova cilíndricos e blocos de concreto moldados em } \\
\text { fôrmas especiais, para identificação experimental dos } \\
\text { efeitos da forma geométrica e coleta de dados para } \\
\text { futuras análises teóricas. }\end{array}$ & $\begin{array}{l}\text { Pelo que se sabe, esse tipo de ensaio não é amplamente } \\
\text { difundido, portanto, é possível que as séries de ensaio } \\
\text { sejam limitadas e não atendam a todas as condições para } \\
\text { a generalização das conclusões. Mesmo assim, terão } \\
\text { grande utilidade como referência para outros estudos. }\end{array}$ \\
\hline $\begin{array}{l}\text { Não se conhece uma forma de determinação experi- } \\
\text { mental direta ou indireta da rigidez axial ou de um } \\
\text { "módulo de elasticidade" que se refira a um bloco } \\
\text { maciço equivalente. }\end{array}$ & $\begin{array}{l}\text { Efetuar estudos prévios e desenvolver uma forma de } \\
\text { determinação da rigidez axial de um bloco isolado de } \\
\text { concreto, aferindo-se modelos teóricos com resultados } \\
\text { experimentais. }\end{array}$ & $\begin{array}{l}\text { Algum tipo de limitação poderá ser introduzido, tendo em } \\
\text { vista a interação de muitas variáveis, desde o processo de } \\
\text { acabamento dos blocos até as restrições do uso do } \\
\text { Método dos Elementos Finitos (MEF). }\end{array}$ \\
\hline $\begin{array}{l}\text { Não se conhecem estudos de simulação numérica sobre } \\
\text { blocos vazados, em que se analise as tensões e as } \\
\text { deformações das placas delgadas que os compõem, em } \\
\text { função das condições de vinculação do topo e da base. }\end{array}$ & $\begin{array}{l}\text { Realizar pesquisa bibliográfica e simulações numéri- } \\
\text { cas com o Método dos Elementos Finitos (MEF) so- } \\
\text { bre blocos isolados ensaiados à compressão. }\end{array}$ & $\begin{array}{l}\text { As simulações numéricas podem ficar limitadas ao estudo } \\
\text { de casos mais simples, com análise linear, tendo em vista } \\
\text { o prazo curto e as dificuldades inerentes à aplicação do } \\
\text { MEF. }\end{array}$ \\
\hline $\begin{array}{l}\text { As dimensões da camada de argamassa de assenta- } \\
\text { mento e suas propriedades de deformação longitudinal e } \\
\text { transversal influem no comportamento estrutural e no } \\
\text { modo de ruptura dos blocos, prismas e paredes. }\end{array}$ & $\begin{array}{l}\text { Realizar pesquisa bibliográfica e eventuais simulações } \\
\text { numéricas e experimentais. }\end{array}$ & $\begin{array}{l}\text { O estudo mais detalhado de deformabilidade de camadas } \\
\text { de pequena espessura pode ser uma tarefa árdua, } \\
\text { especialmente por envolver a aplicação de elementos de } \\
\text { contato pelo MEF. }\end{array}$ \\
\hline $\begin{array}{l}\text { Prismas e paredes são elementos estruturais de com- } \\
\text { ponentes mistos (blocos e argamassa de assentamento). } \\
\text { Estudos prévios demonstraram que análises } \\
\text { simplificadas por meio de simulação de componentes } \\
\text { em série podem oferecer previsões satisfatórias do seu } \\
\text { comportamento estrutural no regime elástico. }\end{array}$ & $\begin{array}{l}\text { Realizar simulações numéricas e experimentais sobre } \\
\text { prismas e paredes, no sentido de estabelecer } \\
\text { correlações teóricas entre seu comportamento } \\
\text { estrutural e as propriedades de resistência e de } \\
\text { deformação dos blocos e das argamassas de } \\
\text { assentamento. }\end{array}$ & $\begin{array}{l}\text { O estudo de paredes e prismas poderá ser limitado ou } \\
\text { mesmo suprimido do programa de Mestrado, em função } \\
\text { do volume de trabalho anterior sobre os blocos isolados, } \\
\text { o qual deverá ser prioritariamente detalhado. }\end{array}$ \\
\hline $\begin{array}{l}\text { Diversos outros fatores relacionados à prática corrente, } \\
\text { como condições de produção e controle da qualidade } \\
\text { dos blocos, variabilidade nas propriedades da argamassa } \\
\text { de assentamento durante a própria execução da parede, } \\
\text { condições reais de cura, etc., influem no } \\
\text { comportamento estrutural dos blocos, prismas e } \\
\text { paredes. }\end{array}$ & $\begin{array}{l}\text { O alvo principal desta pesquisa é a identificação e a } \\
\text { quantificação dos fenômenos estruturais inerentes ao } \\
\text { comportamento de blocos isolados, prismas e paredes, } \\
\text { e suas correlações com os principais parâmetros de } \\
\text { resistência e deformabilidade dos blocos e argamassas } \\
\text { de assentamento. Não é objetivo analisar variáveis de } \\
\text { produção e construção. }\end{array}$ & $\begin{array}{l}\text { A maior parte das variáveis relacionadas à produção de } \\
\text { blocos e à execução de paredes e prismas deverá ser } \\
\text { isolada. A pesquisa deverá limitar-se ao estudo do } \\
\text { comportamento estrutural dos blocos, prismas e paredes } \\
\text { (na medida do possível), correlacionando-o com os } \\
\text { parâmetros de resistência e deformabilidade dos blocos e } \\
\text { argamassas de assentamento. }\end{array}$ \\
\hline
\end{tabular}




\subsection{Estrutura da Dissertação}

No Capítulo 2 são apresentados os conceitos básicos relativos à Alvenaria Estrutural e discutidos os principais fatores que interferem ma resistência à compressão dos elementos de alvenaria. Discutem-se os resultados obtidos por diversas pesquisas, as quais buscam identificar as propriedades mecânicas do material que compõe o bloco.

A metodologia utilizada nos ensaios de blocos, prismas e corpos-de-prova é relatada no Capítulo 3, o qual também apresenta a descrição do comportamento desses elementos quando submetidos à compressão axial e à tração indireta.

O Capítulo 4 contém os resultados das análises experimentais, divididos em grupo de resistência para cada elemento ensaiado. Apresentam-se os resultados da resistência à compressão e à tração dos elementos e detalha-se o comportamento dos blocos vazados de concreto segundo suas curvas de deformação.

Realiza-se, no Capítulo 5, a análise teórica dos blocos e prismas quando submetidos à compressão axial, comparando-se dois modelos de ensaio de blocos isolados e detalhando-se a distribuição de tensões nesses elementos. Apresentam-se ainda uma forma de previsão da capacidade resistente e da deformabilidade do bloco vazado de concreto.

No Capítulo 6 são apresentadas as conclusões, baseadas na revisão bibliográfica efetivada e nas análises dos capítulos 4 e 5. Sugerem-se propostas para futuros trabalhos. 


\section{REVISÃO BIBLIOGRÁFICA}

Apresentam-se os conceitos básicos da Alvenaria Estrutural, fazendo um breve relato sobre a produção e normalização dos blocos de concreto e as propriedades básicas das argamassas. Discutem-se os resultados obtidos em pesquisas que analisam os fatores influentes na resistência à compressão dos elementos de alvenaria. Detalham-se as correlações obtidas entre as propriedades mecânicas dos blocos e do seu material constituinte. Descreve-se ainda, o comportamento dos elementos de alvenaria sob compressão e a obtenção de dados sobre sua deformabilidade.

\subsection{Blocos de concreto}

As unidades de alvenaria são disponíveis na forma de tijolos e blocos, produzidas com argila, concreto ou silicato de cálcio. As unidades de concreto são as mais utilizadas no Brasil, seguidas pelas unidades cerâmicas e as silico-calcárias. Os tijolos e os blocos são produzidos em muitas formas (sólidos, perfurados e vazados) e dimensões. De acordo com Hendry (2001), os tijolos são tipicamente de 102 x 65 x 215 $\mathrm{mm}$ (largura $\mathrm{x}$ altura $\mathrm{x}$ comprimento) ${ }^{1}$, enquanto os blocos são disponíveis em comprimentos de $400 \mathrm{~mm}$ a $600 \mathrm{~mm}$, alturas de $150 \mathrm{~mm}$ a $300 \mathrm{~mm}$ e larguras entre 60 mm e 250 mm. Já Medeiros (1993), após pesquisar diversas definições com relação às dimensões dos blocos de concreto, sugere que estes sejam definidos como as unidades com dimensões superiores a 120 x 55 x $250 \mathrm{~mm}$, constituídos pela mistura homogênea e adequadamente proporcionada, de cimento Portland, agregado miúdo e graúdo, conformada por vib ração e prensagem.

\footnotetext{
1 Neste texto, as dimensões das unidades de alvenaria - blocos e tijolos - são definidas por largura $\mathrm{x}$ altura x comprimento, sempre que não houver ressalva.
} 
Foi nos Estados Unidos que, no final do século XIX, surgiram os blocos de concreto vazados. Conforme relata a ABCP (2000a), foi lá também que o uso da alvenaria com blocos de concreto atingiu seu maior desenvolvimento, tendo rápido crescimento ainda na Europa, particularmente na França, Inglaterra e Alemanha. Devido a esse pioneirismo, foi natural o desenvolvimento, nos Estados Unidos e na Europa, das primeiras pesquisas e processos construtivos racionalizados, sendo hoje essa influência refletida em diversas normas.

No Brasil, a chegada da primeira máquina para produção dos blocos de concreto, importada dos Estados Unidos na década de 1950, marca o início da história desses componentes.

Medeiros (1993) estima que mais de dois terços de toda alvenaria feita nos Estados Unidos seja de blocos de concreto, podendo-se dizer que eles são utilizados em praticamente todos os lugares do mundo.

Andolfato et al. (2002) definem que, dentre os materiais empregados para a produção das unidades de alvenaria, sobressai o emprego dos blocos de concreto com função estrutural, permitindo o emprego da técnica de coordenação modular como fator essencial na sistematização e programação do projeto como um todo. Justamente por serem modulares, os blocos tornam a construção mais racional, resultando em economia tanto para os empreendedores como para o consumidor final (ABCP, 2000a).

A implementação da racionalização desse sistema construtivo começa na produção e utilização de seu menor componente. Se bem planejado e projetado, sem dúvida, encontrar-se-ão as vantagens oferecidas.

$\mathrm{Na}$ fabricação dos blocos de concreto utiliza-se um concreto com consistência de terra úmida (concreto seco) e não um concreto plástico, como os convencionalmente utilizados nas estruturas de concreto armado. Conforme Tango (1994), no concreto plástico praticamente a pasta (cimento mais água) ocupa todos os espaços deixados pelos agregados, enquanto que no concreto para blocos existe a presença de ar em um volume significativo na mistura. Ressalta ainda que isso faz com que o concreto para blocos não siga o princípio consagrado para o concreto plástico, de que é preciso menos água para aumentar a resistência.

A ABCP (2000a) alerta que a resistência dos blocos, além de depender de uma boa dosagem, é diretamente proporcional à energia de compactação utilizada em sua fabricação, sendo a eficiência da vibro-prensa a responsável direta pela qualidade final dos pré-moldados. Em contrapartida, o concreto plástico tem como particularidade que 
a sua resistência pode ser medida diretamente em corpos-de-prova de concreto, sendo menos influenciada pelo tipo de equipamento ou forma da produção do pré-moldado.

Encontra-se dificuldade no método produtivo convencional dos blocos de concreto de se coletar corpos-de-prova diretamente do material utilizado na sua produção para controle de qualidade e identificação das propriedades mecânicas do produto final. É evidente que se pode utilizar um bloco isolado como um corpo-deprova, porém, acredita-se que um melhor conhecimento das propriedades do material contribuiria para um melhor entendimento do comportamento estrutural dos elementos de alvenaria.

Medeiros (1993) define que os principais insumos empregados na fabricação dos blocos de concreto são:

- para a fração grossa: pedra britada de graduação zero (pedrisco) e pedregulho natural;

- para a fração fina: areia natural e areia artificial;

- aglomerante: cimento Portland;

- aditivos: redutores de água e plastificantes;

- água.

Prossegue relatando que, como regra geral, materiais adequados para a produção de concreto convencional são adequados para a produção de blocos, embora várias características sejam particularizadas para o segundo caso, notadamente aquelas que dizem respeito à granulometria.

A NBR 7217 (1987) estabelece os limites granulométricos para as areias e pedriscos utilizados na confecção do concreto. Prescreve que os grãos das areias devem possuir diâmetro entre $0,15 \mathrm{~mm} \mathrm{e} 6,3 \mathrm{~mm}$, enquanto os pedriscos, grãos entre 2,4 mm e 9,5 mm. As areias naturais usadas para a produção de blocos devem possuir grãos duros, compactos, duráveis e limpos, não contendo substâncias que possam afetar a hidratação e endurecimento do cimento. Esses agregados necessitam ser lavados para a retirada dos excessos de material fino e da matéria orgânica. Os agregados graúdos empregados na produção de blocos de concreto devem ser, de acordo com a NBR 7211 (1983), originados da britagem de rochas duras (calcários dolomíticos, rochas basálticas e graníticas) que não possuam sinais de materiais friáveis como o arenito e micas. 
A NBR 6136 (1994) limita à zona de graduação zero a permissão para uso de agregado na produção de blocos, uma vez que ele normalmente não pode possuir grãos com diâmetro superior à metade da espessura da menor parede do bloco.

As etapas de produção dos blocos de concreto são:

- proporcionamento e mistura dos materiais;

- moldagem do material, por meio de vibração e prensagem;

- cura, iniciada após desmoldagem dos blocos, e de grande importância para obtenção das características desejáveis, podendo ser cura natural, cura à vapor à baixa pressão ou cura em autoclaves.

Ainda relacionado com a produção dos blocos de concreto, após um rigoroso estudo de dosagem com cinco diferentes traços e posteriores análises experimentais, Andolfato et al. (2002) concluem que:

- a quantidade de cimento tem forte influência na rigidez dos blocos e pequena influência na sua resistência à compressão;

- a relação água-cimento não afeta significativamente a resistência à compressão dos blocos, como se poderia supor em analogia ao concreto plástico;

- o grau de compacidade, que está relacionado com a quantidade de água da mistura, tem grande influência na resistência final dos blocos;

- é fundamental a determinação da umidade ótima para cada traço que apresente diferentes relações entre areia, pedrisco e cimento.

De acordo com Drysdale et al. (1994), NBR 6136 (1994), Ramalho e Corrêa (2003) e Sahlin (1971), o bloco vazado de concreto é definido como o elemento de alvenaria cuja área líquida (descontadas as áreas máximas dos vazios) é igual ou inferior a 75\% da área bruta (área sem descontos das áreas dos vazios).

As amostras submetidas a ensaios segundo a NBR 7184 (1992), a NBR 12117 (1991) e a NBR 12118 (1991) devem atender a requisitos relativos à resistência à compressão característica $\mathrm{f}_{\mathrm{bk}}$. As classes de resistência característica admitidas pela norma variam de $6 \mathrm{MPa}$ a $16 \mathrm{MPa}$, sendo que a classe de resistência de 4,5 MPa só tem seu uso admitido utilizando-se os blocos acima do nível do solo e com paredes revestidas com argamassa. 
A NBR 6136 (1994) define ainda que os blocos devem atender às dimensões padronizadas na Tabela 2.1, permitindo-se tolerância de $\pm 2 \mathrm{~mm}$ para a largura e \pm 3 mm para a altura e comprimento; a espessura mínima em qualquer uma das paredes do bloco deve satisfazer às indicações da Tabela 2.2. A menor dimensão do furo, atendidas as demais exigências da norma, não deve ser inferior a $8 \mathrm{~cm}$, para o bloco de $14 \mathrm{~cm}$ de largura, e a $12 \mathrm{~cm}$, para o bloco de $19 \mathrm{~cm}$ de largura, possuindo mísulas de transição com raio mínimo de $2 \mathrm{~cm}$ entre as paredes longitudinais e transversais.

Tabela 2.1 - Dimensões padronizadas conforme a NBR 6136 (1994).

\begin{tabular}{ccccc}
\hline \multirow{2}{*}{$\begin{array}{c}\text { Dimensões } \\
\text { nominais (cm) }\end{array}$} & Designação & \multicolumn{2}{c}{ Dimensões padronizadas (mm) } \\
& Largura & Altura & Comprimento \\
\hline $20 \times 20$ × 40 & M-20 & 190 & 190 & 390 \\
$20 \times 20 \times 20$ & & 190 & 190 & 190 \\
$15 \times 20 \times 40$ & & 140 & 190 & 390 \\
$15 \times 20 \times 20$ & M-15 & 140 & 190 & 190 \\
\hline
\end{tabular}

Tabela 2.2 - Espessura mínima das paredes dos blocos conforme a NBR 6136 (1994).

\begin{tabular}{|c|c|c|c|}
\hline \multirow[b]{2}{*}{ Designação } & \multirow[b]{2}{*}{$\begin{array}{l}\text { Paredes longitudinais }{ }^{(\mathrm{A})} \\
(\mathrm{mm})\end{array}$} & \multicolumn{2}{|c|}{ Paredes transversais } \\
\hline & & $\begin{array}{l}\text { Paredes } \\
\qquad(\mathrm{mm})\end{array}$ & $\begin{array}{c}\text { Espessura } \\
\text { equivalente }^{(\mathrm{B})} \\
(\mathrm{mm})\end{array}$ \\
\hline M-15 & 25 & 25 & 188 \\
\hline M-20 & 32 & 25 & 188 \\
\hline
\end{tabular}

\subsection{Argamassa de assentamento}

A argamassa de assentamento tem como função principal unir as unidades de alvenaria e distribuir as tensões uniformemente entre elas. Apesar de representar uma pequena porcentagem do total da alvenaria, ela influencia significativamente o seu comportamento, inclusive no mecanismo de ruptura. Geralmente, a argamassa é constituída de cimento Portland, cal ou plastificante e areia. A cal proporciona plasticidade (o que permite maiores deformações sem fissuração) e capacidade de retenção de água (o que resulta em uma melhor aderência).

Solórzano (1994) explica a importância de materiais como a cal, que, incorporados nas argamassas, diminuem a sua rigidez e permitem a acomodação das 
movimentações intrínsecas da alvenaria, além de produzirem argamassas mais econômicas e otimizarem as propriedades do produto final. As argamassas não plásticas e não trabalháveis não preenchem todos os vazios e podem fissurar quando endurecidas devido à retração hidráulica ou movimentação térmica dos componentes. Barbosa (2002) atribui ainda à capacidade de deformação a ajuda na distribuição de esforços e na vedação, pois a argamassa pode absorver parte desses esforços e dissipá-los sob forma de microfissuras não prejudiciais à estanqueidade e à resistência da parede. Justifica ainda que esse mecanismo não acontece com argamassas muito rígidas, ou seja, com alto módulo de deformação, pois os esforços atuantes são dissipados por meio de macrofissuras, provocando infiltrações e perda de aderência.

Tais propriedades não são facilmente alcançadas, pois as propriedades do bloco, principalmente a sucção, também influenciam nas propriedades da argamassa. De acordo com Sahlin (1971), a relação entre a sucção das unidades de alvenaria e a retenção de água das unidades pode ser tal que uma camada pouco espessa de argamassa esteja próxima de secar totalmente em um curto intervalo de tempo. Nesse caso, a aderência entre a argamassa e o bloco será prejudicada e fissuras aparecerão entre as unidades e a argamassa endurecida.

Como características no estado endurecido, Drysdale et al. (1994), Hendry (2001), Mondardo et al. (1994) e Sabbatini (1984) explicam que a argamassa tem que ser suficientemente eficiente, no sentido de apresentar resistência à compressão e à aderência satisfatória, não ter retração excessiva (que reduz a resistência da alvenaria à penetração de chuvas e causa fissuração nas unidades), além de ser durável. Deverá também ser capaz de acomodar movimentações resultantes da fluência ou efeitos térmicos sem fissurar.

No estado plástico, é necessário que a argamassa possua trabalhabilidade suficiente para que não comprometa o assentamento e a retenção de água.

Segundo Sabbatini (1984), dois conceitos fundamentais são necessários para encontrar a argamassa ideal:

- a argamassa adequada é aquela que melhor compatibiliza as capacidades de aderência com a de absorver deformações;

- a avaliação correta da capacidade das argamassas só é possível se forem ensaiados corpos-de-prova bloco-argamassa. 


\subsection{Fatores que interferem na resistência à compressão dos elementos de alvenaria}

Diversos fatores afetam os valores da resistência das unidades, prismas e paredes de alvenaria. Hendry (1998) apresenta uma série que exercem comprovadamente influência na resistência à compressão da alvenaria; são eles: geometria da unidade, resistência da unidade, espessura da junta de argamassa, resistência da argamassa, deformação característica da argamassa, sucção das unidades e retenção de água da argamassa.

Medeiros (1993) considera que nem todos os fatores exercem a mesma influência, e, portanto, a avaliação dos efeitos de cada um na resistência final da alvenaria deve ser considerada sob o fenômeno que influencia o mecanismo de ruptura da alvenaria submetida à compressão.

Já a análise de Sabbatini (1984) sobre o mecanismo de ruptura da alvenaria na compressão identifica como fatores influentes a resistência da junta de argamassa, a resistência de aderência do conjunto (afetada pela sucção inicial dos elementos, qualidade da mão-de-obra e condições de cura), as características reológicas da unidade e da junta de argamassa, a espessura e a disposição das juntas e o formato, dimensões, existência de vazios e tolerâncias dimensionais das unidades de alvenaria. Além disso, cita que outros fatores influentes ainda podem surgir devido à falta de padronização dos ensaios e corpos-de-prova, sendo que estes aparecem durante o experimento, fornecendo resultados discrepantes. Como exemplo são citados a geometria dos corposde-prova, o material de capeamento do corpo-de-prova, as condições de confinamento impostas pela máquina de ensaio ao corpo-de-prova e a velocidade do carregamento.

Os resultados divergentes encontrados nos ensaios de uma determinada espécie são, conforme Sahlin (1971), atribuídos à não consideração de alguns fatores, como a forte influência do capeamento, os ensaios com placas distintas e os diversos métodos de ensaio de resistência à compressão da unidade e alvenaria, ocasionando assim a análise dos resultados e estimativas equivocadas. Portanto, o autor considera que os métodos de ensaio devam ser semelhantes, seguindo as prescrições mínimas de rigidez do topo e da base, do material de capeamento das unidades e que os ensaios de paredes sejam bem definidos e controlados; só assim podem ser comparados os resultados obtidos em diferentes laboratórios.

A seguir, discutem-se alguns desses fatores intervenientes. 


\subsubsection{Geometria dos elementos}

A resistência à compressão, muitas vezes referenciada por resistência "aparente", depende, segundo Hendry (2001), das dimensões e do tipo da unidade (se vazadas, perfuradas ou sólidas). A resistência efetiva da unidade é aumentada quando ensaiada à compressão axial, devido à influência do efeito de confinamento provocado pela restrição imposta pelas placas da máquina de ensaios.

Como exemplo, Hendry (1998) compara um tijolo e um bloco constituídos pelo mesmo material e ensaiados de forma semelhante. Afirma que os dois elementos terão resistências diferentes, tendo o tijolo uma configuração mais resistente obtida pela atuação do "efeito das placas" (platen effect), justificando que as dimensões externas influenciam diretamente o comportamento da alvenaria (e da unidade) quando solicitada à compressão. Com a restrição provocada pelas placas, tensões de compressão transversal confinantes imprimirão um estado triaxial de compressão ao bloco. Medeiros (1993) e Hendry (2001) citam que Render (1986) ${ }^{2}$ explica a variação de resistência por meio da definição do aspect ratio, ou seja, a relação entre a altura e a largura dos blocos. Em ensaios realizados pelo autor, a resistência dos blocos de altura de $100 \mathrm{~mm}$ foi cerca de $43 \%$ a $60 \%$ maior que a resistência dos de altura entre 150 e 200 mm, devido à variação da altura dos elementos, pois o efeito do confinamento atua em uma zona de influência - ao longo da altura da unidade - proporcionalmente maior. Com base nesses resultados, conclui que ao se variar apenas a altura, e manter constante as demais variáveis de um bloco, serão encontradas unidades menos resistentes quanto maior for sua relação $\mathrm{h} / \mathrm{t}$.

O gráfico apresentado na Figura 2.1 foi obtido por meio de ensaios realizados por Page $(1984)^{3}$, e citados Hendry (1998), em que são comparados os valores de resistência de unidades silico-calcárias comparadas com a relação altura/largura. Notase que um maior declínio na relação entre as resistências ocorre mo intervalo de relação h/t entre aproximadamente 0,2 e 1,2. A partir daí o declínio continua a ocorrer, porém com menor intensidade, ficando claro que quanto menor for a relação entre $\mathrm{h}$ e t, maiores serão os valores da resistência "aparente".

2 RENDER, S. (1986). The compressive strength of masonry walls built using blocks laid flat. In: PRATICAL DESIGN OF MASONRY STRUCTURES, 1986, London. Proceedings. Thomas Telford, p.319-36.

3 PAGE, A.W. (1984). A study of the influence of the brick size on the compressive strength of calciumsilicate masonry. University of Newcastle. Engineering Bulletin CE 13. 


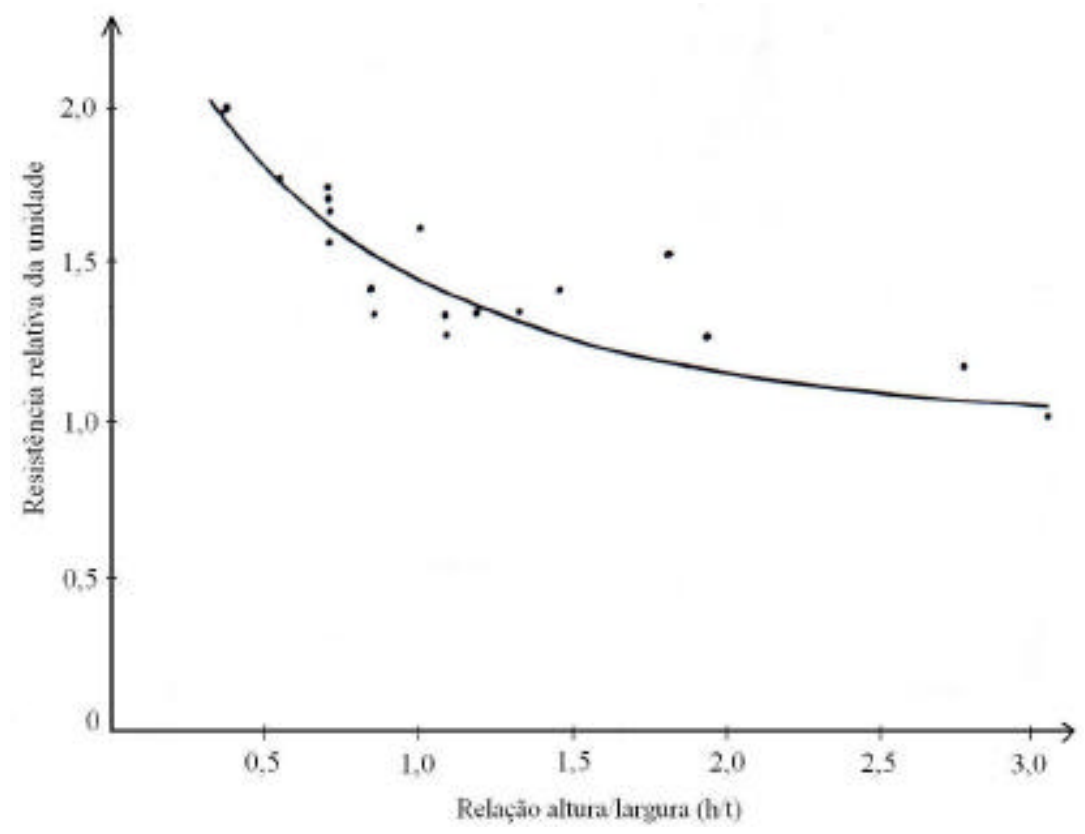

Figura 2.1 - Relação entre a resistência da unidade sob ação do confinamento das placas e unidades sem esse efeito versus relação altura/largura $(\mathrm{h} / \mathrm{t})$, adaptada de Page $(1984)^{3}$ apud Hendry (1998).

O Eurocódigo 6 (1995) define a resistência normalizada à compressão de uma unidade como sendo a resistência obtida por analogia ao ensaio com uma unidade padrão, em forma de cubo de $100 \mathrm{~mm}$ de aresta. Essa resistência é determinada por meio de ensaios à compressão e multiplicada pelo fator d que caracteriza as unidades de diferentes dimensões. Tal fator é obtido em função da altura e da menor dimensão da unidade ensaiada. Hendry (1998) afirma que a Equação (2.1) leva a valores muito similares.

$$
\mathrm{d}=(\mathrm{h} / \sqrt{\mathrm{A}})^{0,37}
$$

h é a altura da unidade;

A é a área carregada.

A Equação (2.2), sugerida pelo referido código $^{4}$, define a resistência característica à compressão da alvenaria $\left(\mathrm{f}_{\mathrm{b}}\right)$; a resistência normalizada é determinada em função de d.

$$
\mathrm{f}_{\mathrm{k}}=\mathrm{K}\left(\mathrm{f}_{\mathrm{b}}\right)^{0,65}\left(\mathrm{f}_{\mathrm{m}}\right)^{0,25}
$$

K é a constante que depende do tipo da alvenaria;

4 De acordo com Lourenço (2003), o Eurocode 6 utiliza uma nova formulação, apresentada a seguir: $\mathrm{f}_{\mathrm{k}}=\mathrm{K}\left(\mathrm{f}_{\mathrm{b}}\right)^{0,7}\left(\mathrm{f}_{\mathrm{a}}\right)^{0,3}$. 
$\mathrm{f}_{\mathrm{b}}$ é a resistência normalizada à compressão da unidade, em MPa;

$\mathrm{f}_{\mathrm{m}}$ é a resistência média à compressão da argamassa, em MPa.

Os valores de $\mathrm{K}$ variam de 0,4 a 0,6 dependendo do tipo das unidades (material constituinte, volume de vazios e espessura das paredes) e das formas com que estão dispostas na parede de alvenaria.

Devido à configuração da unidade vazada, Rizzatti (2003) enfatiza que a geometria e as dimensões dos vazios podem acarretar grandes concentrações de tensões, alterando a eficiência da alvenaria e a sua forma de ruína. Por meio de simulações numéricas, utilizando o Método dos Elementos Finitos, com quatro geometrias distintas de blocos (dois com os vazios circulares, um com retangular e outro com retangular e septo central duplo), o autor conclui não haver concentrações de tensões significativas que influenciem no desempenho do bloco e que as diferenças geométricas não influenciaram significativamente a resistência do componente. Cabe ressaltar que as dimensões externas dos quatro tipos de blocos são iguais, alterando-se apenas sua geometria interna.

Medeiros (1993) relata que Holm $(1976)^{5}$ questiona as exigências mínimas apresentadas pela norma americana, hoje ASTM C 90 (1991), para a espessura dos septos transversais dos blocos estruturais. A base desse questionamento é uma série de experiências de laboratório, em que ficou demonstrado que os septos transversais especificados na norma americana eram muito esbeltos para distribuírem adequadamente as cargas aplicadas diretamente sobre as paredes longitudinais da face de assentamento. Com base nessa experiência foi sugerido que estudos sobre a resistência à tração e à rigidez dos blocos fossem conduzidos para explicar o tipo de ruptura observado.

Conforme Medeiros (1993), em estudos desenvolvidos pelo Centro de Pesquisas e Desenvolvimento em Construção Civil ${ }^{6}$, em 1991, analisou-se qual a seção transversal ótima para um determinado bloco de concreto, levando em conta o fator de eficiência da alvenaria (relação entre a resistência da parede e do bloco). Ensaiaram-se oito modelos diferentes de seções transversais, de blocos com dimensões nominais $15 \mathrm{x}$ 20 x $30 \mathrm{~cm}$ duplamente vazados. Paralelamente realizou-se análise numérica

\footnotetext{
5 HOLM, T.A. (1976). Block concrete is a structural material. Journal of Testing and Evaluation, v.4, n.4, p.293-99, july.

${ }^{6}$ CENTRO DE PESQUISAS E DESENVOLVIMENTO EM CONSTRUÇÃO CIVIL (1991). Manual do processo construtivo POLI/ENCOL: blocos e pré-moldados. São Paulo, Escola Politécnica da Universidade de São Paulo/ENCOL . Relatório Técnico R5-26/91.
} 
empregando o Método dos Elementos Finitos. As principais conclusões estão listadas a seguir:

- existe uma concentração de tensões de tração primariamente originada no septo transversal dos blocos, principalmente no septo transversal central, devendo-se, portanto, aumentar a espessura desses septos quando se deseja implementar a resistência à compressão dos blocos e do elemento de alvenaria com eles construídos;

- aumentando-se os raios de concordância entre os septos podem-se diminuir os efeitos de concentração de tensão verificados nesses pontos;

- a utilização de mísulas constitui uma alternativa para aumentar a rigidez da ligação entre os septos transversais e as paredes longitudinais dos blocos;

- os blocos com septos transversais de maior espessura apresentaram maior resistência à compressão, mesmo sem a presença de mísulas ou grandes raios de curvatura.

Em relação aos prismas, Drysdale e Hamid (1979) afirmam que os resultados obtidos por meio de ensaios com elementos de dois blocos são de difícil correlação com o comportamento da parede de alvenaria. Isso ocorre por que o confinamento do topo e base do prisma faz com que a sua resistência seja aumentada e o modo de ruína seja alterado, prejudicando a forma normal de ruptura dos prismas (tração nas unidades segundo planos paralelos à aplicação de carga) e aumentando a carga necessária para rompê-lo, passando a ruína a ocorrer por cisalhamento. Nos ensaios realizados com prismas de três blocos, constataram que o modo de ruína permaneceu constante, sendo caracterizado pela fissuração por tração nos blocos centrais, coincidindo, portanto, com o modo de ruína das paredes de alvenaria. Por meio de simulações numéricas, La Rovere e Rodrigues (1997) e Page e Kleeman (1991) obtiveram as mesmas conclusões.

Segundo Maurenbrecher (1980), com o aumento da razão altura/largura (h/t), o confinamento passa a ter uma influência cada vez menor nas resistências obtidas nos ensaios, como é relatado por Page $(1984)^{3}$ em ensaios com blocos. Cita ainda que, no caso de prismas de blocos vazados de concreto, a resistência é mais influenciada pela esbeltez das paredes longitudinais e septos transversais do que pelos valores de $\mathrm{h} / \mathrm{t}$.

Entretanto, devido ao processo de fabricação dos blocos, para que se facilite a desforma por extrusão, a geometria dos septos (tanto transversais quanto longitudinais) 
sofre alterações. As paredes dos blocos têm uma inclinação ao longo da altura na parte interna dos blocos, resultando em uma diferença de espessura (da ordem de $3 \mathrm{~mm}$ a 6 $\mathrm{mm}$ ) quando medida no topo e na base. Estudos com blocos vazados de concreto mostram que a inclinação dos septos também influencia na resistência dos prismas.

Segundo Calçada (1998), a diferença de dimensões gera tensões de tração no topo da unidade inferior, que podem ser maiores que aquelas geradas pela diferença no coeficiente de Poisson entre os materiais constituintes. Shrive (1982) também considera que essa diferença provoca uma concentração de tração nas regiões próximas à face de menor área, aumentando ainda mais as características anisotrópicas das paredes na direção perpendicular às juntas horizontais de argamassa (direção de aplicação do carregamento à compressão).

Por meio de simulações numéricas, Steil e Prudêncio Júnior (2002) identificam que além das tensões geradas pela diferença de deformabilidade entre o bloco e a argamassa, a geometria dos septos também influenciou no aparecimento de tensões de tração nos blocos, sendo que nos prismas constituídos por blocos que possuíam a menor diferença de seção entre o topo e a base, ocorreram as menores tensões de tração, resultando em um maior fator de eficiência. Barbosa et al. (2003), também por meio de simulações numéricas (fundamentadas no Método dos Elementos Finitos), observaram que a variação da seção geométrica influencia na distribuição das tensões e, posteriormente, na resistência dos prismas de blocos vazados de concreto, identificandose uma maior intensidade de tensões de tração nos blocos com septos de espessura variável.

A NBR 10837 (1989) prevê a resistência à compressão axial das paredes por meio de ensaios de prismas com os mesmos materiais da construção, entretanto, Steil e Prudêncio Júnior (2002) consideram que é comum a utilização de tabelas e equações para estimativa da resistência da alvenaria, o que pode levar a valores não condizentes com o real desempenho da alvenaria já que, nesse caso, as resistências à compressão do bloco e da argamassa são singularmente consideradas.

\subsubsection{Resistência das unidades}

A resistência à compressão da unidade é o principal parâmetro de projeto da parede de alvenaria, calculada comumente em relação à área bruta. Drysdale et al. (1994) afirmam que as demais propriedades das unidades de alvenaria também são 
baseadas nessa área, desprezando os vazios incorporados às unidades. Entretanto, citam que com o refinamento dos métodos de projeto passourse a usar a área líquida para cálculo da esbeltez e da resistência à flexão.

Apesar do comportamento do bloco se distanciar em relação às paredes, tanto na deformação quanto na ruptura, os ensaios normalizados servem para dar uma idéia de grandeza e proporcionalidade da resistência desses componentes e das características dos materiais, complementa Medeiros (1993).

O aumento da resistência dos blocos acarreta aumento na resistência da alvenaria. Contudo, a proporção desse aumento diminui com o aumento da resistência dos blocos em conseqüência, segundo Juste (2001), devido ao maior diferencial existente entre as unidades e as juntas de argamassa. Drysdale et al. (1994) atribuem essa relação ao aumento da resistência à tração do bloco, que cresce com o aumento da sua resistência à compressão.

Hendry (1998) considera que a resistência da alvenaria é aproximadamente proporcional à raiz quadrada da resistência do bloco. Já Sahlin (1971), considera que o fator de eficiência, $\mathrm{f}_{\mathrm{alv}} / \mathrm{f}_{\mathrm{b}}$, varia entre $25 \%$ e $50 \%$, dependendo do tipo da parede e do coeficiente de esbeltez. No Brasil, Ramalho e Corrêa (2003) identificam a eficiência variando entre 0,40 e 0,60 para blocos vazados de concreto não-grauteados e com argamassas usuais. Complementam que para os prismas esse intervalo se amplia, variando de 0,5 a 0,9 .

Drysdale et al. (1994) relatam que Senbu e Baba $(1985)^{7}$ sugerem, para unidades vazadas, ensaios com partes retiradas do bloco (pequenos prismas extraídos das paredes longitudinais) que resultam em dados mais condizentes das propriedades à compressão.

Medeiros (1993) destaca ainda a importância da resistência à tração dos blocos, ressaltando que as principais limitações estruturais da alvenaria devem-se às tensões de tração, apesar dos principais critérios de projeto e classificação dos blocos de concreto levarem em consideração a sua resistência à compressão. Drysdale et al. (1994) mencionam que o entendimento da resistência à tração da alvenaria pode ser importante para o conhecimento dos mecanismos de falha. Enfatizam que a resistência à compressão e à tração dos blocos têm papel significativo na resistência da alvenaria, citando que ensaios com grupo de blocos de mesma resis tência apresentaram dispersões

7 SENBU, O.; BABA, A. (1985). Mechanical properties of masonry units. In: JOINT TECHNICAL COORDINATING, 1., 1985, Tokyo. Proceedings. p.3.1/1-3.1/19. 
significativas quando utilizadas juntas de argamassa nos septos transversais dos blocos, indicando a possibilidade da ruptura estar relacionada com as diferenças de resistência à tração dos blocos.

Shrive (1982) relata que as tensões de tração concentram-se nos septos dos blocos e são diretamente responsáveis pela ruptura da alvenaria carregada axialmente à compressão. De acordo com as teorias de ruína, o bloco rompe em virtude das tensões de tração - provocadas pela diferença entre as propriedades do material do bloco e argamassa - após o início da fissuração. Entretanto, notam-se poucos estudos com relação a essa propriedade apesar da grande importância que ela apresenta. Assim, quanto maior a resistência à tração do bloco, maior é a resistência da alvenaria.

Drysdale et al. (1994) admitem que os ensaios de resistência à tração podem ser realizados com a unidade ou com pedaços retirados das unidades; citam ainda o ensaio de resistência à flexão baseado na teoria elástica linear e o ensaio de tração indireta (splitting test), que permitem obter uma medida comparativa com a resistência à tração. Esses ensaios levam a resultados em torno de $10 \%$ da resistência à compressão das unidades.

Cheema e Klingner (1986) citam, baseados em ensaios de resistência à tração, que é razoável a adoção da Equação (2.3).

$$
\mathrm{f}_{\mathrm{tb}}=0,41 \sqrt{\mathrm{f}_{\mathrm{b}}}
$$

$\mathrm{f}_{\mathrm{tb}}$ é a resistência à tração do bloco de concreto em MPa;

$\mathrm{f}_{\mathrm{b}}$ é a resistência à compressão do bloco de concreto em MPa.

\subsubsection{Espessura da junta de argamassa}

A espessura das juntas de argamassa é de fundamental importância no estabelecimento da resistência à compressão das paredes de alvenaria. Sua varia ção para mais ou para menos altera a resistência dos elementos. De acordo com Sabbatini (1984) e Sahlin (1971) essa variação ocorre em virtude da junta de argamassa ser a parte “frágil” da alvenaria, sendo assim, as resistências mais altas são obtidas com juntas menos espessas e relações mais baixas de espessura de junta e altura do bloco. Contudo, Ramalho e Corrêa (2003) explicam que a espessura não pode ser muito pequena, pois dessa forma permitiria que, por falhas de execução, os pontos das superfícies dos blocos acabassem se tocando, levando a uma alta concentração de tensões. Atribuem ainda ao 
decréscimo do confinamento, ocasionado pelo aumento da espessura da junta horizontal, a redução da resistência das paredes, tornando-se, nesse caso, a argamassa mais susceptível à ruptura. Já Sabbatini (1984) considera que com incremento da espessura da junta de argamassa ocorre um aumento de deformação relativa, aumentando seu diferencial de deformação em relação ao bloco. Essa deformação gera um aumento nas tensões internas solicitantes do bloco, implicando na diminuição da resistência da alvenaria.

Sahlin (1971) afirma que pode haver um decréscimo na resistência à compressão da alvenaria de $15 \%$ para cada $3 \mathrm{~mm}$ de aumento na espessura da junta, ocorrendo acréscimo na mesma proporção para cada $3 \mathrm{~mm}$ de diminuição de espessura da junta. Em ensaios realizados por Drysdale e Hamid (1979), o aumento da espessura da junta de argamassa de 9,5 $\mathrm{mm}$ para $19 \mathrm{~mm}$ resultou em um decréscimo na resistência do prisma de três blocos de $16 \%$.

Em ensaios de prismas realizados por Moreno Júnior e Albuquerque (2001), observou-se que a ruptura dos prismas ocorreu com a ruptura do bloco (instantes depois de iniciada a primeira fissura na face lateral do bloco) ou com a ruptura por esmagamento da junta de argamassa (instantes depois de iniciada a primeira fissura, horizontal, na junta de assentamento). Utilizaram-se 3 diferentes traços de argamassa, com resistências médias à compressão de $9 \mathrm{MPa}, 13 \mathrm{MPa}$ e $23 \mathrm{MPa}$ e blocos com resistência à compressão de $8 \mathrm{MPa}$ (em relação à área bruta). A ruptura na junta de assentamento ocorreu nos prismas com argamassas mais fracas e com juntas entre 15 $\mathrm{mm}$ e $20 \mathrm{~mm}$. Os prismas tiveram sua resistência diminuída com o aumento da espessura da junta.

Hendry (1998) enfatiza que quanto maior for a relação entre a espessura da junta de argamassa e a altura da parede de alvenaria, maior será a tendência de que a ruína da unidade seja por separação lateral. Complementa que em alguns elementos com blocos de concreto encontram-se resistências similares da argamassa e dos blocos e, nesse caso, a argamassa tenderá a reduzir as deformações laterais nos blocos, o que gera um tipo de ruína por cisalhamento em algumas linhas de fragilidade da alvenaria mais propriamente que na fissuração típica por tração vertical. 


\subsubsection{Resistência da argamassa}

A resistência à compressão da argamassa, avaliada individualmente para medir o comportamento da junta, é considerada apenas como um parâmetro indicativo, uma vez que o estado de confinamento dos corpos-de-prova não reproduz o comportamento na alvenaria (SABBATINI, 1984). Isso porque nos ensaios com corpos-de-prova padronizados, o elemento fica submetido a um estado uniaxial de tensões, diferente do estado triaxial de tensões de compressão a que ela fica sujeito na alvenaria.

$\mathrm{O}$ estado triaxial é bem mais atuante na argamassa de alvenaria de blocos sólidos, pois a região central da argamassa está totalmente confinada e distante das extremidades. Em relação a esses dois estados de tensões, Medeiros (1993) cita que um grande aumento da resistência à compressão da argamassa no ensaio uniaxial corresponde a um pequeno aumento na resistência no estado triaxial.

A argamassa, sob forma de junta, também tem sua resistência aumentada em função das condições de cura a que ela está submetida. As unidades de alvenaria tendem a absorver parte da água da argamassa em seu estado fresco, fazendo com que suas propriedades mecânicas sejam alteradas.

Com o aumento da resistência da argamassa das juntas da alvenaria, aumentase a resistência desses elementos, como conseqüência da menor deformabilidade desenvolvida, justifica Sabbatini (1984). Hendry (1998) considera que a resistência da alvenaria seja proporcional à raiz cúbica ou à raiz quarta da resistência da argamassa.

Apesar da resistência da argamassa influenciar diretamente a resistência da alvenaria, a modificação da resistência desta estrutura depende muito mais da variação do módulo de deformação da argamassa já que a ruína ocorre devido à diferença de deformações entre os elementos que a compõe. Portanto, para avaliação de um determinado traço de argamassa, deve-se estudar suas propriedades em ensaios em conjunto com os blocos. Calçada (1998) considera que variações expressivas na resistência da argamassa alteram pouco a resistência dos prismas. Entretanto, argamassas muito fracas podem provocar a ruptura da alvenaria por seu esmagamento.

Mohamad et al. (2002b) identificam na diferença das propriedades do bloco e da argamassa, especialmente no módulo de elasticidade e coeficiente de Poisson, a principal causa da diminuição da resistência da alvenaria. Ensaiando-se prismas submetidos à compressão axial, a argamassa é submetida a um estado triaxial de compressão, e o prisma a um estado biaxial de tração-compressão. Os autores 
realizaram estudos sobre o confinamento da argamassa, observando que à medida que se aumenta a tensão de confinamento lateral - simulando-se a situação da junta de argamassa nos ensaios de prismas - há um aumento na resistência da argamassa. Utilizando-se traços em quatro níveis de resistência $(5,11,25$ e $35 \mathrm{MPa})$, observaram ainda que as deformações axiais e longitudinais foram maiores para os traços mais fracos à medida que se aumentou a tensão de confinamento. Para os traços mais fortes, o módulo de deformação apresenta um sensível aumento à medida que se aumentam as tensões de confinamento. Ao contrário, para os traços mais fracos, o módulo de deformação diminui com o aumento da tensão de confinamento. Essa diminuição do módulo de elasticidade pode ser justificada, segundo Mohamad (2004), pelo alto nível de porosidade que os traços mais fracos têm devido ao fator água-cimento, ocasionando diminuição dos vazios internos da argamassa. Em todos os níveis de resistência houve diminuição significativa do coeficiente de Poisson ao se aumentarem as tensões de confinamento. As argamassas com resistências à compressão mais altas tiveram um comportamento mais frágil na ruptura, enquanto que os traços que resultaram em uma argamassa mais fraca apresentaram maior ductilidade.

Hendry (1998) comenta que a resistência à compressão da argamassa, seja ela medida em cubos ou em cilindros, não é um fator crítico. Como exemplo, cita que, se a resistência à compressão de um tijolo é de $35 \mathrm{MPa}$, com uma argamassa de resistência de $14 \mathrm{MPa}$, tem-se a resistência de uma parede de $16 \mathrm{MPa}$; já com uma argamassa de 7 MPa tem-se uma resistência de $14 \mathrm{MPa}$. Ou seja, para uma mesma resistência de tijolo, ao se diminuir a resistência da argamassa em $50 \%$ obtém-se uma resistência de parede apenas $12,5 \%$ menor.

Como uma das principais funções das juntas de argamassa é a de compensar o efeito de pequenas deformações do conjunto, nota-se a importância de que ela seja menos rígida que os blocos e, como consequiência, menos resistente. No entanto, quanto mais deformáveis forem, maiores serão as tensões de tração no bloco em virtude de sua maior expansão.

Em ensaios com prismas realizados por Mohamad et al. (2002a), ao se utilizar argamassas com traços menos resistentes à compressão do que a resis tência do bloco a ruptura dos prismas foi dúctil, ocorrendo um esfacelamento da parte externa das paredes dos blocos, inicialmente próximo às juntas e espalhando-se depois por todo o bloco. Utilizando-se argamassa com o mesmo nível de resistência à compressão do bloco, o tipo de ruptura foi essencialmente frágil no sentido da seção transversal do prisma. 
Assim, os autores concluíram que deve haver compatibilidade entre a resistência da argamassa e a do bloco, recomendando-se que a resistência à compressão da argamassa seja entre 0,70 a 1 vez a resistência à compressão do bloco na área bruta. Ramalho e Corrêa (2003) consideram que a resistência da argamassa é importante apenas quando inferior a $30 \%$ ou $40 \%$ da resistência do bloco, e ainda que em argamassas com resistência em torno de 50\% desta resistência dificilmente haverá variação significativa na resistência da parede.

\subsubsection{Capeamento}

Os capeamentos são finas camadas de um determinado material, dispostas entre o elemento a ser ensaiado e as placas da máquina de ensaio, que reduzem os efeitos das irregularidades no topo e base do corpo-de-prova, propiciando dessa maneira uma distribuição mais uniforme das tensões. Os diferentes materiais usados como capeamento levam a consideráveis variações nas resistências dos blocos, influenciadas pelas propriedades de deformação do material que induzem a unidade a um determinado estado de tensões.

Devido às restrições ocasionadas pela placa da máquina de ensaio, um estado triaxial é criado nas unidades, e quando colocada uma camada de material entre a unidade e essa placa o estado de tensões passa a ser influenciado pelas propriedades de deformação. De acordo com Kleeman e Page (1990), a resistência aparente das unidades pode aumentar ou diminuir de acordo com a rigidez relativa do material de capeamento e da unidade. Exemplificam que um material muito deformável se expandirá bem mais lateralmente que a unidade, induzindo-a a tensões laterais de tração, resultando uma ruína prematura por fendilhamento. De modo oposto, a maior rigidez do material de capeamento induzirá a tensões de compressão lateral que retardarão a ruína. As tensões induzidas dependem da espessura e das propriedades de deformação do material sob tensão normal e cisalhante.

As normas de cada país recomendam a utilização de diferentes tipos de capeamento. No Brasil, a NBR 7184 (1992) indica, para a regularização das faces de trabalho do elemento a ser ensaiado, a utilização de pastas ou argamassas capazes de apresentar, no momento do ensaio, resistência à compressão em corpos-de-prova cilíndricos $(50 \times 100 \mathrm{~mm})$ superior à prevista para o bloco a ensaiar. As pastas ou argamassas podem ser à base de gesso, enxofre, cimento, pozolana ou quaisquer outros 
materiais granulares que atendam aos requisitos de uniformidade e resistência exigidos pela norma, não devendo exceder espessura média de $3 \mathrm{~mm}$. Na Austrália usa-se o compensado (madeira compensada) ou a chapa de fibra prensada, com espessura entre 4 mm e 6 mm. A ASTM C 140 (1996) especifica uma fina camada de argamassa de gesso ou enxofre como capeamento rígido. Drysdale et al. (1994) citam o uso de placas de fibra, compensado ou outro material relativamente deformável como alternativas. A norma australiana AS 3700 (1998) exige que as unidades vazadas e os prismas constituídos por estas unidades sejam ensaiados usando capeamento unicamente nas paredes longitudinais, sendo os prismas construídos também com argamassa apenas nessas faces.

Os capeamentos mais comuns (argamassa, enxofre, pasta de gesso e chapa de fibra), segundo Maurenbrecher (1978), geram resultados semelhantes, desde que as superfícies de carregamento sejam perfeitamente horizontais. Materiais tipo borracha não são adequados, pois induzem a um rompimento prematuro.

Page e Kleeman (1991) realizaram ensaios de compressão em unidades vazadas de concreto e cerâmicas (com diferentes dimensões) e em prismas. Como material de capeamento foram usados o compensado e as chapas de fibra prensadas, variando-se a sua espessura entre $4 \mathrm{~mm}$ e $6 \mathrm{~mm}$. Em ensaios realizados anteriormente por Kleeman e Page (1990), os materiais apresentaram rigidez de 22 e $68 \mathrm{MPa} / \mathrm{mm}$ e módulo secante de cisalhamento de $250 \mathrm{MPa}$ e $240 \mathrm{MPa}$, respectivamente.

A resistência com o capeamento constituído por chapa de fibra prensada, além de ter uma alta variabilidade (principalmente no caso das unidades cerâmicas), levou a menores valores de resistência que os elementos ensaiados com capeamento de compensado. Page e Kleeman (1991) concluem que os resultados são coerentes com os encontrados em seus ensaios anteriores, nos quais o módulo secante de cisalhamento da chapa de fibra prensada tende a ser menor que o do compensado.

Maurício (2003) também realizou ensaios à compressão com blocos vazados de concreto $(14 \times 19 \times 29 \mathrm{~cm})$ com dois traços distintos (A e B) e capeados com diferentes tipos de material. Os resultados estão apresentados na Tabela 2.3.

Nos blocos com capeamento de borracha, a fissuração começou a baixas cargas, tornando-se intensa no decorrer do ensaio, sendo a ruína caracterizada ora por intensa fissuração, ora pelo cisalhamento diagonal (MAURÍCIO, 2003). O capeamento com enxofre e gesso acarretam as maiores resistências nos dois tipos de blocos. 
Tabela 2.3 - Resistência dos blocos vazados de concreto com diferentes tipos de capeamento, adaptada de Maurício (2003).

\begin{tabular}{ccccccc}
\hline & \multicolumn{3}{c}{ Traço A } & \multicolumn{3}{c}{ Traço B } \\
$\begin{array}{cccccc}\text { Material de } \\
\text { capeamento }\end{array}$ & $\mathrm{f}_{\mathrm{bm}}$ & $\mathrm{f}_{\mathrm{bk}}$ & $\mathrm{C} . \mathrm{V}$. & $\mathrm{f}_{\mathrm{bm}}$ & $\mathrm{f}_{\mathrm{bk}}$ & $\mathrm{C} . \mathrm{V}$. \\
& \multicolumn{2}{c}{$(\mathrm{MPa})$} & $(\%)$ & $(\mathrm{MPa})$ & $(\%)$ \\
\hline Enxofre & 10,8 & 8,9 & 11 & 4,0 & 3,3 & 11 \\
Gesso & 10,7 & 8,9 & 10 & 3,7 & 3,1 & 9 \\
Argamassa & 8,0 & 6,7 & 10 & 3,4 & 2,9 & 10 \\
Pasta de cimento & 8,2 & 6,8 & 11 & 3,3 & 2,3 & 18 \\
Forro pacote & 9,7 & 7,8 & 12 & 3,0 & 2,4 & 12 \\
Papelão & 8,6 & 7,0 & 12 & 2,7 & 1,7 & 22 \\
Borracha & 5,9 & 5,0 & 9 & 2,0 & 1,5 & 18 \\
\hline $\mathrm{f}_{\mathrm{bm}}$ : resistência média à compressão do bloco \\
$\mathrm{f}_{\mathrm{bk}}$ : resistência característica à compressão do bloco \\
C.V.: coeficiente de variação
\end{tabular}

Levando-se em conta as análises feitas por Page e Kleeman (1991), em que os materiais que apresentavam maior rigidez ao cisalhamento permitiriam aos blocos maiores cargas de compressão, e com os dados disponíveis e conhecimentos dos materiais utilizados por Maurício (2003), nota-se que os resultados obtidos com os ensaios do bloco tipo B são mais coerentes se comparados com os resultados obtidos com os blocos tipo A. Os valores mais altos encontrados para os blocos capeados com enxofre e gesso são justificados pela maior rigidez que esses possuem frente aos demais e talvez pelo maior atrito proporcionado às placas da prensa. Os baixos resultados obtidos nos ensaios com argamassa do bloco tipo A pode ter sido ocasionado pelo esmagamento precoce do material de capeamento, fato relatado por Maurício (2003).

Por ser o material mais deformável, já se esperavam as menores resistências para os blocos capeados com a borracha. As teorias citadas por Maurenbrecher (1978) e Kleeman e Page (1990) explicam tal fenômeno.

Por fim, Drysdale et al. (1994) afirmam que nenhuma das relações entre os ensaios com diversos tipos de capeamento encontradas pode ser válida em virtude das diferentes propriedades dos materiais de capeamento e dos diferentes efeitos que dependem tanto da espessura do capeamento como da tensão de ruína. Citam ainda que capeamentos deformáveis, que são totalmente prensados a cargas bem inferiores às cargas de ruína, podem causar um efeito semelhante ao da condição imposta pelo capeamento mais rígido naquele estágio. 


\subsubsection{Influência das placas de ensaio}

O objetivo da utilização das placas nos ensaios é de prover uma distribuição uniforme de tensão e deformação no elemento.

Conforme relatam Kleeman e Page (1990), devido à restrição ocasionada pelas placas, um estado de tensão complexo é criado nas regiões extremas das unidades. Assim, um aumento da resistência é induzido por um estado triaxial de tensões, a menos que a unidade tenha comprimento suficiente para que esses efeitos se tornem insignificantes. Citam ainda que, se apenas algumas partes da unidade são carregadas como nas unidades com carregamento apenas nas paredes longitudinais - a distribuição de tensões é sempre não uniforme. Porém, Atkinson (1991) ressalta que o grau de uniformidade obtido é influenciado também pela flexão e cisalhamento da placa, sendo necessário uma espessura mínima a fim de se evitar deformações excessivas. Mostra ainda uma série de prescrições de normas (americanas, canadenses e européias), em que se recomenda o diâmetro mínimo de carregamento da extremidade da prensa variando de $12,7 \mathrm{~cm}$ a $15,2 \mathrm{~cm}$ e a espessura mínima das placas, para unidades de 20 x $40 \mathrm{~cm}$ e diâmetro de carregamento de $16,5 \mathrm{~cm}$, variando entre $4,8 \mathrm{~cm}$ e $14,5 \mathrm{~cm}$. Alguns desses valores são específicos para unidades ou prismas. Também é apresentado o fator $\mathrm{K}$, que varia entre 0,33 e 1 nas normas consultadas. Esse fator parece ser de adequada utilização, pois avalia simultaneamente o diâmetro da extremidade de carregamento da prensa e as dimensões (em planta) das placas. A Equação (2.4) define o fator K e a Figura 2.2 ilustra as variáveis consideradas.

$$
\mathrm{t}=\mathrm{K}(\mathrm{D}-\mathrm{R})
$$

t é a espessura da placa de ensaio;

D é a distância entre o centro da circunferência da extremidade da célula de aplicação de carga e a quina da placa;

$\mathrm{R}$ é o raio da extremidade da célula de aplicação de carga. 

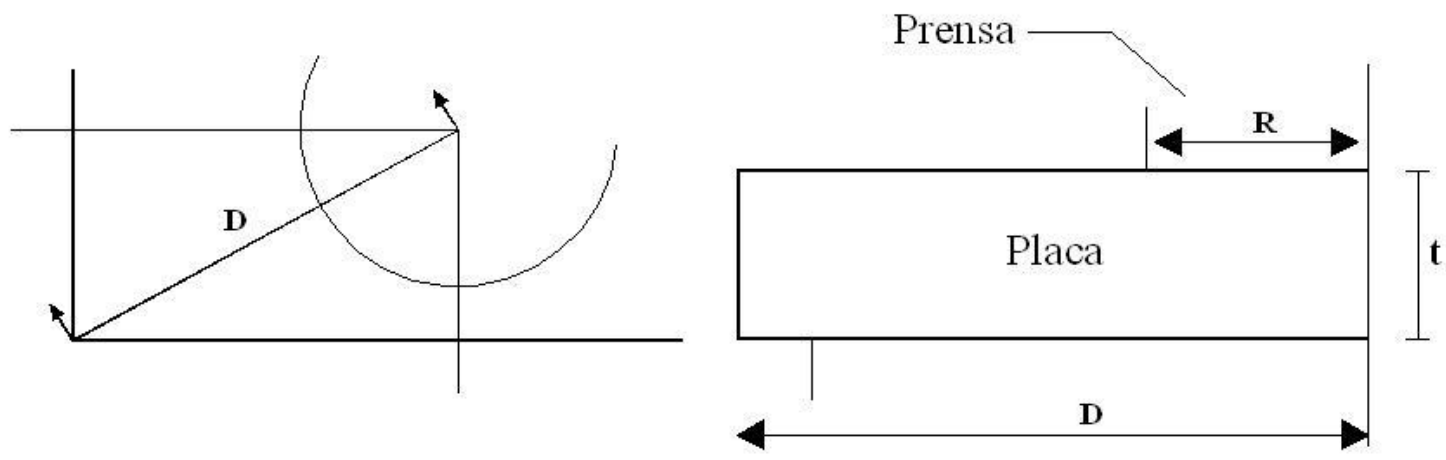

Figura 2.2 - Variáveis para definição do fator de cálculo $\mathrm{K}$ da espessura das placas de ensaio, adaptada de Atkinson (1991).

Render $(1986)^{2}$ apud Medeiros (1993) define em 75 mm a espessura mínima das placas de carregamento, evitando assim que possíveis deformações dissipem parte do carregamento. Já a NBR 7184 (1992) recomenda que as superfícies das placas devem ser planas e rígidas, não apresentando desníveis superiores a $8 \times 10^{-2} \mathrm{~mm}$ para cada $4 \mathrm{x}$ $10^{2} \mathrm{~mm}$, recomendando a espessura de no mínimo um terço da distância entre a borda do prato de apoio e o canto mais afastado do corpo-de-prova, não sendo inferior a 25 $\mathrm{mm}$.

Nos ensaios realizados por Self (1975), com o aumento da espessura da placa de $2,5 \mathrm{~cm}$ para $8,3 \mathrm{~cm}$, foi identificado um decréscimo nas deformações das paredes longitudinais, entre o centro e os extremos, de 50\%. Aumentando-se o diâmetro da extremidade da prensa de $21,6 \mathrm{~cm}$ para $25,4 \mathrm{~cm}$ houve um aumento de resistência entre $7 \%$ e $13 \%$.

Hamid e Chukwunenye (1986), por meio de simulações utilizando o Método dos Elementos Finitos, identificaram diferenças nas tensões de tração lateral quando utilizadas placas com de $5 \mathrm{~cm}, 10 \mathrm{~cm}$ e $20 \mathrm{~cm}$. As diferenças consideráveis foram apontadas quando feitas comparações entre as placas de $5 \mathrm{~cm}$ e $10 \mathrm{~cm}$ e de $5 \mathrm{~cm}$ e 20 $\mathrm{cm}$. Não foram notadas diferenças significativas entre os resultados das placas de $10 \mathrm{~cm}$ e $20 \mathrm{~cm}$. O diâmetro da extremidade da prensa era de $14 \mathrm{~cm}$ e os prismas constituídos por três blocos vazados, com juntas totalmente preenchidas. Por fim, concluem que a maior flexibilidade da placa de $5 \mathrm{~cm}$ de espessura foi a responsável por tais diferenças.

A influência da restrição das placas na resistência à compressão de unidades sólidas, de acordo com Page e Kleeman (1991), é bem conhecida e correções da resistência "aparente" podem ser feitas por meio da aplicação de fatores que geralmente são expressos em função da relação altura/largura do elemento ensaiado. A norma 
australiana AS 3700 (1998) adota essa correção para as unidades sólidas. No caso de unidades vazadas, a distribuição de tensões se torna muito mais complexa.

Uma investigação sobre tal fenômeno foi feita por Page e Kleeman (1991) com a realização de uma série de ensaios com unidades e prismas. Dois métodos de ensaio foram utilizados, dentre eles o método de ensaio padrão. O outro método utiliza uma placa modificada, constituída por uma série de filamentos de aço delgados (brush platens), que transmitia a carga em sua extremidade. Essas placas modificadas minimizam o efeito da restrição lateral, pois cada filamento é capaz de transmitir individualmente a sua parte da força vertical, fletindo-se lateralmente com a expansão da espécie devido à sua baixa rigidez ao cisalhamento. A Figura 2.3 ilustra a placaescova (a) e o modo de ruína de um tijolo (b).

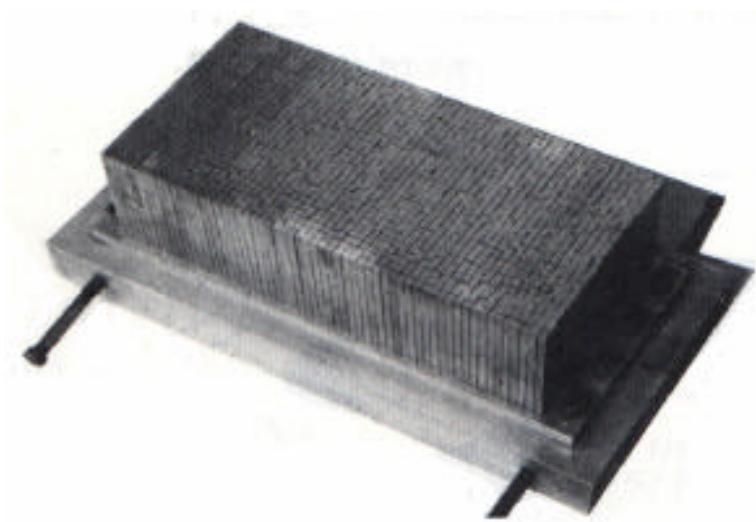

(a)

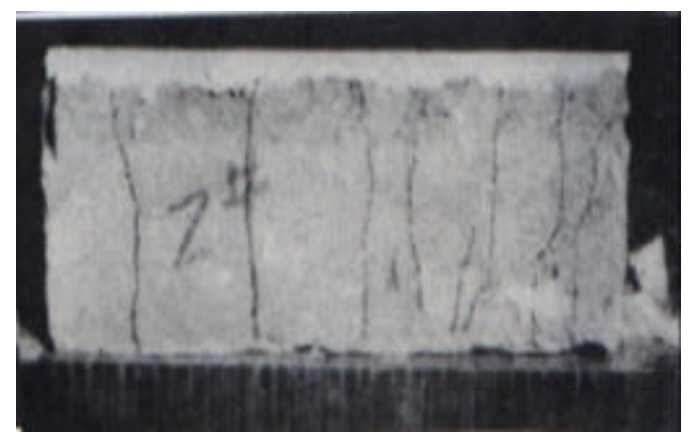

(b)

Figura 2.3 - Ensaio de compressão axial em unidades de alvenaria utilizando placa-escova. Placa-escova (a) e ruína do bloco (b), Drysdale et al. (1994).

Os ensaios foram realizados com unidades de 200 x 200 x $400 \mathrm{~mm}$, instrumentando-se os 3 septos transversais para medição da fissuração.

A fissuração das unidades no ensaio padronizado iniciou-se na base dos septos transversais externos a $33 \%$ da força última. Esse fenômeno foi seguido por uma progressiva fissuração dos três septos transversais e finalmente pela separação das paredes longitudinais na região entre o septo transversal central e o septo transversal externo. Nos ensaios utilizando a placa-escova, a primeira fissuração ocorreu na base do septo transversal central a $35 \%$ da força última. Com o aumento da força houve aumento da fissuração e novas fissuras surgiram nos demais septos transversais. Na força última, as fissuras dos septos transversais progrediram até o topo da unidade e em ambos os casos houve separação na base das paredes longitudinais (PAGE e KLEEMAN, 1991). A Tabela 2.4 agrupa os resultados obtidos nos ensaios. 
Tabela 2.4 - Resultados dos ensaios com unidades e prismas, adaptada de Page e Kleeman (1991).

\begin{tabular}{cccc}
\hline Tipo do ensaio & $\begin{array}{c}\text { Carga média } \\
\text { de fissuração } \\
(\mathrm{kN})\end{array}$ & $\begin{array}{c}\text { Carga média } \\
\text { última } \\
(\mathrm{kN})\end{array}$ & Relação $\mathrm{C}_{\mathrm{f}} / \mathrm{C}_{\mathrm{u}}{ }^{1}$ \\
\hline Bloco (padrão) & 165 & 490 & 0,33 \\
Bloco (placa-escova) & 120 & 348 & 0,35 \\
Prisma (padrão) & 105 & 409 & 0,26 \\
\hline${ }^{1} \mathrm{C}_{\mathrm{f}}$ : carga de fissuração & & & \\
$\mathrm{C}_{\mathrm{u}}$ : carga última & &
\end{tabular}

Os resultados mostram que houve restrição significativa das placas no ensaio padrão, indicado pelos valores mais baixos da carga de fissuração e da carga última em relação aos ensaios com a placa-escova. Essa diferença é evidente embora o modo de ruína seja semelhante, afirmam Page e Kleeman (1991).

Observa-se uma redução em torno de $28 \%$, tanto na carga de fissuração quanto na carga última, se comparados os resultados do ensaio padrão com os resultados do ensaio com placas-escova.

Page e Kleeman (1991) comparam o comportamento dos blocos durante os ensaios, descrevendo que "[...] a fissuração no ensaio padrão não propagou livremente devido à restrição da expansão lateral. A ruína ocorreu no momento em que foram desenvolvidas tensões suficientes para iniciar a fissuração nas paredes longitudinais. Houve ainda uma variabilidade maior na localização da primeira fissura no septo transversal. Nos ensaios com placa-escova a fissuração ocorreu em toda altura da unidade e em todos os septos transversais, surgindo apenas uma pequena fissuração nas paredes laterais."

Também foram realizados ensaios a fim de comparar o comportamento dos blocos isolados com o comportamento dos blocos quando formam um prisma de três elementos. Para monitorar a fissuração dos septos transversais, o bloco central foi instrumentado de forma semelhante aos blocos quando ensaiados isoladamente. Foi observado que os blocos de topo e base sofreram pouca fissuração devido à restrição da prensa. Na Tabela 2.4 também apresentam-se os resultados obtidos nos ensaios com prismas.

Algumas comparações podem ser feitas com os resultados obtidos. Utilizandose o conceito de fator de eficiência (relação entre a resistência do prisma e a do bloco $\mathrm{f}_{\mathrm{p}} / \mathrm{f}_{\mathrm{b}}$ ), aplicado aos valores da resistência do bloco obtida por meio do ensaio com placa- 
escova, e do prisma obtida por meio do ensaio convencional, encontra-se $f_{p} / f_{b}=1,18$, ou seja, a resistência do prisma é aproximadamente $18 \%$ maior que a resistência dos blocos, não condizendo com os resultados encontrados em diversas bibliografias. Cavalheiro e Gomes (2002) resumem valores encontrados para blocos de concreto em que o fator de eficiência entre o prisma e o bloco varia de 0,69 a 0,86 , uma redução

entre $14 \%$ e $31 \%$ na resistência dos prismas. Nos ensaios com prismas de Page e Kleeman (1991) o bloco central está mais distante dos efeitos de restrição das placas e devido à sua maior relação h/t, em relação aos blocos, acredita-se que exista uma redução mais significativa do efeito de confinamento exercido pelas placas sobre os prismas. A utilização de placa-escova nesse ensaio acarretaria menores diferenças que as obtidas nos ensaios com blocos.

Nestes ensaios observa-se um aumento de resistência em torno de 40\%, comparando-se o ensaio com placas-escova com o ensaio padrão. A resistência obtida por meio de ensaios padronizados - resistência "aparente" - para esse bloco particular, seria em torno de $40 \%$ superior à resistência "real" do bloco.

É recomendado por Drysdale et al. (1994) que nos ensaios científicos sejam utilizados modelos mais exatos, utilizando-se capeamentos mais deformáveis, lâminas de teflon (resina sintética) e placas engraxadas.

\subsection{Ensaios com material que constitui o bloco}

Marzahn (2003) recorda que a capacidade da alvenaria é determinada a partir das propriedades dos seus componentes, por meio de ensaios padronizados, obtendo suas características básicas e permitindo a previsão da carga de ruína. Entretanto, complementa o autor, para uma investigação mais profunda do comportamento estrutural, aquelas propriedades não são adequadas para representar determinadas condições como, por exemplo, uma Micromodelagem Numérica dos elementos para simulação computacional da alvenaria ou das condições de ruína.

Algumas pesquisas tratam da correlação entre as resistências do material concreto - que constitui o bloco - e a resistência do bloco, visando conhecer as propriedades mecânicas desse material. Todavia, apenas poucas delas abordam tal assunto como objetivo principal, e as que o fazem, analisam em sua maioria a resistência de blocos não padronizados, procurando estabelecer correlações diretas com as resistências obtidas de corpos-de-prova extraídos das paredes dos blocos. 
Becica e Harris (1983) realizaram análises experimentais com blocos de concreto, prismas e corpos-de-prova extraídos do bloco. Apesar das análises do bloco e do material não serem o enfoque principal dos experimentos, nota-se o empenho em conhecer as propriedades do concreto que constitui o bloco já que, além da simples correlação entre as resistências do material e do bloco, foi obtida a curva tensãodeformação dos corpos-de-prova, bem como estudada a maneira de instrumentá-los.

Ensaiaram-se blocos vazados de concreto com dimensões nominais de $200 \mathrm{x}$ 200 x 390 mm, com relação entre a área líquida e área bruta igual a 0,54. Os corpos-deprova foram extraídos da unidade e ensaiados obtendo-se a resistência do concreto (material constituinte do bloco) e suas propriedades mecânicas. Ensaiaram-se 10 CPs com relação altura/comprimento variando entre 1:1 e 2:1, permanecendo a espessura (e sua geometria) com a mesma inclinação encontrada nos blocos. A resistência à compressão média foi de $18,4 \mathrm{MPa}$. A Figura 2.4 apresenta as curvas tensãodeformação obtidas a partir do ensaio de três corpos-de-prova, com instrumentação colocada na face interna e externa. Os autores evidenciam a mudança de comportamento das curvas quando as deformações são medidas na parte externa ou interna (que possui inclinação em torno de $2 \%$ ). As curvas apresentam um trecho linear seguido de um trecho com não-linearidade até se atingir a tensão máxima. Os trechos lineares mais extensos são os das curvas nas quais a medição foi realizada na parte externa.

Realizaram-se também ensaios com blocos e prismas constituídos de três blocos. As resistências médias e as deformações últimas para cada um desses elementos ensaiados estão agrupadas na Tabela 2.5.

A Figura 2.5 apresenta uma comparação entre as curvas tensão-deformação dos elementos ensaiados.

A deformação última dos corpos-de-prova de concreto é bem maior que a dos outros dois elementos, o que indica uma perda de ductilidade, em virtude do maior confinamento a que os blocos e os prismas estão submetidos (BECICA e HARRIS, 1983).

A ruína dos corpos-de-prova de concreto extraídos do bloco foi do tipo cisalhamento diagonal em suas faces. Ocorreu também o fendilhamento em algumas amostras. Becica e Harris (1983) relatam que a ruína se mostrou dúctil e em alguns casos um encurtamento significativo foi verificado. 

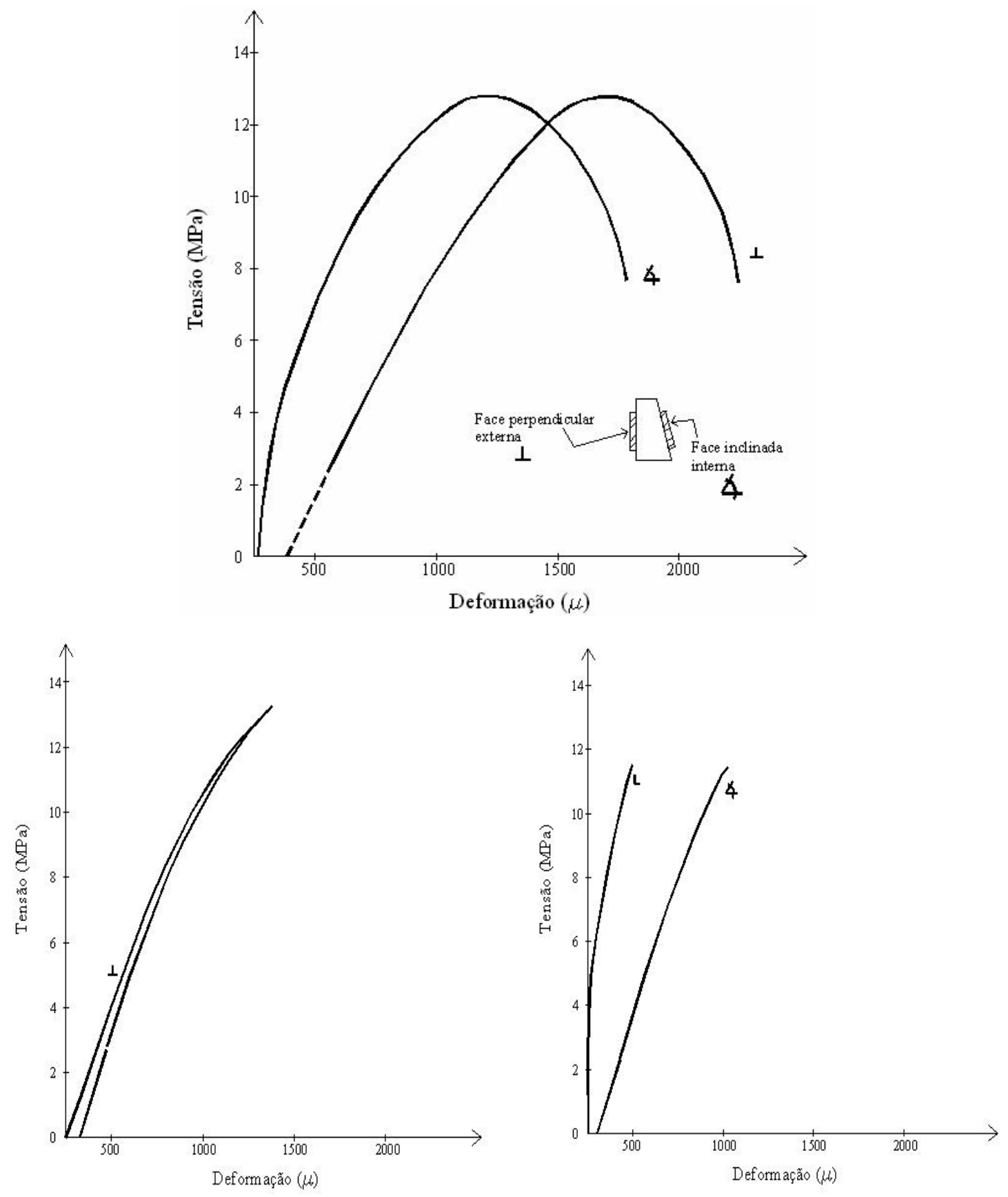

Figura 2.4 - Curvas tensão-deformação obtidas no ensaio de corpos-de-prova extraídos dos blocos de concreto com indicação do posicionamento dos extensômetros (na face externa ou interna), Becica e Harris (1983).

Tabela 2.5 - Resistência e deformação dos blocos, prismas e corpos-de-prova de concreto.

\begin{tabular}{cccc}
\hline \multirow{2}{*}{ Elemento ensaiado } & \multicolumn{2}{c}{ Resistência $(\mathrm{MPa})$} & \multirow{2}{*}{ Deformação $(\mu)$} \\
& Área bruta & Área líquida & \\
\hline Corpo-de-prova & - & 18,4 & 2094 \\
Bloco & 9,8 & 15,1 & 1805 \\
Prisma & 5,2 & 8,0 & 1652 \\
\hline
\end{tabular}




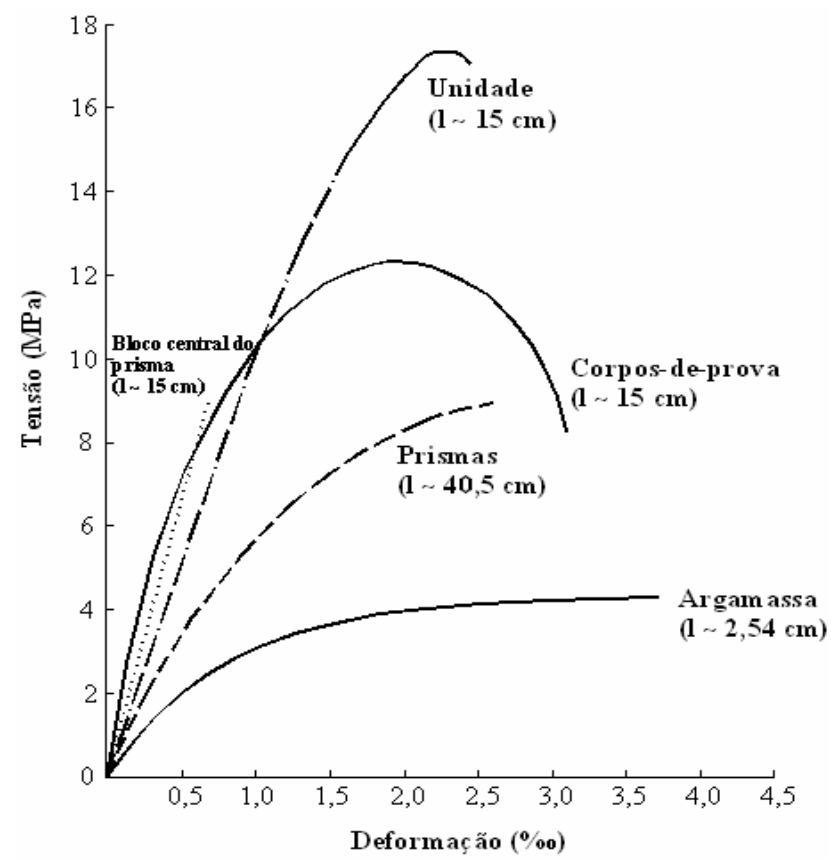

Figura 2.5 - Curvas tensão-deformação dos materiais e comprimento da base de medida utilizada nos ensaios, adaptada de Becica e Harris (1983).

Ganzerli et al. (2003) também realizam ensaios com corpos-de-prova extraídos das unidades. Esse tipo de ensaio é uma das modificações que a ASTM C 140 (1996) permite para ensaios de unidades não padronizadas que são largamente empregadas nos Estados Unidos. As unidades não padronizadas possuem, por exemplo, uma maior projeção das paredes longitudinais, maiores alturas e interrupções nos septos transversais.

O trabalho também apresenta um histórico das pesquisas que realizaram ensaios à compressão com corpos-de-prova extraídos dos blocos de concreto realizados nos últimos anos no estado da Califórnia. Os ensaios buscavam avaliar quais proporções dos corpos-de-prova que forneciam melhores resultados comparados com os resultados obtidos em ensaios com blocos, quando ensaiados à compressão. Dentre eles estão os ensaios realizados:

a) por Timothy Mallis, em 1986, que relata que as melhores concordâncias entre resistência à compressão de CPs (1:4, relação espessura:comprimento) e blocos são obtidas quando extraídas amostras com dimensões na proporção de 1:3:4 (espessura:altura:comprimento), enfatizando que se deve atentar para o tipo de capeamento usado a fim de se obter resultados equivalentes;

b) em 1987, na Riverside Cement Association, com CPs de diversas proporções, em que as amostras que possuem dimensões nas proporções de 1:3:5 
(espessura:altura:comprimento) mostrou-se mais correlata com as unidades de dimensões nominais de $20 \times 20 \times 40 \mathrm{~cm}$.

Segundo Ganzerli et al. (2003), as proporções de 1:5 apresentaram os resultados mais próximos aos encontrados nos ensaios com blocos, comprovando também que a variação das dimensões é capaz de alterar de forma significativa os resultados dos ensaios. Citam ainda que nas prescrições da ASTM C 140 (1996), ensaiando-se CPs nas proporções de 1:2:4 (espessura:altura:comprimento), encontraram-se resistências de CPs 16\% menores e 32\% maiores que a resistência dos blocos, sendo notado que a localização de extração do CP (topo, base ou seção média) influencia significativamente nos resultados.

Análise semelhante foi realizada por Hawk et al. (1997). Ensaiou-se uma unidade de largura nominal de $25 \mathrm{~cm}$, na qual as paredes longitudinais se estendiam além dos encontros com os septos transversais, que não possuíam altura constante. Para a realização dos ensaios utilizaram-se três modelos de blocos: sem modificações (i), com altura do bloco nivelada com a menor altura dos septos transversais (ii) e com o bloco com altura nivelada e com a projeção das paredes longitudinais cortadas (iii). Foram extraídos corpos-de-prova da unidade, obtendo-se resistência à compressão média de 21,9 MPa, enquanto que a resistência dos modelos i, ii e iii foram respectivamente 23,8 $\mathrm{MPa}, 23,5 \mathrm{MPa}$ e 25,4 $\mathrm{MPa}$, calculadas em relação à área líquida. Nesse caso particular, a resistência do CP foi menor que a resistência de qualquer um dos três modelos de blocos.

Nos ensaios realizados por Ganzerli et al. (2003) utilizaram-se blocos de concreto de dimensões de 20 × 20 x $40 \mathrm{~cm}$. Além da forma padronizada, foram usados outros quatro tipos (todos com suas dimensões adaptadas, removidas as projeções das paredes). Para cada forma, foram ensaiados três blocos à compressão e outros três foram utilizados pra extração de corpos-de-prova, do topo e da base das paredes longitudinais. A relação entre espessura, altura e comprimento foi de 1:2:4 (aproximadamente 3,5 x 7 x 14 cm). Os valores obtidos para o bloco padrão estão na Tabela 2.6.

A resistência à compressão, tanto para os blocos padronizados quanto para as outras formas de bloco, na maioria das vezes foram menores que as dos respectivos corpos-de-prova. Ganzerli et al. (2003) justificam tal fato devido à diferença de forma entre os dois modelos, pois enquanto os CPs são sólidos e com dimensões bem menores que os blocos, estes possuem vazios (modificando a sua superfície de carregamento) 
com paredes longitudinais esbeltas. Além disso, por possuírem menores dimensões, os CPs têm uma menor probabilidade de possuírem falhas no seu interior.

Tabela 2.6 - Resultados dos ensaios à compressão com blocos e corpos-de-prova extraídos, adaptada de Ganzerli et al. (2003).

\begin{tabular}{cccc}
\hline Elemento & $\begin{array}{c}\text { Resistência à } \\
\text { compressão média na } \\
\text { área líquida (MPa) }\end{array}$ & $\begin{array}{c}\text { Desvio padrão } \\
(\mathrm{MPa})\end{array}$ & $\begin{array}{c}\text { Coeficiente } \\
\text { de variação } \\
(\%)\end{array}$ \\
\hline Bloco 20 x 20 x 40 & 34,8 & 1,31 & 3,8 \\
Corpo-de-prova (Topo) & 49,1 & 0,14 & 0,3 \\
Corpo-de-prova (Base) & 39,0 & 3,65 & 9,4 \\
\hline
\end{tabular}

Tomando-se a média entre as resistências dos corpos-de-prova, observa-se que essa é em torno de $26 \%$ maior que a resistência dos blocos, considerando-se a área líquida. A diferença entre as resistências do topo e da base provavelmente é ocasionada em virtude da variação do grau de compactação nas camadas dos blocos.

Marzahn (2003) realizou análise experimental com blocos silico-calcários (A e B) e de concreto autoclavados (C e D) com ar incorporado, extraindo de ambos corposde-prova cilíndricos. Esses ensaios objetivavam investigar mais detalhadamente as propriedades mecânicas das unidades de alvenaria. Realizaram-se com os blocos ensaios à compressão axial $\left(\mathrm{f}_{\mathrm{b}}\right)$ e de resistência à tração (indireta, $\mathrm{f}_{\mathrm{bt}, \mathrm{sp}}$, e na flexão, $\mathrm{f}_{\mathrm{bt}, \mathrm{f}}$ ). Além do ensaio padronizado à compressão, ensaiaram-se os blocos com o plano de carregamento paralelo ao seu comprimento, ensaio denominado pelo autor de compressão longitudinal $\left(f_{b, 1}\right)$. Os blocos utilizados eram sólidos, com dimensões e massas específicas apresentadas na Tabela 2.7, juntamente com os resultados dos ensaios à compressão. Os valores obtidos no ensaio padrão foram corrigidos, levando em consideração o fator de forma dos blocos; o que ocorreu também no cálculo da resistência à tração na flexão, para levar em conta a distorção devido ao cisalhamento nas seções transversais do bloco. No ensaio à tração indireta, a força foi aplicada longitudinalmente, paralela ao comprimento do bloco. Os resultados dos ensaios à tração são apresentados na Tabela 2.8.

Extraíram-se corpos-de-prova 10 x $20 \mathrm{~cm}$ dos blocos, os quais foram submetidos à compressão axial, medindo-se os seus deslocamentos longitudinal e transversal. Observoutse por meio das curvas tensão-deformação que o aumento da resistência conduz a um aumento da inclinação inicial da curva, além de uma ruína menos dúctil com as deformações atingindo maiores valores. Marzahn (2003) sugere que o módulo de deformação longitudinal do corpo-de-prova $\left(\mathrm{E}_{\mathrm{b}}\right)$, definido pela 
inclinação da reta que une a origem do eixo ao ponto de tensão equivalente a $33 \%$ da tensão máxima, seja calculado por meio da Equação (2.5):

$$
\mathrm{E}_{\mathrm{b}}=450 \mathrm{f}_{\mathrm{b}, \mathrm{cil}}
$$

$\mathrm{f}_{\mathrm{b}, \mathrm{cil}}$ é a resistência à compressão axial obtida em CPs cilíndricos.

Tabela 2.7 - Resistência à compressão dos blocos e corpos-de-prova, adaptada de Marzahn (2003).

\begin{tabular}{|c|c|c|c|c|c|c|c|}
\hline Bloco & $\begin{array}{l}\text { Dimensões } \\
(\mathrm{mm})\end{array}$ & $\begin{array}{c}\text { Massa } \\
\text { específica } \\
\left(\mathrm{kgf} / \mathrm{cm}^{3}\right)\end{array}$ & \multicolumn{4}{|c|}{ (MPa) } & $\frac{\mathrm{f}_{\mathrm{b} . \mathrm{cil}}}{\mathrm{f}_{\mathrm{b}}}$ \\
\hline A & $238 \times 24$ & 1857 & 25,9 & - & 17,1 & 10088 & 0,66 \\
\hline B & $250 \times 240 \times 300$ & 1864 & 20,9 & 10,3 & 12,8 & 9908 & 0,61 \\
\hline $\mathrm{C}$ & 00 × 240 y 500 & 544 & 4,1 & 3,2 & 3,9 & 1938 & 0,95 \\
\hline D & $200 \times 240 \times 500$ & 450 & 3,2 & 1,8 & 2,8 & 1516 & 0,86 \\
\hline
\end{tabular}

Tabela 2.8 - Resistência à tração dos blocos e corpos-deprova, adaptada de Marzahn (2003).

\begin{tabular}{ccccc}
\hline Bloco & $\mathrm{f}_{\mathrm{bt}, \mathrm{fl}}$ & $\begin{array}{c}\mathrm{f}_{\mathrm{bt}, \mathrm{sp}} \\
(\mathrm{MPa})\end{array}$ & $\mathrm{f}_{\mathrm{bt}, \mathrm{ax}}$ & $\mathrm{f}_{\mathrm{bt}, \mathrm{sp}} / \mathrm{f}_{\mathrm{b}}$ \\
\hline $\mathrm{A}$ & 2,21 & 1,19 & 1,42 & 0,04 \\
B & 1,99 & 0,95 & 1,56 & 0,04 \\
$\mathrm{C}$ & 0,93 & 0,33 & 0,95 & 0,08 \\
D & 0,57 & 0,27 & 0,46 & 0,08 \\
\hline
\end{tabular}

O coeficiente de Poisson vale 0,10 e 0,20 para os CPs extraídos do bloco silicocalcários e do bloco de concreto, respectivamente.

Também realizaram-se ensaios de tração direta $\left(f_{b t, a x}\right)$ com corpos-de-prova cilíndricos de 10 x $10 \mathrm{~cm}$, sendo sugerida a Equação (2.6) para relacionar a resistência entre dois corpos-de-prova similares quando ensaiados à tração direta e à compressão axial:

$$
\mathrm{f}_{\mathrm{bt}, \mathrm{ax}}=0,26 \mathrm{f}_{\mathrm{b}, \mathrm{cil}}
$$

$\mathrm{f}_{\mathrm{btax}}$ é a resistência à tração direta.

Pode-se observar que os CPs apresentaram resistência que valem de $60 \%$ a $65 \%$ da resistência do bloco silico-calcário e de $85 \%$ a $90 \%$ da resistência dos blocos de 
concreto. Nos ensaios à compressão longitudinal, com a diminuição do valor da resistência essa relação tende a aumentar, passando os CPs a possuírem maiores valores de resistência que o bloco. A resistência à tração indireta vale aproximadamente $4 \%$ da resistência à compressão dos blocos silico-calcários e $8 \%$ da resistência dos blocos de concreto. Marzahn (2003) justifica que a escolha dessa geometria de corpos-de-prova se deu em virtude destes serem amplamente aceitos no estudo das propriedades mecânicas do concreto, oferecendo a vantagem de uma variedade de relações altura/diâmetro.

A resistência à compressão e à tração do concreto, medida em corpos-de-prova, de acordo com Neville (1997), estão estreitamente relacionadas, entretanto, não existe uma proporcionalidade direta, pois essa relação depende do nível de resistência do concreto. Quando se aumenta a resistência à compressão, a resistência à tração também aumenta, mas em uma razão decrescente. Cita ainda que, depois de cerca de um mês a resistência à tração aumenta mais lentamente do que a resistência à compressão.

Como a resistência à tração pode ser determinada por ensaios distintos (tração na flexão, tração direta e tração indireta), a relação com a resistência à compressão também possui diferentes valores.

A resistência do concreto à tração indireta (por compressão diametral) $\mathrm{fttsp}_{\text {sp }}$ é determinada segundo as prescrições NBR 7222 (1994). A resistência do concreto à tração direta $\mathrm{f}_{t}$, de acordo com a NBR 6118 (2003), pode ser considerada igual a 0,9 $\mathrm{f}_{\mathrm{ct}, \mathrm{sp}}$. A norma permite também, na falta de ensaios, avaliar o seu valor médio ou característico por meio das Equações (2.7), (2.8) e (2.9).

$$
\begin{gathered}
\mathrm{f}_{\mathrm{ct}, \mathrm{m}}=0,3 \mathrm{f}_{\mathrm{ck}}^{2 / 3} \\
\mathrm{f}_{\mathrm{ctk}, \mathrm{nnf}}=0,7 \mathrm{f}_{\mathrm{ct}, \mathrm{m}} \\
\mathrm{f}_{\mathrm{ctk}, \text { sup }}=1,3 \mathrm{f}_{\mathrm{ct}, \mathrm{m}}
\end{gathered}
$$

Marzahn (2003) ainda sugere as Equações (2.10) e (2.11) para correlacionar as resistências à tração obtidas pelos diferentes métodos de ensaio:

$$
\mathrm{f}_{\mathrm{bt}, \mathrm{ax}}=0,72 \mathrm{f}_{\mathrm{btsp}}
$$

$\mathrm{f}_{\mathrm{btspp}}$ é a resistência à tração indireta. 


$$
\mathrm{f}_{\mathrm{bt}, \mathrm{ax}}=0,50 \mathrm{f}_{\mathrm{b}, \mathrm{fl}}
$$

$\mathrm{f}_{\mathrm{b}, \mathbb{f l}}$ é a resistência à tração na flexão.

Uma nova metodologia de correlação entre resistência do corpo-de-prova e dos blocos de concreto foi desenvolvida por Frasson Júnior (2000). Utilizaram-se fôrmas cilíndricas para a moldagem dos corpos-de-prova de $5 \times 10 \mathrm{~cm}$, e a partir dos seus ensaios e correlações com os blocos de concreto, desenvolveutse uma metodologia de dosagem e controle do processo produtivo para blocos de concreto.

Apesar de tal estudo ser apenas uma das etapas da pesquisa, é interessante perceber a busca do autor não só por um método menos dispendioso, mas também na visão que teve em buscar conhecimento no material de produção para se caracterizar o componente estrutural. A facilidade dos ensaios com CPs são evidentes se comparadas com os ensaios e estudos com blocos que utilizam estritamente a fábrica, pois este se torna um procedimento que encarece e dificulta a dosagem, havendo a necessidade de uma forma simples e eficaz (FRASSON JÚNIOR, 2000).

A moldagem dos CPs ocorreu durante a produção dos blocos nas fábricas, em que eram retiradas amostras do concreto seco da mesma porção que se moldavam os blocos. Os elementos eram colocados juntos na cura (à vapor), garantindo dessa forma a semelhança entre eles.

A análise experimental consistiu na moldagem de três séries de blocos de dimensões 14 x 19 x 39 cm, duas geometrias (com paredes "grossas" e "finas") e três distintas resistências (6 MPa, $9 \mathrm{MPa}$ e $12 \mathrm{MPa}$ ). Para cada uma das séries de blocos foram produzidos $4 \mathrm{CPs}$.

A Tabela 2.9 apresenta os valores das resistências dos CPs e dos blocos, sendo as comparações realizadas em relação à área líquida dos blocos.

Tabela 2.9 - Correlação entre as resistências dos CPs e dos blocos de concreto, adaptada de Frasson Júnior (2000).

\begin{tabular}{ccccccc}
\hline \multicolumn{4}{c}{ Resistência (MPa) } \\
\hline \multirow{3}{*}{ Área bruta } & \multicolumn{3}{c}{ Parede Fina } & \multicolumn{3}{c}{ Parede Grossa } \\
& Bloco & CP & $\begin{array}{c}\text { CP/Bloco } \\
(\%)\end{array}$ & Bloco & CP & CP/Bloco \\
& & & $(\%)$ \\
\hline 6 & 18,5 & 14,5 & 78,4 & 16,4 & 13,0 & 79,3 \\
9 & 27,0 & 21,0 & 77,8 & 21,4 & 17,4 & 81,3 \\
12 & 32,4 & 26,0 & 80,2 & 32,8 & 25,3 & 77,1 \\
\hline
\end{tabular}


Com base nos resultados, Frasson Júnior (2000) conclui que, para um corpode-prova cilíndrico de $5 \times 10 \mathrm{~cm}$, de mesmo traço e mesma massa específica que um certo bloco de concreto, sua resistência é em torno de $80 \%$ da resistência do bloco, tomada na área líquida.

Acredita-se que existam fatores que são desconhecidos e que possam ser correlacionados com as unidades das estruturas de alvenaria e talvez até com as próprias estruturas.

As pesquisas que objetivam caracterizar as propriedades mecânicas do material que constitui a unidade de alvenaria encontrarão várias dificuldades, principalmente pelo fato dos blocos de concreto sofrerem um processo de moldagem diferente dos convencionalmente adotados para os concretos plásticos. Assim, os equipamentos a que se destina a moldagem e adensamento do concreto plástico não satisfazem, em tese, os procedimentos utilizados para adensamento do concreto "seco". Por esse motivo, algumas pesquisas utilizam corpos-de-prova extraídos do próprio bloco, garantindo dessa forma, a igualdade entre as características dos materiais (no bloco e no corpo-deprova). A extração dos CPs, apesar de representarem mais precisamente as características do material, é um método que requer um trabalho mais cuidadoso, demandando maiores custos e tempo, além da possibilidade da ocorrência de danos ao CP durante a extração.

Uma maior padronização quanto aos CPs mostra-se necessária, visto que a restrição ocasionada pelos pratos da prensa e a própria geometria exercerão influência significativa nos resultados obtidos. Nos resultados obtidos por Becica e Harris (1983) e Ganzerli et al. (2003) a resistência obtida em corpos-de-prova é em torno de $24 \%$ maior que a resistência dos blocos, enquanto que Frasson Júnior (2000) encontra resistências de corpo-de-prova aproximadamente $20 \%$ menores que as resistências dos blocos. Nos ensaios de Marzahn (2003) este valor de resistência variou entre 60\% a 95\% da resistência do bloco, dependendo do tipo de bloco estudado. É evidente que cada caso tem suas particularidades, sendo utilizados CPs com geometrias distintas, prismáticas e cilíndricas (que possui uma maior esbeltez e configuração que sofre menor atuação do confinamento), além de diferirem nas dimensões de base e altura e na sua frma de obtenção, se por moldagem ou extração a partir dos blocos. Entretanto, para avançar em busca de outras correlações faz-se necessário a definição de um corpo-de-prova que melhor represente o comportamento do bloco quando submetido a ensaios de compressão. Em relação ao processo de adensamento, é essencial pleno domínio da 
técnica a fim de se obter uma energia próxima a que estão submetidos os blocos na vibro-prensagem.

Prudêncio Júnior (2003) cita ainda que como a resistência do bloco, mesmo em área líquida, depende fundamentalmente da espessura de suas paredes e também da conicidade dos furos, a relação encontrada no trabalho de Frasson Júnior (2003) não é absoluta e deve ser pesquisada caso a caso.

\subsection{Ensaios com materiais substituindo a junta de argamassa}

As propriedades dos materiais dispostos horizontalmente exercem influência na resistência alcançada pela alvenaria, sejam eles a junta de argamassa ou qualquer outro material. Essa influência foi analisada por diversos autores, citados por Hendry (1998). A seguir são descritos alguns desses experimentos.

Francis et al. $(1971)^{8}$ mostraram que prismas de tijolos de alvenaria, constituídos por tijolos soltos, atingiu resistência à compressão aproximadamente duas vezes mais alta que as obtidas por prismas com juntas de argamassa normal.

Em ensaios realizados na Structural Clay Products Research Foundation, nos Estados Unidos em $1967^{9}$, foram estudados os efeitos na resistência à compressão de corpos-de-prova formados por tijolos em que os materiais da junta eram uma chapa de alumínio de $0,8 \mathrm{~mm}$ de espessura, colocadas entre as superfícies de base, uma argamassa normal de cimento, cal e areia, e uma junta de areia seca contida por uma tira de adesivo.

Nos experimentos de Morsy $(1968)^{10}$, os prismas de tijolos receberam materiais com rigidezes distintas, que variavam desde, uma borracha até o aço. Os resultados mostraram que há uma variação de até oito vezes na resistência dos prismas com a substituição do aço pela borracha nas juntas horizontais. Complementa que nos elementos com borracha, os blocos rompem por tração, como resultado das tensões de tração induzidas pela deformação do material. No caso do aço nas juntas horizontais houve um efeito de restrição lateral dos tijolos, induzindo-os a um estado de tensão

\footnotetext{
8 FRANCIS, A.J.; HORMAN, C.B.; JEREMS, L.E. (1971). The effect of joint thickness and other factors on the compressive strength of brickwork. In: International Brick Masonry Conference, 2., 1971. Proceedings. p.31-37.

9 MONK, C.B. (1967). A historical survey and analysis of the compressive strength of brick masonry. Research Report n.12. Structural Clay Products Research Foundation, Geneva.

${ }^{10}$ MORSY, E. H. (1967). An investigation of mortar properties influencing brickwork strength. $\mathrm{PhD}$ Thesis - University of Edinburgh.
} 
triaxial. Esse estado se aproxima do provocado pela restrição das placas nos ensaios com unidades isoladas. Relata que a ruína nesse caso foi dada pelo esmagamento como no ensaio típico à compressão de materiais frágeis. Agrupam-se na Tabela 2.10 os resultados desses ensaios.

Tabela 2.10 - Resistência à compressão de "prismas" de tijolos com diferentes materiais na junta, adaptada de Monk (1967) ${ }^{9}$ e Morsy $(1967)^{10}$ apud Hendry (1998).

\begin{tabular}{ccc}
\hline Material da junta & $\begin{array}{c}\text { Resistência à compressão } \\
\left(\mathrm{N} / \mathrm{mm}^{2}\right)\end{array}$ & $\begin{array}{c}\text { Relação com a resistência } \\
\text { do bloco }\end{array}$ \\
\hline Aço & 56,5 & 1,4 \\
Madeira compensada & 46,4 & 1,15 \\
Papelão rígido & 43,9 & 1,09 \\
Placa de alumínio & 106 & 0,96 \\
Sem material na junta & 37,2 & 0,93 \\
"Contato direto" & 98 & 0,89 \\
Areia & 65 & 0,59 \\
Polietileno & 17 & 0,42 \\
Argamassa (1:0,5: 4,5) & 44 & 0,40 \\
Argamassa (1:0,25:3) & 14 & 0,35 \\
Borracha com fibras & 11,7 & 0,29 \\
Borracha macia & 7 & 0,17 \\
\hline
\end{tabular}

Drysdale e Hamid (1979) realizaram ensaios com prismas constituídos por três blocos sem junta de argamassa, de formato aproximadamente quadrado (14,5 x 14,5 $\mathrm{cm}$ ), área bruta de $210 \mathrm{~cm}^{2}$ e área líquida de $122,9 \mathrm{~cm}^{2}$, com resistência média de 32,2 MPa. Uma camada de pasta de cimento foi colocada entre os blocos. Os prismas atingiram uma resistência de 28,8 MPa. Esta resistênc ia é mais alta quando comparada com os resultados em que se utilizam juntas de argamassa, pois não há a presença de um material menos resistente - e mais deformável - entre os blocos e os valores de resistência são mais próximos aos encontrados em um ensaio com bloco isolado. Nesses ensaios, os blocos ainda têm "sua resistência elevada" em virtude do maior efeito de confinamento ao qual ele está submetido, devido às suas menores dimensões. Apenas para comparação, os prismas ensaiados com junta de argamassa com resistência média de 14,2 MPa e espessura de 9,5 mm, apresentaram resistência de 27,6 MPa.

$\mathrm{Na}$ caracterização dos materiais a serem utilizados na experimentação de painéis acoplados, Corrêa (2003) realizou ensaios com prismas para determinar o módulo de deformação longitudinal do material do tijolo e da argamassa. Realizaram-se ensaios com duas séries de prismas, constituídos por cinco tijolos (cerâmicos com 
dimensões de $110 \times 76$ × $228 \mathrm{~mm}$, prensados a seco) sendo a primeira com todas as juntas de argamassa e a segunda com duas juntas intermediárias substituídas por camadas muito finas de cola à base de epóxi, tendo estes, as superfícies das unidades previamente regularizadas por raspagem. De acordo com o autor, por serem extremamente finas, as camadas têm influência desprezível nos resultados dos módulos de deformação. Os prismas usuais apresentaram resistência média à compressão axial de 15,7 MPa e os com junta de epóxi resistência média de 10,5 MPa. Esperava-se que os prismas com junta colada apresentassem maior resistência que os prismas usuais, sendo mais próximo da resistência da unidade (18,6 MPa). De acordo com Corrêa (2003), o processo de raspagem da superfície dos tijolos a serem colados foi, provavelmente, realizado de forma indevida, ocasionando concentração de tensões e a ocorrência de excentricidades.

\subsection{Comportamento dos elementos de alvenaria}

A teoria para explicar o mecanismo de ruptura da alvenaria é a proposta por Hilsdorf $^{11}$, em 1969, e difundida por diversos autores como Drysdale e Hamid (1979), Drysdale et al. (1994), Hendry (1998), Ramalho e Corrêa (2003) e Sabbatini (1984).

Conforme Hilsdorf (1969) ${ }^{11}$ apud Sabbatini (1984), "a alvenaria é um material com duas fases, de diferentes resistências e características de deformação. Em geral a resistência à compressão uniaxial e o módulo de elasticidade da argamassa são consideravelmente menores que os correspondentes valores dos tijolos. Portanto, se a argamassa puder se deformar livremente, a sua deformação lateral será maior que a deformação dos tijolos. No entanto, devido à aderência e ao atrito entre a argamassa e o tijolo, a argamassa é confinada. Conseqüentemente um estado interno de tensões se desenvolve, o qual consiste em compressão axial e tração lateral no tijolo e compressão triaxial na argamassa. É unicamente esse estado triaxial que faz com que a alvenaria possa ser submetida a esforços externos que excedem a resistência à compressão uniaxial da argamassa. A ruptura ocorre devido às tensões de tração que ocasionam fissuras verticais nos tijolos, conduzindo ao colapso da alvenaria." Complementa ainda que o colapso da alvenaria, quando carregada uniformemente à compressão, ocorre por

${ }^{11}$ HILSDORF, H.K. (1969). Investigation into the failure mechanism of brick masonry loaded in axial compression. In: DESIGNING ENGINEERING AND CONSTRUCTING WITH MASONRY PRODUCTS. Houston, Gulf. p.34-41. 
meio do desenvolvimento de fissuras de tração paralelas ao carregamento axial ou por colapso devido ao cisalhamento ao longo de algumas linhas de fragilidade. $\mathrm{O}$ tipo de ruína depende se a argamassa é relativamente fraca ou forte em relação à unidade.

Hendry (1998) cita que:

- a falha de separação por tração é iniciada pela deformação restringida das argamassas nas juntas horizontais;

- a resistência à compressão "aparente" da unidade não é a medida direta da resistência da alvenaria, visto que o modo de falha é diferente nas duas situações;

- a argamassa é capaz de resistir a tensões muito mais altas quando sob formas de junta do que nos ensaios uniaxiais. Isso ocorre em virtude da restrição imposta em sua deformação lateral pelas unidades.

Becica e Harris (1983), baseados em diversas pesquisas, relatam que a ruína dos prismas de blocos vazados de concreto com argamassa apenas nas paredes longitudinais é caracterizada pela separação vertical dos septos transversais dos blocos, seguidos da separação das paredes longitudinais em sua espessura. A separação por fissuração vertical dos septos transversais consiste também em um modo de ruína característico da alvenaria com preenchimento total de argamassa nas suas faces horizontais. Fundamentados em ensaios, os autores observaram que a ruína súbita e por cisalhamento diagonal foi a forma predominante de ruína nos ensaios de blocos isolados, ocorrendo na espessura dos septos transversais e paredes longitudinais com separação vertical dos septos transversais extremos evidenciados em todos os espécimes. A Figura 2.6a ilustra a ruína de um bloco submetido à compressão axial.

Nos prismas, as fissuras de tração vertical foram visíveis nos septos transversais entre $50 \%$ e $70 \%$ da força última, seguida do início do esmagamento da argamassa (Figura 2.6b). Também foi notado que uma pequena parte da parede longitudinal (com metade da altura do bloco) pode se destacar. Esse fenômeno é atribuído a uma "punção" que provocará cisalhamento ao invés de uma simples separação. Em relação a este fenômeno, os autores descrevem que "[...] existe um pedaço de concreto na unidade em forma de cunha que perfurará a parede anterior da parede longitudinal, que não está aderida à junta de argamassa, induzindo tensões de tração lateral. A base da cunha está aderida à junta de argamassa, que sofre lascamento 
com o aumento da carga, possibilitando o desprendimento do pedaço anterior da parede longitudinal". O mecanismo descrito está representado na Figura 2.7.

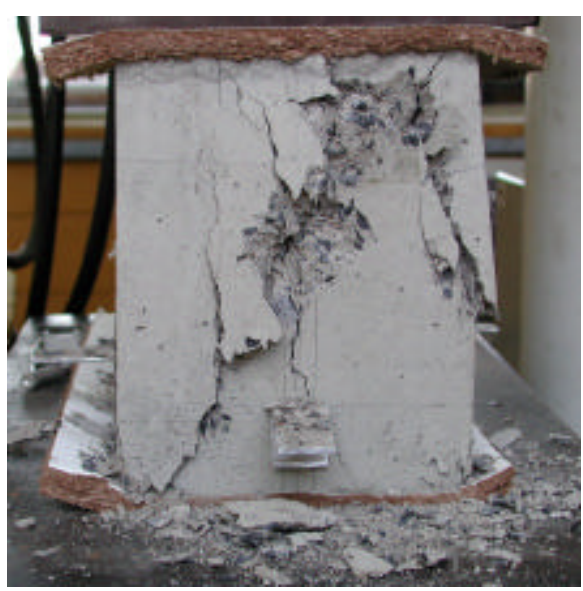

(a)

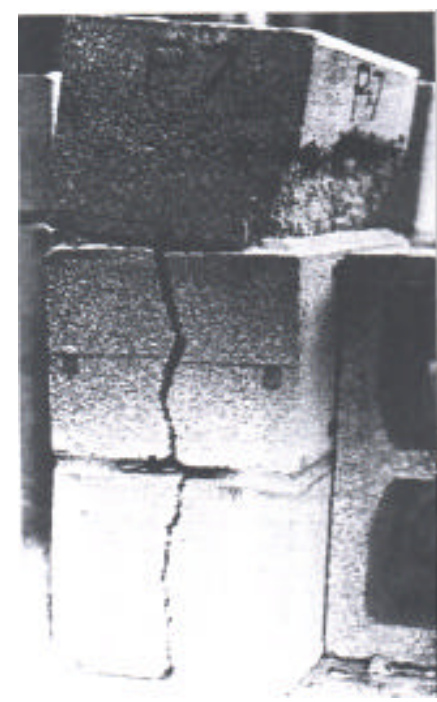

(b)

Figura 2.6 - Ruína do tipo cisalhamento diagonal de um bloco vazado de concreto submetido à compressão axial (a). Situação dos prismas pós-ruína, com separação do septo transversal e destacamento de parte da parede longitudinal (b), Becica e Harris (1983).

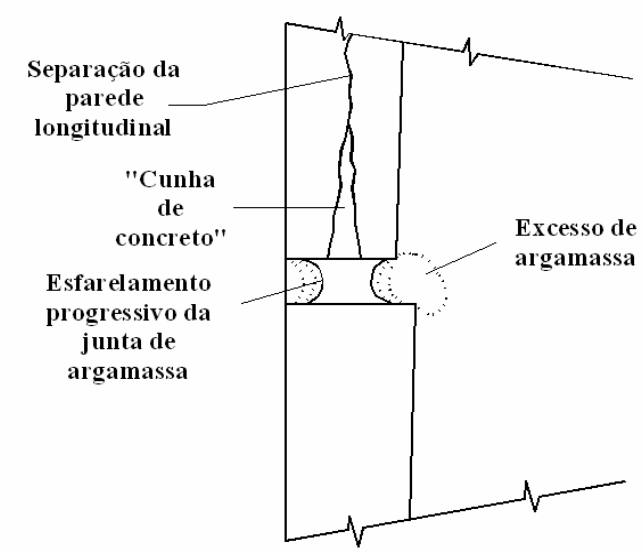

Figura 2.7 - Mecanismo de separação da parede longitudinal, Becica e Harris (1983).

Drysdale e Hamid (1979) afirmam que no caso dos blocos de concreto o tipo de argamassa não tem efeito significativo (como ocorre com elementos cerâmicos), pois há grande compatibilidade entre os materiais - concreto e a argamassa - e ainda a relação entre a altura do bloco e a espessura da junta de argamassa é bem maior que no caso dos tijolos, ocorrendo portanto, menores tensões de tração la teral para a mesma tensão de confinamento da argamassa. Relatam que, durante os ensaios, o bloco de concreto dos prismas é comprimido até cerca de $80 \%$ de sua resistência; nesse nível já ocorreu uma intensa microfissuração e as tensões de tração lateral serão relativamente pequenas se comparadas com as tensões de compressão. 
Analisando as deformações ocorridas no ensaio de prismas de três blocos, Drysdale e Hamid (1979) relatam que o nível de carregamento em que ocorre rápido aumento das deformações devido à tração lateral coincide com o aumento da nãolinearidade da curva tensão-deformação vertical. A não-linearidade dessa curva e o rápido aumento das deformações laterais estão associados ao aumento do coeficiente de Poisson devido à microfissuração do concreto. A Figura 2.8 ilustra tal situação. Com base nos trabalhos de Kupfer et al. (1969) ${ }^{12}$, os autores relatam que a ruína ocorrerá em um ponto situado do lado esquerdo do gráfico da Figura 2.9, onde pequenos aumentos na tensão de compressão correspondem a grandes variações na tensão de tração. As tensões de compressão são mais intensas, embora a ruína ocorra por tensões de tração.

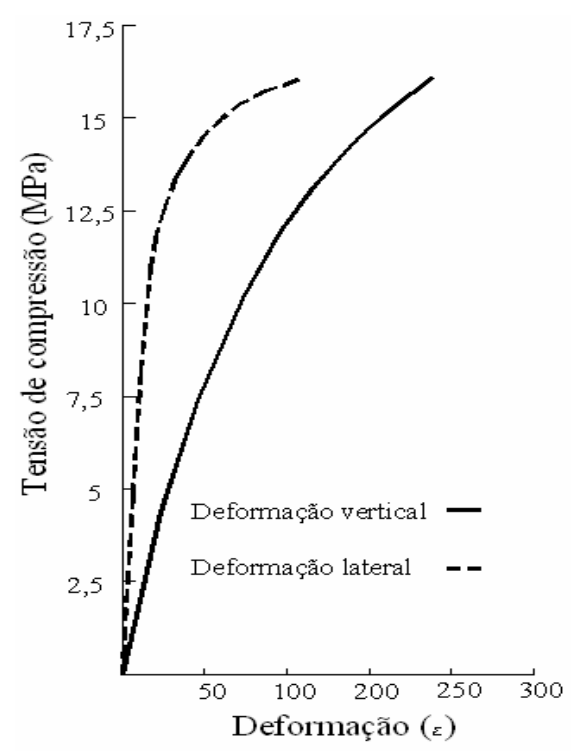

Figura 2.8 - Curvas tensão-deformação dos prismas submetidos à compressão axial, Drysdale e Hamid (1979).

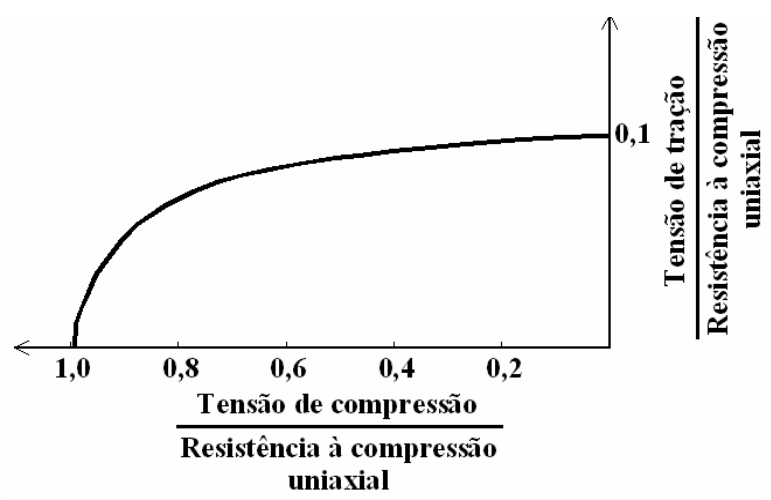

Figura 2.9 - Estado de tensão biaxial do concreto, Kupfer et al. (1969) ${ }^{12}$.apud Drysdale e Hamid (1979).

\footnotetext{
12 KUPFER, H.; HILSDORF, H.K.; RUSCH, H. (1969). Behavior of concrete under biaxial stresses . In:
} ACI Journal, v.66, n.8, p.656-65, aug. 
Nos ensaios com unidades isoladas, e particularmente em relação aos blocos vazados carregados apenas nas paredes longitudinais, Page e Kleeman (1991) afirmam que uma resistência de atrito é desenvolvida nessa zona de contato, restringindo o movimento lateral do elemento, com a placa agindo como se houvesse vínculos entre as duas áreas de contato. Isso resulta em uma carga de fissuração mais alta nos septos transversais, caso a restrição lateral resulte em uma redução dos deslocamentos laterais e das tensões de tração transversal. A modificação na inclinação do capeamento ocasiona tensões mais uniformes de compressão nas paredes laterais e, portanto, uma carga última mais alta (Figura 2.10).

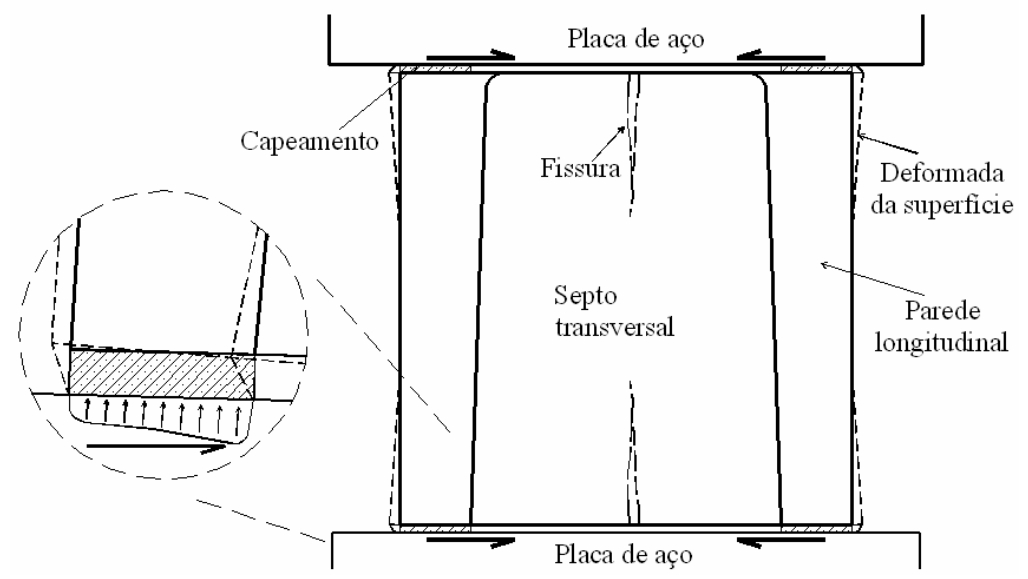

Figura 2.10 - Mecanismo de restrição das placas em unidades vazadas capeadas apenas nas paredes longitudinais, adaptada de Page e Kleeman (1991).

Hendry (1998) descreve o comportamento e o estado de tensão em um quadrante do septo transversal de um bloco vazado com juntas assentadas apenas nas paredes longitudinais (Figura 2.11). A aplicação de uma força de compressão no ponto $A$ resulta em tensões de compressão ao longo da linha $\mathrm{BC}$, na meia altura do bloco. Para que ocorra equilíbrio, um sistema de tensão deve resultar ao longo da linha CD - largura média do bloco - com tensões de tração junto à superfície de topo do bloco.

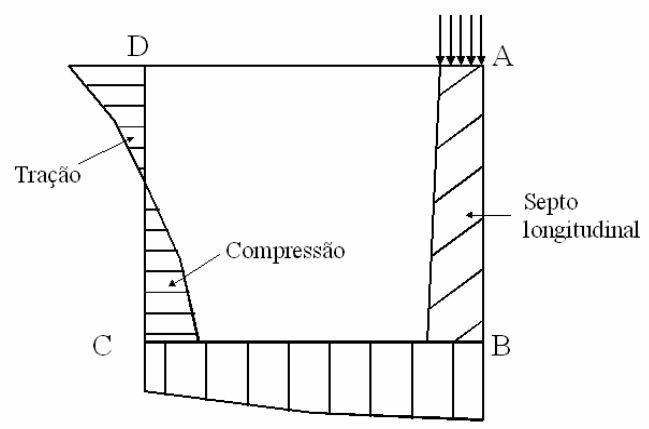

Figura 2.11 - Ruína na alvenaria com argamassa nos septos longitudinais; um quarto de seção do bloco, Shrive (1982) apud Hendry (1998). 


\subsection{Módulo de elasticidade}

Holm (1976) ${ }^{5}$ apud Medeiros (1993) enfatiza que os blocos de concreto devem ter capacidade de se deformar antes que sua ruptura ocorra, pois essa propriedade é altamente desejável para materiais estruturais como o bloco. A deformabilidade, não só dos blocos, como das paredes de alvenaria é também uma importante propriedade para o projeto desse tipo de estrutura.

O módulo de elasticidade e o coeficiente de Poisson são importantes características do bloco de concreto, que não só dizem respeito às deformações da alvenaria, mas também ao seu mecanismo de ruptura. Quanto mais próximas são as propriedades entre os blocos e argamassas, melhor é o aproveitamento do material. $\mathrm{O}$ valor do módulo de elasticidade está atrelado ao valor da resistência do bloco, sendo os maiores valores obtidos com o aumento da resistência.

Não existem ensaios normalizados para a determinação do módulo de elasticidade dos blocos, sendo comumente utilizado o mesmo procedimento dos prismas para sua obtenção. Entretanto, diversos autores utilizam formulações de códigos que tratam do módulo de elasticidade do concreto.

O ACI 530-89 (1995) permite a utilização da Equação (2.12) para o cálculo do módulo secante do concreto com massa específica entre $1442 \mathrm{kgf} / \mathrm{m}^{3}$ e $2483 \mathrm{kgf} / \mathrm{m}^{3}$.

$$
\mathrm{E}_{\mathrm{c}}=0,0428 \sqrt{\mathrm{f}_{\mathrm{c}}} ?_{\mathrm{c}}^{1,5}
$$

$\mathrm{f}_{\mathrm{c}}$ é a resistência à compressão do concreto $(\mathrm{MPa})$;

$\gamma_{\mathrm{c}}$ é a massa unitária do concreto $\left(\mathrm{kgf} / \mathrm{m}^{3}\right)$.

O CEB-FIP (1990) admite que o módulo de elasticidade de concretos de massa específica normal podem ser estimados a partir das suas características à compressão a partir da Equação (2.13).

$$
E_{c}=21500\left(\frac{f_{c m}}{10}\right)^{1 / 3}
$$

$\mathrm{f}_{\mathrm{cm}}$ é a resistência à compressão do concreto $(\mathrm{MPa})$;

Já a NBR 6118 (2003) apresenta a Equação (2.14) para estimar o valor do módulo de elasticidade, quando não forem realizados ensaios e no caso de não existir dados precisos sobre o concreto. 


$$
\mathrm{E}_{\mathrm{ci}}=5600 \mathrm{f}_{\mathrm{ck}}^{1 / 2}
$$

$\mathrm{E}_{\mathrm{ci}}$ é o módulo de elasticidade inicial do concreto;

$\mathrm{f}_{\mathrm{ck}}$ é a resistência característica à compressão do concreto.

A NBR 8522 (1984) cita três tipos de módulos de deformação, definidos a seguir.

a) Módulo tangente de deformação

É a propriedade do concreto cujo valor numérico é a inclinação da reta tangente ao diagrama tensão-deformação especifica em um ponto genérico.

b) Módulo tangente inicial de deformação

Módulo tangente de deformação na origem do diagrama tensão-deformação.

c) Módulo secante de deformação

Propriedade do concreto cujo valor numérico é a inclinação da reta secante ao diagrama tensão-deformação passando pelos pontos referente à tensão de $0,5 \mathrm{MPa} \mathrm{e}$ uma tensão considerada.

O ACI 530-92 (1995) admite que o módulo de elasticidade da alvenaria de unidades de concreto possa ser obtido em função da resistência do bloco e da argamassa utilizando tabela ou por meio de ensaios com prismas, a partir da inclinação da reta que une os pontos correspondentes a 5\% e 33\% da máxima resistência à compressão.

O módulo de elasticidade e a curva tensão-deformação são obtidos geralmente por meio de ensaios com prismas, e segundo relatam Drysdale et al. (1994), ao se alcançar em torno de $50 \%$ da tensão máxima a não linearidade já é evidente. Apesar dos prismas representarem melhor o comportamento da alvenaria, os autores citam que ensaios com unidades isoladas para esse fim são realizados para aquisição de informações mais completas de suas características.

Mohamad (1998) e Romagna (2000) utilizaram em seus trabalhos a Equação (2.13) para o cálculo do módulo de elasticidade secante dos blocos de concreto. Juste (2001) determina o módulo de elasticidade dos blocos a partir do gráfico tensãodeformação, utilizando a equação de uma parábola ajustada à curva obtida experimentalmente. Para medição dos deslocamentos longitudinais posicionaram-se transdutores indutivos, com base de medida de $154 \mathrm{~mm}$, no centro do vazio do bloco.

Becica e Harris (1983) fizeram medições da deformação longitudinal em blocos isolados e nos blocos centrais dos prismas de três blocos submetidos à 
compressão. Nesses elementos foram colocados LVDT's (Linear Variable Differential Transformers) em cinco pontos da parede longitudinal, sendo dois nas extremidades, dois afastados cerca de $10 \mathrm{~cm}$ para cada um dos lados a partir do septo transversal central e um na região central. Foram também colocados dois LVDT's nas extremidades das paredes transversais. A Figura 2.12 ilustra a instrumentação (a) e as deformações obtidas no bloco isolado (b) e no bloco central do prisma de três blocos (c).

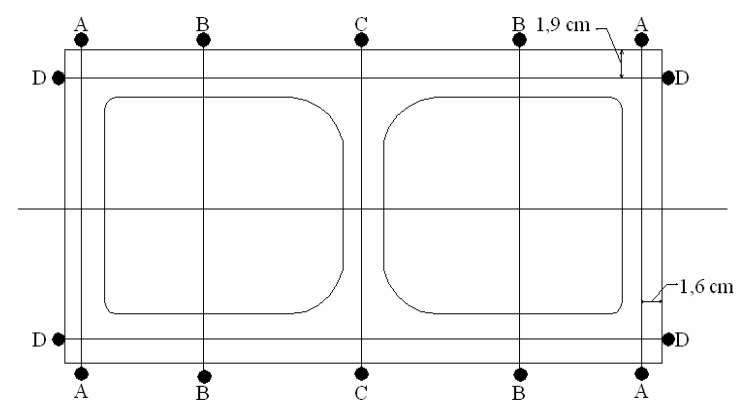

(a)

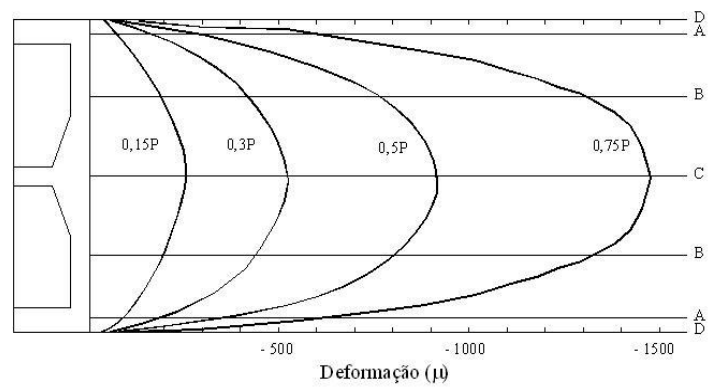

(b)

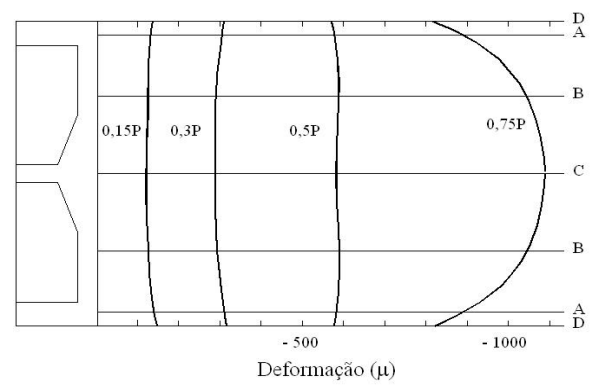

(c)

Figura 2.12 - Localização dos transdutores nos blocos e prismas (a). Deformações em três níveis de tensão: no bloco isolado (b) e no bloco central do prisma (c), adaptada de Becica e Harris (1983).

Nas unidades isoladas foi observado que para todos os níveis de carga analisados ocorreram variações das deformações nas extremidades em relação ao centro obtendo-se, neste ponto, a maior deformação. Ocorre também grande variação nas deformações quando se aumenta o carregamento, sendo sempre a região central a mais sensível a essas variações. Já em relação aos prismas, analisando-se apenas o bloco central, nota-se que o nível de deformação para uma dada carga é praticamente constante. Isto é visto com maior evidência a $30 \%$ da força última. Quando se atinge $75 \%$ da força última nota-se uma dispersão dos valores, obtendo-se as maiores deformações em direção ao centro do bloco.

Como visto, a restrição ocasionada pelas placas causa diferença nos resultados da resistência à compressão, principalmente quando ensaiadas unidades isoladas. A curva tensão-deformação também é alterada. A Figura 2.13 apresenta a comparação 
entre duas curvas tensão-deformação para blocos vazados de concreto, uma obtida por meio de ensaios com capeamento rígido e a outra ensaiada com placa-escova.

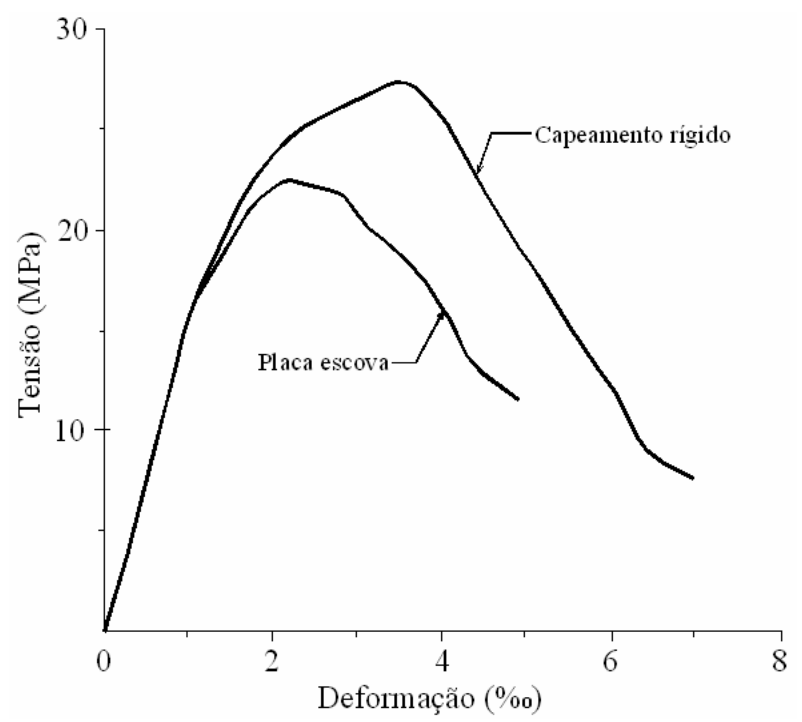

Figura 2.13 - Curva tensão-deformação típica para blocos vazados de concreto, Drysdale et al. (1994).

Drysdale et al. (1994) citam que a forma da curva, particularmente para níveis mais altos de tensão, é mais sensível ao tipo de restrição imposta pelas placas. A nãolinearidade começa a ser mais perceptível entre 35\% e 50\% da resistência da unidade.

Por fim, Juste (2001) ressalta a necessidade de uma norma específica para a obtenção do módulo de elasticidade das unidades e componentes de alvenaria, alertando para o fato de não haver nenhum método de ensaio padronizado. Relata ainda que os valores obtidos são afetados por diversos fatores, tais como velocidade de carregamento, intensidade de carregamento, dimensões dos corpos-de-prova, inviabilizando assim a comparação direta dos resultados com os de outros pesquisadores. 


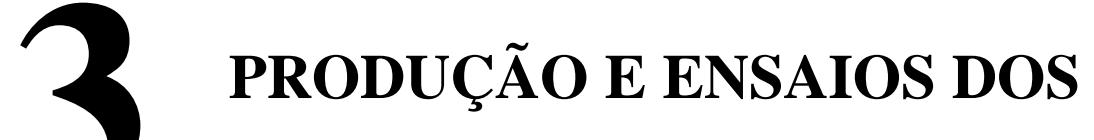 ELEMENTOS DE CONCRETO}

O presente capítulo descreve a metodologia utilizada na produção e no ensaio dos blocos vazados de concreto, prismas e seus respectivos corpos-de-prova. Os blocos de concreto, além de ensaiados isoladamente, destinam-se à confecção de prismas com juntas de adesivo à base de epóxi. A idéia central da produção desses elementos ${ }^{1}$ é moldar seqüencialmente os blocos e corpos-de-prova com concreto da mesma betonada, posteriormente adensados, curados e ensaiados da mesma maneira, correlacionando as suas propriedades mecânicas. Detalham-se os ensaios e caracteriza-se o comportamento dos elementos durante tal procedimento. Realizam-se ensaios à compressão e à tração com os blocos vazados de concreto e corpos-de-prova; já os prismas são submetidos apenas a ensaios de compressão.

\subsection{Descrição do concreto utilizado}

Para facilitar a moldagem dos blocos e paralelamente dos corpos-de-prova optou-se por empregar o concreto plástico.

Moldam-se elementos com concreto em três níveis de resistência nominal (10, 20 e $30 \mathrm{MPa}$ ), correlacionando as propriedades mecânicas dos blocos e dos corpos-deprova. Cada nível de resistência é relacionado a um determinado grupo (10, 20 ou 30), definido pelo valor da resistência média (aos 14 dias) obtida por meio de ensaios à compressão em corpos-de-prova cilíndricos, de 10 x $20 \mathrm{~cm}$, a um passo de carga de 2,4 kN/s. A Tabela 3.1 apresenta os traços utilizados na confecção do concreto de cada grupo de resistência. A definição dos traços não considera as restrições normativas a respeito da relação água-cimento prescritas por diversas normas, pois os blocos e CPs

\footnotetext{
${ }^{1}$ Utiliza-se, no presente trabalho, a palavra elemento na refrência a um grupo de blocos, prismas e/ou corpos-de-prova sem que haja a necessidade de distinção entre eles.
} 
são produzidos seqüencialmente sob as mesmas condições com concreto da mesma betonada e tal relação não influencia na correlação dos resultados.

Tabela 3.1 - Composição dos traços de concreto para cada nível de resistência.

\begin{tabular}{cccc}
\hline & \multicolumn{3}{c}{ Nível de resistência (MPa) } \\
& 10 & 20 & 30 \\
\hline Traço em massa $^{1}$ & $1: 4,2: 3: 1,2$ & $1: 3,3: 3,8: 1$ & $1: 2: 2,7: 0,67$ \\
Traço em volume $^{1}$ & $1: 5: 3,3: 3,7$ & $1: 3,9: 4,1: 3,2$ & $1: 2,4: 2,9: 2,1$ \\
\hline cimento: areia: brita: água & &
\end{tabular}

\subsubsection{Caracterização dos materiais empregados na fabricação do concreto}

Utiliza-se o Cimento Portland de Alta Resistência Inicial (CP V - ARI) Plus, da marca CIMINAS. A necessidade da realização de ensaios em um curto prazo de tempo (próximo aos 14 dias) fundamenta a escolha desse tipo de cimento.

Como agregado miúdo utiliza-se a areia natural do tipo quartzosa, proveniente do rio Mogi-Guaçu, sendo o agregado graúdo de origem basáltica da região de São Carlos. Realizaram-se ensaios de caracterização dos agregados no Laboratório de Materiais Avançados à Base de Cimento (LmABC) da EESC-USP, seguindo-se as prescrições das seguintes Normas Brasileiras: NBR 7211 (1983) e NBR $7217(1987)^{2}$ (referentes à granulometria) e NBR 7251 (1982) e NBR 9776 (1987) (que prescrevem os ensaios para determinação da massa unitária e da massa específica).

Caracterizoutse a areia como sendo da zona 3 (areia média), com diâmetro máximo de 2,4 mm e módulo de finura de 2,34; o agregado graúdo caracterizado como de graduação 0, possui diâmetro máximo de 9,5 mm e módulo de finura igual a 5,33.

A massa específica de um agregado é a relação entre a sua massa e o seu volume, não levando em consideração os vazios permeáveis à água. Já a massa unitária de um agregado é a relação entre a sua massa e o seu volume sem compactar, considerando-se como volume também os vazios entre os grãos. Segundo a ABCP (2000b), a massa unitária é o parâmetro tido como próprio para transformar a massa dos agregados em volume, ou vice-versa, durante a dosagem do concreto.

\footnotetext{
2 Associação Brasileira de Normas Técnicas (2001). NM248: Agregados - Determinação da composição granulométrica. Rio de Janeiro.
} 
As massas específicas da areia e da brita valem, respectivamente, $2,63 \mathrm{~g} / \mathrm{cm}^{3} \mathrm{e}$ $2,87 \mathrm{~g} / \mathrm{cm}^{3}$, ao passo que o valor da massa unitária da areia é $1,5 \mathrm{~g} / \mathrm{cm}^{3}$ e da brita 1,32 $\mathrm{g} / \mathrm{cm}^{3}$.

\subsection{Etapas do processo de produção dos elementos}

A cada concretagem moldam-se os elementos com concreto de um determinado grupo, destinados a um tipo específico de ensaio (com blocos, prismas ou corpos-de-prova).

No dia subseqüente à concretagem, ocorre a desforma dos elementos e o início do processo de cura, na câmara úmida. Os elementos são retirados da câmara úmida após 7 dias. Esse período, considerado como o mínimo necessário para uma cura satisfatória, é determinado em função das atividades realizadas até o dia dos ensaios: marcação e execução da instrumentação, capeamento dos elementos e construção dos prismas.

Os ensaios dos elementos ocorrem geralmente entre 13 e 15 dias após a concretagem, ressaltando-se que se ensaiam os elementos de um mesmo grupo no mesmo dia.

\subsection{Blocos de concreto}

O bloco vazado de concreto possui dimensões externas de 14 x 19 x $39 \mathrm{~cm}$ (largura $\mathrm{x}$ altura $\mathrm{x}$ comprimento), com área bruta de $546 \mathrm{~cm}^{2}$ e área líquida de aproximadamente $306,63 \mathrm{~cm}^{2}$. A produção destina-se aos ensaios desses elementos isoladamente, caracterizando o seu comportamento e comparando suas propriedades mecânicas com as propriedades do concreto que o constitui.

\subsubsection{Produção}

A produção dos blocos de concreto difere do processo comercialmente utilizado em que o concreto é vibro-prensado. Idealizou-se um novo procedimento de produção em laboratório tendo como principal objetivo assegurar a resistência desejável (diante de um processo de alta qualidade) e a precisão geométrica dos diversos blocos produzidos. 
Definiu-se a geometria dos blocos a partir das diversas geometrias encontradas nos blocos comerciais e utilizados em pesquisas científicas, buscando que não diferissem significativamente destas. Entretanto, optou-se por não variar a espessura, ao longo da altura, das paredes longitudinais e septos transversais como pode ser observado na Figura 3.1a.

Utilizam-se fôrmas metálicas para a produção dos blocos de concreto, as quais delimitam suas dimensões externas. Os vazios do bloco são definidos pela inserção de dois prismas de EPS (poliestireno expandido) que são enrijecidos por uma barra de travamento com hastes metálicas aparafusada na parte superior da fôrma, e extraídos logo após a desforma. As paredes laterais são aparafusadas entre si e com a base da fôrma, permitindo a completa rigidez do conjunto. O detalhe da fôrma e a utilização dos EPS's são apresentados na Figura 3.1b.

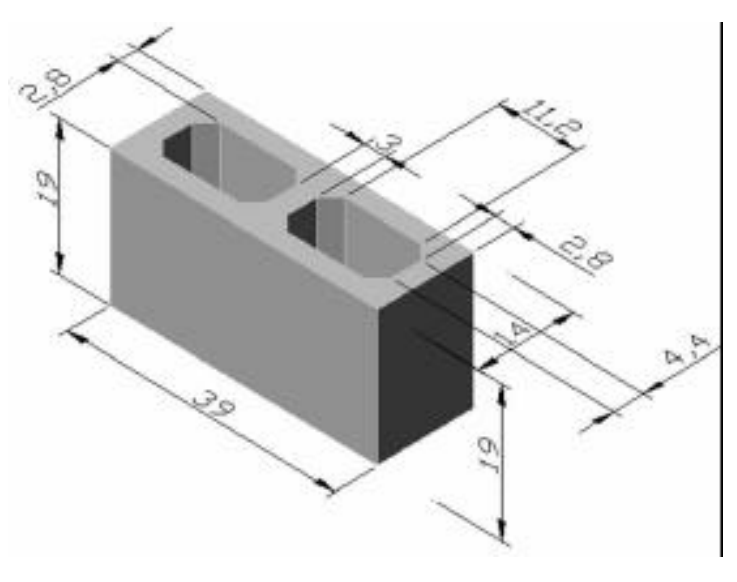

(a)

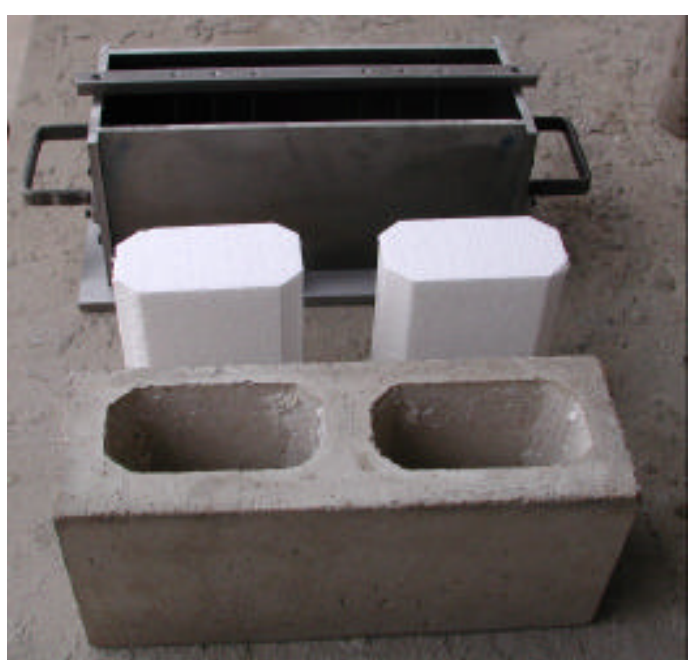

(b)

Figura 3.1 - Detalhe das dimensões (em centímetros) do bloco vazado de concreto (a). Fôrma metálica, prismas de EPS e o bloco vazado de concreto após a desmoldagem (b).

Realizou-se ensaio com os prismas de EPS para avaliar sua capacidade de absorção quando imersos por vinte e quatro horas em água. Em duas amostras, esse material apresentou absorção média de $260 \%$ em relação ao seu peso inicial $(22,7$ g), considerando-se, portanto, desprezível a quantidade de água absorvida em relação ao traço original quando estes são utilizados na fabricação dos blocos de concreto.

A concretagem inicia-se após a verificação do perfeito travamento da fôrma e posicionamento dos EPS's, como mostra a Figura 3.2. É medida a uniformidade do abatimento do concreto por meio do ensaio de determinação da consistência pelo abatimento do tronco de cone, segundo a NBR 7223 (1992). Nos três grupos de resistência o abatimento varia entre $20 \mathrm{~mm}$ e $50 \mathrm{~mm}$. Preenche-se uma fôrma a cada 
vez, que desde o início do processo está sobre uma mesa vibratória adensando o concreto. Com o completo preenchimento da fôrma, impõe-se uma vibração mais intensa, por aproximadamente 20 segundos, até o aparecimento de bolhas de ar na superfície da fôrma. Dá-se, seqüencialmente, prosseguimento à moldagem dos demais blocos.

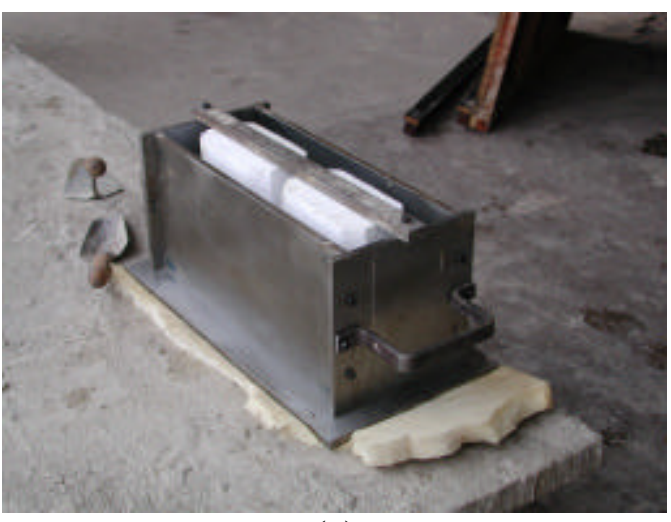

(a)

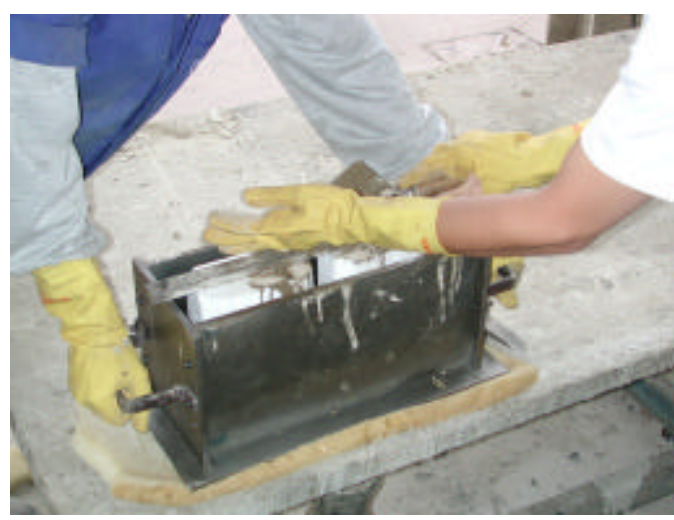

(b)

Figura 3.2 - Fôrma preparada para concretagem sobre a mesa vi bratória (a). Concretagem e adensamento dos blocos de concreto (b).

A Figura 3.3 ilustra os blocos após a concretagem, que ainda recebem acabamento final no seu topo permanecendo em repouso até a desforma no dia seguinte.

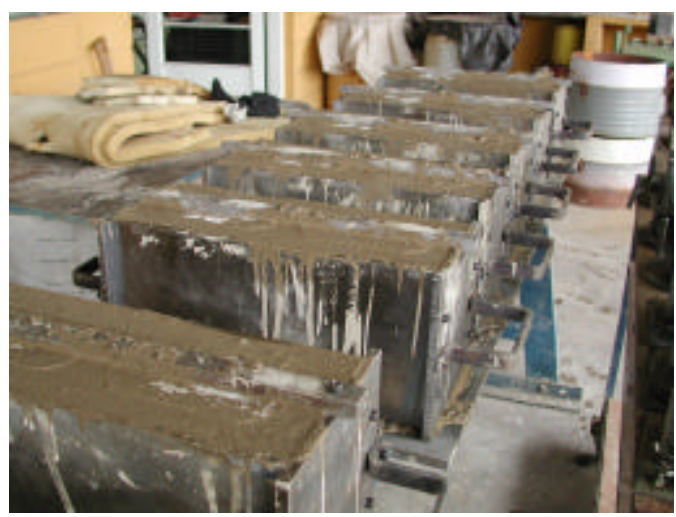

Figura 3.3 - Blocos após a concretagem antes do acabamento final do topo.

Após a desforma e retirada dos EPS's os blocos têm todas as suas dimensões conferidas, determinando-se a área líquida efetiva dos blocos de concreto e aferindo-se a qualidade da concretagem.

O capeamento tem como objetivo regularizar as superfícies de carregamento do bloco. Optou-se pela utilização do enxofre como material de capeamento dos blocos de concreto, inclusive daqueles que compõem os prismas. A agilidade na execução do capeamento e a rigidez do enxofre endurecido são fatores que influenciaram a escolha. A alta rigidez, comparada com a dos outros materiais comumente utilizados como 
capeamento, permite a simplificação das condições de contorno em simulações numéricas. Apresentam-se na Figura 3.4 os blocos e corpos-de-prova capeados com enxofre.

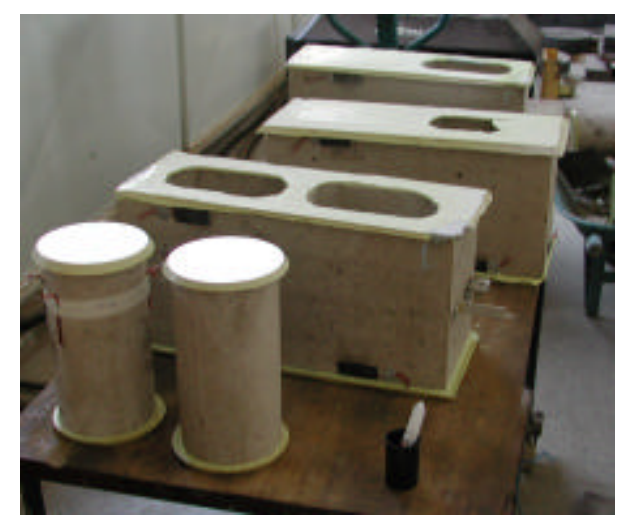

Figura 3.4 - Blocos e corpos-de-prova capeados com enxofre.

\subsubsection{Detalhamento dos ensaios.}

Os ensaios à compressão dos blocos de concreto foram realizados na máquina universal de ensaios mecânicos, com capacidade de 2500 kN, servo-hidráulica, de marca Instron, controlada por computador. O equipamento possui controle de deslocamento permitindo a obtenção de boa parte do ramo descendente da curva tensãodeformação e a completa caracterização do material. A ruptura brusca do elemento muitas vezes é evitada. Utiliza-se, durante todo o ensaio, taxa de deslocamento de 0,005 $\mathrm{mm} / \mathrm{s}$, que corresponde a uma deformação de aproximadamente $25 \mu \varepsilon / \mathrm{s}$.

Sobre o capeamento de enxofre foi colocada uma placa de aço com dimensões de 393,5 x 193,5 x 25 mm com objetivo de uniformizar a distribuição da força aplicada pelo pistão da máquina, que possui diâmetro de 294 mm, conforme ilustra a Figura 3.5.

O fator K, pesquisado por Atkinson (1991) em diversas normas, varia entre 0,33 e 1 . Nesse esquema de ensaios o fator vale 0,34 ; a espessura da placa satisfaz ainda a prescrição da NBR 7184 (1992), que estabelece ainda 25 mm como o valor mínimo.

Realizaram-se ensaios para caracterização da resistência dos blocos à tração, comparando os valores com a resistência à compressão de blocos e corpos-de-prova, bem como com a resistência à tração de corpos-de-prova. Nesses ensaios, em que não se dispôs nenhum tipo de instrumentação nos elementos, moldaram-se 40 blocos e 70 corpos-de-prova cilíndricos $(10$ x $20 \mathrm{~cm}$ e 15 x $30 \mathrm{~cm})$ dos três grupos de resistência. Os ensaios de resistência à compressão e à tração dos blocos foram realizados na máquina 
de ensaios ELE, com capacidade de 2000 kN. A velocidade nos ensaios de compressão e tração foi de $3,5 \mathrm{kN} / \mathrm{s}$ e $1,2 \mathrm{kN} / \mathrm{s}$, respectivamente.

Por não existir nenhuma norma brasileira que descreva os procedimentos para o ensaio de resistência à tração de blocos, utilizou-se a norma americana ASTM C 1006 (1996).

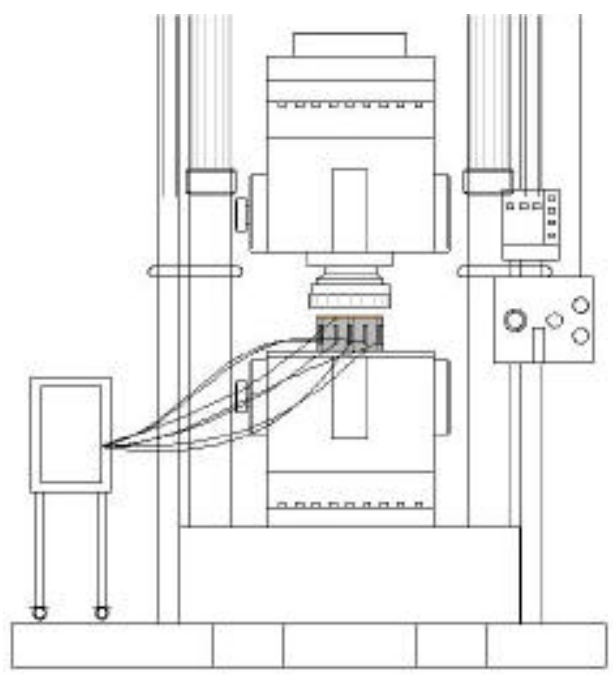

(a)

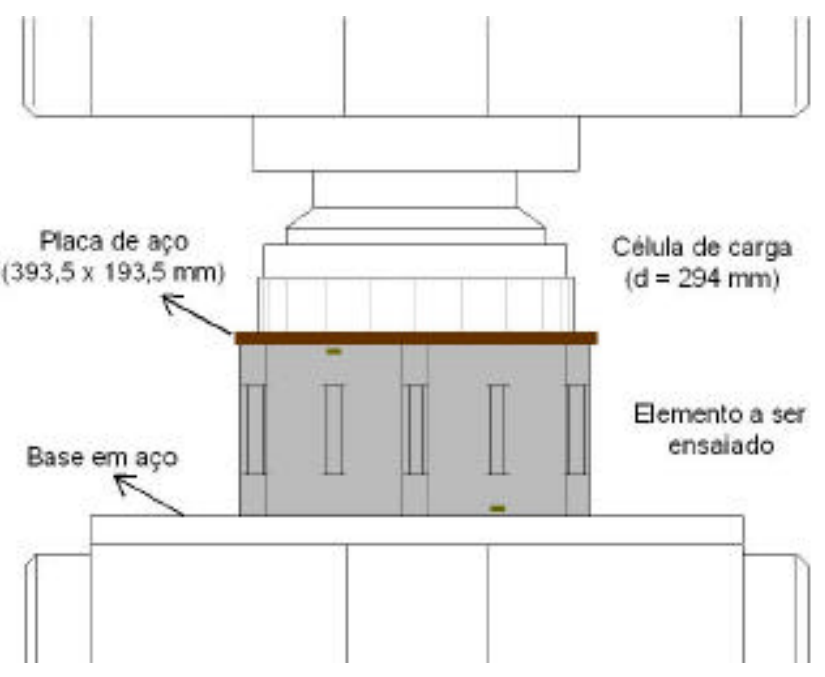

(b)

Figura 3.5 - Sistema de ensaio e de aquisição de dados (a). Detalhe do ensaio de blocos vazados de concreto (b).

O ensaio é realizado com a aplicação da força de compressão, transmitida por barras cilíndricas, em uma linha ao longo da superfície horizontal da unidade, que resultará em tensões de tração ao longo da altura.

A ASTM C 1006 (1996) apresenta a Equação (3.1) para o cálculo da resistência à tração indireta das unidades de alvenaria.

$$
\mathrm{T}=\frac{20 \mathrm{P}}{\mathrm{pLH}}
$$

T é a resistência à tração indireta (MPa);

P é a força máxima aplicada pela máquina $(\mathrm{kN})$;

L é a distância em que é aplicada à força na unidade (cm);

H é a altura da unidade $(\mathrm{cm})$.

Capuzzo Neto (2003) realizou ensaios à tração indireta em blocos vazados cerâmicos, de escala reduzida, com a aplicação da força na região central do vazio do bloco. Justifica, baseado em simulações numéricas, que essa é a posição mais favorável, por só existirem paredes ortogonais ao plano de carregamento. Dessa forma, obtém-se o 
valor da tensão máxima de tração muito próximo ao encontrado, utilizando-se Equação (3.1). Explica ainda que na região do septo ocorrem perturbações de tensões provocando um distanciamento desses valores.

A ASTM C 1006 (1996) enfatiza que o coeficiente de variação dos resultados é alto, apresentando média de $20 \%$ para grupos de cinco amostras.

Para cada grupo ensaiam-se cinco blocos à tração indireta, com a força aplicada e apoio apenas na região central de um dos vazios do bloco. O esquema do ensaio está apresentado na Figura 3.6. A velocidade do ensaio é de 1,2 kN/s.

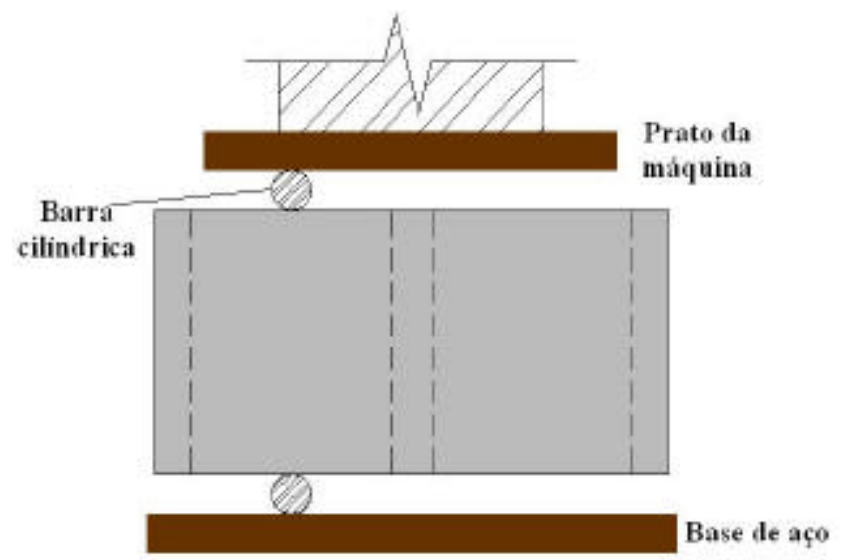

Figura 3.6 - Esquema dos ensaios à tração indireta dos blocos vazados de concreto.

\subsubsection{Instrumentação}

A fim de determinar os deslocamentos e deformações ocorridas no bloco, utilizaram-se 4 tipos de instrumentos de medição: extensômetros removíveis, transdutores de deslocamento, extensômetros elétricos de resistência e relógios comparadores. A resolução do extensômetro removível e do transdutor de deslocamento é de $0,001 \mathrm{~mm}$, enquanto que a do extensômetro elétrico e do relógio comparador valem, respectivamente, $1 \mu$ e $0,05 \mathrm{~mm}$. As capacidades de leitura dos extensômetros removíveis, transdutores de deslocamento e relógios comparadores são de 1,5 mm, 10 mm e 100 mm, respectivamente. Todos os instrumentos de medição são conectados a um sistema de aquisição de dados computadorizado. A instrumentação está detalhada na Figura 3.7.

Medem-se os deslocamentos verticais por meio dos extensômetros removíveis localizados ao longo do comprimento da parede longitudinal e no septo transversal do bloco. Com essa distribuição de instrumentação, analisa-se a influência exercida pelos septos e vazios dos blocos na deformação destes. A fim de verificar a existência de excentricidades no ensaio, repete-se a instrumentação nas regiões opostas do bloco 
sempre que possível. Obtêm-se os deslocamentos transversais no septo transversal e na parede longitudinal com auxílio dos transdutores de deslocamento. A utilização de extensômetros elétricos de resistência e relógios comparadores tem como objetivo analisar as deformações e deslocamentos no topo e base dos blocos, que são influenciados pelo tipo de material de capeamento utilizado.

De acordo com Takeya (2001), os relógios comparadores e os extensômetros removíveis são destinados à medição dos deslocamentos lineares, diferindo apenas quanto à forma de medição da grandeza: mecânica e por variação da resistência, respectivamente. Já o extensômetro elétrico de resistência mede diretamente as deformações com grande precisão e sensibilidade, porém são sensíveis à variação de umidade e de temperatura. Para medição dos deslocamentos verticais optoutse pelos extensômetros removíveis pela maior facilidade de fixação nos elementos ensaiados. Nas demais medições, os instrumentos foram escolhidos de acordo com a disponibilidade do laboratório.

(2)

(3)

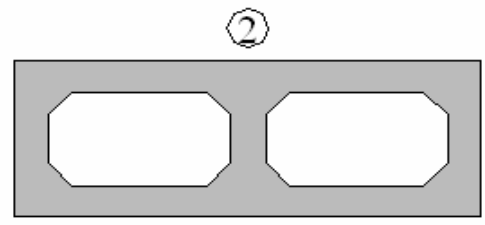

(1)

\section{$\underline{\text { Bases de medida }}$}

Extensôm etro removível: $100 \mathrm{~mm}$

Transdutor de deslocamento (b): $90 \mathrm{~mm}$

Transdutor de deslocamento (c): $50 \mathrm{~mm}$

Extensôm etro elétrico de resistência: $10 \mathrm{~mm}$

(a)
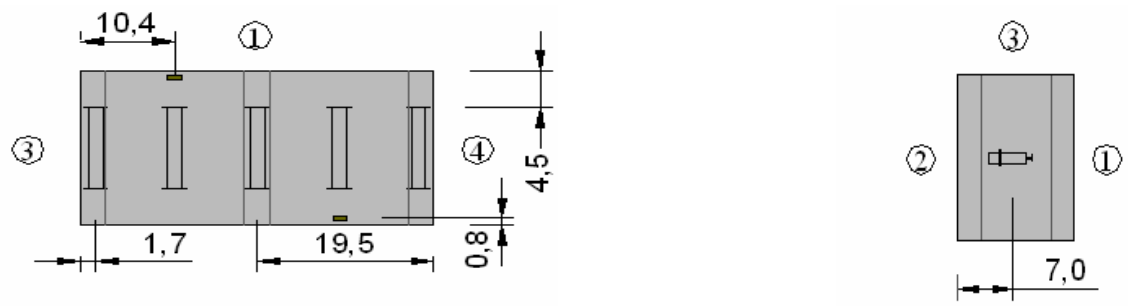

\section{Transdutor}

de Extensômetro

deslocamento

removível

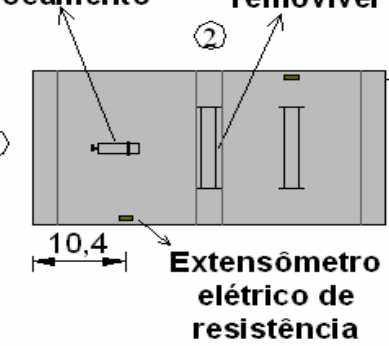

(b)

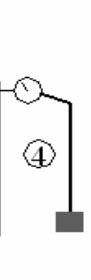

Relógio comparador

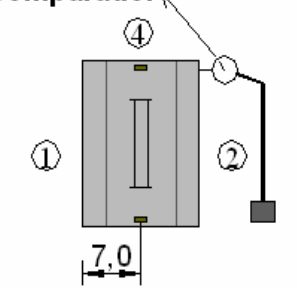

(c)

Figura 3.7 - Vista superior do bloco de concreto e bases de medida dos instrumentos (a). Detalhamento da instrumentação utilizada nos ensaios de blocos de concreto, paredes longitudinais (b) e septos transversais (c). 
A Figura 3.8 apresenta a referida instrumentação posicionada nos blocos durante os ensaios.

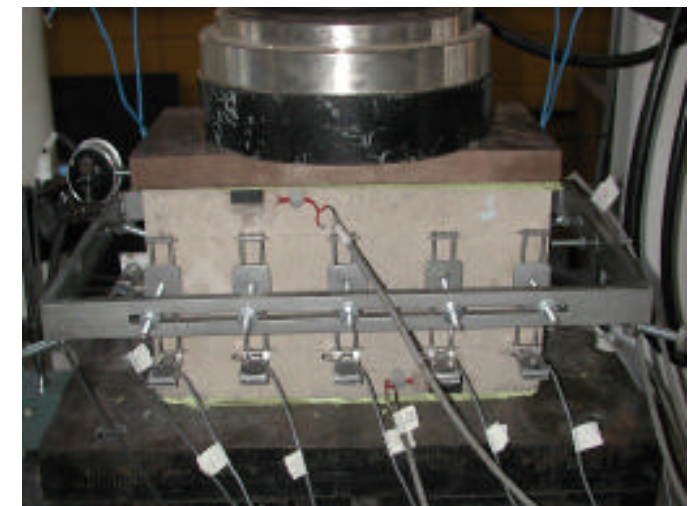

(a)

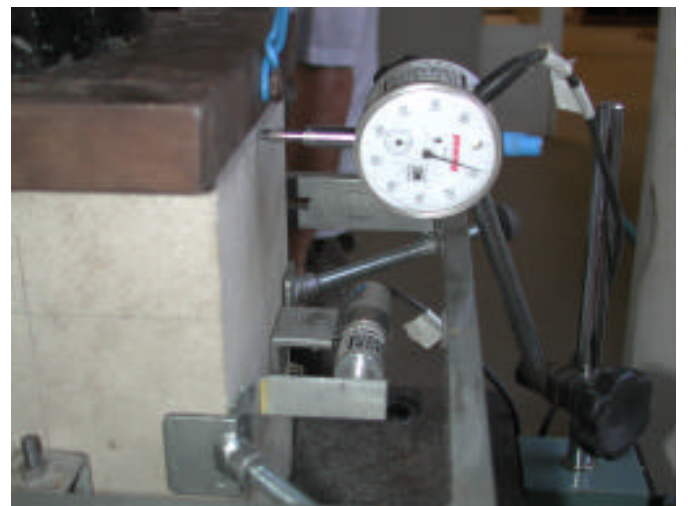

(b)

Figura 3.8 - Instrumentação utilizada nos ensaios de blocos isolados: extensômetros removíveis e extensômetros elétricos na parede longitudinal (a) e relógio comparador e transdutor de deslocamento no septo transversal (b).

A Figura 3.9 apresenta o ensaio à tração indireta dos blocos vazados de concreto em que se obteve apenas a força de ruína.

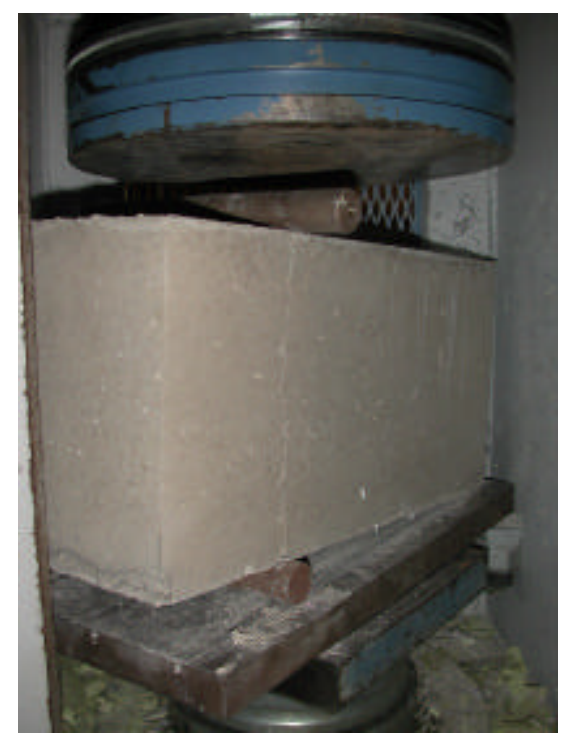

Figura 3.9 - Ensaio à tração indireta do bloco vazado de concreto.

\subsubsection{Comportamento dos blocos}

Os blocos apresentam comportamento semelhante durante os ensaios de compressão. A única diferença relevante ocorre com os blocos do grupo 30, que após atingirem a força máxima, sem o aparecimento de grande fissuração e deformações, rompem de forma súbita.

Os blocos não apresentam, até a ruína, deformações perceptíveis, entretanto, a fissuração externa é notada comumente a partir de $80 \%$ da força máxima. O intervalo de 
maior freqüência de surgimento das fissuras é entre $85 \%$ e $90 \%$, porém identificou-se fissuração ao nível de $70 \%$ em um dos blocos dos grupos 20 e 30.

As fissuras surgem na parede longitudinal do bloco, geralmente dispostas na direção horizontal, levando ao surgimento de lascas na camada superficial do bloco, inclinando-se em direção aos septos transversais. A ruína dos blocos é caracterizada pelo cisalhamento diagonal, ilustrado na Figura 3.10. Esse tipo de ruína dá-se em consequiência da forma geométrica do bloco, devido à relação entre as dimensões da base e altura, o que induz a intensa ação do confinamento exercido pelas placas utilizadas no ensaio dispostas sobre o bloco.

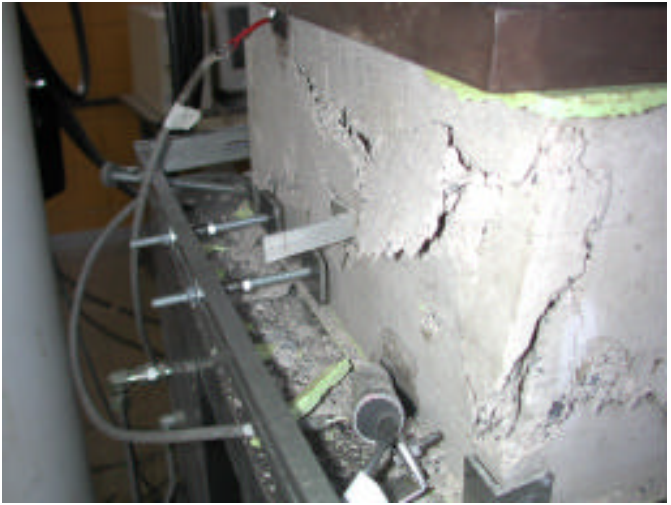

(a)

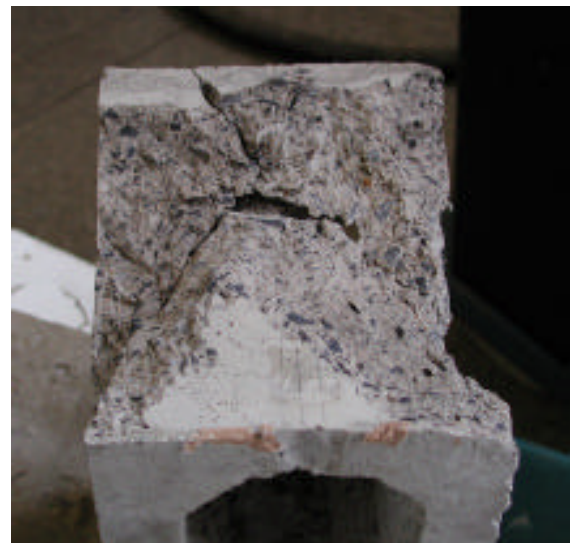

(b)

Figura 3.10 - Configuração da ruína do bloco: fissuras inclinadas e destacamento do concreto na parede longitudinal (a) e septo transversal após ruína (b).

Realizaram-se os ensaios à tração dos blocos sem controle de deformação, não sendo possível a observação do aparecimento de fissuras. A ruína, de forma súbita, ocorre ao se atingir a força máxima de ensaio. Os blocos apresentam fissuras verticais nas duas paredes longitudinais, abaixo do ponto de aplicação da força, que induz a separação do bloco em partes distintas. De forma geral, nos blocos do grupo 10 e 20, as fissuras foram evidentes em ambas paredes longitudinais, contudo, sem a separação efetiva do bloco. Já os blocos do grupo 30, ao término do ensaio, estavam separados em duas partes. A Figura 3.11 apresenta a configuração da ruína dos blocos. 


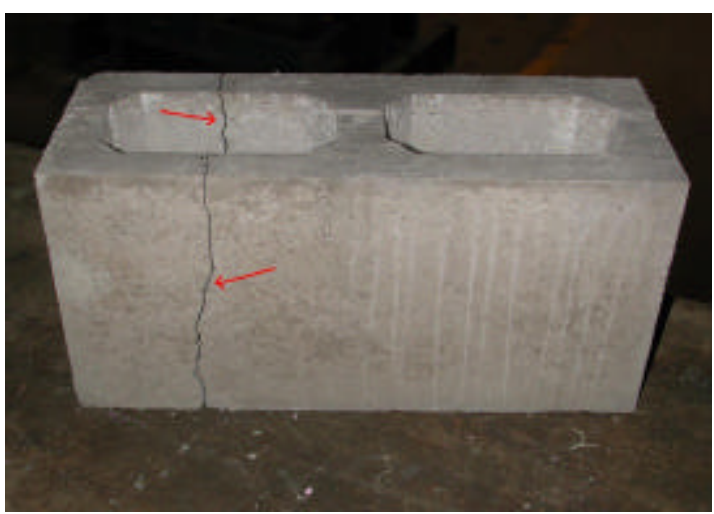

(a)

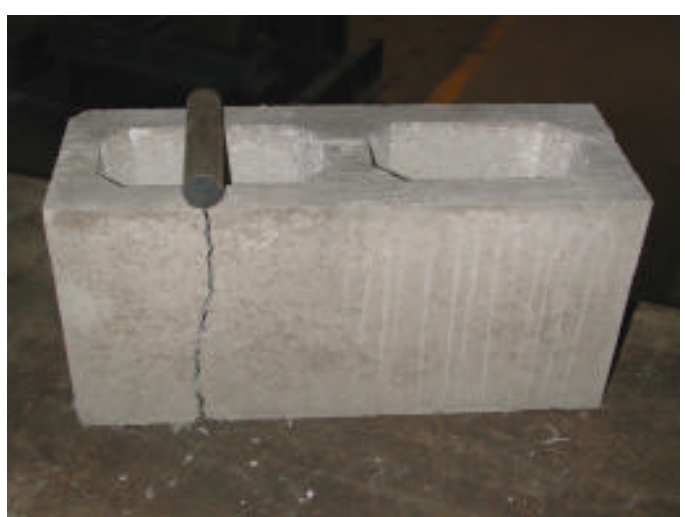

(b)

Figura 3.11 - Fissura interna e externa na parede longitudinal ${ }^{3}$ (a) e separação do bloco abaixo da linha de aplicação da força.

\subsection{Corpos-de-prova}

Paralelamente à produção dos blocos são moldados corpos-de-prova com 5 geometrias e dimensões distintas: 3 cilíndricos $(5 \times 10 \mathrm{~cm}, 10 \times 20 \mathrm{~cm}$ e 15 x $30 \mathrm{~cm}), 1$ cúbico $(10 \times 10 \times 10 \mathrm{~cm})$ e um prismático $(3 \times 3 \times 6 \mathrm{~cm})$. Realizam- se ensaios com esses elementos a fim de caracterizar as propriedades mecânicas do concreto utilizado na moldagem de blocos e prismas. A escolha dessas geometrias de corpos-de-prova se deve à falta de padronização dos CPs encontrados em diversas pesquisas e à procura de uma geometria que melhor represente essas propriedades mecânicas. Como os CPs cilíndricos têm sua utilização consolidada em relação ao concreto optou-se por variar as suas relações altura-diâmetro. Algumas normas internacionais também utilizam os cubos como corpos-de-prova em alguns ensaios. Os CPs prismáticos foram escolhidos por terem espessura próxima às utilizadas nas paredes longitudinais e septos dos blocos.

\subsubsection{Produção}

$\mathrm{Na}$ produção destinada aos ensaios de blocos isolados utilizam-se todas as geometrias e dimensões disponíveis de corpos-de-prova, entretanto, na produção destinada aos ensaios de prismas, moldam-se apenas corpos-de-prova cilíndricos de dimensões 10 x $20 \mathrm{~cm}$ e 15 x $30 \mathrm{~cm}$. As fôrmas utilizadas na moldagem dos corpos-deprova são apresentadas na Figura 3.12.

3 Algumas fissuras não são visíveis, após a inserção do arquivo de imagem no texto, em virtude da qualidade da foto e/ou de sua pequena abertura. Nesses casos, as fissuras foram escurecidas e indicadas por uma seta vermelha. 


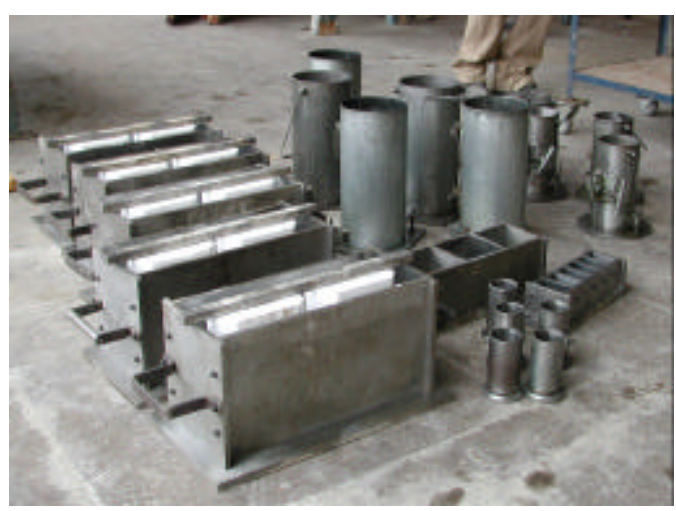

Figura 3.12 - Fôrmas utilizadas na moldagem dos diferentes tipos de corpos-de-prova e dos blocos de concreto.

A Tabela 3.2 apresenta a quantidade de corpos-de-prova moldados nas concretagens destinadas aos diversos tipos de ensaios, os quais são realizados com controle de deformação e elementos instrumentados. Realizam-se ainda, ensaios com corpos-de-prova cilíndricos para correlacionar a resistência à compressão e a tração (por compressão diametral) do concreto.

Tabela 3.2 - Quantidade de elementos moldados durante a concretagem destinada aos ensaios de blocos e prismas para cada grupo de resistência.

\begin{tabular}{ccccccc}
\hline & \multicolumn{5}{c}{ Corpos-de-prova } \\
Atividade & Blocos & \multicolumn{5}{c}{ Cilíndricos } \\
& & $5 \times 10$ & $10 \times 20$ & $15 \times 30$ & Cubos & Prismáticos \\
\hline PB & 5 & 9 & 9 & 9 & 3 & 5 \\
PPC & 10 & - & 5 & 5 & - & - \\
CC & - & - & 64 & 10 & - & - \\
\hline PB - Produção de blocos & & & & & \\
PPC - Produção de prismas colados \\
CC - Caracterização do concreto.
\end{tabular}

A concretagem dos corpos-de-prova, ilustrada na Figura 3.13, é semelhante à executada com os blocos, preenchidos e adensados sobre mesa vibratória. 


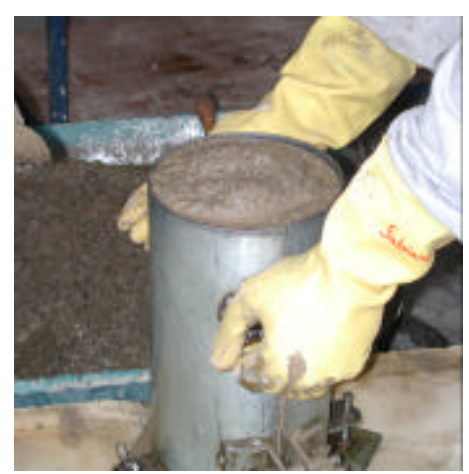

(a)

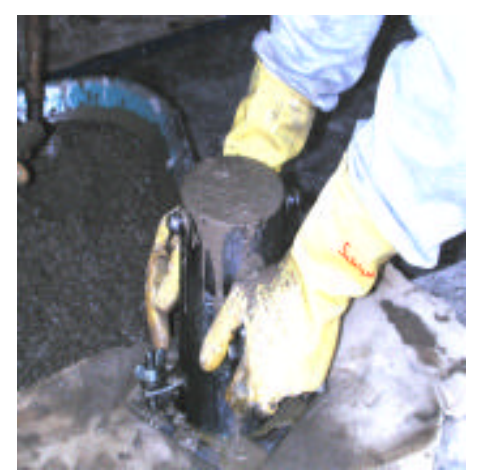

(b)

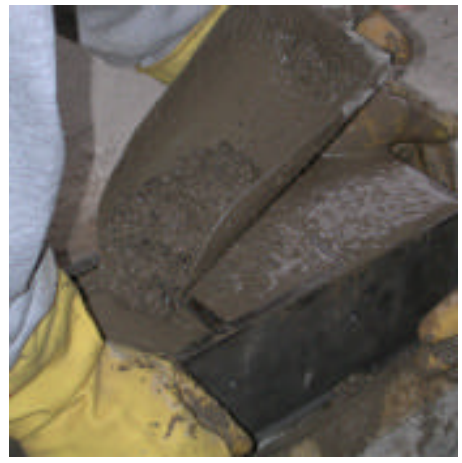

(c)

Figura 3.13 - Adensamento dos corpos-de-prova cilíndricos 15 x $30 \mathrm{~cm}$ (a), 10 x $20 \mathrm{~cm}$ (b) e cúbicos(c).

A Figura 3.14 apresenta os elementos após a concretagem, que receberão acabamento final no topo, sendo no dia seguinte levados à câmara úmida.

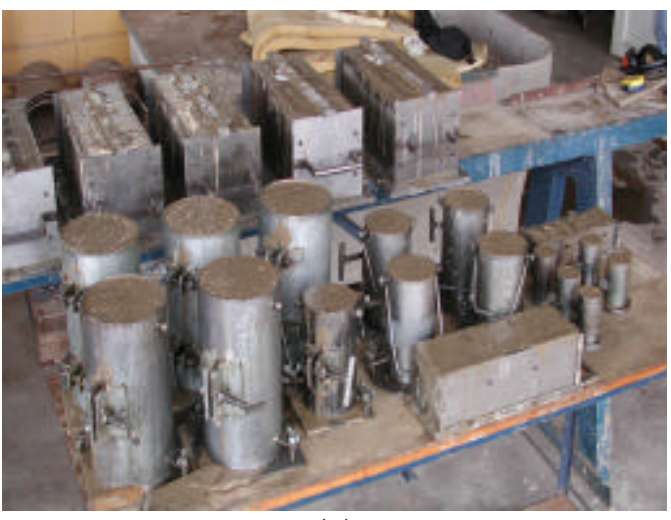

(a)

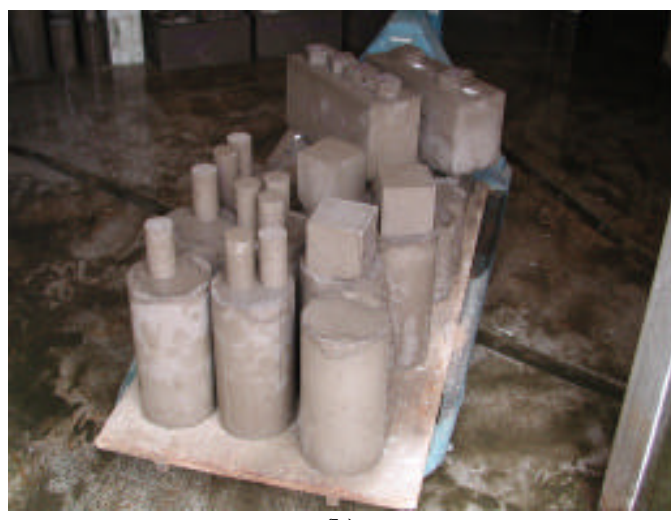

(b)

Figura 3.14 - Elementos após a concretagem (a) e sendo colocados na câmara úmida (b).

Os corpos-de-prova cilíndricos são capeados com enxofre (Figura 3.4), entretanto, os cúbicos e prismáticos não recebem nenhum material de acabamento, pois estes possuem duas faces planas e paralelas - devido à sua configuração geométrica que são as superfícies de carregamento.

\subsubsection{Detalhamento dos ensaios}

Na máquina universal de ensaios da marca Instron, realizam-se ensaios com 2 corpos-de-prova de cada geometria, para um determinado grupo de ensaios, a fim de obter-se o módulo de elasticidade do material. Ensaiam-se à compressão os demais corpos-de-prova da série (Tabela 3.2) e todos os referentes à caracterização do concreto na máquina de ensaios da marca ELE.

Os ensaios com corpos-de-prova cilíndricos de $10 \times 20 \mathrm{~cm}$, que possui altura próxima a dos blocos de concreto, realizam-se com taxa de deslocamento de 0,005 
$\mathrm{mm} / \mathrm{s}$. Para os ensaios com os demais corpos-de-prova a taxa de deslocamento é alterada com o objetivo de manter constante as taxas de deformação. As taxas de deslocamento nos ensaios de corpos-de-prova cilíndricos $5 \times 10 \mathrm{~cm}$ e cúbico, $15 \times 30$ cm e prismáticos são respectivamente de $0,003 \mathrm{~mm} / \mathrm{s}, 0,007 \mathrm{~mm} / \mathrm{s}$ e $0,002 \mathrm{~mm} / \mathrm{s}$, equivalente a uma deformação de $25 \mu \varepsilon /$ s. Nos demais ensaios, sem controle de deslocamento, de resistência à compressão, a velocidade do ensaios é de $0,5 \mathrm{kN} / \mathrm{s}, 2,4$ $\mathrm{kN} / \mathrm{s}, 5,3 \mathrm{kN} / \mathrm{s}$ e $3 \mathrm{kN} / \mathrm{s}$ para os corpos-de-prova cilíndrico 5 x $10 \mathrm{~cm}$ e prismático, cilíndrico 10 x $20 \mathrm{~cm}$, cilíndrico 15 x $30 \mathrm{~cm}$ e cúbico, respectivamente. Os corpos-deprova estão em contato direto com o prato articulado da prensa, em sua face superior, e com a base de aço, em sua face inferior.

Realizam-se também ensaios para determinação da resistência à tração por compressão diametral de corpos-de-prova cilíndricos 10 x $20 \mathrm{~cm}$. Colocam-se entre os pratos da máquina e os corpos-de-prova duas tiras de alumínio sobre toda a geratriz do CP. A força é aplicada pelo prato da máquina sobre uma barra de aço que está disposta sobre a tira superior, a uma velocidade de $0,94 \mathrm{kN} / \mathrm{s}$.

Para o cálculo da resistência à tração indireta a NBR 7222 (1994) apresenta a Equação (3.2), semelhante à Equação (3.1):

$$
\mathrm{f}_{\mathrm{ct}, \mathrm{sp}}=\frac{20 \mathrm{~F}}{\mathrm{p} \mathrm{d} \mathrm{l}}
$$

$\mathrm{f}_{\mathrm{ct}, \mathrm{sp}}$ é a resistência à tração por compressão diametral (MPa);

F é a força máxima obtida no ensaio $(\mathrm{kN})$;

d é o diâmetro do corpo-de-prova $(\mathrm{cm})$;

l é altura do corpo-de-prova $(\mathrm{cm})$.

\subsubsection{Instrumentação}

Como base de medida, dois extensômetros removíveis são dispostos na altura média e "ao longo de geratrizes igualmente espaçadas no perímetro da seção transversal do corpo-de-prova", seguindo a recomendação da NBR 8522 (1984). Utilizam-se as bases de medida correspondentes à metade do valor da altura de cada elemento, modificando-se a altura do instrumento de medição ${ }^{4}$.

\footnotetext{
4 As bases de medida dos extensômetros removíveis são: $2,5 \mathrm{~cm}, 5 \mathrm{~cm}, 10 \mathrm{~cm}$ e $15 \mathrm{~cm}$. Por isso, nos ensaios com corpos-de-prova prismáticos $(3 \times 3 \times 6 \mathrm{~cm})$ utiliza -se a base de medida de $2,5 \mathrm{~cm}$.
} 
Nos corpos-de-prova cilíndricos de 10 x $20 \mathrm{~cm}$, do grupo 10, foram colocados quatro extensômetros elétricos para determinar o coeficiente de Poisson, dois em cada face oposta, um no sentido longitudinal e outro no sentido transversal (Figura 3.15a). A Figura 3.15 b apresenta o ensaio de um corpo-de-prova cúbico, instrumentado apenas com extensômetros removíveis.

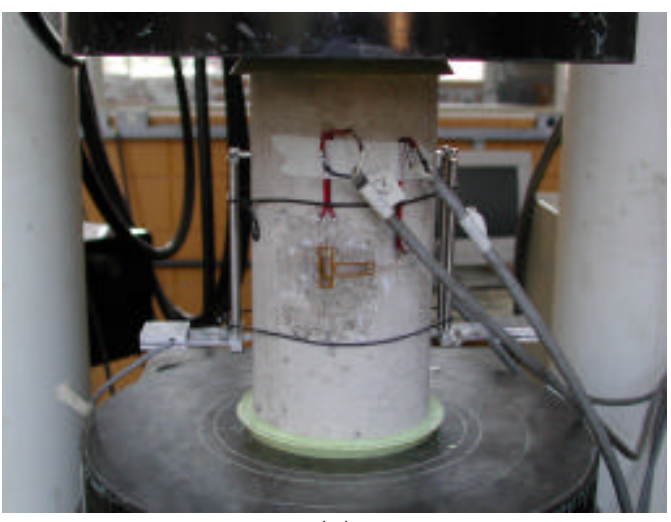

(a)

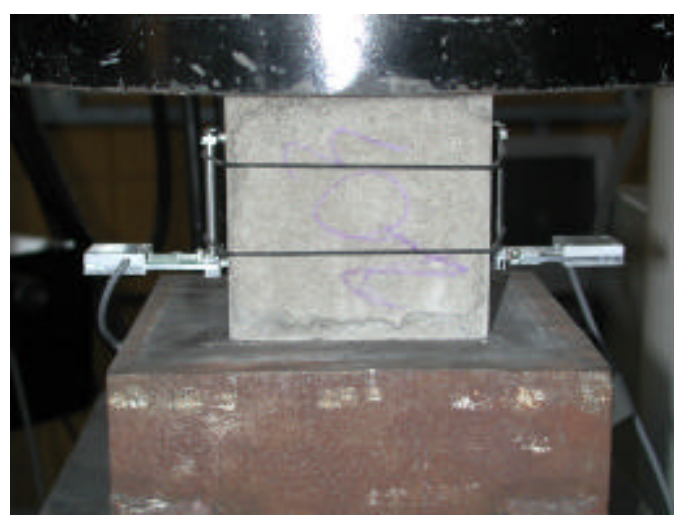

(b)

Figura 3.15 - Detalhe da instrumentação do corpo-de-prova cilíndrico 10 x $20 \mathrm{~cm}$ com utilização de extensômetros elétricos e extensômetros removíveis (a). Instrumentação, com extensômetros removíveis, utilizada nos ensaios em corpos-de-prova cúbicos.

Nos ensaios de compressão diametral obteve-se apenas a força máxima, não sendo utilizado nenhuma instrumentação no CPs. A Figura 3.16 apresenta este ensaio.

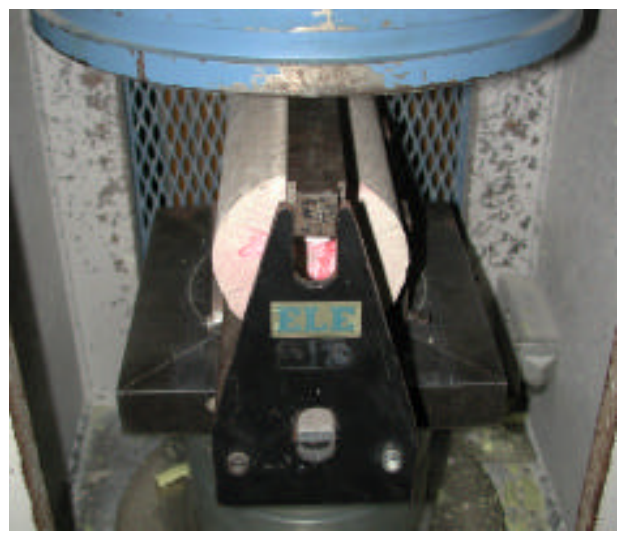

Figura 3.16 - Ensaio de resistência à tração por compressão diametral.

\subsubsection{Comportamento dos corpos-de-prova}

Os corpos-de-prova apresentam fissuração visível apenas quando a força atinge valores próximos à força máxima. Depois de atingida essa força, notam-se grandes deformações e a intensificação da fissuração. Observam-se fissuras diagonais, distribuídas indefinidamente, que provocam o destacamento da superfície do concreto. 
A ruína é caracterizada pelo cisalhamento diagonal, conforme destacam a Figura 3.17 e a Figura 3.18.

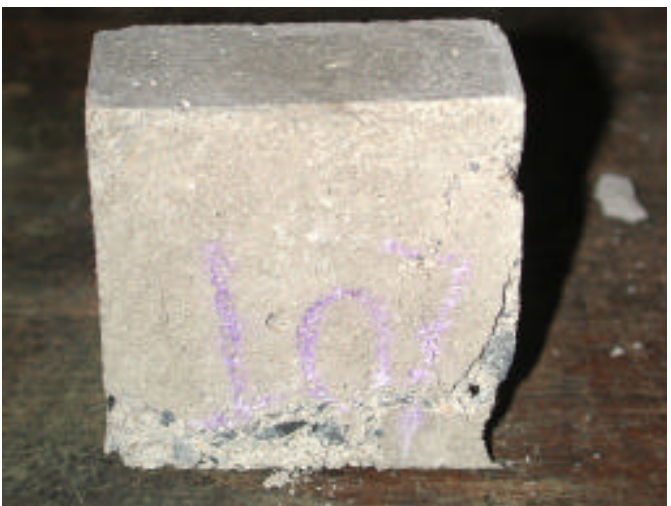

(a)

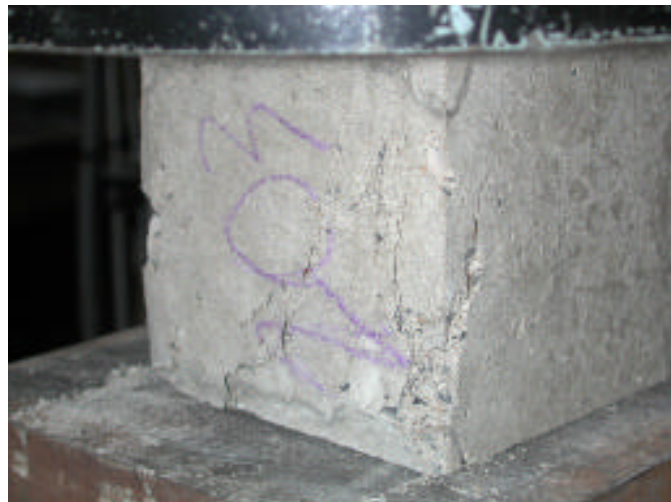

(b)

Figura 3.17 - Caracterização da ruína do corpo-de-prova prismático (a) e cúbico (b).

A ruína dos corpos-de-prova cilíndricos também ocorre sob forma de cisalhamento diagonal, particularizada devido à sua geometria pelo cisalhamento tronco-cônico.

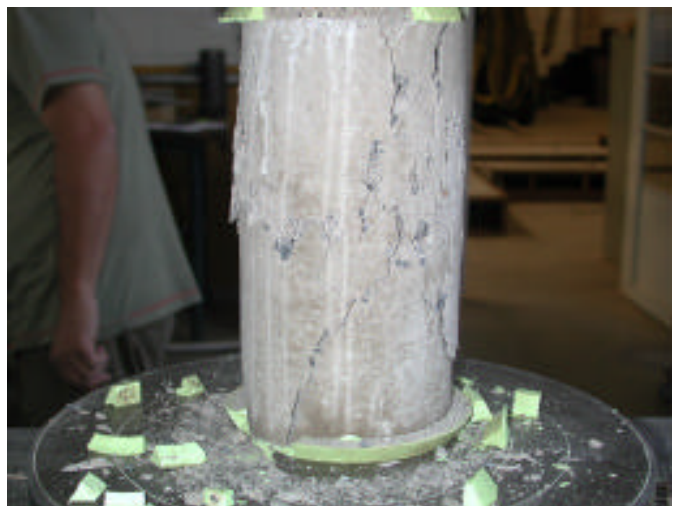

(a)

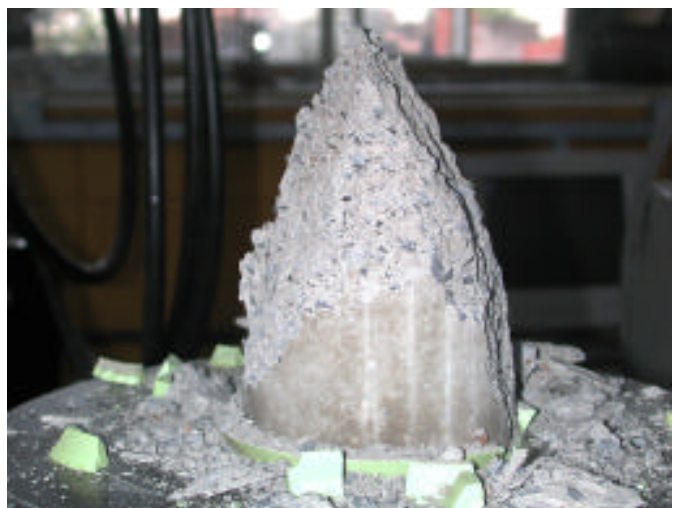

(b)

Figura 3.18 - Ruína dos corpos-de-prova cilíndricos após intensa fissuração (a) e o colapso total do elemento caracterizando a forma "cônica" do cisalhamento (b).

Nos ensaios à tração ocorre fissuração vertical no plano médio que corta o CP. Essas fissuras tendem a separar o $\mathrm{CP}$ em duas partes distintas como pode ser observado na Figura 3.19. 


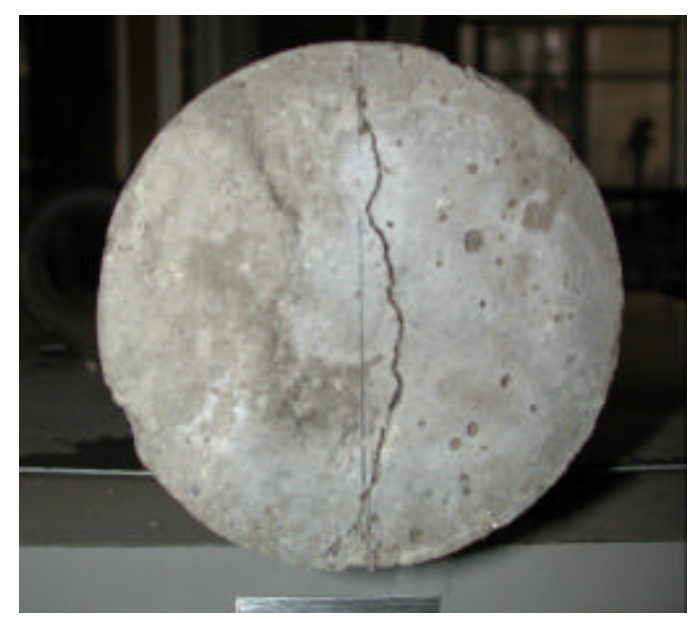

(a)

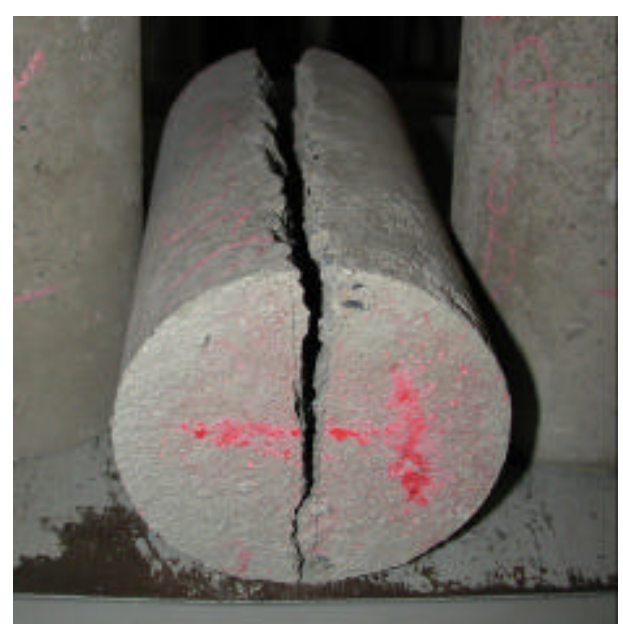

(b)

Figura 3.19 - Fissura vertical na base (a) e ao longo da altura do corpo-de-prova cilíndrico, separando-o em duas partes (b).

\subsection{Blocos associados sem junta de argamassa}

Os prismas ${ }^{5}$ constituídos por dois e três blocos, sem junta de argamassa, são obtidos pela sobreposição de blocos, interligados por uma fina camada de Compound Adesivo (adesivo estrutural à base de epóxi) que, segundo a Vedacit (2003), apresenta resistência inicial em 24 horas e resistência máxima aos 7 dias.

A aplicação dessa camada tem como objetivo propiciar a continuidade perfeita do conjunto, permitindo a analise do efeito da variação da altura de um bloco (representado por um prisma colado) quando submetido à compressão. Optou-se pela aplicação do adesivo à base de epóxi, já que a justaposição sem nenhum outro material poderia ocasionar concentração de tensões e ruptura prematura dos elementos. Por ser aplicado em uma fina camada, supõe-se que o material não interfira nos resultados de deformação dos prismas.

Após a retirada dos EPS's e a execução do capeamento dos blocos, constroemse os prismas sem junta de argamassa, aplicando-se uma camada de adesivo sobre toda a superfície de carregamento dos blocos. Tal procedimento ocorre com antecedência mínima de 24 horas à realização dos ensaios.

\footnotetext{
5 O meio técnico comumente define os prismas de alvenaria como um corpo-de-prova, constituído por unidades, com largura e comprimento iguais aos de uma unidade de alvenaria e com altura igual ou superior à altura de duas unidades, intercaladas por juntas de argamassa. Neste trabalho, o referido termo é também definido como um elemento oriundo da associação de dois ou três blocos sem a presença da junta de argamassa.
} 
De acordo com ensaios realizados por Bauer $(2002)^{6}$, a resistência à compressão média em corpos-de-prova cilíndricos de $25 \times 25 \mathrm{~mm}$, moldados com o adesivo e decorridas 24 horas da preparação do produto, foi de 35,5 MPa. A resistência à compressão é de 53,5 MPa aos 2 dias, 60,9 $\mathrm{MPa}$ aos 3 dias e 67,9 aos 7 dias. Já nos ensaios de arrancamento de barra de aço (de $16 \mathrm{~mm}$ de diâmetro e profundidade de 15 cm) fixada com o adesivo em blocos de concreto, Bauer (1995) ${ }^{7}$ encontrou tensão média de 8,3 MPa. Esses ensaios indicam os altos valores de resistência alcançados em poucos dias, que supera inclusive a resistência à compressão do concreto do grupo 30, o de maior resistência, deduzindo-se que nos ensaios com prismas a ruína não ocorra por esmagamento da camada do adesivo.

A Figura 3.20 ilustra as etapas de construção dos prismas colados de dois blocos.

A aplicação do adesivo à base de epóxi se dá nas superfícies de carregamento do bloco que possui maior regularidade. A superfície que fica em contato com a base da fôrma metálica é lisa e plana, portanto a escolhida para ser a interface entre os blocos, resultando em um perfeito acoplamento. As superfícies de carregamento que recebem acabamento manual após a concretagem são regularizadas com o capeamento de enxofre.

No caso dos prismas constituídos por três blocos, procede-se da mesma maneira na escolha da superfície de carregamento a ser capeada com enxofre, entretanto, o bloco central possui as duas superfícies de carregamento em contato com o adesivo, impossibilitando duas interfaces com as superfícies bem acabadas. Nos prismas do grupo 10 observou-se que, nessa interface, devido à fina camada de adesivo aplicada e a má regularização de uma das superfícies, ocorreu o contato entre as superfícies apenas em determinados pontos. Nos outros prismas, aumentou-se a quantidade de adesivo aplicado na superfície, obtendo-se uma camada mais espessa, com as irregularidades sendo preenchidas por esse excesso.

${ }^{6}$ CENTRO TECNOLÓGICO DE CONTROLE DA QUALIDADE L.A. FALCÃo BAUER (2002). Relatório de ensaio E/70.048/02. São Paulo.

7 CENTRO TECNOLÓGICO DE CONTROLE DA QUALIDADE L.A. FALCÃO BAUER (1995). Relatório de ensaio E/43.998/95. São Paulo. 


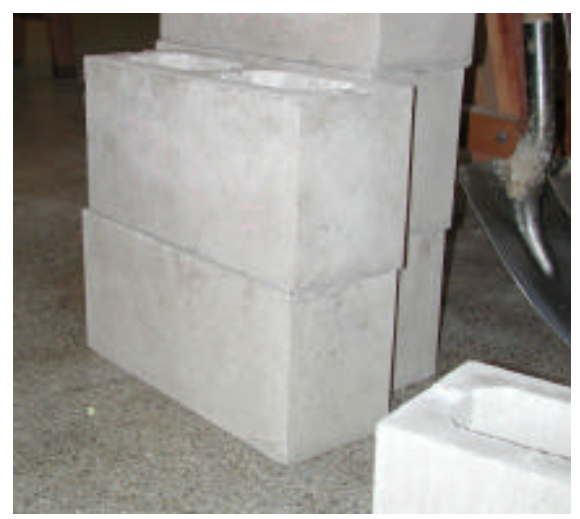

(a)

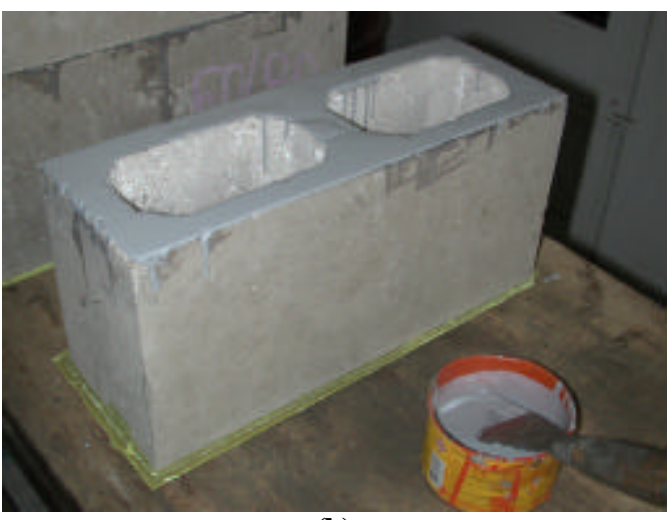

(b)

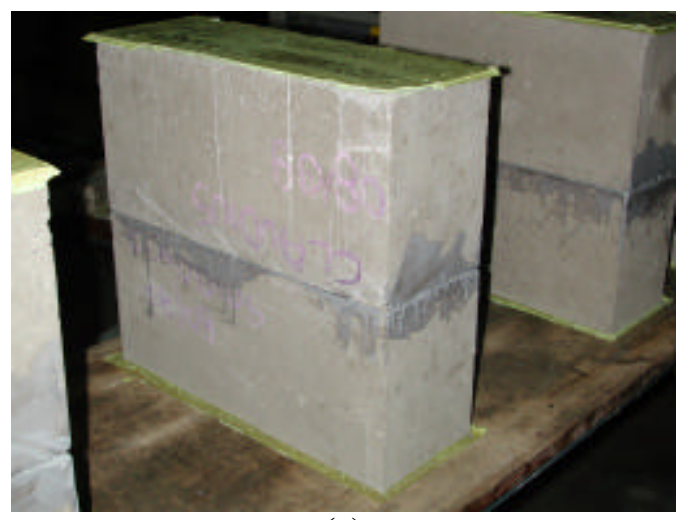

(c)

Figura 3.20 - Blocos separados para confecção dos prismas (a). Bloco inferior capeado com a camada do adesivo aplicada (b) e bloco superposto formando o prisma (c).

\subsubsection{Instrumentação}

A instrumentação dos prismas é, em parte, análoga à executada nos ensaios de blocos isolados. Como dito, o objetivo dos ensaios com esse tipo de elemento é analisar o comportamento de um bloco com altura igual a duas ou três vezes a altura de um bloco isolado, o que significa elementos com altura de $38 \mathrm{~cm}$ ou $57 \mathrm{~cm}$.

Nos ensaios de prismas constituídos por dois blocos colados, a instrumentação com os extensômetros removíveis (Figura 3.21 e Figura 3.22) está disposta na região central do prisma, inclusive com a mesma base de medida utilizada nos ensaios com blocos isolados $(10 \mathrm{~cm})$. Analisam-se os deslocamentos na região central do prisma (idealizada como sendo a de um bloco com $38 \mathrm{~cm}$ de altura) correlaciona ndo-os os com os deslocamentos obtidos nos ensaios com blocos. Utilizam-se três relógios comparadores na parede longitudinal oposta, com base de medida de $29 \mathrm{~cm}$ que abrange praticamente a altura total do prisma (Figura 3.22b). 


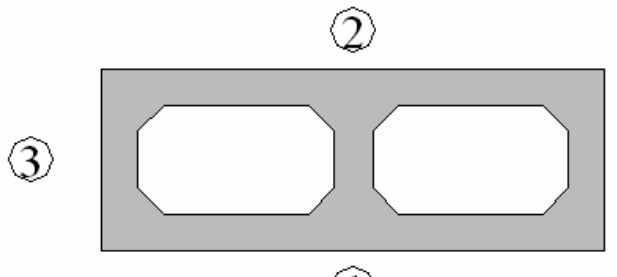

(1)

(1)
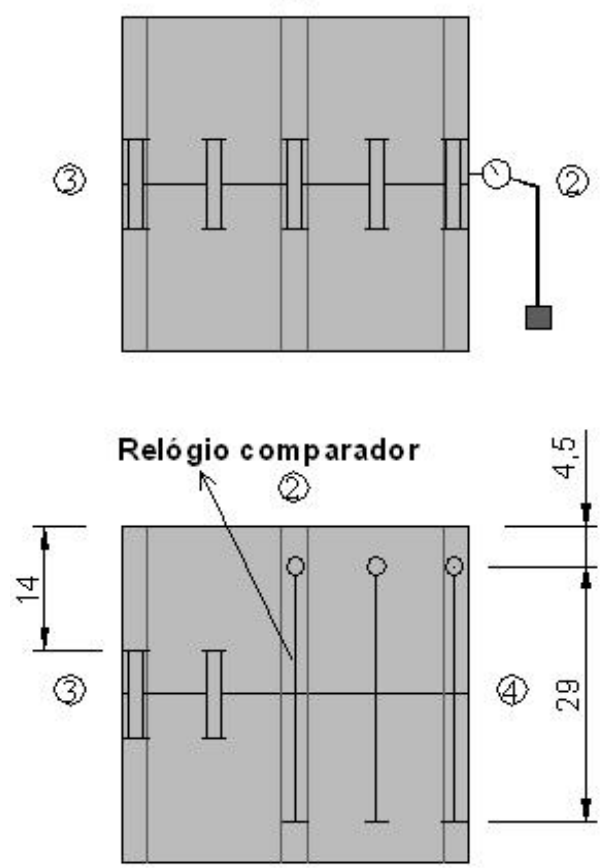

(b)

\section{Bases de medida}

Extensômetro removível: $100 \mathrm{~mm}$

Transdutor de deslocamento: $90 \mathrm{~mm}$

Relógio comparador: $290 \mathrm{~mm}$

(a)
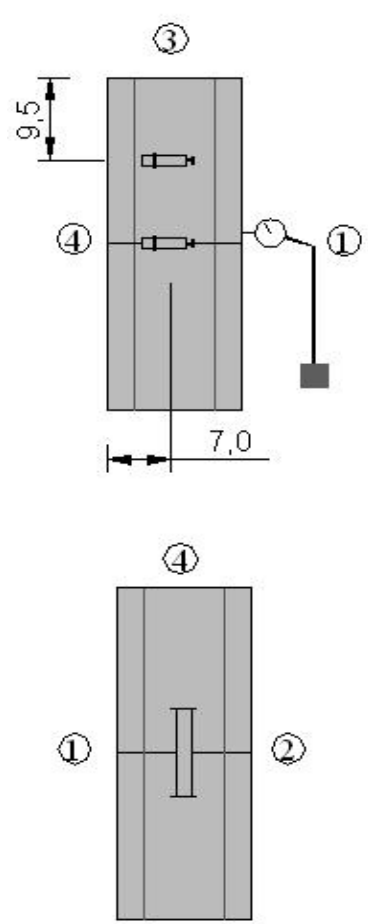

(c)

Figura 3.21 - Vista superior do prisma de dois blocos e bases de medida dos instrumentos (a). Detalhe da instrumentação utilizada nas paredes longitudinais (b) e septos trans versais (c) nos ensaios com prismas colados de dois blocos.

Dispõem-se ainda de dois relógios comparadores na região próxima à interface entre os blocos, um no septo transversal e outro na parede longitudinal.

Dois transdutores de deslocamento, situados m septo transversal do prisma, localizados próximos à interface entre os blocos e na altura média do bloco superior, medem os deslocamentos transversais dos blocos (Figura 3.22a). 


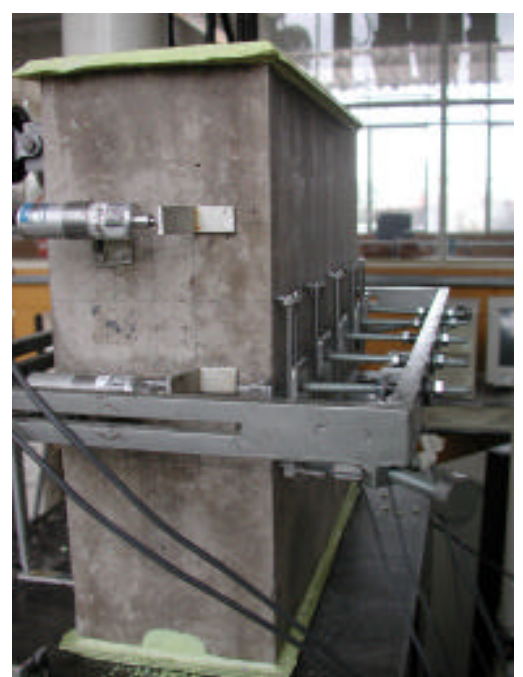

(a)

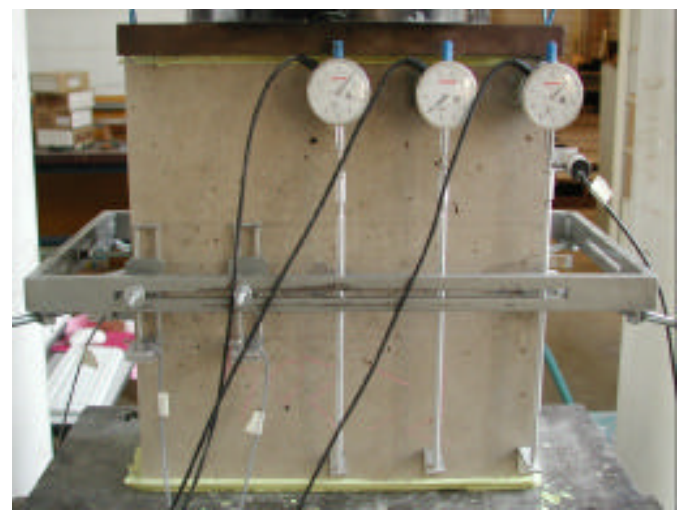

(b)

Figura 3.22 - Instrumentação utilizada nos prismas constituídos por dois blocos. Detalhe da parede longitudinal e septo transversal com extensômetros removíveis e transdutores de deslocamento (a) e parede longitudinal oposta instrumentada com extensômetros removíveis e relógios comparadores $(b)$.

A Figura 3.23 ilustra a instrumentação nos prismas de três blocos, análoga à dos prismas constituídos por dois blocos e à utilizada nos blocos isolados.

Os extensômetros removíveis estão localizados no bloco central (Figura 3.24a), com posicionamento idêntico ao utilizado nos ensaios com blocos isolados, dispondo-se ainda de três relógios comparadores (com base de medida de $48 \mathrm{~cm}$ ) na parede longitudinal oposta (Figura 3.24b). 


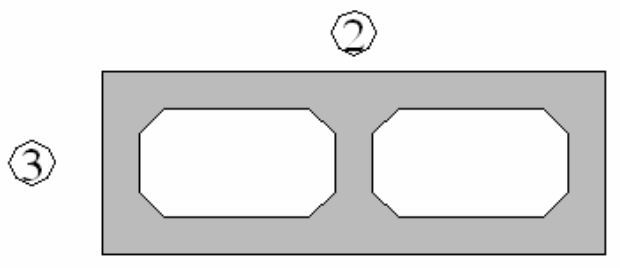

(1)
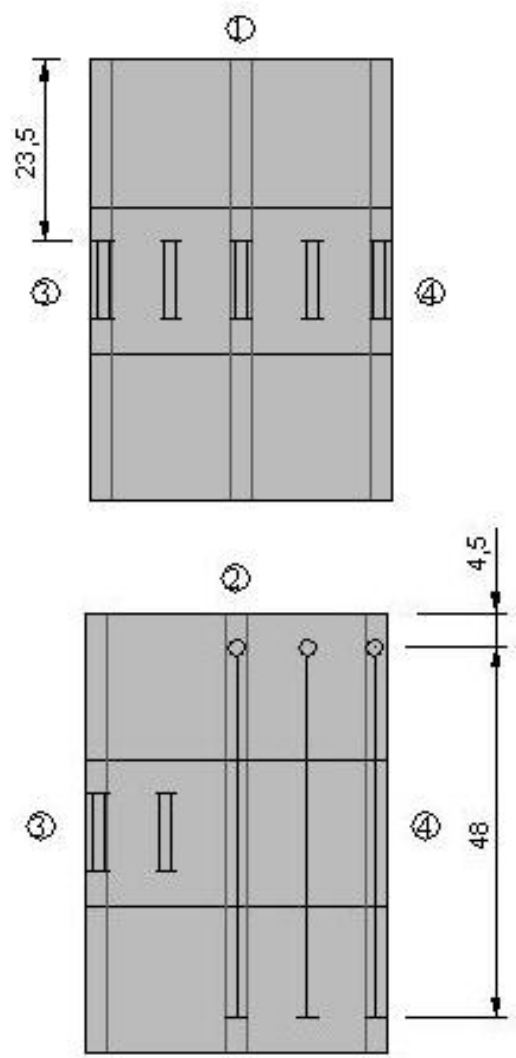

(b)

\section{Bases de medida}

Extensômetro removível: $100 \mathrm{~mm}$

(4)

Transdutor de deslocamento: $90 \mathrm{~mm}$

Relógio compar ador: $480 \mathrm{~mm}$

(a)

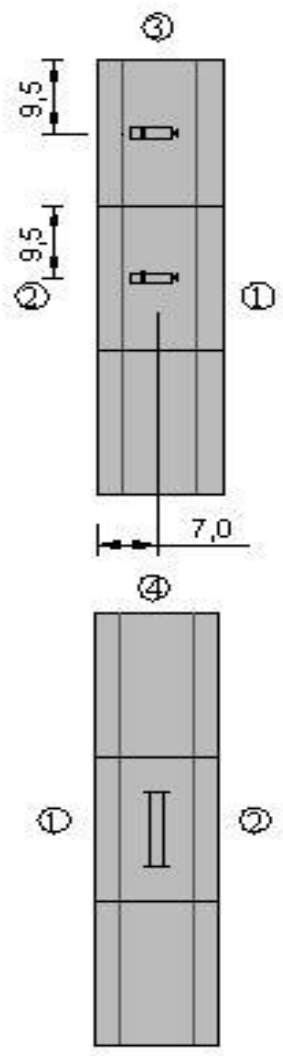

(c)

Figura 3.23 - Vista superior do prisma de três blocos e bases de medida dos instrumentos (a).

Detalhe da instrumentação utilizada nas paredes longitudinais (b) e septos transversais (c) nos ensaios de prismas colados de três blocos.

Obtêm-se os deslocamentos transversais por meio de extensômetros removíveis, localizados no septo transversal do prisma, na altura média do bloco central e na altura média do bloco superior, como ilustrado na Figura 3.24b. 


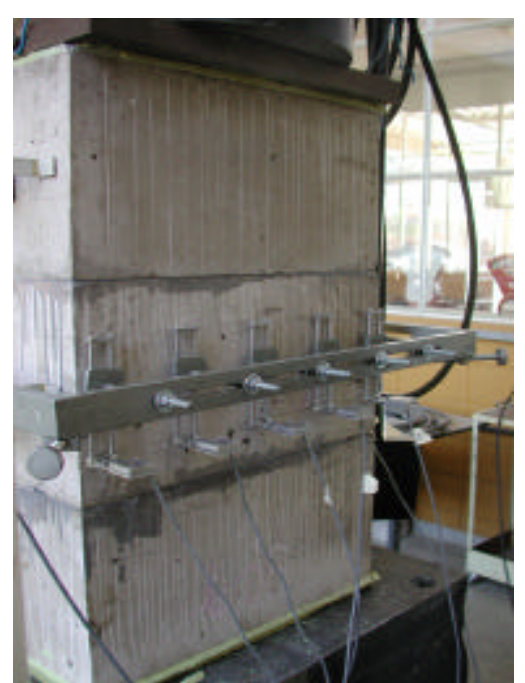

(a)

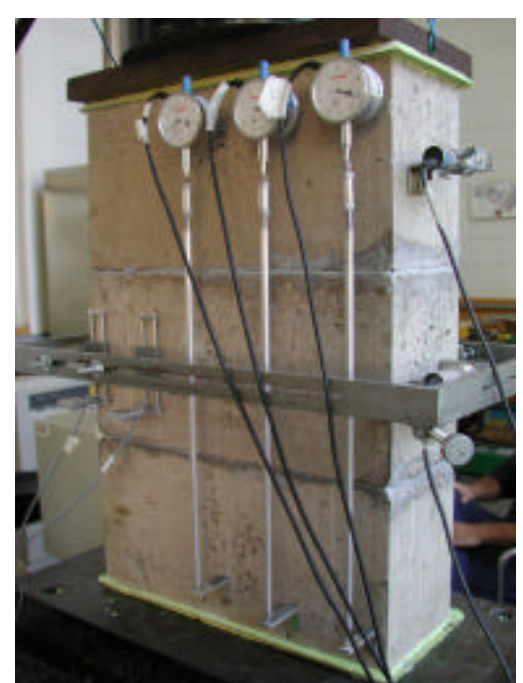

(b)

Figura 3.24 - Instrumentação dos prismas constituídos por três blocos. Detalhe dos extensômetros removíveis no bloco central (a). Extensômetros removíveis e relógios comparadores na parede longitudinal oposta do prisma e transdutores de deslocamento no septo transversal (b).

\subsubsection{Comportamento dos elementos}

Todos os prismas constituídos por dois blocos apresentaram comportamento semelhante. As primeiras fissuras, que surgem entre $50 \%$ e $60 \%$ da força máxima, são verticais e estão localizadas na parede longitudinal do prisma, na região da parede que compreende o vazio do bloco e comumente próxima ao septo transversal central. O comprimento inicial da fissura, à primeira vista, não é maior que $5 \mathrm{~cm}$ e está situada próxima à interface entre os blocos.

Com o prosseguimento do ensaio, a fissura tende a aumentar o seu comprimento e a sua abertura, ao mesmo tempo em que novas fissuras aparecem, sempre na mesma região (entre os septos transversais externos e o central), aleatoriamente nas duas faces do bloco. Elas tendem a se alongar, inclusive atravessando a interface entre os blocos, com suave inclinação. Essas fissuras estão apresentadas na Figura 3.25a.

Quando se atinge aproximadamente $95 \%$ da força máxima, o prisma apresenta extensas fissuras, algumas com aberturas de 2 a $3 \mathrm{~mm}$. Nesse nível, algumas vezes identificam-se fissuras nos septos transversais, como pode ser observado na Figura 3.25 e na Figura 3.26. Algumas das fissuras das paredes longitudinais aumentam a inclinação em direção aos septos transversais; outras tendem a se encontrar, ocasionando destacamento do concreto. Na região próxima ao topo ou à base do prisma, na iminência 
da força máxima, ocorre intenso destacamento do concreto e, no pós-pico, ruína localizada por cisalhamento diagonal.

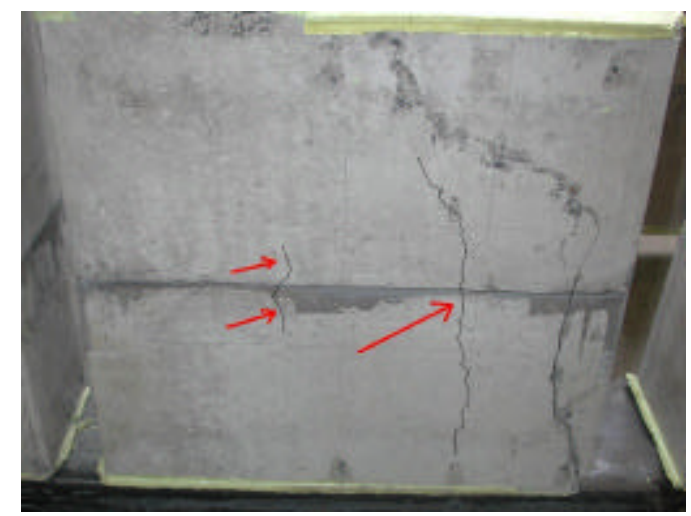

(a)

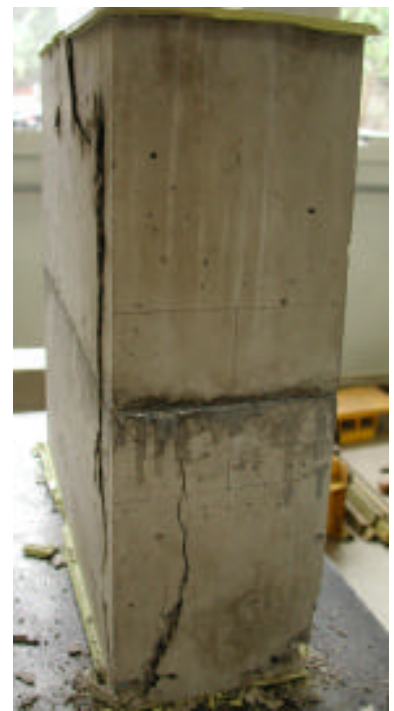

(b)

Figura 3.25 - Ruína dos prismas: fissuras na parede longitudinal (a) e fissura no septo transversal com detalhe para o destacamento de parte da parede longitudinal (b).

A ruína do prisma ocorre por fissuração vertical, iniciada e intensificada nas paredes longitudinais e algumas vezes nos septos transversais. As fissuras tendem a separar a parede longitudinal (e/ou septo transversal) como ilustra a Figura 3.25b.

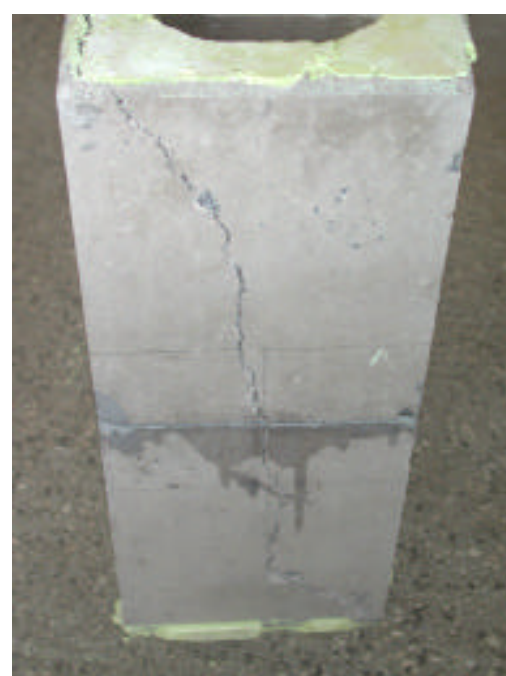

(a)

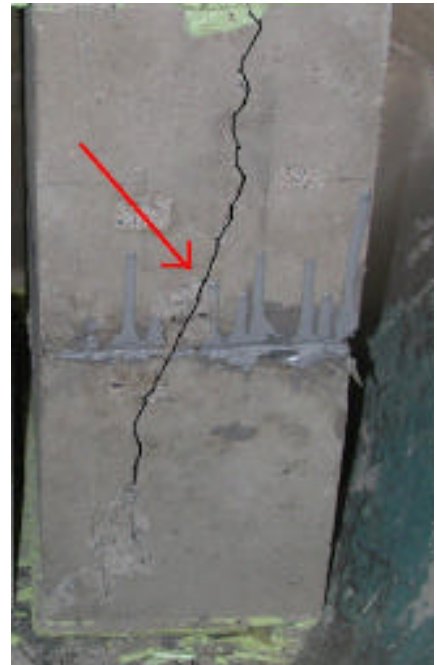

(b)

Figura 3.26 - Fissuras no septo transversal: atingindo a parede lateral (a) e inclinado-se em direção à extremidade (b).

O aparecimento e a distribuição de fissuras ocorreu de maneira análoga nos prismas constituídos por três blocos, inclusive para os elementos de diferentes níveis de resistência. Identificou-se a primeira fissura no intervalo entre $30 \%$ e $50 \%$ da força máxima vertical e na parede longitudinal do prisma, próxima à interface entre o bloco 
superior (ou inferior) e o bloco central e ao septo transversal central. A fissura expandese com o aumento da força, ao mesmo tempo em que surgem novas fissuras. A fissuração nos prismas constituídos por três blocos é apresentada na Figura 3.27.

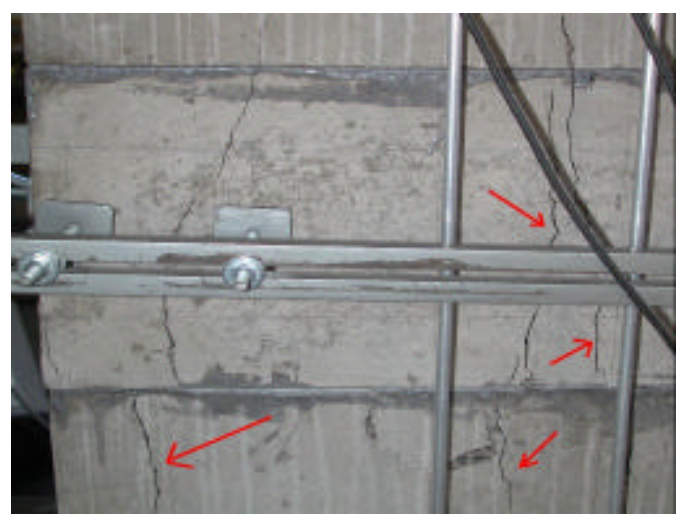

(a)

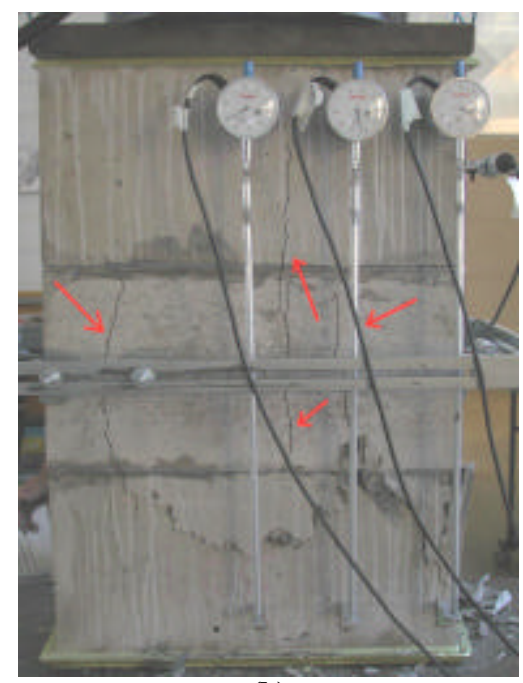

(b)

Figura 3.27 - Fissuras ao longo da parede longitudinal do prisma constituído por três blocos, atravessando a interface entre eles (a) e (b) e cisalhamento diagonal no bloco inferior (b).

Quando o ensaio aproxima-se da força máxima (em torno de 95\%), o prisma apresenta-se com as fissuras bem visíveis e distribuídas por todas as suas faces, com tendência de prolongamento com leve inclinação em direção aos septos transversais nas regiões de topo e de base. Surgem, em alguns prismas, fissuras no septo transversal central. $\mathrm{O}$ encontro de algumas fissuras promove o destacamento do concreto. Observase também, como ilustrado na Figura 3.27b, o cisalhamento diagonal nos blocos de extremidade, na região próxima às extremidades.

A ruína dos prismas constituídos por três blocos ocorre devido à intensa fissuração nas paredes longitudinais, sendo observada, muitas vezes, fissuração nos septos transversais, ilustrado na Figura 3.28. Após atingir a força máxima, evidencia-se nos blocos extremos a fissuração diagonal, às vezes induzida pelo encontro de fissuras.

A fissuração dos septos transversais ocorre quando se atinge forças próximas à máxima e devido à perda de rigidez das paredes longitudinais, que não são capazes de absorver as deformações devido ao alto estágio de fissuração, transferindo-as para outra região da estrutura. 


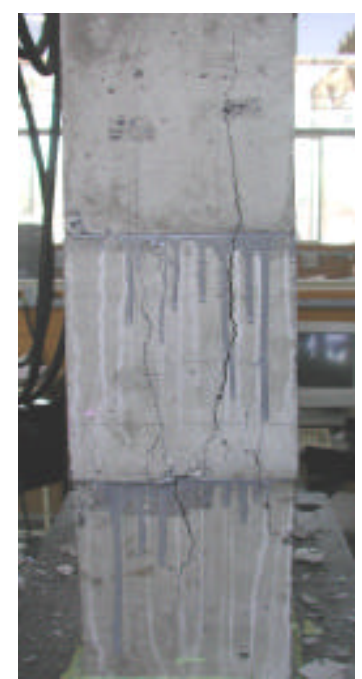

(a)

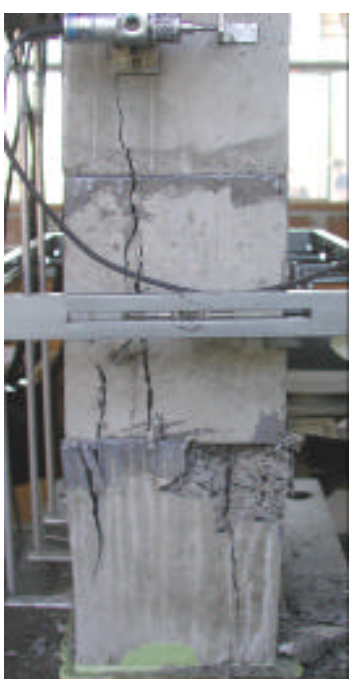

(b)

Figura 3.28 - Fissuras no septo transversal dos prismas constituídos por três blocos (a) e (b), apresentando a tendência de separação da parede longitudinal do bloco inferior (b).

Em função da imperfeição ocorrida no assentamento dos blocos do grupo 10, os prismas com altura de $57 \mathrm{~cm}$ apresentaram fissuras a $5 \%$ da força máxima devido à flexão que ocorre na região em que não há contato entre as superfícies de dois blocos.

Nestes ensaios, torna-se evidente a mudança do comportamento dos prismas em relação aos blocos, justificada principalmente pela diferença na altura dos elementos. Dessa forma, a região central passa a sofrer menor efeito do confinamento exercido pelas placas de ensaio alterando a forma de ruína. Nos ensaios realizados por Page e Kleeman (1991) não foi observada nenhuma mudança significativa no modo de ruína dos blocos ensaiados com placa-escova e de acordo como método padrão, entretanto, nestes ensaios observou-se que a fissuração ocorreu em toda a altura da unidade. Nos ensaios com placa-escova citados por Drysdale et al. (1994), nota-se claramente as fissuras verticais nas paredes dos blocos, caracterizando o modo de ruína nesses ensaios. A mudança não significativa de comportamento nos ensaios realizados por Page e Kleeman (1991) pode ser atribuída ao capeamento, que foi colocado apenas nas paredes longitudinais, permitindo o surgimento de fissuras verticais nos septos transversais, conforme indicam os próprios autores. 


\section{ANÁLISE DOS RESULTADOS EXPERIMENTAIS}

Discutem-se os resultados obtidos nos ensaios com corpos-de-prova, blocos e prismas de blocos colados, constituídos por 2 e 3 blocos, apresentando-se as correlações entre suas propriedades mecânicas.

Realizam-se as análises de cada grupo de resistência individualmente de posse da resistência média à compressão, módulo de elasticidade e do valor das deformações dos elementos ensaiados.

A resistência à compressão corresponde à média aritmética dos valores máximos de tensão obtidos em cada ensaio de um determinado grupo de resistência, sempre em relação à área líquida dos elementos.

Obtêm-se as curvas médias de tensão-deformação, o módulo de elasticidade e o valor da deformação última dos elementos. Dentre as curvas obtidas nos diversos pontos, uma é escolhida para representar genericamente o comportamento destes.

Calcula-se o valor do módulo de elasticidade seguindo as prescrições da ASTM C 469 (1987), que considera uma deformação específica inicial na curva de ensaio, de $50 \times 10^{-6}$, admitindo a tensão para o cálculo dos diferentes módulos a $40 \%$ da resistência à compressão do concreto. $\mathrm{O}$ valor do módulo de elasticidade é a inclinação da reta secante à curva tensão-deformação que une esses pontos.

Os valores obtidos das deformações referem-se a um determinado nível da tensão média.

Correlacionam-se ainda, os valores de resistência obtidos nos ensaios com os elementos. 


\subsection{Caracterização da resistência do concreto}

Realizaram-se ensaios de resis tência à compressão e à tração com quatro séries de corpos-de-prova, objetivando estabelecer correlações entre essas propriedades mecânicas. Cada série é composta por determinados grupos de resistência, ensaiados com diferentes idades. Na Tabela 4.1 são apresentadas a resistência média à compressão do concreto $\left(\mathrm{f}_{\mathrm{cm}}\right)$ e a resistência média do concreto à tração indireta $\left(\mathrm{f}_{\mathrm{ct}, \mathrm{sp}}\right)$, para cada grupo.

\begin{tabular}{|c|c|c|c|c|c|}
\hline Série & $\begin{array}{l}\text { Idade } \\
\text { (dias) }\end{array}$ & Grupo & $\begin{array}{c}\mathrm{f}_{\mathrm{cm}} \\
(\mathrm{MPa})\end{array}$ & $\begin{array}{c}\mathrm{f}_{\mathrm{ct}, \mathrm{sp}} \\
(\mathrm{MPa})\end{array}$ & $\frac{\mathrm{f}_{\mathrm{ctsp}}}{\mathrm{f}_{\mathrm{cm}}}$ \\
\hline \multirow{3}{*}{ S1 } & \multirow{3}{*}{18} & 10 & 12,3 & 1,2 & 0,10 \\
\hline & & 20 & 16,8 & 1,8 & 0,11 \\
\hline & & 30 & 37,1 & 2,8 & 0,08 \\
\hline \multirow{3}{*}{ S2 } & \multirow{3}{*}{30} & 10 & 13,2 & 1,5 & 0,11 \\
\hline & & 20 & 18,1 & 1,8 & 0,10 \\
\hline & & 30 & 35,7 & 2,7 & 0,08 \\
\hline S3 & 66 & 30 & $30,9^{?}$ & 2,7 & 0,09 \\
\hline \multirow{3}{*}{ S4 } & \multirow{3}{*}{90} & 10 & $14,1^{?}$ & 1,9 & 0,14 \\
\hline & & 20 & $20,6^{?}$ & 2,2 & 0,11 \\
\hline & & 30 & $35,9^{?}$ & 3,1 & 0,09 \\
\hline
\end{tabular}

As relações entre as duas resistências dependem do nível de resistência do concreto. Ao se aumentar a resistência à compressão ocorre aumento da resistência à tração em uma razão decrescente. Essa redução corresponde à descrição de Neville (1997), entretanto, o autor cita que é de se esperar uma diminuição da relação com o aumento da idade do CPs, fato não ocorrido nestes ensaios. O autor cita ainda que os valores de resistência à tração obtidos por compressão diametral são muito próximos aos obtidos por tração direta, sendo em torno de 5\% a $12 \%$ maiores que estes.

A Figura 4.1 apresenta em gráfico os valores das resistências à compressão e à tração obtidas nos ensaios apresentados.

\footnotetext{
${ }^{1}$ Resistência à tração por compressão diametral (resistência à tração indireta).
} 


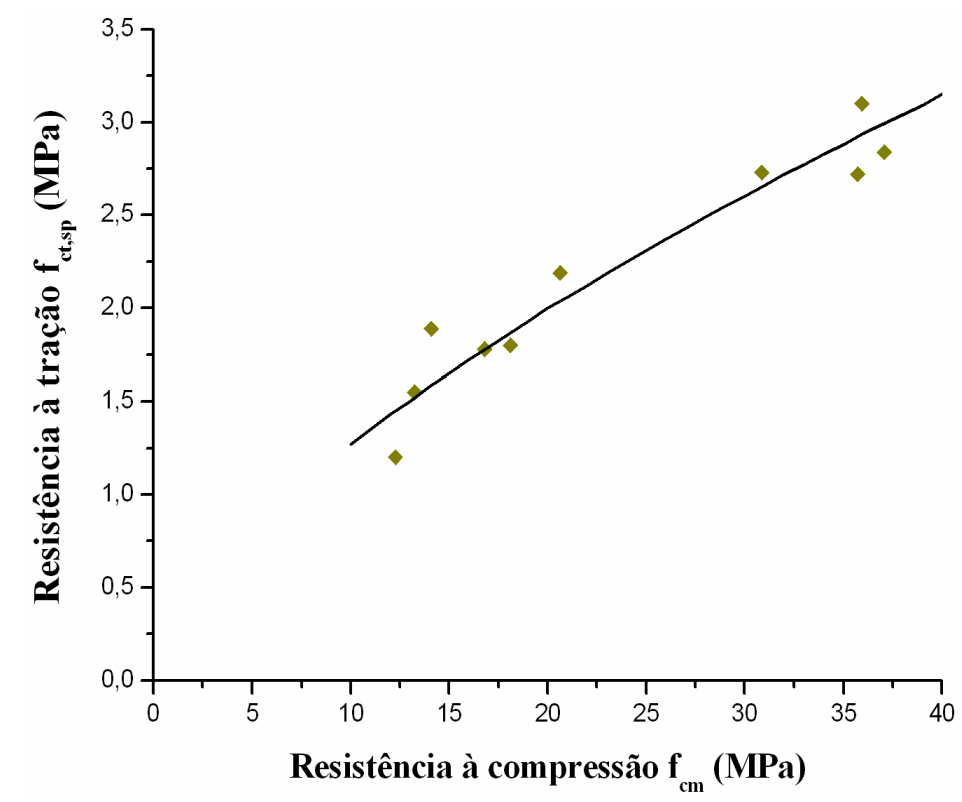

Figura 4.1 - Valores das resistências à tração e à compressão obtidos em corpos-de-prova cilíndricos e curva de tendência para o intervalo analisado.

A curva de tendência exponencial é ajustada para os referidos valores e descrita pela Equação (4.1):

$$
\mathrm{f}_{\mathrm{ctsp}}=0,28 \mathrm{f}_{\mathrm{cm}}^{0,66}
$$

Em relação às equações que correlacionam a resistência à tração e a resistência à compressão utilizadas por diversos pesquisadores e normas internacionais, Neville (1997), baseado na Equação (4.2), relata que algumas destas variam a constante multiplicadora e o expoente, este entre $1 / 2$ e $1 / 4$; sugere que os melhores resultados são encontrados quando utilizada a Equação (4.2):

$$
\mathrm{f}_{\mathrm{ctsp}}=0,3 \mathrm{f}_{\mathrm{cm}}^{2 / 3}
$$

A Equação (4.1), obtida nos ensaios experimentais com os níveis de concreto utilizados neste trabalho, conduz a valores próximos aos obtidos com a Equação (4.2), estando ainda suas constantes dentro dos limites utilizados. Dessa forma, adota-se a Equação (4.1) para cálculo das resistências do concreto à tração nos ensaios realizados. 


\subsection{Caracterização da resistência dos blocos de concreto}

Por meio de ensaios à compressão axial e à tração indireta (splitting test) obtiveram-se as resistências dos blocos de concreto à compressão e à tração. Os resultados são apresentados na Tabela 4.2.

Tabela 4.2 - Resistência à compressão e à tração dos blocos vazados de concreto.

\begin{tabular}{|c|c|c|c|c|}
\hline Grupo & $\begin{array}{c}\text { Idade } \\
\text { (dias) }\end{array}$ & $\begin{array}{c}\mathrm{f}_{\mathrm{bm}}{ }^{1} \\
(\mathrm{MPa})\end{array}$ & $\begin{array}{l}\mathrm{f}_{\mathrm{bt}, \mathrm{sp}}{ }^{2} \\
(\mathrm{MPa})\end{array}$ & $\frac{\mathrm{f}_{\mathrm{bt}, \mathrm{sp}}}{\mathrm{f}_{\mathrm{bm}}}$ \\
\hline 10 & 92 & 14,0 & 1,3 & 0,9 \\
\hline 20 & 92 & 17,7 & 1,9 & 0,11 \\
\hline 30 & 99 & 26,0 & 3,1 & 0,12 \\
\hline
\end{tabular}

${ }^{1}$ Resistência média à compressão do bloco de concreto, em relação à área líquida.

${ }^{2}$ Resistência do bloco de concreto à tração indireta.

A relação entre as resistências aumenta com o valor da resistência à compressão, comportamento contrário ao observado nos ensaios com CPs cilíndricos. Todavia, nota-se uma tendência da resistência à tração ser em torno de $10 \%$ da resistência à compressão, calculada em relação à área líquida. A Figura 4.2 apresenta o gráfico obtido com os valores desses ensaios, com a curva de tendência exponencial e curva teórica sugerida por Cheema e Klingner (1986).

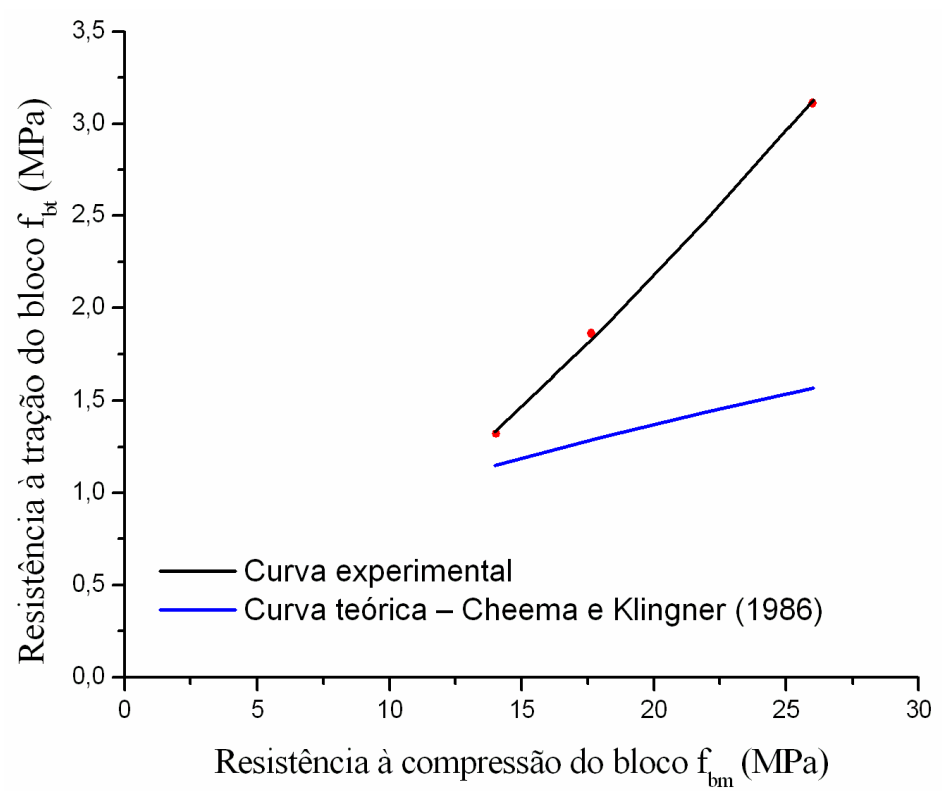

Figura 4.2 - Valores da resistência à tração e à compressão dos blocos vazados de concreto $\mathrm{e}$ curva teórica sugerida por Cheema e Klingner (1986), adaptada para o cálculo da resistência à compressão em relação a área líquida. 
A curva teórica apresenta um menor crescimento da resistência à tração do bloco quando aumentada a sua resistência à compressão, inclusive com a relação entre as resistências diminuindo com o aumento do valor da resistência à compressão, mesma tendência observada nos ensaios de corpos-de-prova de concreto. A resistência à tração, nesse caso, tem valor entre $6 \%$ e $8 \%$ da resistência à compressão.

Paralelamente, analisa-se comportamento da resistência à compressão e tração desses blocos em função das resistências do concreto que o constituem. A Tabela 4.3 e a Tabela 4.4 apresentam os valores obtidos nos ensaios.

Tabela 4.3 - Resistência à compressão de blocos e corpos-de-prova $10 \times 20 \mathrm{~cm}$.

\begin{tabular}{|c|c|c|c|}
\hline Grupo & $\begin{array}{c}\mathrm{f}_{\mathrm{cm}} \\
(\mathrm{MPa})\end{array}$ & $\begin{array}{c}\mathrm{f}_{\mathrm{bm}} \\
(\mathrm{MPa})\end{array}$ & $\frac{f_{b m}}{f_{c m}}$ \\
\hline \multirow{2}{*}{10} & 14,1 & 14,0 & 0,99 \\
\hline & 15,4 & 12,6 & 0,82 \\
\hline \multirow{2}{*}{20} & 18,0 & 16,5 & 0,92 \\
\hline & 20,6 & 17,7 & 0,86 \\
\hline \multirow{2}{*}{30} & 30,9 & 26,0 & 0,84 \\
\hline & 35,9 & 24,4 & 0,68 \\
\hline
\end{tabular}

Tabela 4.4 - Resistência à tração de blocos e corpos-de-prova $10 \times 20 \mathrm{~cm}$.

\begin{tabular}{|c|c|c|c|}
\hline Grupo & $\begin{array}{c}\mathrm{f}_{\mathrm{ct}, \mathrm{sp}} \\
(\mathrm{MPa})\end{array}$ & $\begin{array}{c}\mathrm{f}_{\mathrm{bt}, \mathrm{sp}} \\
(\mathrm{MPa})\end{array}$ & $\frac{f_{b t, s p}}{f_{c t, s p}}$ \\
\hline 10 & 1,9 & 1,3 & 0,68 \\
\hline 20 & 2,2 & 1,9 & 0,86 \\
\hline \multirow{2}{*}{30} & 2,7 & 3,1 & 1,15 \\
\hline & 3,1 & 3,4 & 1,10 \\
\hline
\end{tabular}

As relações entre as resistências à compressão do bloco inclinam-se a diminuir com o aumento da resistência, ao contrário, as relações entre estas resistências à tração tendem a aumentar. Os comportamentos descritos são apresentados na Figura 4.3. 


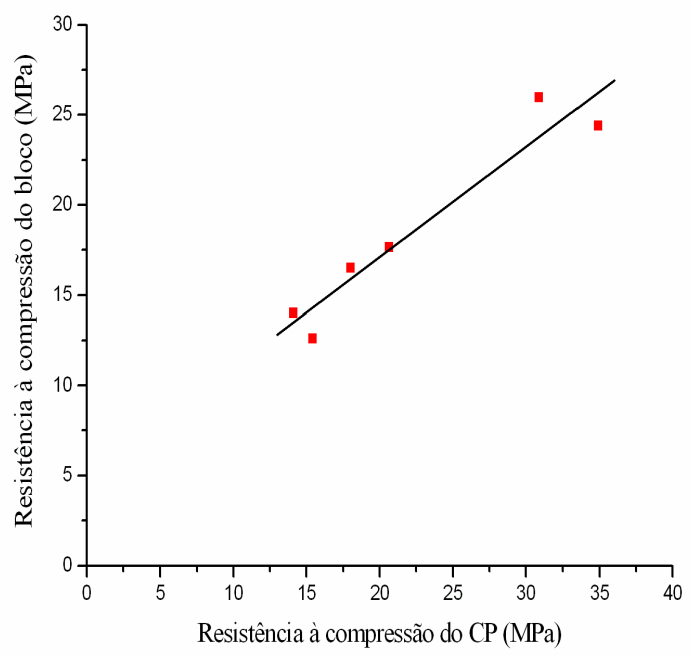

(a)

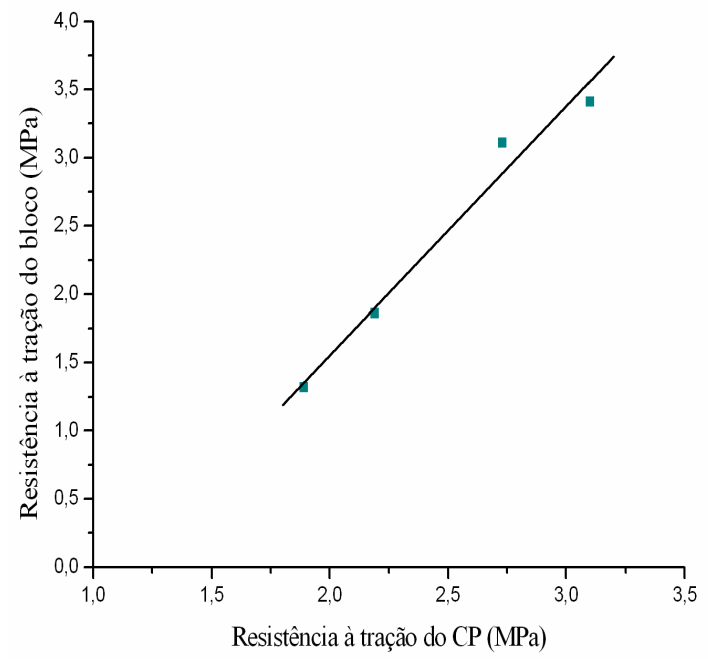

(b)

Figura 4.3 - Evolução das resistências à compressão e à tração do bloco em função da variação da resistência do concreto.

\subsection{Resistência à compressão e deformabilidade de blocos e corpos- de-prova}

A seguir, analisam-se os resultados de cada um dos grupos de resistência. As curvas tensão $\mathrm{x}$ deformação dos ensaios com blocos referem-se à numeração apresentada na Figura 4.4.

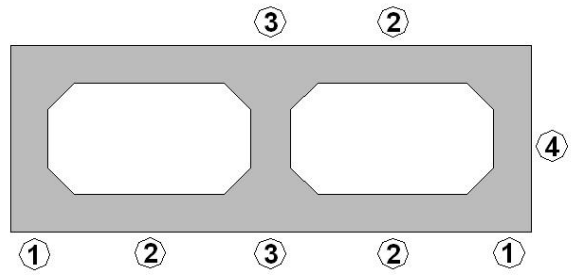

Figura 4.4 - Numeração correspondente à instrumentação utilizada nos ensaios com blocos.

\subsubsection{Grupo 10}

Na Tabela 4.5 apresentam-se os resultados obtidos nos ensaios de resistência à compressão com corpos-de-prova de dimensões distintas, seus módulos de elasticidade e a deformação apresentada na ruptura. A resistência à tração do concreto, obtida por meio da Equação (4.1) é de 1,8 MPa. 
Tabela 4.5 - Propriedades mecânicas dos corpos -de-prova - grupo 10.

\begin{tabular}{ccccc}
\hline Corpo-de-prova & $\begin{array}{c}\text { Resistência } \\
\text { média } \\
\mathrm{f}_{\mathrm{cm}}(\mathrm{MPa})\end{array}$ & $\begin{array}{c}\mathrm{f}_{\mathrm{cm}(15 \times 30)} \\
\mathrm{f}_{\mathrm{cm}}\end{array}$ & $\begin{array}{c}\text { Deformação na } \\
\text { ruptura }(\mu)\end{array}$ & $\begin{array}{c}\text { Módulo de } \\
\text { elasticidade } \\
\mathrm{E}_{\mathrm{c}}{ }^{1}(\mathrm{MPa})\end{array}$ \\
\hline 15 x 30 & 15,4 & 1,00 & 3017 & 12958 \\
$10 \times 20$ & 17,3 & 0,89 & 2910 & 16199 \\
$5 \times 10$ & 19,9 & 0,77 & 2820 & 15845 \\
Cubos 10 x 10 & 21,1 & 0,73 & 3760 & 17461 \\
Prismáticos 3 x 6 & 22,1 & 0,70 & 2177 & 31380 \\
\hline $\mathrm{E}_{\mathrm{c}}{ }^{1}$ Módulo de elasticidade do concreto. & & &
\end{tabular}

O valor da resistência média à compressão de cada elemento depende de sua geometria, sendo obtido para os CPs com menor relação altura-espessura (dimensão da base) maiores valores de resistência. Este fato se deve à influência do efeito de confinamento exercido pelas placas de ensaio sobre o elemento. Como as relações diâmetro:altura dos CPs cilíndricos são iguais (1:2), quanto menor a altura destes, maior será a resistência obtida em função das menores dimensões e, conseqüentemente, da maior probabilidade de existência de falhas no concreto (efeito de escala). Atribui-se o maior valor da resistência dos cubos à sua configuração geométrica e relação entre as dimensões (1:1:1); fato semelhante ocorre com os CPs prismáticos que possuem relação entre as suas dimensões de 1:2:2 e reduzida altura $(6 \mathrm{~cm})$.

A relação entre a resistência dos CPs cilíndricos com diâmetro de $15 \mathrm{~cm}$ e 10 cm é de 0,89. Neville (1997) descreve que o efeito de restrição das placas da prensa prolonga-se por toda a altura do cubo, mas não atinge toda a altura dos cilindros. Cita ainda que a resistência do cilindro $(15 \times 30 \mathrm{~cm})$ é em torno de $80 \%$ da resistência dos cubos (geralmente de aresta de $15 \mathrm{~cm}$ ), contudo essa relação aumenta com o aumento da resistência. Nestes ensaios, os cubos tinham aresta de $10 \mathrm{~cm}$ e a relação de sua resistência com a resistência do CP 15 x $30 \mathrm{~cm}$ ficou em 0,73 .

As deformações próximas à tensão de ruptura são aproximadamente de $3000 \mu$, com os CPs cúbicos apresentando valor um pouco maior e os CPs prismáticos um valor pouco menor.

Os módulos de elasticidade dos CPs cilíndricos têm valor mais alto à medida que a altura decresce, assim como quando a resistência aumenta. O aumento da resistência nos CPs prismáticos acarretou um grande aumento do módulo de elasticidade. As curvas tensão x deformação para as diversas geometrias de corpos-deprova são apresentadas na Figura 4.5a. Na Figura 4.5b apresentam-se as curvas tensão- 
deformação longitudinal e transversal obtidas no ensaio de CPs cilíndricos $10 \times 20 \mathrm{~cm}$. O coeficiente de Poisson é igual a 0,19.

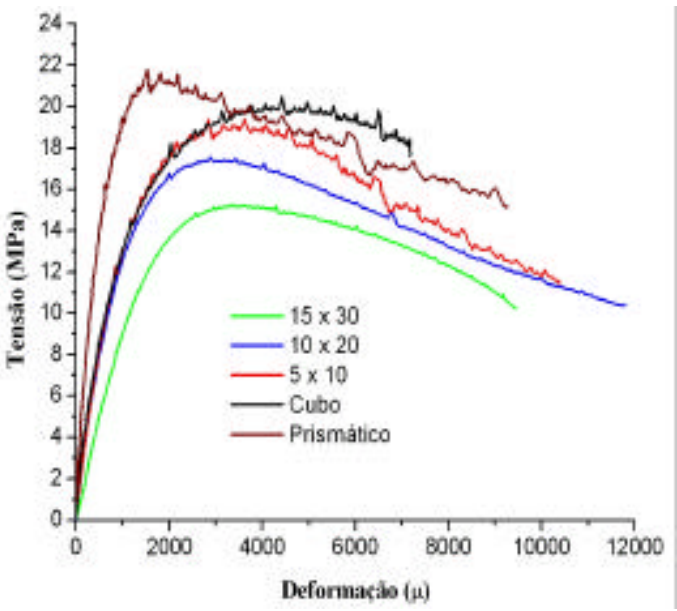

(a)

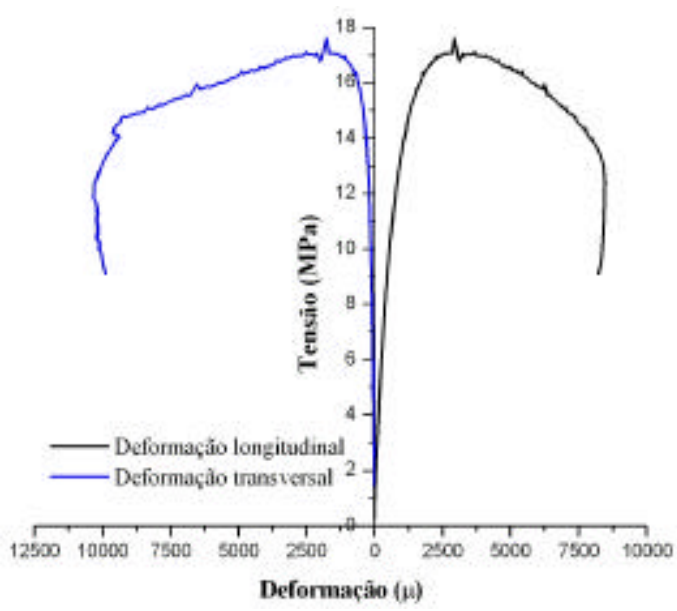

(b)

Figura 4.5 - Curvas tensão x deformação dos corpos-de-prova de diferentes geometrias (a). Curvas tensão x deformação longitudinal e transversal de CP 10 x $20 \mathrm{~cm}$ (b) - grupo 10 .

Ensaiaram-se três blocos de concreto, com a mesma idade dos CPs, determinando suas deformações ao longo da parede longitudinal e do septo transversal. A Tabela 4.6 resume os valores obtidos referentes à numeração apresentada na Figura 4.4 .

As deformações do bloco, quando analisados pontos distintos, são diferentes devido à influência exercida pela geometria do bloco. Os pontos 1 e 4, localizados na extremidade da parede longitudinal e no centro do septo transversal, respectivamente, são os que apresentam as menores deformações. Como observado na Figura 4.4, o ponto 1 não corresponde à região dos vazios do bloco e o ponto 4 situa-se a uma distância pequena entre as paredes longitudinais, o que justifica, em parte, a diferença dos valores obtidos. Os pontos 2 e 3 apresentam valores de deformações próximos. Por estar localizado na região do vazio do bloco, o ponto 2, apresenta as maiores deformações, influenciando ainda a deformação do ponto 3. As deformações nos pontos 2 e 3, até um nível equivalente a $40 \%$ da tensão máxima, são aproximadamente 7 vezes maiores que os valores obtidos nos pontos 1 e 4 . Cabe ressaltar que o valor de tensão expresso refere-se à tensão média aplicada na área líquida do bloco e que ela não se distribui uniformemente pelo bloco. Esse valor representa apenas um parâmetro geral para comparações. 
Tabela 4.6 - Propriedades mecânicas dos blocos de concreto - grupo 10 .

\begin{tabular}{|c|c|c|c|}
\hline \multirow{2}{*}{$\begin{array}{c}\text { Resistência } \\
\text { média }^{1} \\
\mathrm{f}_{\mathrm{bm}}(\mathrm{MPa})\end{array}$} & \multirow{2}{*}{ Pontos } & \multicolumn{2}{|c|}{ Deformação $(\mu)$} \\
\hline & & Ruína & $40 \%$ tensão máxima \\
\hline \multirow{4}{*}{16,8} & 1 & 1840 & 104 \\
\hline & 2 & 6683 & 821 \\
\hline & 3 & 7549 & 917 \\
\hline & $4^{2}$ & 2136 & 138 \\
\hline
\end{tabular}

As correlações entre as resistências dos elementos são apresentadas na Figura 4.6. A resistência do CP $10 \times 20 \mathrm{~cm}$ possui o valor mais próximo à resistência do bloco. A relação entre a resistência do CPs cilíndricos 15 x $30 \mathrm{~cm}$ e 10 x $20 \mathrm{~cm}$ é próxima de 0,90 e entre o CP cilíndrico 10 x $20 \mathrm{~cm}$ e o cubo (de aresta $10 \mathrm{~cm}$ ) é de 0,82, próximos aos valores mencionados por Neville (1997).

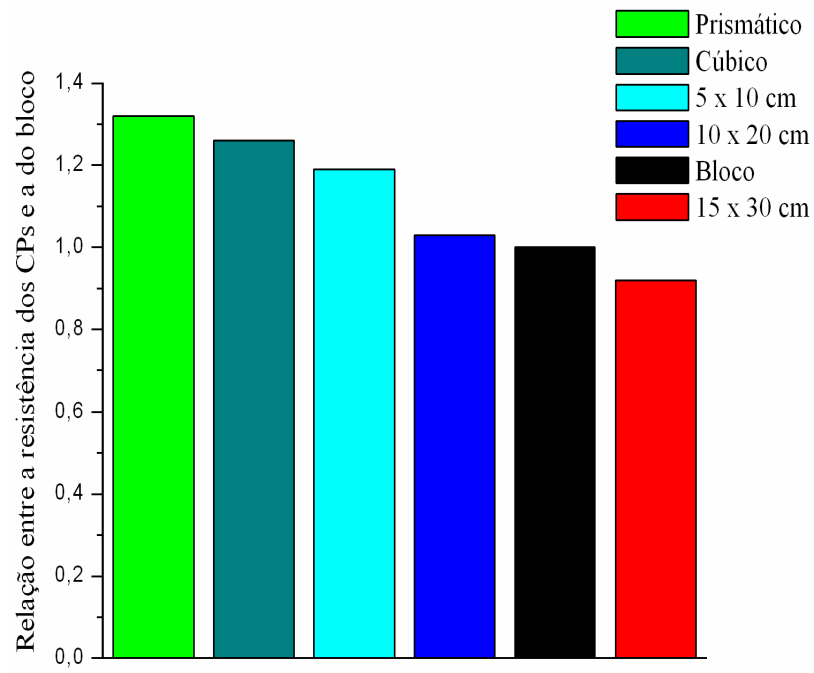

Figura 4.6 - Relação entre as resistências médias dos corpos-de-prova e bloco - grupo 10

As curvas tensão x deformação ${ }^{2}$ obtidas nos ensaios com os blocos vazados de concreto são apresentadas na Figura 4.7, em que se podem observar as diferenças da inclinação inicial das curvas. Após atingir a força máxima, as deformações nos pontos 2 e 3 tendem a crescer mais que as deformações dos pontos 1 e 4 . Novamente, cabe enfatizar que essas tensões referem-se à área líquida do bloco e não representam a intensidade real que atua em cada ponto. No bloco, a tensão em cada ponto não é

\footnotetext{
2 O eixo das ordenadas dos gráficos tensão x deformação refere-se à tensão média relativa à área líquida do bloco.
} 
constante, o que leva a diferentes valores de deformação já que as propriedades do concreto são homogêneas em todo o elemento.

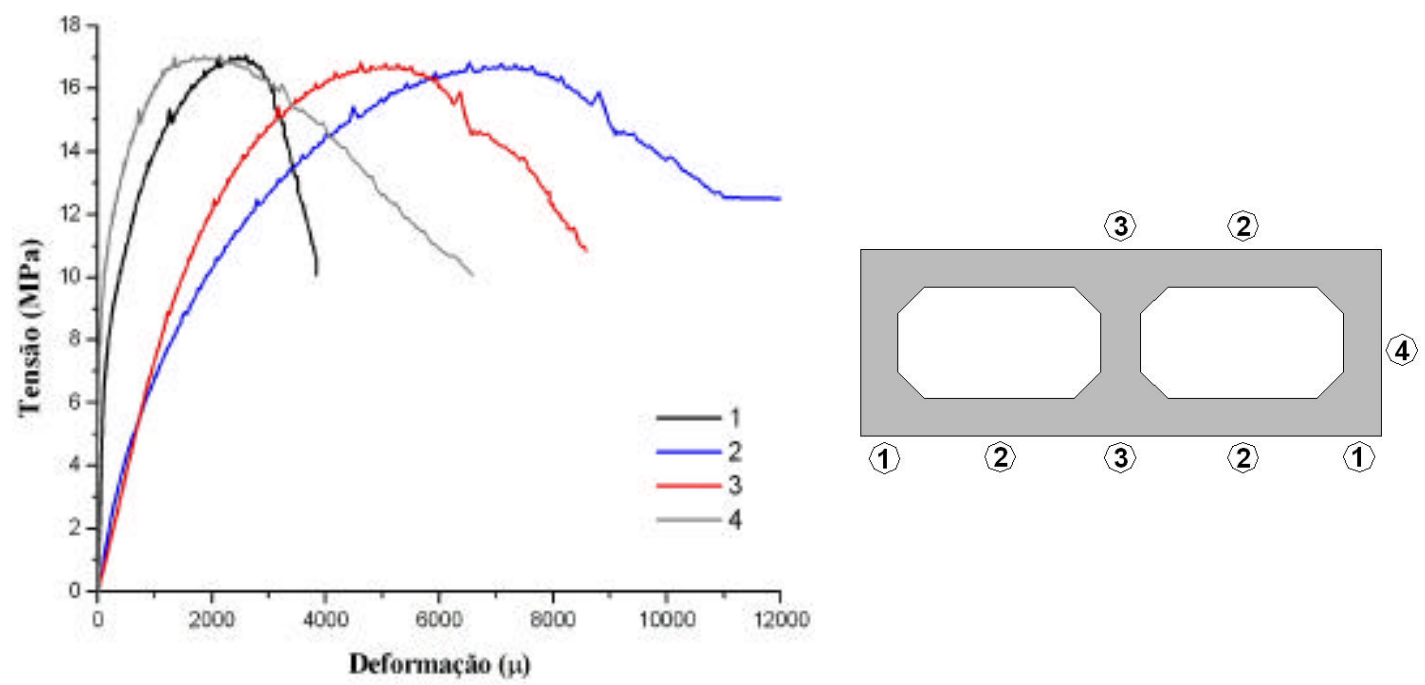

Figura 4.7 - Curvas tensão x deformação do bloco vazado de concreto - grupo 10.

A curva tensão $x$ deformação transversal não é condizente com o comportamento do bloco, apresentando baixa deformação inicial, com trechos alternados de alongamento e encurtamento, enquanto esperavam-se apenas alongamentos - representativo da deformação transversal do bloco quando submetido à compressão. A Figura 4.8a ilustra a curva tensão x deformação transversal.

As deformações obtidas por meio dos extensômetros elétricos de resistência não se mostraram regulares, pois as curvas não apresentaram comportamento homogêneo. Esses instrumentos são bastante sensíveis à fissuração, o que resultou em curvas que apresentam deformações distintas com trechos de alongamento e encurtamento. Os deslocamentos obtidos no topo do bloco estão no gráfico da Figura 4.8b. De posse dos valores desses deslocamentos, pode-se estimar a deformação encontrada no topo do bloco, em relação as suas duas direções. A deformação transversal no septo e na parede longitudinal valem aproximadamente $1250 \mu$ a $40 \%$ da tensão máxima e $3000 \mu$ na ruína. 


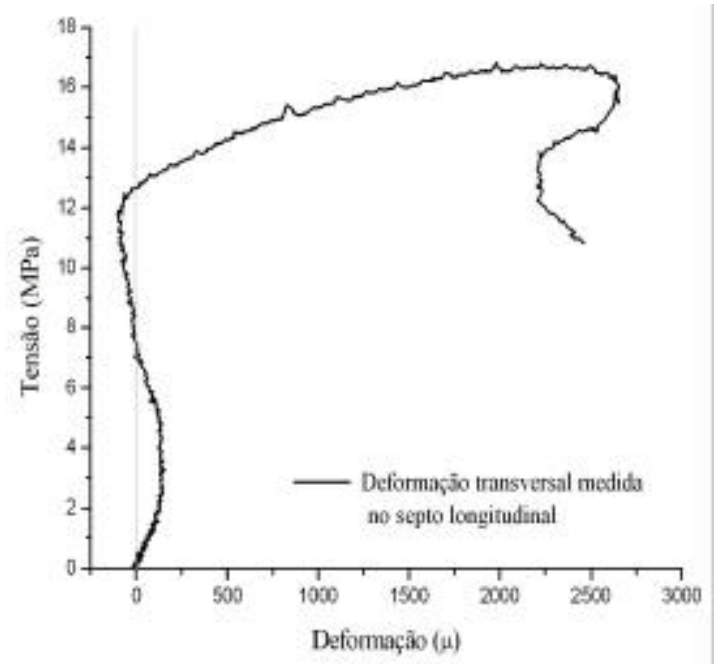

(a)

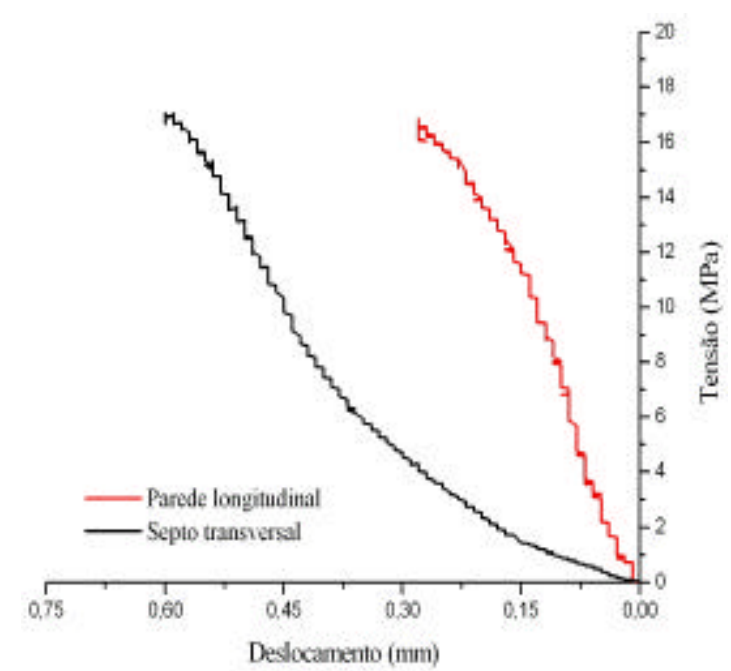

(b)

Figura 4.8 - Curva tensão $x$ deformação transversal (a). Curva tensão x deslocamento no topo do bloco (b).

O comportamento dos blocos, em cinco níveis de tensão, é representado por meio de linhas de deformação na Figura 4.9. $\sigma_{\mathrm{u}}$ representa a tensão máxima alcançada no ensaio. No início do ensaio, a 20\% da tensão máxima, as deformações nos pontos 1 e 4 são praticamente nulas, e a deformação no ponto central 3 é aproximadamente $60 \%$ maior que a obtida no ponto 2 . Até $40 \%$ da tensão máxima de ensaio, as deformações aumentam em direção ao centro do bloco. Nesse nível de tensão, a diferença de deformação entre os pontos 2 e 3 diminuem, sendo o valor de deformação maior $10 \%$ no ponto 3 que no ponto 4. Quando atingida $60 \%$ da tensão máxima, os pontos 1 e 4 continuam a apresentar as menores deformações e os pontos 2 e 3, situados na parte central do bloco, passam a apresentar valores mais elevados. A deformação entre os pontos 1 e 4, a partir desse nível até a tensão de ruptura, valem 10\%, 20\% e 35\% das deformações ocorridas no ponto central. A partir de $60 \%$ da tensão máxima até a tensão de ruína, o ponto 2 apresenta maiores deformações $10 \%$, 30\% e $20 \%$ maiores que o ponto 3. Vale ressaltar que as deformações obtidas principalmente a partir de $80 \%$ da tensão máxima são fortemente influenciadas pela intensa fissuração apresentada pelo bloco. 


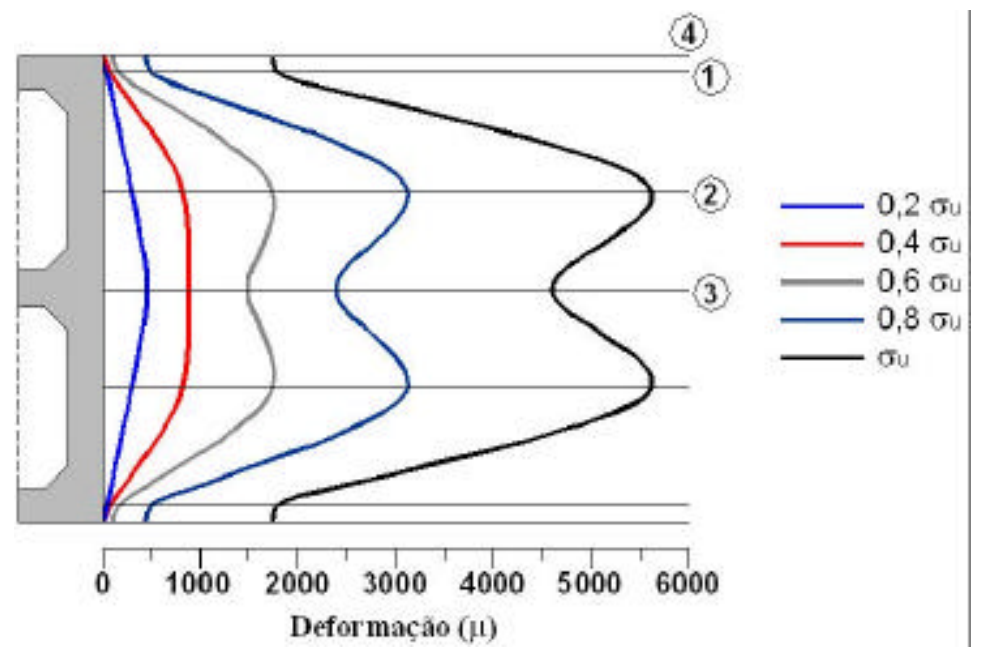

Figura 4.9 - Linhas de deformação do bloco de concreto - grupo 10.

\subsubsection{Grupo 20}

Procede-se análise semelhante para esse grupo de resistência, sendo apresentado na Tabela 4.7 o resumo dos resultados dos ensaios realizados com corposde-prova. $\mathrm{O}$ valor de $\mathrm{f}_{\mathrm{ct}, \mathrm{sp}}$ é $2,1 \mathrm{MPa}$.

Tabela 4.7 - Propriedades mecânicas dos corpos-de-prova - grupo 20.

\begin{tabular}{ccccc}
\hline Corpo-de-prova & $\begin{array}{c}\text { Resistência } \\
\text { média } \\
\mathrm{f}_{\mathrm{cm}}(\mathrm{MPa})\end{array}$ & $\begin{array}{c}\mathrm{f}_{\mathrm{cm}(15 \times 30)} \\
\mathrm{f}_{\mathrm{cm}}\end{array}$ & $\begin{array}{c}\text { Deformação na } \\
\text { ruptura }(\mu)\end{array}$ & $\begin{array}{c}\text { Módulo de } \\
\text { elasticidade } \\
\mathrm{E}_{\mathrm{c}}(\mathrm{MPa})\end{array}$ \\
\hline 15 x 30 & 18,6 & 1,00 & 3454 & 17076 \\
$10 \times 20$ & 20,4 & 0,91 & 2707 & 19407 \\
$5 \times 10$ & 22,3 & 0,83 & 2961 & 17458 \\
Cubos 10 x 10 & 26,6 & 0,70 & 5117 & 33574 \\
Prismáticos 3 x 6 & 24,6 & 0,76 & 1798 & 38182 \\
\hline
\end{tabular}

Os valores obtidos, se considerado o nível de resistência, não diferem significativamente dos encontrados no grupo 10. A única diferença apresentada é em relação à resistência do cubo que apresenta valor superior à resistência dos CPs prismáticos.

As deformações quando atingida a ruína estão na ordem de $3000 \mu$; os cubos apresentam maiores deformações $(5000 \mu)$ e os CPs prismáticos valores mais baixos $(1800 \mu)$. Apesar da maior resistência, o corpo-de-prova cúbico apresenta menor valor do módulo de elasticidade que o $\mathrm{CP}$ prismático, em decorrência de suas maiores deformações. 
As curvas tensão $\mathrm{x}$ deformação dos corpos-de-prova são apresentadas na Figura 4.10.

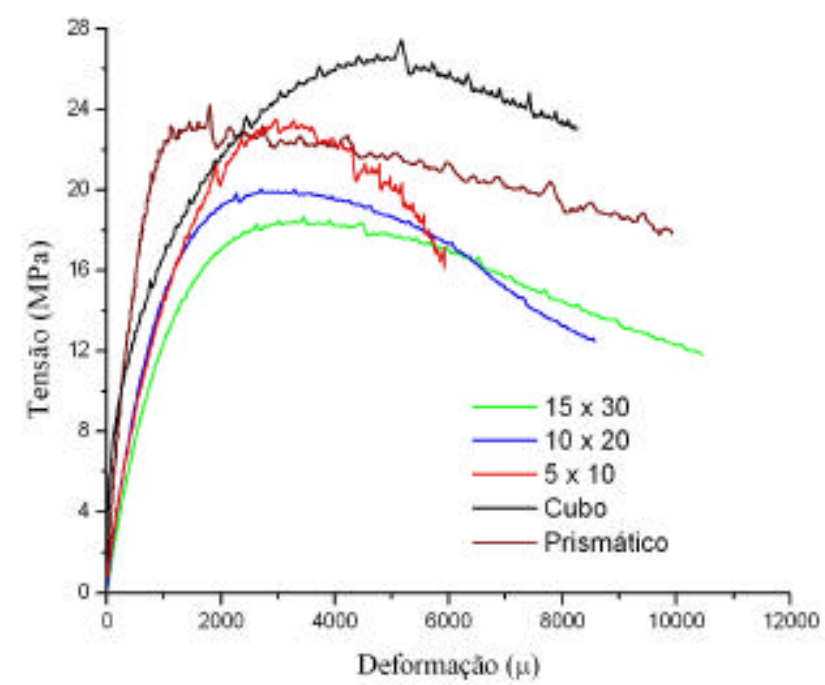

Figura 4.10 - Curvas tensão x deformação dos corpos -de-prova de diferentes geometrias - grupo 20.

Os valores obtidos nos ensaios com os blocos são apresentados na Tabela 4.8. Os blocos apresentam distintas deformações ao longo de suas paredes, apresentando resultados semelhantes aos obtidos no grupo 10. As menores deformações são obtidas nos pontos 1 e 4 e as maiores nos pontos 2 e 3 . O ponto 3 apresenta maior valor que o do ponto 2 , a $40 \%$ da tensão máxima. A diferença percentual entre os valores de deformação obtidos nos pontos centrais em relação às obtidas nos pontos 1 e 4 , são próximas às encontradas nos blocos do grupo 10.

As relações entre as resistências dos elementos são apresentadas na Figura 4.11 .

Tabela 4.8 - Propriedades mecânicas dos blocos de concreto - grupo 20.

\begin{tabular}{cccc}
\hline $\begin{array}{c}\text { Resistência } \\
\text { média }\end{array}$ & Pontos & \multicolumn{2}{c}{ Deformação $(\mu)$} \\
\cline { 3 - 4 } $\mathrm{f}_{\mathrm{bm}}(\mathrm{MPa})$ & & Ruína & 40\% Tensão máxima \\
\hline \multirow{2}{*}{19,8} & 1 & 1801 & 118 \\
& 2 & 5889 & 834 \\
& 3 & 4511 & 1059 \\
& $4^{1}$ & 1562 & 219 \\
\hline
\end{tabular}




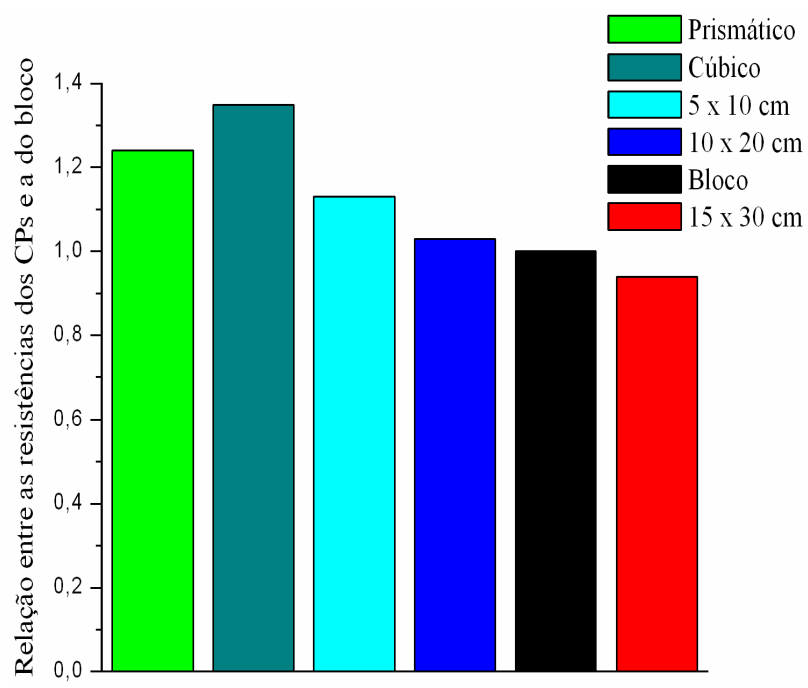

Figura 4.11 - Relação entre as resistências médias dos corpos-de-prova e bloco - grupo 20

As relações entre as resistências dos blocos e dos corpos-de-prova não diferem significativamente dos valores encontrados no grupo 10, inclusive permanecendo o mesmo valor quando comparados os valores dos CPs cilíndricos 10 x $20 \mathrm{~cm}$ com os valores dos blocos. A diferença ocorre nas relações com a resistência do cubo, em razão do seu valor mais elevado valor.

A Figura 4.12 apresenta as curvas tensão x deformação obtidas nos ensaios com blocos. Diferencia-se a inclinação das curvas 1 e 4 em relação às curvas 2 e 3.

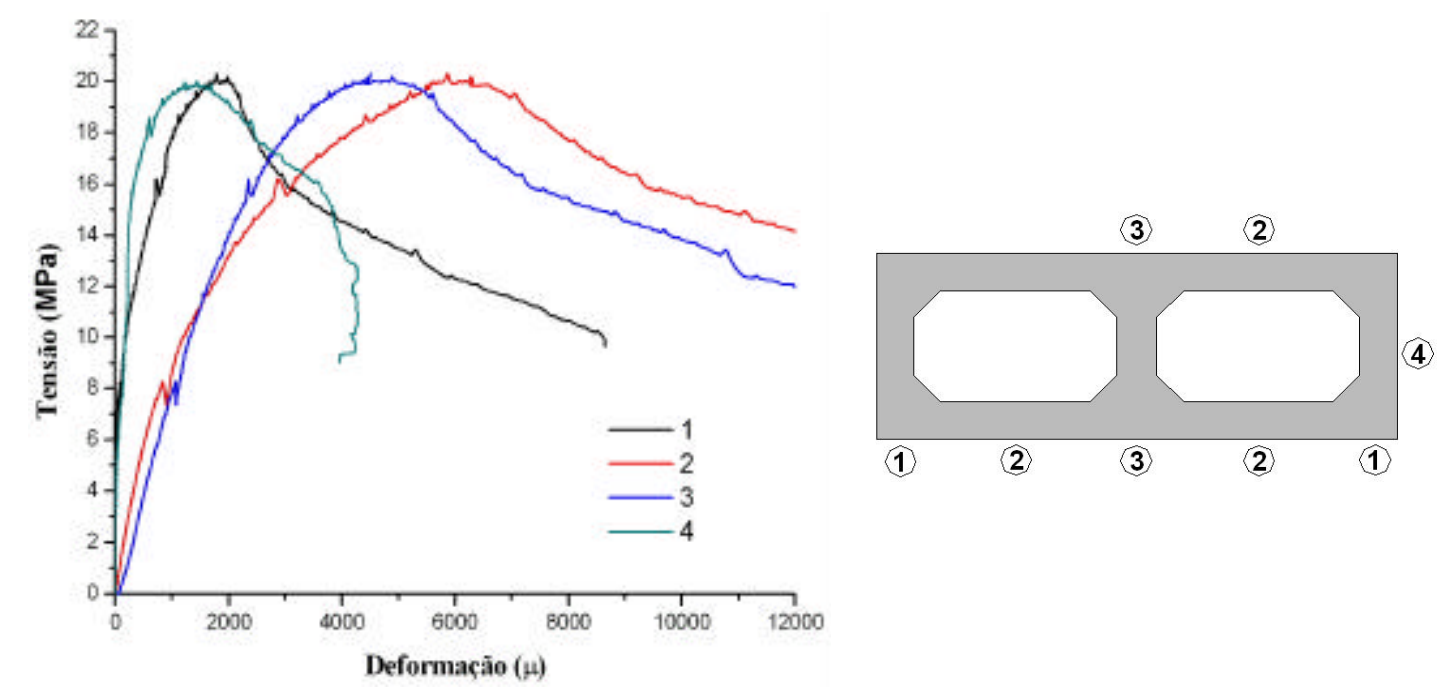

Figura 4.12 - Curvas tensão x deformação do bloco vazado de concreto - grupo 20.

As deformações dos blocos, em níveis de tensão em relação à tensão máxima no ensaio $\sigma_{\mathrm{u}}$, são apresentadas na Figura 4.13. O comportamento das curvas se assemelha com os obtidos com os blocos do grupo 10. As deformações nos pontos 1 e 4 são baixas em relação às obtidas nos pontos 2 e 3, até $40 \%$ da tensão máxima. A 
deformação no ponto 3 , a $20 \%$ e $40 \%$ da tensão de ruptura, é maior $65 \%$ e $30 \%$ que a obtida no ponto 2; nos demais níveis este ponto apresenta deformação maior que o ponto 3 , com valor entre $10 \%$ a $30 \%$. As deformações nos pontos 1 e 4 , a partir de $40 \%$ da tensão máxima também aumentam, com valores variando entre $15 \%$ e $25 \%$ em relação aos obtidos na região central do bloco.

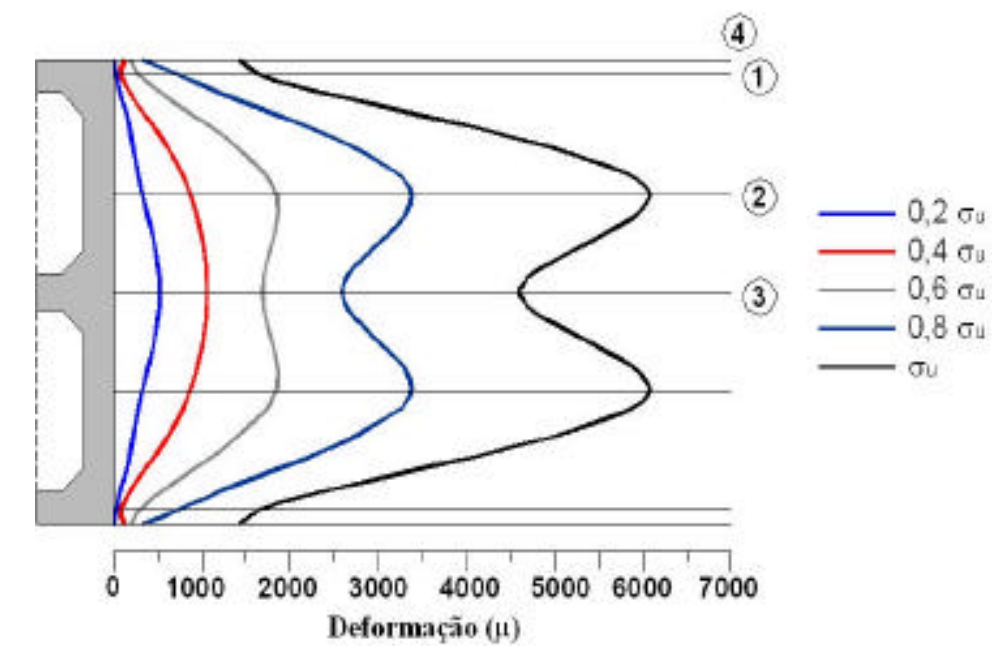

Figura 4.13 - Linhas de deformação do bloco de concreto - grupo 20.

\subsubsection{Grupo 30}

Na Tabela 4.9 apresentam-se os resultados obtidos nos ensaios com corpos-deprova, que são coerentes com a geometria dos corpos-de-prova. $\mathrm{O}$ valor da resistência à tração do concreto é de 3,3 $\mathrm{MPa}$. Cabe ressaltar que mais uma vez houve variação na resistência dos cubos que apresenta valor inferior aos CPs prismáticos.

Tabela 4.9 - Propriedades mecânicas dos corpos-de-prova - grupo 30.

\begin{tabular}{ccccc}
\hline Corpo-de-prova & $\begin{array}{c}\text { Resistência } \\
\text { média } \\
\mathrm{f}_{\mathrm{cm}}(\mathrm{MPa})\end{array}$ & $\begin{array}{c}\mathrm{f}_{\mathrm{cm}(15 \times 30)} \\
\mathrm{f}_{\mathrm{cm}}\end{array}$ & $\begin{array}{c}\text { Deformação na } \\
\text { ruptura }(\mu)\end{array}$ & $\begin{array}{c}\text { Módulo de } \\
\text { elasticidade } \\
\mathrm{E}_{\mathrm{c}}(\mathrm{MPa})\end{array}$ \\
\hline 15 x 30 & 36,6 & 1,00 & 3546 & 19807 \\
$10 \times 20$ & 41,5 & 0,88 & 3061 & 25484 \\
$5 \times 10$ & 46,6 & 0,79 & 2715 & 23609 \\
Cubos 10 x 10 & 52 & 0,70 & 4783 & 20518 \\
Prismáticos 3 x 6 & 54,4 & 0,67 & 1896 & 32533 \\
\hline
\end{tabular}

As deformações dos CPs cilíndricos, na ruína, mantiveram-se em torno de $3000 \mu$. Nos três grupos de resistência analisados nota-se que as maiores deformações na ruína foi apresentado pelos CPs cúbicos e as menores pelos CPs prismáticos. Em relação aos módulos de elasticidade, os CPs prismáticos apresentam os valores mais 
altos, seguidos dos CPs cúbicos - com exceção deste grupo. Os CPs cilíndricos apresentam uma menor variação de resistência com a variação de suas dimensões.

Os corpos-de-prova de diferentes geometrias têm suas curvas tensão $\mathrm{x}$ deformação ilustradas na Figura 4.14.

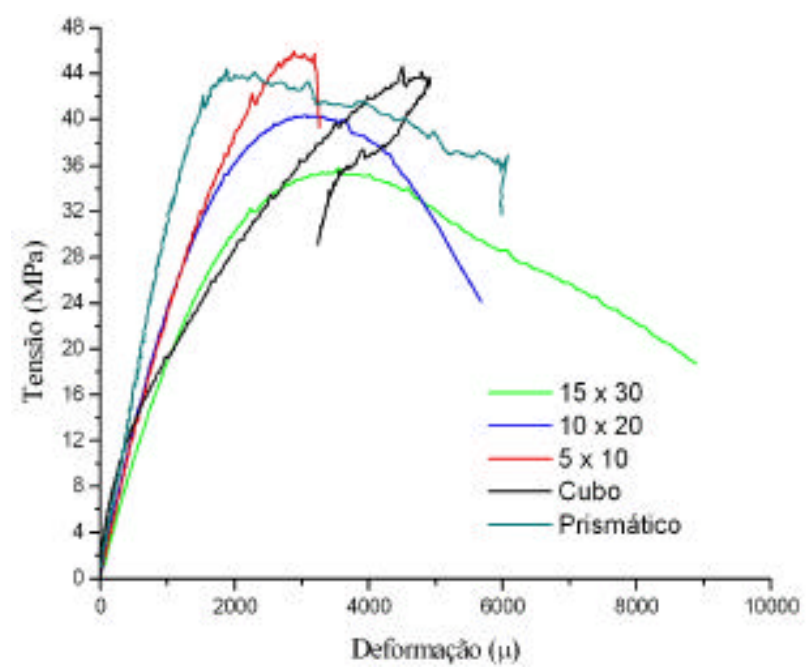

Figura 4.14 - Curvas tensão x deformação dos corpos-de-prova de diferentes geometrias - grupo 30.

As propriedades mecânicas dos blocos (Tabela 4.10), mostram-se coerentes com as obtidas nos grupos 10 e 20, no entanto, a deformação no ponto 2, a $40 \%$ da tensão máxima, é um pouco maior que a obtida no ponto 3. A variação provavelmente foi uma particularização do ensaio, não estando relacionada com o aumento da resistência do concreto blocos vazados de concreto. Destacam-se também os baixos valores obtidos nos pontos 1 e 4 . Com o aumento da resistência do concreto, reduziramse as deformações sob a tensão máxima de ensaio. As diferenças de deformações entre os pontos 2 e 3 e os pontos 1 e 4 têm o mesmo patamar das encontradas nos ensaios com os blocos do grupo 10 e 20.

Tabela 4.10 - Propriedades mecânicas dos blocos de concreto - grupo 30.

\begin{tabular}{cccc}
\hline $\begin{array}{c}\text { Resistência } \\
\text { média } \\
\mathrm{f}_{\mathrm{bm}}(\mathrm{MPa})\end{array}$ & Pontos & Ruína & 40\% tensão máxima \\
\cline { 3 - 4 } & 1 & 1408 & 173 \\
35,7 & 2 & 4227 & 1094 \\
& 3 & 3052 & 919 \\
& $4^{1}$ & 340 & 187 \\
\hline
\end{tabular}

A relação entre a resistência dos CPs e dos blocos apresentaram aumento, conforme ilustra a Figura 4.15. O CP 15 x $30 \mathrm{~cm}$ foi o que teve a sua resistência à 
compressão mais próxima à resistência dos blocos, e o CP $10 \times 20 \mathrm{~cm}$ passa a ter a relação de 1,03. Todavia, a relação entre os CPs cilíndricos 10 x $20 \mathrm{~cm}$ e 15 x $30 \mathrm{~cm}$ e entre o CP 10 x $20 \mathrm{~cm}$ e o cubo permaneceram estáveis. Todas as relações apresentam maiores valores que as obtidas nos grupos 10 e 20.

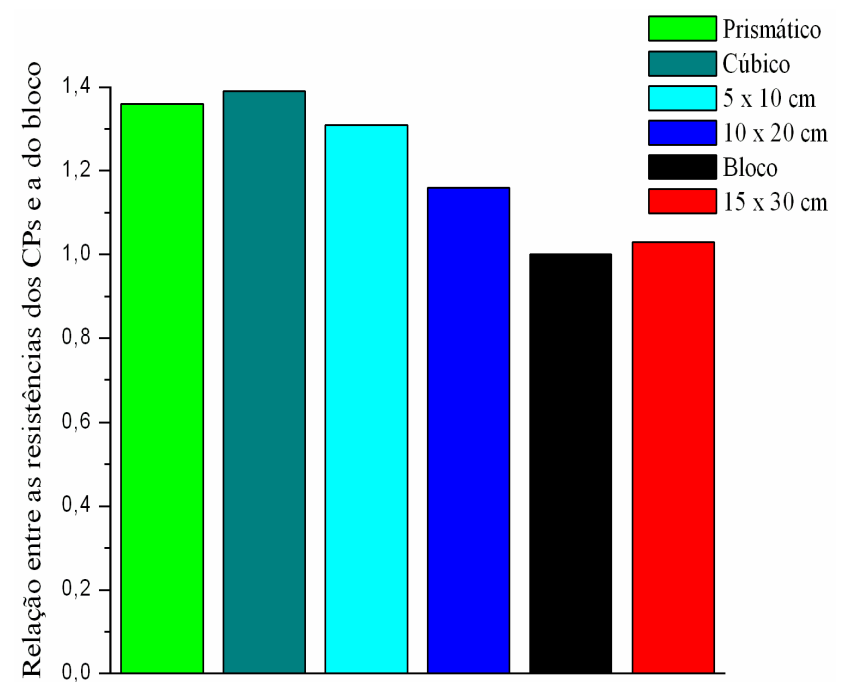

Figura 4.15 - Relação entre as resistências médias dos corpos-de-prova e bloco - grupo 30.

$\mathrm{Na}$ Figura 4.16 apresentam-se as curvas tensão $\mathrm{x}$ deformação em pontos distintos, obtidas nos ensaios com blocos. A mudança de comportamento das curvas $2 \mathrm{e}$ 3 ocorre a uma tensão relativa mais baixa que as identificadas nos grupos 10 e 20.

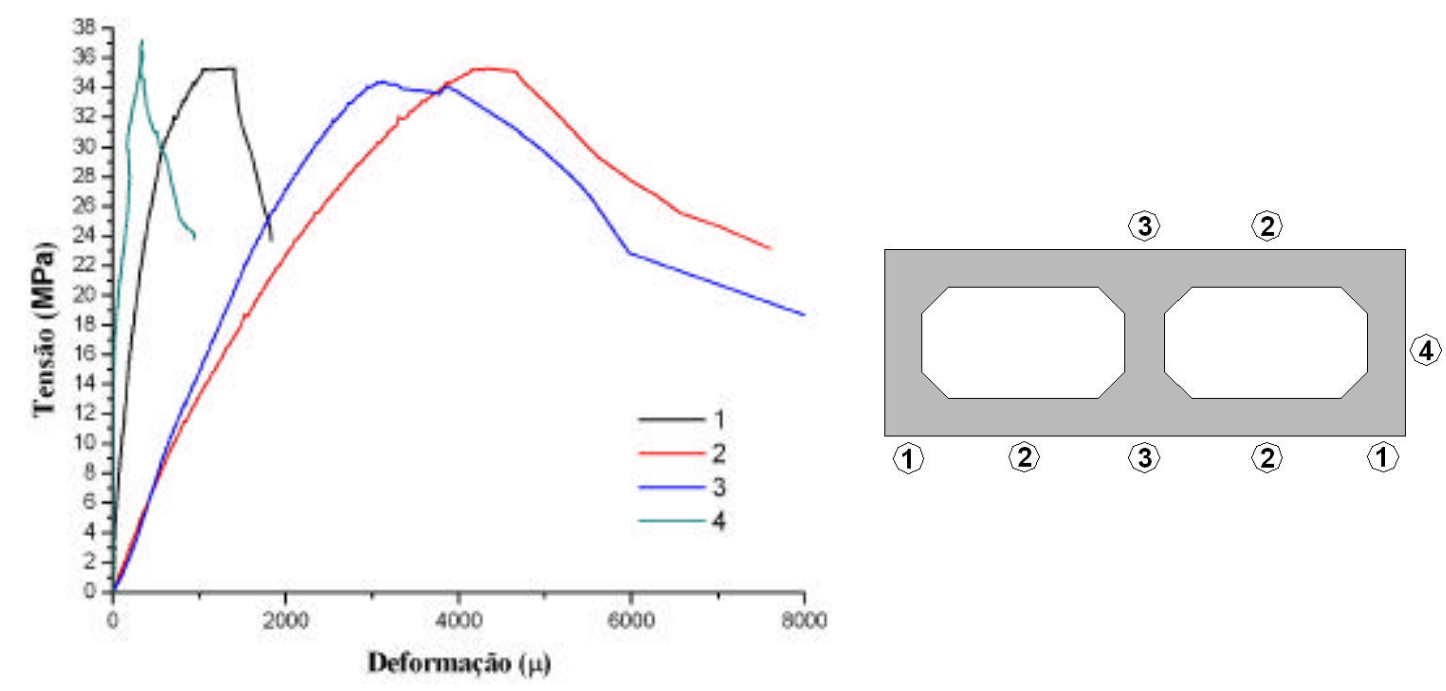

Figura 4.16 - Curvas tensão x deformação do bloco vazado de concreto - grupo 30 .

A Figura 4.17 apresenta as linhas de deformação dos blocos desse grupo de resistência, destacando-se menores valores de deformação em decorrência do maior valor da resistência do concreto. A diferença em relação aos exemplos anteriores é notada nas curvas referentes às tensões equivalentes a $20 \%$ e $40 \%$ da tensão máxima, em que as deformações no ponto 3 são menores que a do ponto 2 em até $15 \%$. Nesses 
níveis de tensão, as deformações nos pontos 1 e 4 valem aproximadamente $10 \%$ da deformação obtidas nos outro dois pontos do bloco; essa relação aumenta para até $25 \%$ na tensão de ruína. Os pontos 2 e 3 apresentam a diferença percentual equivalentes aos encontrados nos grupos 10 e 20 a partir de $60 \%$ da tensão máxima.

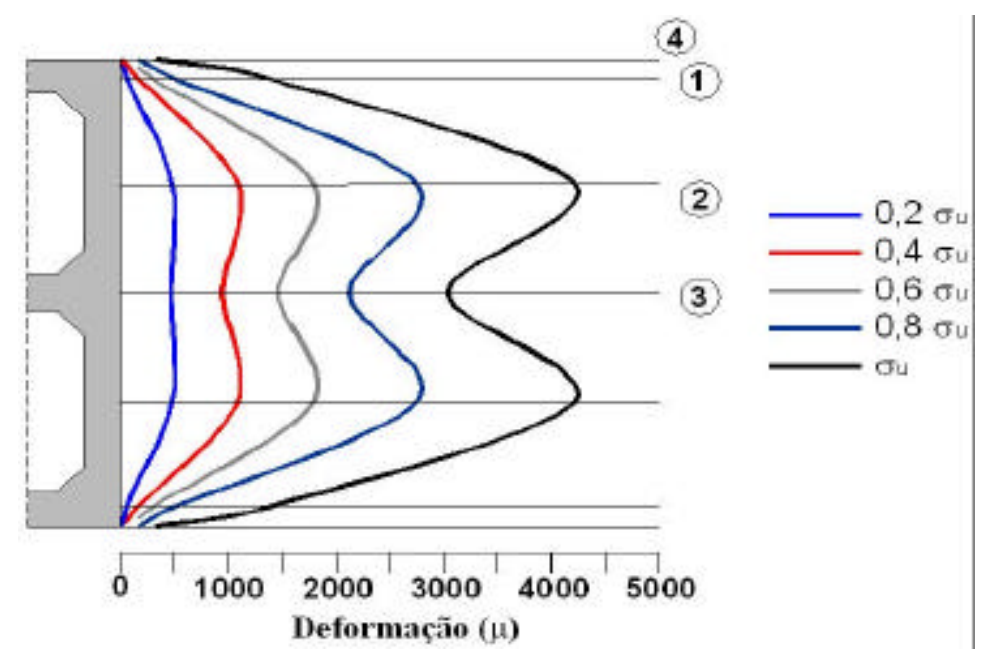

Figura 4.17 - Linhas de deformação do bloco de concreto - grupo 30.

\subsubsection{Considerações sobre os ensaios com blocos de concreto}

Os valores de resistência à compressão obtidos em corpos-de-prova cilíndricos 10 x $20 \mathrm{~cm}$ e 15 x $30 \mathrm{~cm}$ são os que mais se aproximam da resistência à compressão do bloco de concreto em relação à sua área líquida. As demais geometrias apresentam resistência maior que a resistência do bloco e módulos de elasticidade maiores que os obtidos com os CPs cilíndricos. A relação entre os valores de resistência à compressão obtida em corpos-de-prova cilíndricos 15 x $30 \mathrm{~cm}$ e 10 x $20 \mathrm{~cm}$, manteve-se constante, sendo inclusive utilizado no presente trabalho o fator 0,9 para converter alguns valores de resistência obtidos com estes CPs. Em relação aos valores do módulo de elasticidade, a relação entre estas duas geometrias está entre 0,78 e 0,88.

As formulações sugeridas pelo ACI 530-89 (1995), CEB-FIP (1990) e NBR 6118 (2003) conduz a valores distintos do módulo de elasticidade do concreto. A formulação americana apresenta os menores valores e mais próximos aos obtidos nas análises experimentais, conforme ilustra a Figura 4.18. Os módulos de elasticidade obtidos experimentalmente em CPs 10 × $20 \mathrm{~cm}$ e 15 x $30 \mathrm{~cm}$ apresentam os valores mais baixos, portanto não havendo super estimativa em relação aos valores teóricos.

O módulo de elasticidade do concreto com o qual é moldado o bloco não é o único fator influente nas deformações ocorridas ao longo de suas paredes. A geometria 
do bloco influência essa distribuição, fazendo com que após a aplicação da força pela máquina de ensaio a distribuição de tensões por todo o elemento não seja uniforme. Entretanto, atribui-se ao deslocamento não uniforme da placa de ensaio o fator mais relevante nos distintos valores de deformações obtidos. Nos ensaios realizados por Becica e Harris (1983) observa-se distribuição semelhante de deformações, inclusive em um nível de carregamento equivalente a $50 \%$ da força máxima, os valores de deformação nos pontos centrais são mais que cinco vezes maior que os encontrados nos pontos mais extremos. Nesses experimentos a espessura da placa e o diâmetro da prensa eram de aproximadamente $4,9 \mathrm{~cm}$ e $25 \mathrm{~cm}$, respectivamente. Os blocos possuíam dimensões de 19 × 19 × $39 \mathrm{~cm}$. Aparentemente, o aumento da espessura da placa leva a uma maior uniformização das tensões que o aumento do diâmetro de aplicação da força de ensaio.

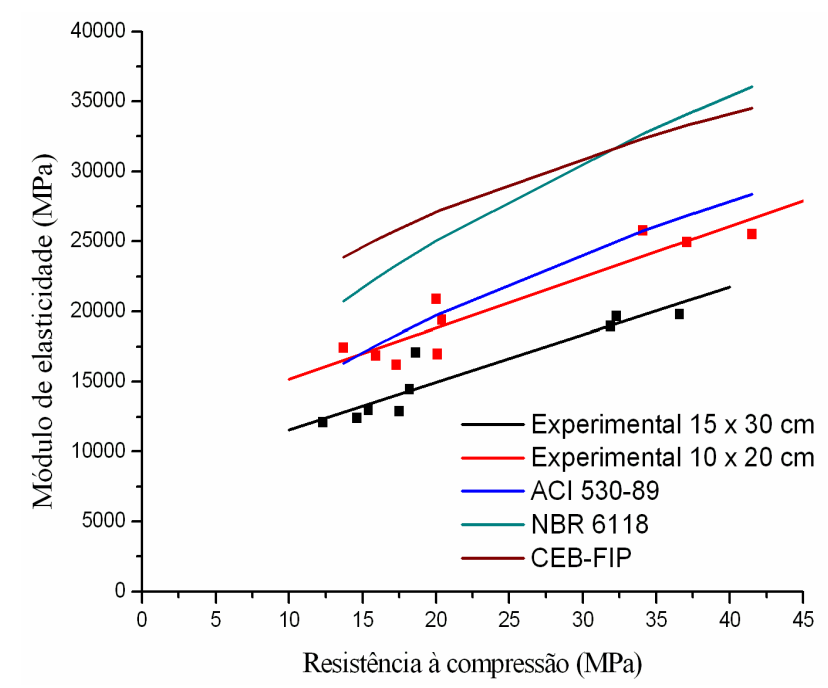

Figura 4.18 - Curvas teóricas e experimentais do módulo de elasticidade x resistência à compressão do concreto, obtidas em corpos-de-prova cilindricos.

A resistência dos blocos vazados de concreto está relacionada com a resistência obtida em corpos-de-prova cilíndricos 10 × $20 \mathrm{~cm}$ e 15 x $30 \mathrm{~cm}$ conforme distribuição apresentada ma Figura 4.19. Para o intervalo de resistência, duas curvas - uma linear e outra exponencial - representam tal distribuição com a mesma variação. As expressões que definem tais curvas, referentes aos CPs 10 x $20 \mathrm{~cm}$, são representadas pelas Equações (4.3) e (4.4).

$$
\begin{gathered}
\mathrm{f}_{\mathrm{b}}=0,72 \mathrm{f}_{\mathrm{c}}+3,34 \\
\mathrm{f}_{\mathrm{b}}=1,5 \mathrm{f}_{\mathrm{c}}^{0,8271}
\end{gathered}
$$


A ruína dos blocos e corpos-de-prova inicia-se com fissuras verticais nas faces dos elementos ocorrendo posterior esmagamento, que resulta em uma configuração tronco-piramidal. Ao se aumentar a resistência do concreto o seu módulo de elasticidade aumenta e o modo de ruína é alterado, tornando-se mais frágil e menos dúctil.

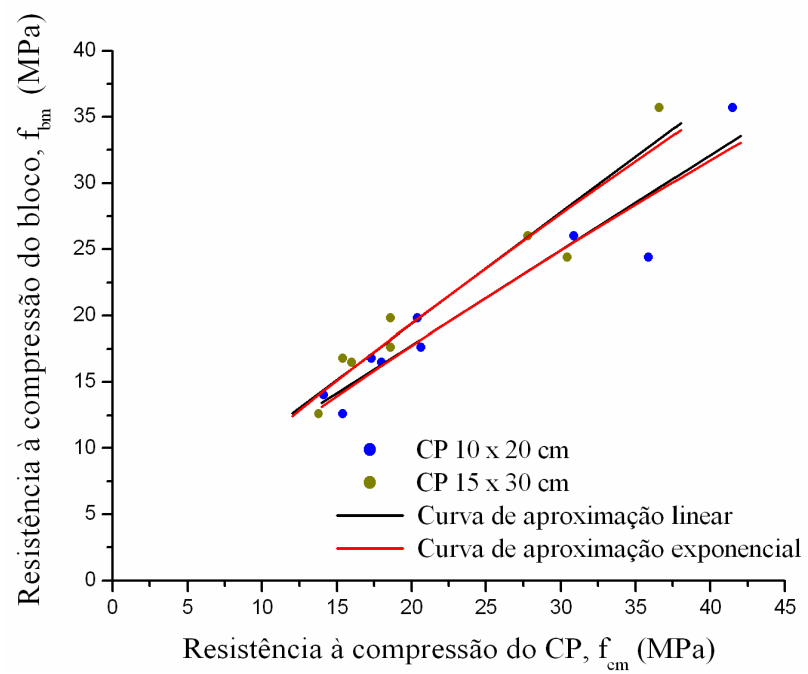

Figura 4.19 - Relação entre a resistência do bloco e dos corpos-de-prova cilíndricos 10 x $20 \mathrm{~cm}$ e $15 \times 30 \mathrm{~cm}$.

Na Figura 4.20 apresenta-se a correlação entre a resistência à tração do concreto e a resistência à compressão dos blocos. Essa curva possui uma inclinação maior que as apresentadas no gráfico da Figura 4.19, indicando a maior influência do aumento da resistência à tração do concreto na resistência à compressão do bloco.

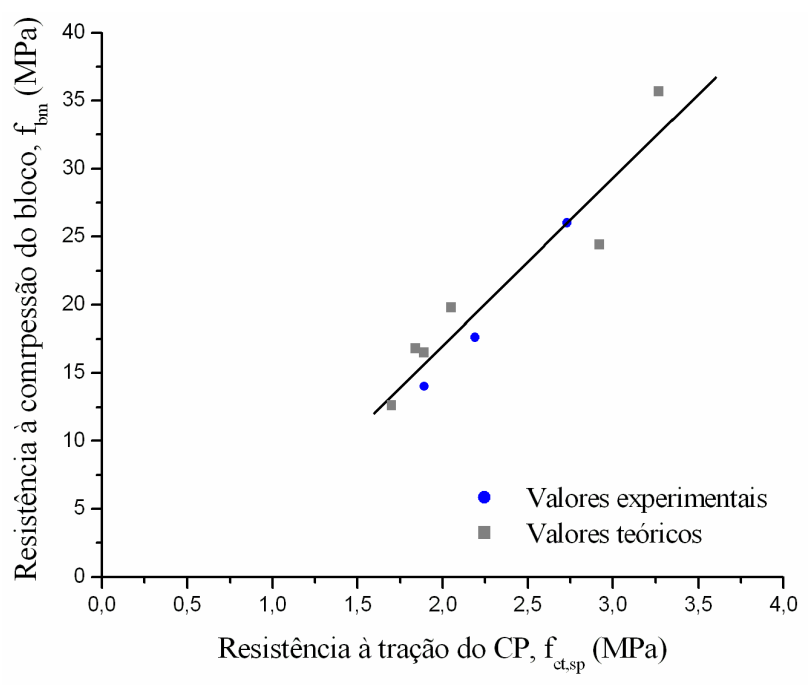

Figura 4.20 - Relação teórica e experimental entre a resistência à tração do concreto, obtida em CPs cilíndricos, e a resistência à compressão do bloco.

O Quadro 4.1 resume as diversas relações encontradas entre resistência do bloco e do corpo-de-prova. Como citado no Capítulo 2, existe grande divergência entre 
esses valores, principalmente pelas características dos ensaios, que abrangem diferentes tipos de blocos (vazados e sólidos) e distintas geometrias de corpos-de-prova.

As deformações ocorridas nas paredes dos blocos, analisando-se distintos pontos, apresentaram diferentes valores. $O$ primeiro fator que determina tal comportamento é a configuração geométrica do elemento, ocasionando distribuição não uniforme das tensões e acarretando diferentes valores de deformações. Essa diferença, contudo, não é tão significante frente aos resultados obtidos nos ensaios, o que indica que não houve deslocamento uniforme do topo do bloco. A placa disposta entre a superfície de carregamento do bloco e o atuador não foi capaz de transmitir uniformemente a força na região central e extrema dos blocos, provavelmente fletindose nas extremidades devido à condição de contorno imposta no ensaio.

As simulações numéricas, realizadas no Capítulo 5, ilustram melhor tal fenômeno.

Quadro 4.1 - Diversas pesquisas que correlacionam resistência à compressão de blocos e corpos-deprova.

\begin{tabular}{|c|c|c|c|c|}
\hline Autor & Corpo-de-prova & Dimensões & Bloco & $\begin{array}{c}\text { Relação } \\
\text { CP/Bloco }\end{array}$ \\
\hline $\begin{array}{c}\text { Becica e } \\
\text { Harris (1983) }\end{array}$ & $\begin{array}{c}\text { Prismáticos extraídos } \\
\text { do bloco }\end{array}$ & $\begin{array}{c}1: 1 \text { a } 2: 1 \\
\text { (altura:largura), } \\
\text { com a espessura } \\
\text { original }\end{array}$ & $\begin{array}{c}\text { Vazado de } \\
\text { concreto } \\
20 \times 20 \times 39 \mathrm{~cm}\end{array}$ & 1,22 \\
\hline $\begin{array}{c}\text { Frasson } \\
\text { Júnior }(2000)\end{array}$ & $\begin{array}{l}\text { Moldados com } \\
\text { concreto seco }\end{array}$ & $5 \times 10 \mathrm{~cm}$ & $\begin{array}{c}\text { Vazado de } \\
\text { concreto } \\
14 \times 19 \times 39 \mathrm{~cm}\end{array}$ & 0,80 \\
\hline \multirow{2}{*}{$\begin{array}{l}\text { Ganzerli et } \\
\text { al. (2003) }\end{array}$} & $\begin{array}{l}\text { Prismáticos extraídos } \\
\text { do topo do bloco }\end{array}$ & \multirow{2}{*}{$\begin{array}{c}1: 2: 4 \\
\text { (altura: espessura: } \\
\text { comprimento) }\end{array}$} & \multirow{2}{*}{$\begin{array}{c}\text { Vazado de } \\
\text { concreto } \\
20 \times 20 \times 39 \mathrm{~cm}\end{array}$} & 1,41 \\
\hline & $\begin{array}{c}\text { Prismáticos extraídos } \\
\text { da base do bloco }\end{array}$ & & & 1,12 \\
\hline \multirow{2}{*}{$\begin{array}{l}\text { Marzahn } \\
\text { (2003) }\end{array}$} & \multirow{2}{*}{$\begin{array}{c}\text { Cilíndricos extraídos } \\
\text { do bloco }\end{array}$} & \multirow{2}{*}{$10 \times 20 \mathrm{~cm}$} & $\begin{array}{c}\text { Maciço, silico- } \\
\text { calcário } \\
23,8 \times 24 \times 50 \mathrm{~cm}\end{array}$ & $0,61-0,66$ \\
\hline & & & $\begin{array}{l}\text { Maciço, concreto } \\
\text { auto-clavado } \\
20 \times 24 \times 50 \mathrm{~cm}\end{array}$ & $0,86-0,95$ \\
\hline \multirow{3}{*}{$\begin{array}{l}\text { Presente } \\
\text { trabalho }\end{array}$} & \multirow{3}{*}{$\begin{array}{l}\text { Moldados com } \\
\text { concreto plástico }\end{array}$} & $5 \times 10 \mathrm{~cm}$ & \multirow{3}{*}{$\begin{array}{c}\text { Concreto } \\
14 \times 19 \times 39 \mathrm{~cm}\end{array}$} & $1,13-1,31$ \\
\hline & & $10 \times 20 \mathrm{~cm}$ & & $1,03-1,16$ \\
\hline & & $15 \times 30 \mathrm{~cm}$ & & $0,92-1,03$ \\
\hline
\end{tabular}




\subsection{Prismas de dois blocos colados}

A instrumentação utilizada nos prismas de dois e três blocos é apresentada na Figura 4.21. Utilizaram-se instrumentos com bases de medida de dois valores distintos, contudo, as curvas tensão x deformação apresentaram comportamento semelhante.

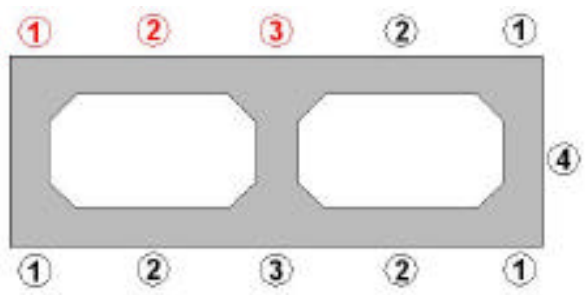

Figura 4.21 - Numeração correspondente ao posicionamento dos instrumentos de medição. Os números em vermelho indicam os instrumentos com a maior base de medida.

\subsubsection{Grupo 10}

As propriedades mecânicas obtidas em corpos-de-prova cilíndricos são apresentadas na Tabela 4.11. A Tabela 4.12 agrupa esses parâmetros, de cada ponto distinto e com numeração correspondente indicada na Figura 4.21, obtidos nos ensaios com os prismas.

Tabela 4.11 - Propriedades mecânicas dos corpos-de-prova referente aos ensaios com prismas constituído por 2 blocos - grupo 10.

\begin{tabular}{ccccc}
\hline Corpo-de-prova & $\begin{array}{c}\text { Resistência } \\
\text { média } \\
\mathrm{f}_{\mathrm{cm}}(\mathrm{MPa})\end{array}$ & $\begin{array}{c}\mathrm{f}_{\mathrm{cm}(15 \times 30)} \\
\mathrm{f}_{\mathrm{cm}}\end{array}$ & $\begin{array}{c}\text { Deformação na } \\
\text { ruptura }(\mu)\end{array}$ & $\begin{array}{c}\text { Módulo de } \\
\text { elasticidade } \\
\mathrm{E}_{\mathrm{c}}(\mathrm{MPa})\end{array}$ \\
\hline $15 \times 30$ & 14,6 & 1,00 & 5138 & 12408 \\
$10 \times 20$ & 15,9 & 0,92 & 2780 & 16874 \\
\hline
\end{tabular}

A resistência do concreto à tração é de 1,7 MPa.

Ensaiaram-se três prismas, constituídos por dois blocos de concreto, com a mesma idade dos CPs, obtendo-se as deformações ao longo da parede longitudinal e septo transversal.

As menores deformações são obtidas nos pontos 1 e 4 . Essa situação é semelhante à ocorrida nos blocos vazados de concreto, entretanto, nestes a diferença percentual entre os valores é maior. Nos prismas, a diferença entre os valores de deformação obtidos na região central e dos obtidos nos pontos 1 e 4 são menores. A deformação no ponto 3 é maior que a deformação no ponto 2 , inclusive em níveis de tensão maiores que $60 \%$ da tensão de ruína. 
Tabela 4.12 - Propriedades mecânicas do prisma constituído por 2 blocos grupo 10.

\begin{tabular}{cccc}
\hline $\begin{array}{c}\text { Resistência } \\
\text { média }\end{array}$ & Pontos & \multicolumn{2}{c}{ Deformação $(\mu)$} \\
\cline { 3 - 4 } $\mathrm{f}_{\mathrm{p} 2 \mathrm{~m}}(\mathrm{MPa})$ & & Ruína & $40 \%$ tensão máxima \\
\hline \multirow{2}{*}{13,3} & 1 & 1389 & 153 \\
& 2 & 2591 & 490 \\
& 3 & 3730 & 780 \\
& 4 & 2940 & 275 \\
\hline
\end{tabular}

As curvas tensão $\mathrm{x}$ deformação dos corpos-de-prova e dos prismas são apresentadas na Figura 4.22.

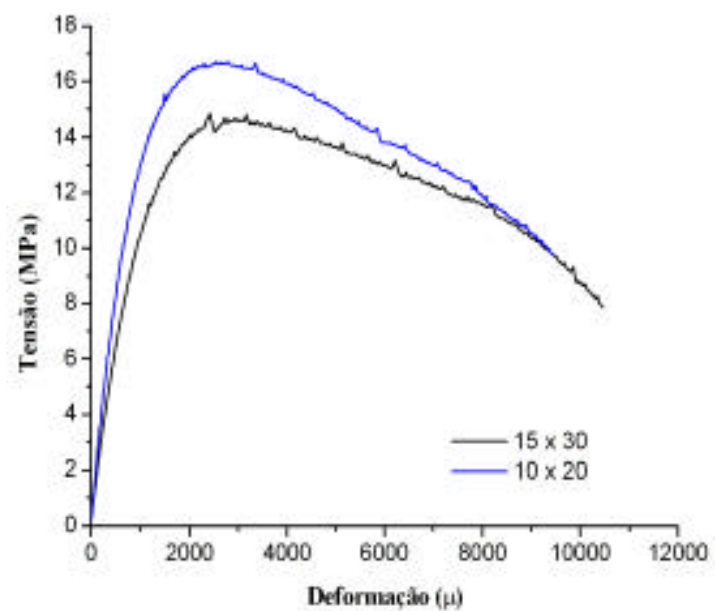

(a)

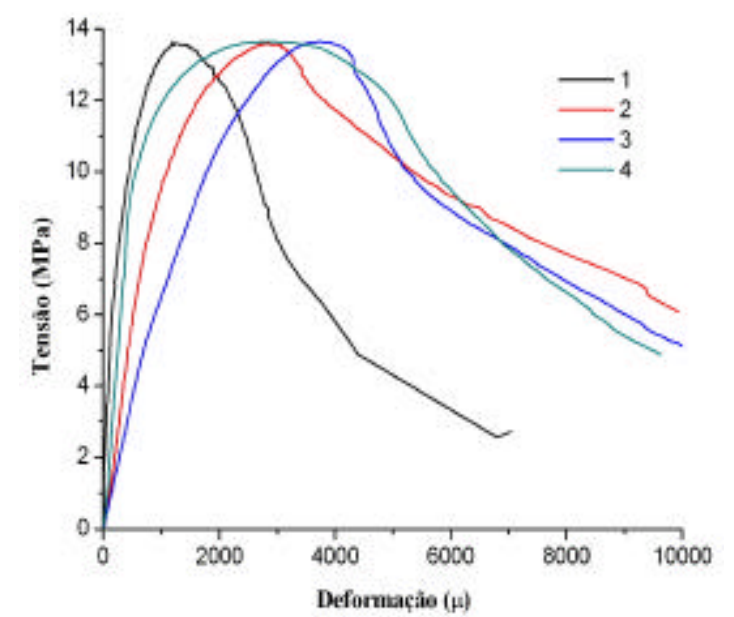

(b)

Figura 4.22 - Curvas tensão x deformação dos corpos-de-prova (a) e dos distintos pontos do prisma constituído por 2 blocos, (b) - grupo 10 .

O prisma apresenta deformação transversal a $40 \%$ da tensão máxima de ensaio de $409 \mu$, obtida a partir da curva tensão x deformação transversal apresentada na Figura 4.23a. Se comparado com os valores de deformação longitudinal obtidos no prisma no mesmo nível de tensão, obtém-se relação de 0,83 e 0,52 referentes aos pontos 2 e 3 , respectivamente.

O deslocamento transversal do bloco obtido no septo transversal, na interface do prisma, e ilustrado na Figura 4.23b, apresentou deslocamentos sob tensão máxima e a $40 \%$ dessa tensão de $0,53 \mathrm{~mm}$ e $0,06 \mathrm{~mm}$ e deformações de $3900 \mu$ e $430 \mu$, respectivamente. Este valor, referente à parede longitudinal, é próximo ao obtido por meio do gráfico da Figura 4.23a. 


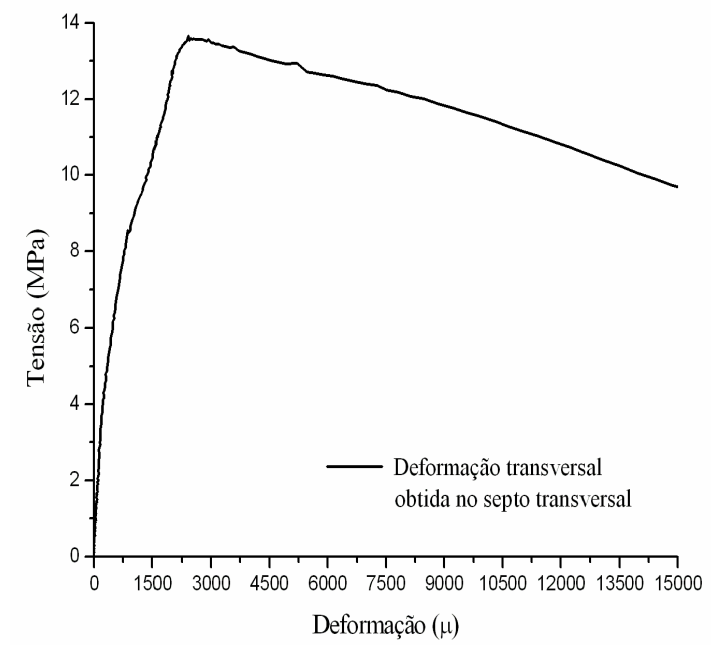

(a)

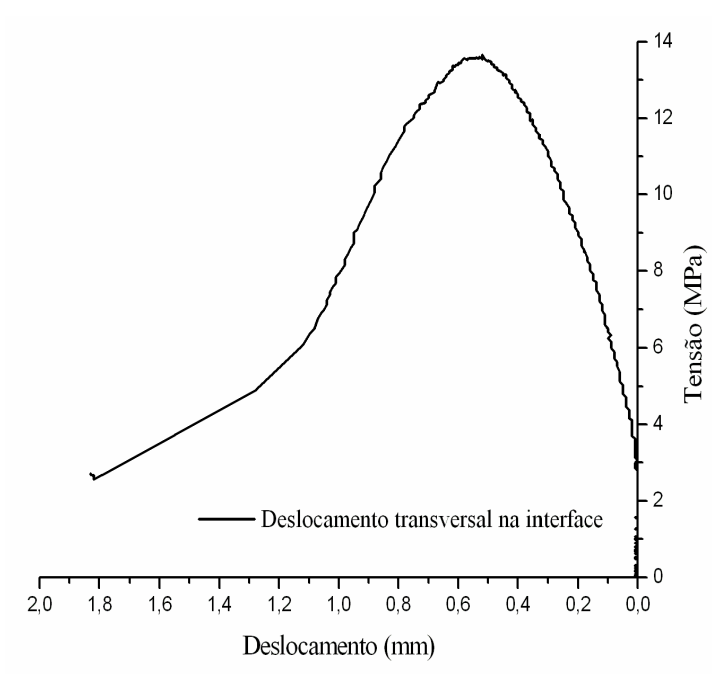

(b)

Figura 4.23 - Curva tensão x deformação transversal (a) e tensão x deslocamento na interface do $\operatorname{prisma}(b)$.

Na Figura 4.24 são apresentadas as relações entre as resistências dos elementos ensaiados. Toma-se como referência, na comparação com a resistência dos blocos, os CPs de cada grupo, já que os valores da resistência do concreto não permaneceram constantes. Ocorre aumento das relações entre a resistência à compressão dos CPs e do prisma da relação comparando-se com o grupo de ensaios de bloco 10. Um dos fatores que levam a essa diminuição de resistência do prisma de dois blocos, em relação ao bloco isolado, é o aumento da altura - por ora em duas vezes - sendo o elemento menos influenciado pelo efeito do confinamento exercido pelas placas de ensaio. Além disso, a camada de epóxi pode também interferir no comportamento do prisma, ocasionado a redução de sua resistência conforme relato de Corrêa (2003).

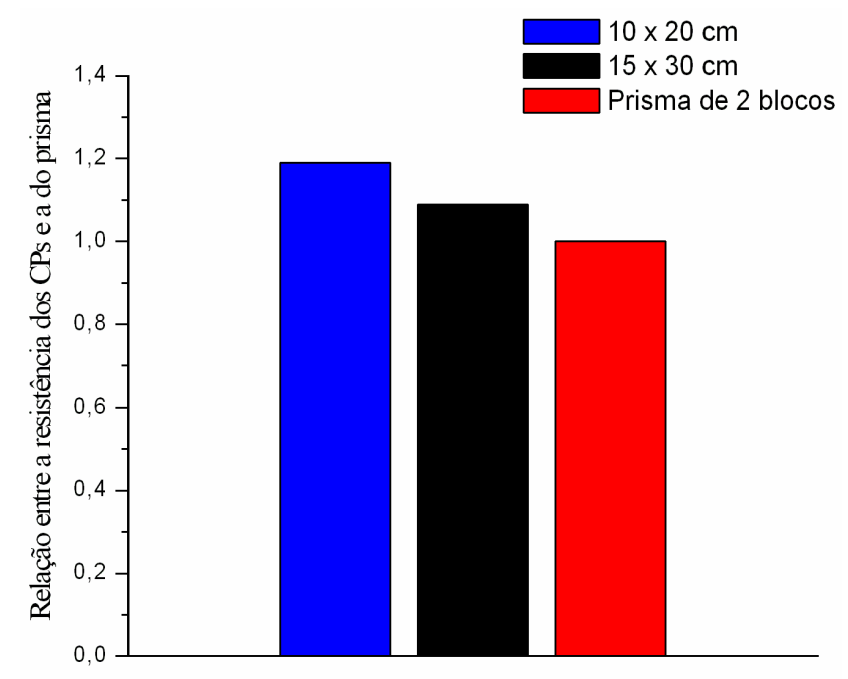

Figura 4.24 - Relação entre as resistências médias dos corpos-de-prova e prisma de dois blocos grupo 10. 
A configuração das deformações ocorridas no prisma se assemelha, até $40 \%$ da tensão máxima, com as ocorridas nos ensaios com blocos isolados, apresentando maior deformação no ponto 3 e diminuindo esses valores em direção às extremidades do bloco. Até $40 \%$ da tensão máxima o ponto 3 apresenta deformação maior $60 \%$ que a ocorrida no ponto 2. Essa relação cai com o aumento do carregamento para até $40 \%$. As deformações do ponto 4 são sempre maiores que as do ponto 1, tendo aproximadamente o dobro deste valor. A partir de $60 \%$ da tensão máxima as linhas de deformação do prisma mantêm a mesma configuração, permanecendo a região do septo transversal central com a maior deformação. As deformações obtidas nos pontos 2 e 3 são aproximadamente duas vezes maior que as dos pontos 1 e 4 . A Figura 4.25 ilustra essas deformações. Em relação aos blocos, existe uma tendência de maior uniformização das tensões ao longo da altura do elemento, acarretando uma menor diferença de tensões entre o centro e as extremidades e, conseqüentemente, menores diferenças entre os valores destas deformações.

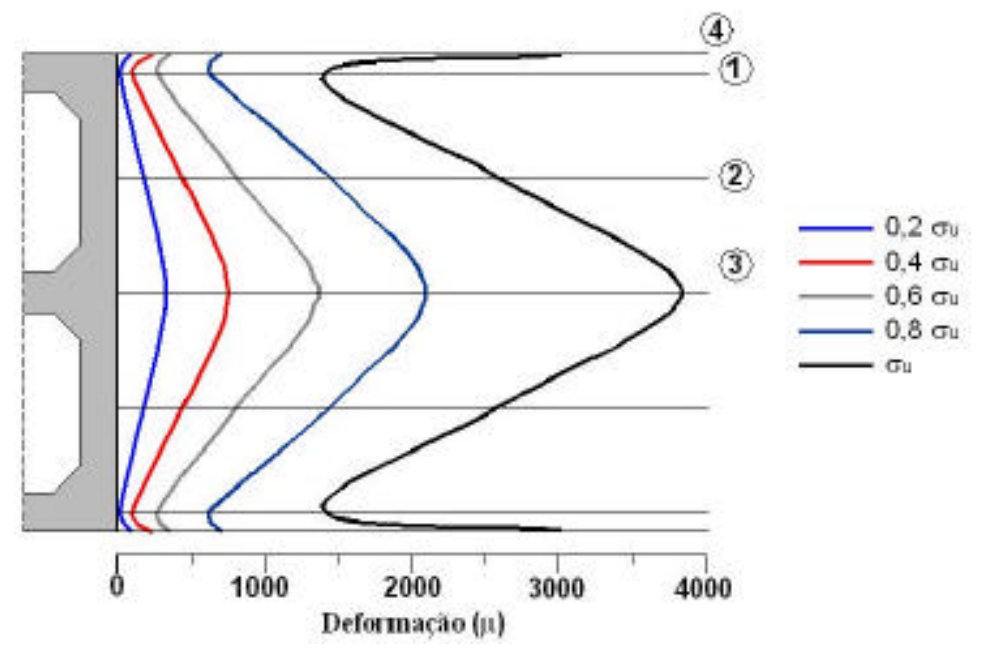

Figura 4.25 - Linhas de deformação do prisma constituído por 2 blocos - grupo 10.

\subsubsection{Grupo 20}

As propriedades dos corpos-de-prova e prismas são apresentadas na Tabela 4.13 e na Tabela 4.14 .

Baseado na resistência à compressão do corpo-de-prova 10 x $20 \mathrm{~cm}$, obtém-se para a resistência à tração do concreto o valor de $2 \mathrm{MPa}$. 
Tabela 4.13 - Propriedades mecânicas dos corpos-de-prova referente aos ensaios com prismas constituído por 2 blocos - grupo 20.

\begin{tabular}{ccccc}
\hline Corpo-de-prova & $\begin{array}{c}\text { Resistência } \\
\text { média } \\
\mathrm{f}_{\mathrm{cm}}(\mathrm{MPa})\end{array}$ & $\begin{array}{c}\mathrm{f}_{\mathrm{cm}(15 \times 30)} \\
\mathrm{f}_{\mathrm{cm}}\end{array}$ & $\begin{array}{c}\text { Deformação na } \\
\text { ruptura }(\mu)\end{array}$ & $\begin{array}{c}\text { Módulo de } \\
\text { elasticidade } \\
\mathrm{E}_{\mathrm{c}}(\mathrm{MPa})\end{array}$ \\
\hline $15 \times 30$ & 18,2 & 1,00 & 3918 & 14436 \\
$10 \times 20$ & 20,1 & 0,91 & 2852 & 16974 \\
\hline
\end{tabular}

As menores deformações são observadas nos pontos 1 e 4, enquanto que o ponto 3 apresenta maior valor de deformação que o ponto 2 .

Tabela 4.14 - Propriedades mecânicas do prisma constituído por 2 blocos grupo 20.

\begin{tabular}{cccc}
\hline $\begin{array}{c}\text { Resistência } \\
\text { média }\end{array}$ & Pontos & \multicolumn{2}{c}{ Deformação $(\mu)$} \\
\cline { 3 - 4 } $\mathrm{f}_{\mathrm{p} 2 \mathrm{~m}}(\mathrm{MPa})$ & & Ruína & $40 \%$ tensão máxima \\
\hline \multirow{2}{*}{18,2} & 1 & 1313 & 179 \\
& 2 & 3072 & 585 \\
& 3 & 4202 & 912 \\
& 4 & 1214 & 252 \\
\hline
\end{tabular}

Na Figura 4.26 apresentam-se as curvas tensão $\mathrm{x}$ deformação obtidas nos ensaios com os CPs e prismas. As curvas tensão x deformação transversal e tensão $\mathrm{x}$ deslocamento transversal na região de interface na maioria das vezes apresentam comportamento não condizente com o ensaio, sendo sempre omitidas.

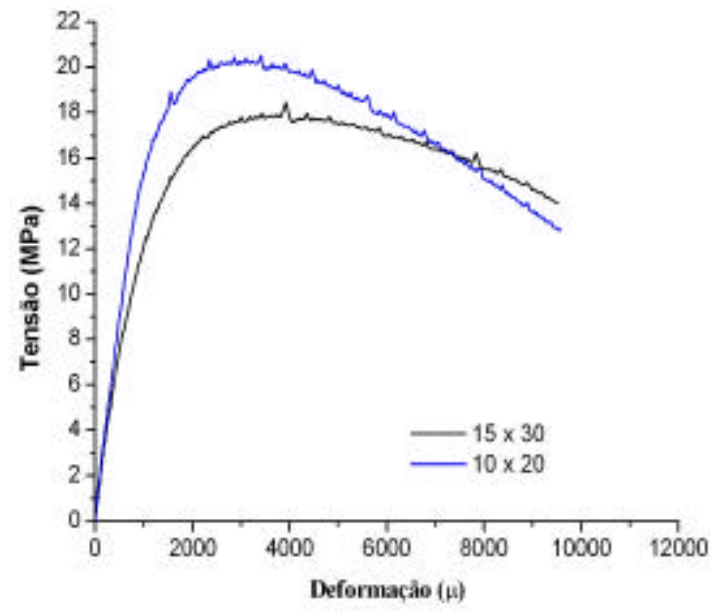

(a)

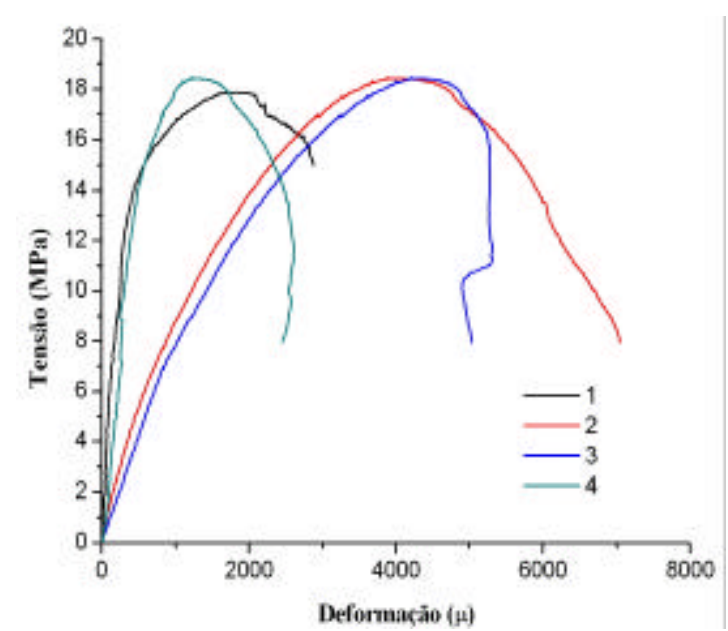

(b)

Figura 4.26 - Curvas tensão x deformação dos corpos-de-prova (a) e dos distintos pontos do prisma constituído por 2 blocos. (b) - grupo 20. 
De acordo com a Figura 4.27, as relações entre a resistência do prisma e dos CPs diminuiu. Ainda assim, essa relação permanece menor que as obtidas nos ensaios de blocos isolados, tendo os fatores descritos na análise do grupo 10 como justificativa.

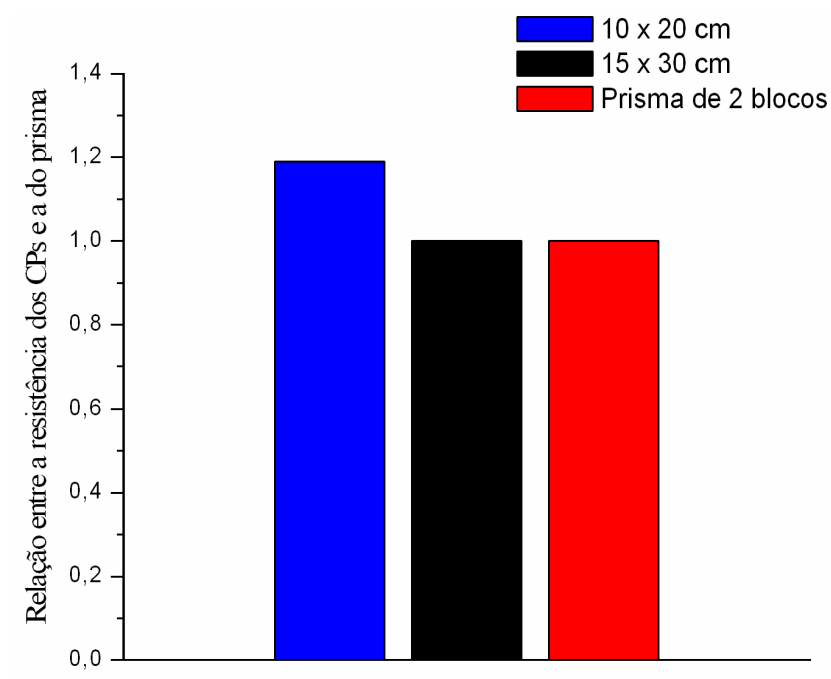

Figura 4.27 - Relação entre as resistências médias dos corpos-de-prova e prisma de dois blocos grupo 20.

De acordo coma a Figura 4.28, as linhas de deformação ao longo do bloco e nos diversos níveis de tensão mantêm a mesma configuração dos prismas do grupo 10 . A diferença dos valores de deformação entre os pontos 2 e 3 mantém o mesmo nível, sendo essas diferenças diminuídas com o aumento da tensão. As deformações no ponto 4 são maiores que as deformações no ponto 1 até $60 \%$ da tensão máxima. As diferenças entre os pontos centrais e os pontos 1 e 4 são equivalentes às encontradas para os prismas do grupo 10. A partir de $60 \%$ da tensão, evidencia-se a maior deformação no ponto 3. Os pontos 1 e 4 apresentam deformações 4 vezes menores que as encontradas na região central do bloco. 


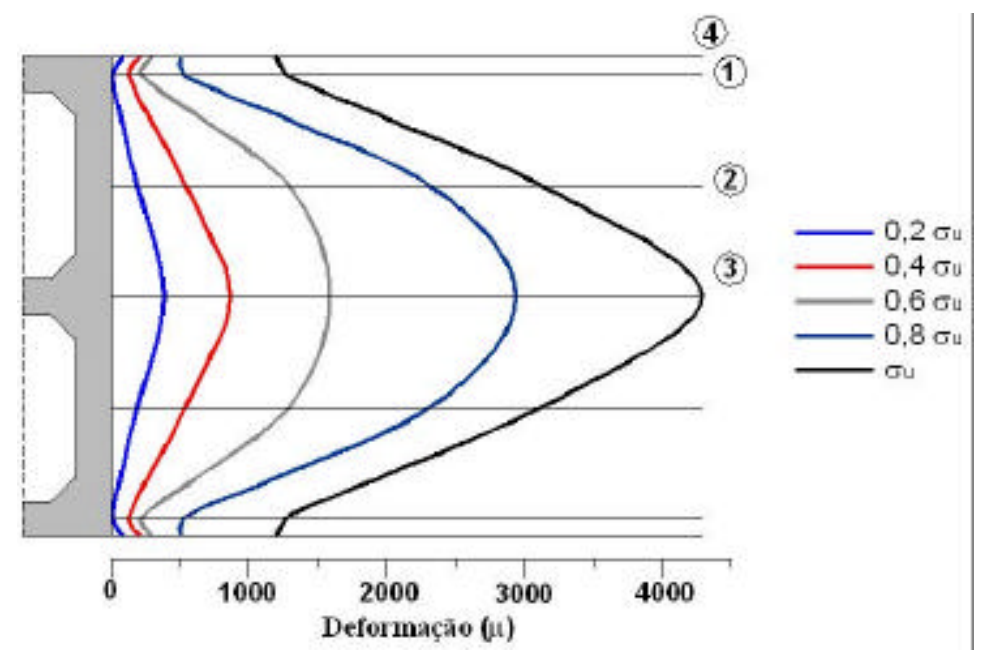

Figura 4.28 - Linhas de deformação do prisma constituído por 2 blocos - grupo 20.

\subsubsection{Grupo 30}

As propriedades obtidas nos ensaios com corpos-de-prova são apresentadas na Tabela 4.15. A resistência à tração do concreto é de $3 \mathrm{MPa}$. Os ensaios realizados paralelamente com os prismas têm suas propriedades mecânicas apresentadas na Tabela 4.16.

Tabela 4.15 - Propriedades mecânicas dos corpos-de-prova referente aos ensaios com prismas constituído por 2 blocos - grupo 30.

\begin{tabular}{ccccc}
\hline Corpo-de-prova & $\begin{array}{c}\text { Resistência } \\
\text { média } \\
\mathrm{f}_{\mathrm{cm}}(\mathrm{MPa})\end{array}$ & $\begin{array}{c}\mathrm{f}_{\mathrm{cm}(15 \times 30)} \\
\mathrm{f}_{\mathrm{cm}}\end{array}$ & $\begin{array}{c}\text { Deformação na } \\
\text { ruptura }(\mu)\end{array}$ & $\begin{array}{c}\text { Módulo de } \\
\text { elasticidade } \\
\mathrm{E}_{\mathrm{c}}(\mathrm{MPa})\end{array}$ \\
\hline $15 \times 30$ & 32,3 & 1,00 & 2933 & 19671 \\
$10 \times 20$ & 37,1 & 0,87 & 2636 & 24961 \\
\hline
\end{tabular}

As menores deformações, até $40 \%$ da tensão máxima, ocorreram nos pontos 1 e 4. Não foi possível, por meio dos dados disponíveis, a obtenção do valor da deformação última referente ao ponto 1. Em relação aos grupos 10 e 20, os pontos centrais apresentaram valores de deformação menores, em conseqüência do aumento do módulo de elasticidade do concreto utilizado nos blocos. Em contrapartida, os valores das deformações nos pontos 1 e 4 aumentaram. 
Tabela 4.16 - Propriedades mecânicas do prisma constituído por 2 blocos grupo 30.

\begin{tabular}{cccc}
\hline $\begin{array}{c}\text { Resistência } \\
\text { média } \\
\mathrm{f}_{\mathrm{p} 2 \mathrm{~m}(\mathrm{MPa})}\end{array}$ & Pontos & Ruína & 40\% tensão máxima \\
\cline { 3 - 4 } & 1 & - & 227 \\
26,3 & 2 & 3504 & 534 \\
& 3 & 2674 & 699 \\
& 4 & 646 & 541 \\
\hline T36\% da tensão máxima. & & &
\end{tabular}

Na Figura 4.29 são apresentados os gráficos das curvas tensão x deformação dos CPs e prismas.

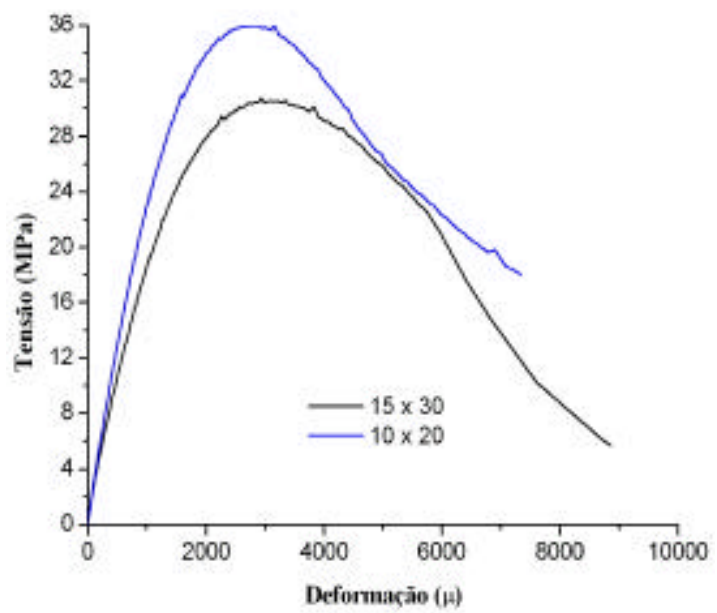

(a)

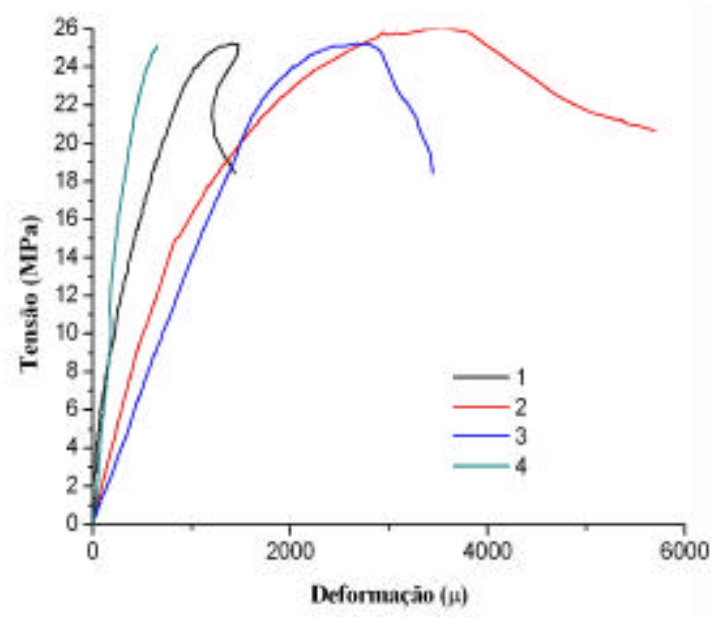

(b)

Figura 4.29 - Curvas tensão x deformação dos corpos-de-prova (a) e dos distintos pontos do prisma (b) - grupo 30.

O valor da relação entre a resistência do prisma e a dos CPs é maior que as obtidas nos ensaios dos os grupos 10 e 20. O menor valor da resistência do prisma em relação às resistências dos CPs, apresentados na Figura 4.30, segue a tendência apresentada nos grupos 10 e 20. 


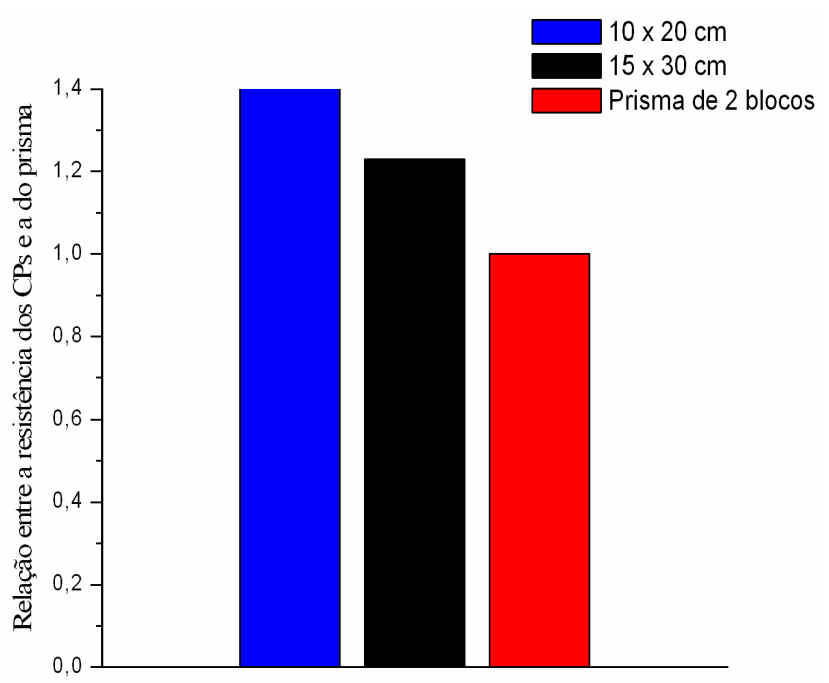

Figura 4.30 - Relação entre as resistências médias dos corpos-de-prova e prisma de dois blocos grupo 30.

A Figura 4.31 ilustra as linhas de deformação do prisma. A diferença em relação aos ensaios dos dois grupos anteriores é que ao nível de $80 \%$ da tensão máxima o ponto 3 apresenta menor deformação que o ponto 2, provavelmente devido a alguma perturbação no ensaio. Nesse exemplo, o ponto 4 apresenta menores deformações que o ponto 3. Contudo, as deformações na extremidade do bloco mantêm-se aproximadamente 3 vezes menores que as ocorridas na região central.

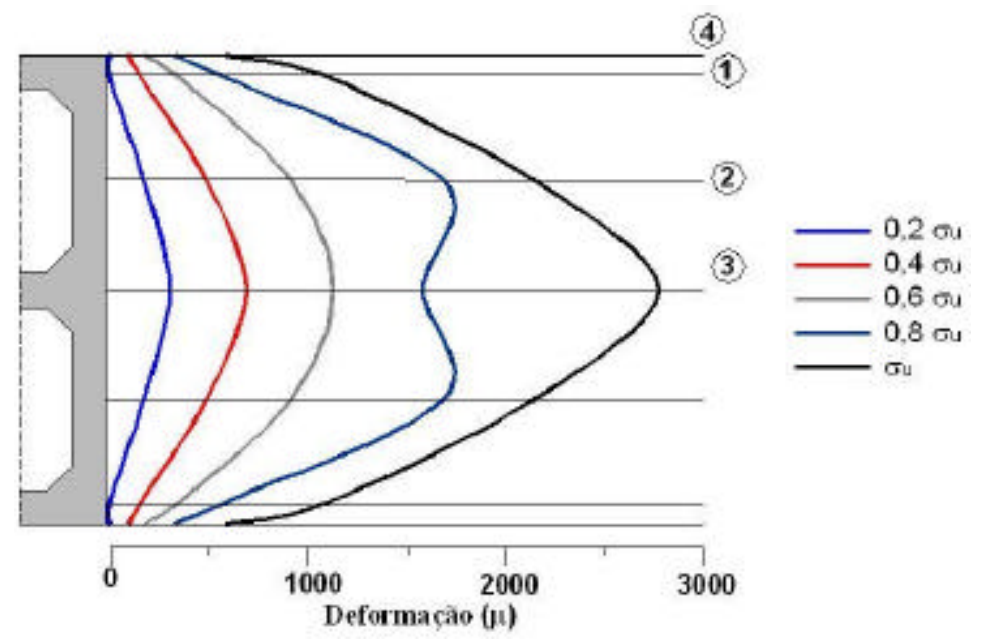

Figura 4.31 - Linhas de deformação do prisma constituído por 2 blocos - grupo 30.

\subsection{Prismas de 3 blocos colados}

A Figura 4.21 refere-se à numeração da instrumentação dos prismas constituídos por três blocos. Da mesma forma que o sucedido com os prismas de dois blocos, as curvas tensão x deformação obtidas com instrumentos de bases de medida 
distintas foram análogas. Realizam-se análises semelhantes às efetuadas com os prismas de dois blocos.

\subsubsection{Grupo 10}

Os resultados dos ensaios de corpos-de-prova e prismas constituídos por 3 blocos estão agrupados na Tabela 4.17 e na Tabela 4.18 .

Tabela 4.17 - Propriedades mecânicas dos corpos-de-prova referente aos ensaios com prismas constituí do por 3 blocos - grupo 10.

\begin{tabular}{ccccc}
\hline Corpo-de-prova & $\begin{array}{c}\text { Resistência } \\
\text { média } \\
\mathrm{f}_{\mathrm{cm}}(\mathrm{MPa})\end{array}$ & $\begin{array}{c}\mathrm{f}_{\mathrm{cm}(15 \times 30)} \\
\mathrm{f}_{\mathrm{cm}}\end{array}$ & $\begin{array}{c}\text { Deformação na } \\
\text { ruptura }(\mu)\end{array}$ & $\begin{array}{c}\text { Módulo de } \\
\text { elasticidade } \\
\mathrm{E}_{\mathrm{c}}(\mathrm{MPa})\end{array}$ \\
\hline $15 \times 30$ & 12,3 & 1,00 & 3057 & 12107 \\
$10 \times 20$ & 13,7 & 0,90 & 2225 & 17424 \\
\hline
\end{tabular}

O valor da resistência à tração do concreto é de 1,6 MPa.

As deformações obtidas nos pontos 2 e 3 permanecem maiores que as obtidas nos pontos 1 e 4, entretanto, a diferença entre esses valores é menor. Ocorre também aumento - em relação aos ensaios com blocos isolados e prismas constituídos por dois blocos - do valor numérico da deformação nos pontos 1 e 4, caracterizando uma redistribuição das tensões devido à maior altura do elemento.

Tabela 4.18 - Propriedades mecânicas do prisma constituído por 3 blocos grupo 10.

\begin{tabular}{cccc}
\hline $\begin{array}{c}\text { Resistência } \\
\text { média }\end{array}$ & Pontos & \multicolumn{2}{c}{ Deformação $(\mu)$} \\
\cline { 3 - 4 } $\mathrm{f}_{\mathrm{p} 3 \mathrm{~m}}(\mathrm{MPa})$ & & Ruína & $40 \%$ tensão máxima \\
\hline \multirow{2}{*}{7,9} & 1 & 1694 & 226 \\
& 2 & 2315 & 408 \\
& 3 & 2995 & 616 \\
& 4 & - & 392 \\
\hline
\end{tabular}

As curvas tensão x deformação dos corpos-de-prova e dos prismas, referentes aos distintos pontos de medição, são apresentadas na Figura 4.32. Nos ensaios com prismas de três blocos não se obtiveram curvas tensão x deformação transversal que representassem adequadamente os ensaios à compressão axial. 


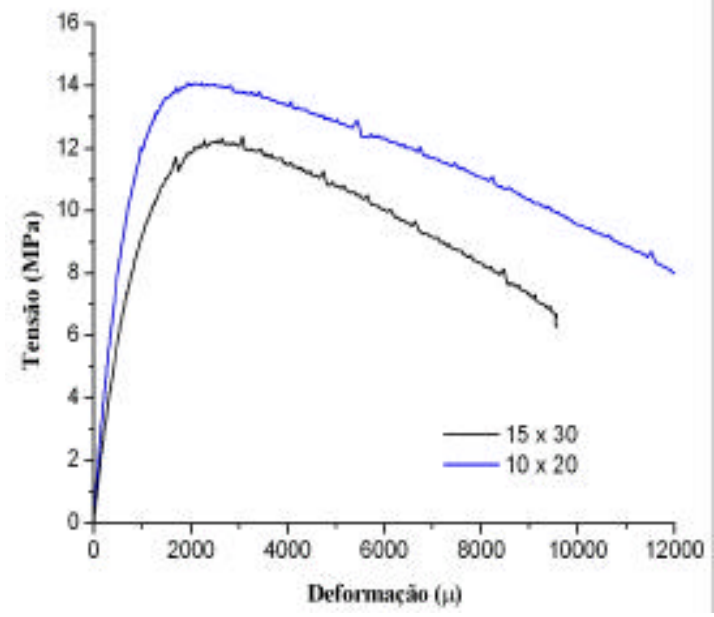

(a)

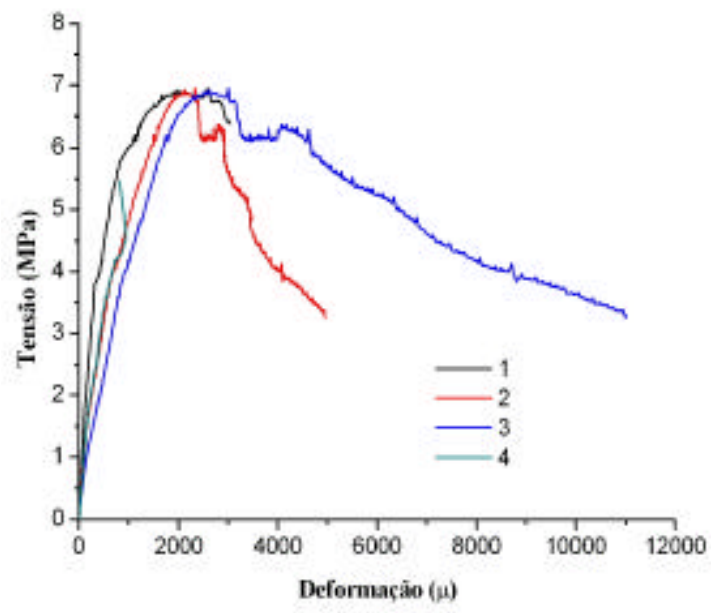

(b)

Figura 4.32 - Curvas tensão x deformação dos corpos-de-prova (a) e dos distintos pontos do prisma constituído por 3 blocos (b) - grupo 10.

A Figura 4.33 apresenta as relações entre a resistência dos CPs e a resistência dos prismas de três blocos. Esses valores são maiores que os obtidos nos ensaios com blocos isolados e prismas de dois blocos. Com o aumento da altura do prisma, que é 3 vezes maior que um bloco isolado e 1,5 vezes maior que o prisma constituído por dois blocos, ocorre o decréscimo do valor da resistência desse elemento. A disposição dos elementos que constituem o prisma - bloco e adesivo estrutural - também pode influenciar o decréscimo dos valores.

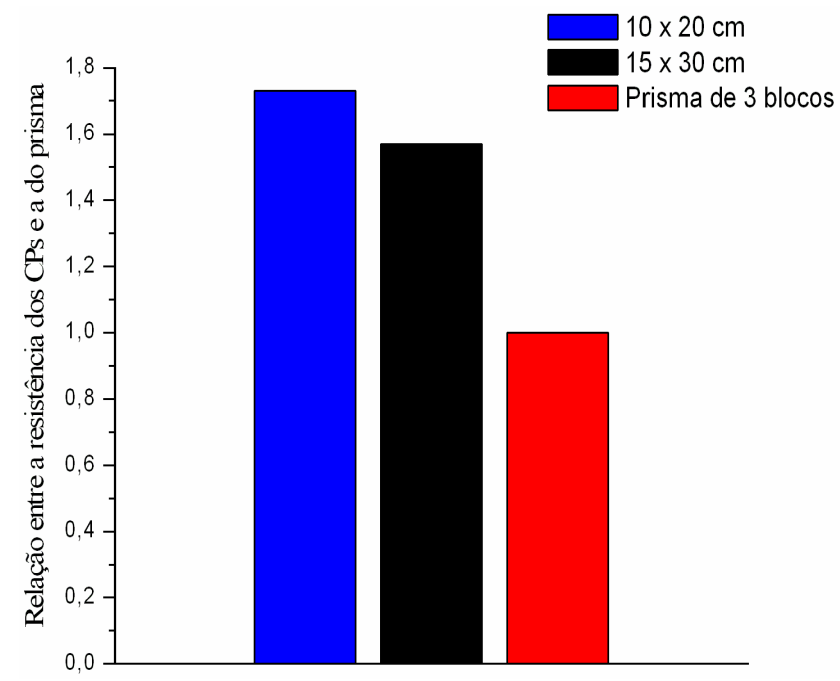

Figura 4.33 - Relação entre as resistências médias dos corpos-de-prova e prisma de três blocos grupo 10.

As linhas de deformação dos prismas de três blocos são apresentadas na Figura 4.34. As maiores deformações em todos os níveis de tensão ocorrem no ponto 3, que apresenta valores $70 \%$ maiores que no ponto 2 . O ponto 4 apresenta maiores deformações que o ponto 1; as deformações dos pontos mais extremos do bloco, 
comparando-se com os prismas de dois blocos, se aproximam mais das deformações obtidas nos pontos centrais. Com o aumento do nível de tensão a diferença entre os valores de deformação tende a diminuir.

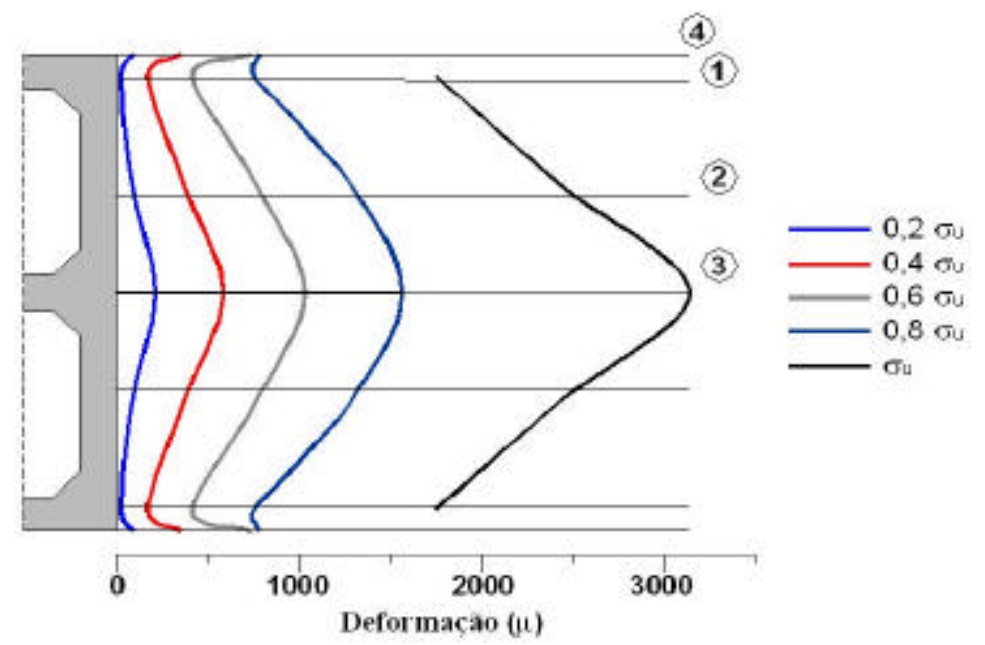

Figura 4.34 - Linhas de deformação do prisma constituído por 3 blocos - grupo 10.

\subsubsection{Grupo 20}

Os dados apresentados na Tabela 4.19 referem-se aos ensaios de corpos-deprova.

Tabela 4.19 - Propriedades mecânicas dos corpos-de-prova referente aos ensaios com prismas constituído por 3 blocos - grupo 20.

\begin{tabular}{ccccc}
\hline Corpo-de-prova & $\begin{array}{c}\text { Resistência } \\
\text { média } \\
\mathrm{f}_{\mathrm{cm}}(\mathrm{MPa})\end{array}$ & $\begin{array}{c}\mathrm{f}_{\mathrm{cm}(15 \times 30)} \\
\mathrm{f}_{\mathrm{cm}}\end{array}$ & $\begin{array}{c}\text { Deformação na } \\
\text { ruptura }(\mu)\end{array}$ & $\begin{array}{c}\text { Módulo de } \\
\text { elasticidade } \\
\mathrm{E}_{\mathrm{c}}(\mathrm{MPa})\end{array}$ \\
\hline $15 \times 30$ & 17,5 & 1,00 & 2447 & 12889 \\
$10 \times 20$ & 20 & 0,88 & 1951 & 20861 \\
\hline
\end{tabular}

$\mathrm{f}_{\mathrm{ct}, \mathrm{sp}}$ é igual a $2 \mathrm{MPa}$.

As deformações são semelhantes às obtidas nos ensaios com os prismas do grupo 10, inclusive apresentando valores numéricos de deformações bem próximos. A Tabela 4.20 apresenta os resultados obtidos nos ensaios com prismas constituídos por três blocos. 
Tabela 4.20 - Propriedades mecânicas do prisma constituído por 3 blocos grupo 20.

\begin{tabular}{cccc}
\hline $\begin{array}{c}\text { Resistência } \\
\text { média }\end{array}$ & Pontos & \multicolumn{2}{c}{ Deformação $(\mu)$} \\
\cline { 3 - 4 } $\mathrm{f}_{\mathrm{p} 3 \mathrm{~m}}(\mathrm{MPa})$ & & Ruína & $40 \%$ tensão máxima \\
\hline \multirow{2}{*}{14,4} & 1 & 1515 & 220 \\
& 2 & 2356 & 426 \\
& 3 & 3217 & 615 \\
& 4 & 863 & 349 \\
\hline
\end{tabular}

As curvas tensão x deformação dos CPs e prismas estão apresentadas na Figura 4.35 .

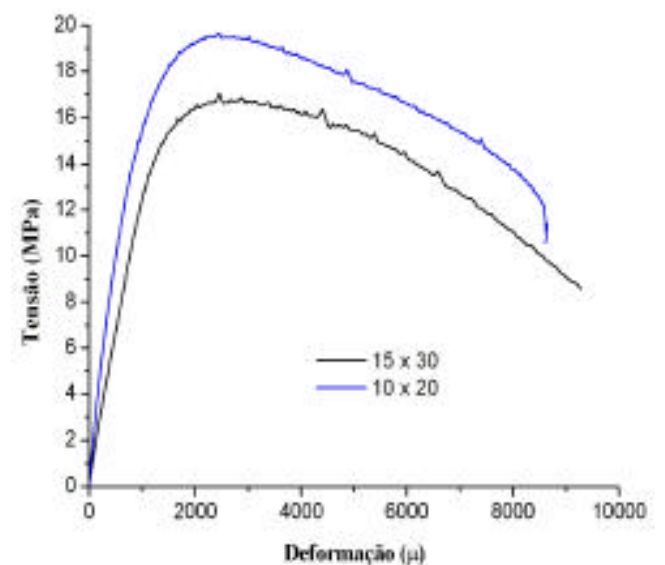

(a)

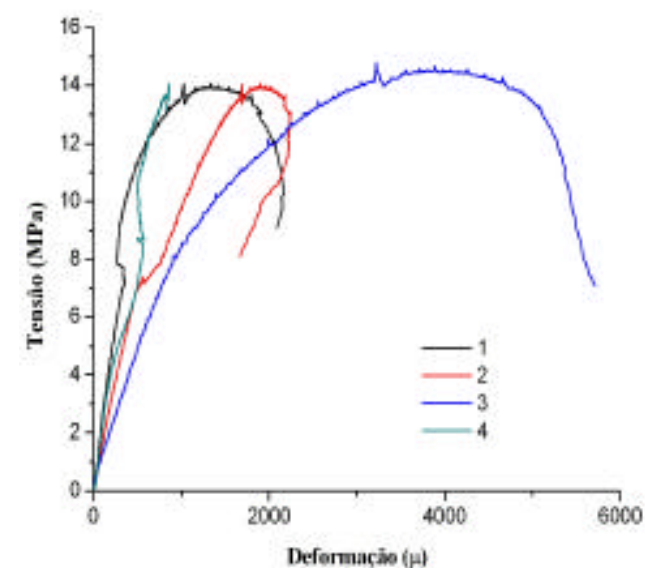

(b)

Figura 4.35 - Curvas tensão x deformação dos corpos-de-prova (a) e dos distintos pontos do prisma constituído por 3 blocos (b) - grupo 20.

A relação entre as resistências dos CPs e do prisma diminuiu em relação ao grupo 10, fato justificado pela baixa resistência que estes prismas apresentaram em decorrência das imperfeições ocorridas em sua construção. Todavia, em relação aos CPs e aos prismas de dois blocos do grupo 20 essa relação é menor. As correlações são apresentadas na Figura 4.36. 


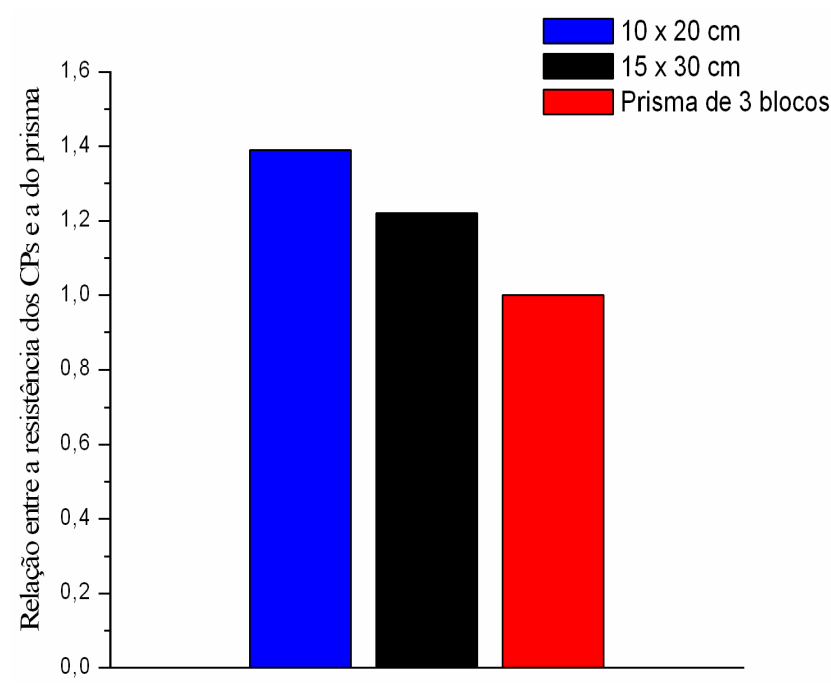

Figura 4.36 - Relação entre as resistências médias dos corpos-de-prova e prisma de três blocos grupo 20.

As linhas de deformação do prisma apresentam configuração diferente da obtida no prisma do grupo 10 e da obtida nos ensaios com prisma de dois blocos. A construção dos elementos e/ou problemas na aquisição de dados podem ter causado essas diferenças. Como ilustra a Figura 4.37, a diferença de deformação entre os pontos 2 e 3 é bem perceptível a partir de $20 \%$ da tensão máxima, tendo o ponto 3 valores de deformação maiores $100 \%$ que os obtidos no ponto 2 . Isso acarreta o aparecimento de "picos" nas linhas de deformação e, conseqüentemente, aumento na diferença das deformações na região central nas extremidades do prisma. O ponto 4 apresenta as menores deformações.

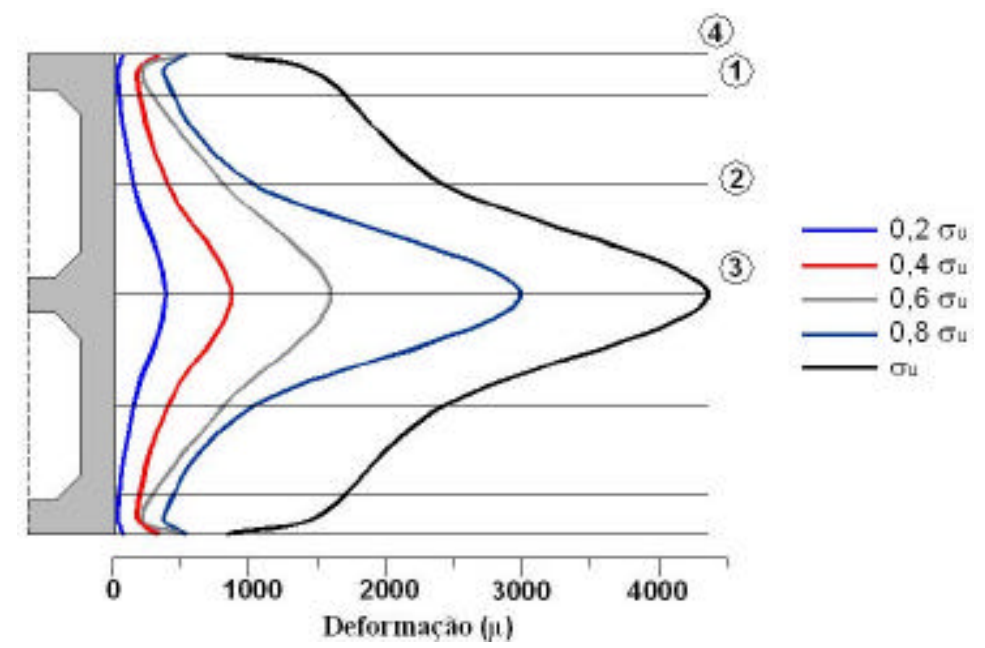

Figura 4.37 - Linhas de deformação do prisma constituído por 3 blocos - grupo 20. 


\subsubsection{Grupo 30}

Os dados apresentados na Tabela 4.21 e na Tabela 4.22 referem-se, respectivamente, aos ensaios de CPs e prismas. $\mathrm{O} \mathrm{f}_{\mathrm{ct}, \mathrm{sp}}$ vale 2,9 $\mathrm{MPa}$.

Tabela 4.21 - Propriedades mecânicas dos corpos-de-prova referente aos ensaios com prismas constituído por 3 blocos - grupo 30.

\begin{tabular}{ccccc}
\hline Corpo-de-prova & $\begin{array}{c}\text { Resistência } \\
\text { média } \\
\mathrm{f}_{\mathrm{cm}}(\mathrm{MPa})\end{array}$ & $\begin{array}{c}\mathrm{f}_{\mathrm{cm}(15 \times 30)} \\
\mathrm{f}_{\mathrm{cm}}\end{array}$ & $\begin{array}{c}\text { Deformação na } \\
\text { ruptura }(\mu)\end{array}$ & $\begin{array}{c}\text { Módulo de } \\
\text { elasticidade } \\
\mathrm{E}_{\mathrm{c}}(\mathrm{MPa})\end{array}$ \\
\hline $15 \times 30$ & 31,9 & 1,00 & 3278 & 18959 \\
$10 \times 20$ & 34,1 & 0,94 & 2509 & 25770 \\
\hline
\end{tabular}

Apesar dos valores das deformações permanecerem no mesmo nível dos obtidos nos ensaios do grupo 10 e 20, os valores das deformações nos pontos 1 e 4 apresentaram são menores.

As curvas tensão $\mathrm{x}$ deformação dos CPs e do prisma são apresentadas na Figura 4.38.

Tabela 4.22 - Propriedades mecânicas do prisma constituído por 3 blocos colados - grupo 30 .

\begin{tabular}{cccc}
\hline $\begin{array}{c}\text { Resistência } \\
\text { média }\end{array}$ & Pontos & Ruína & 40\% tensão máxima \\
\cline { 3 - 4 } $\mathrm{f}_{\mathrm{p} 3 \mathrm{~m}}(\mathrm{MPa})$ & & 959 & 188 \\
& 1 & 1041 & 432 \\
20,2 & 2 & 2086 & 646 \\
& 3 & - & 81 \\
\hline
\end{tabular}

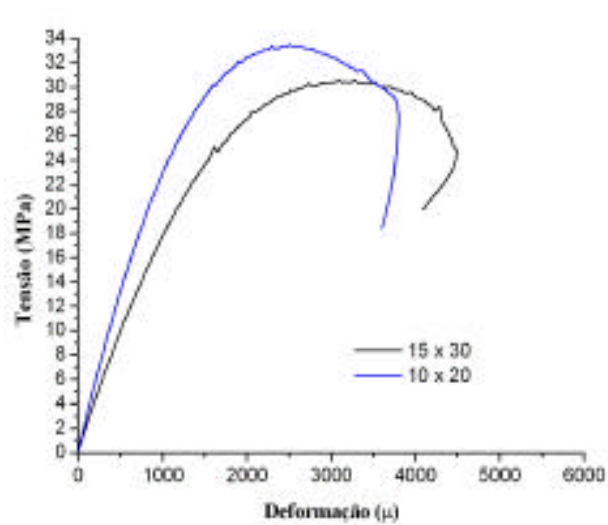

(a)

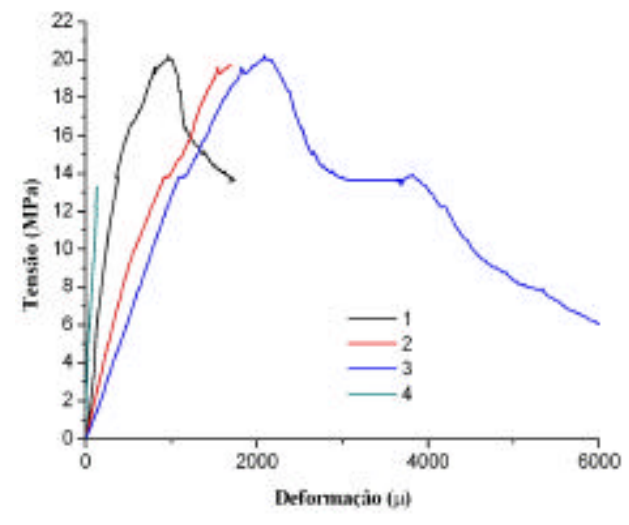

(b)

Figura 4.38 - Curvas tensão x deformação dos corpos-de-prova (a) e dos distintos pontos do prisma constituído por 3 blocos (b) - grupo 30 . 
Na Figura 4.39 apresentam-se as correlações entre as resistências dos CPs e do prisma, que possuem valor mais alto que os obtidos nos ensaios com blocos isolados e prismas de dois blocos.

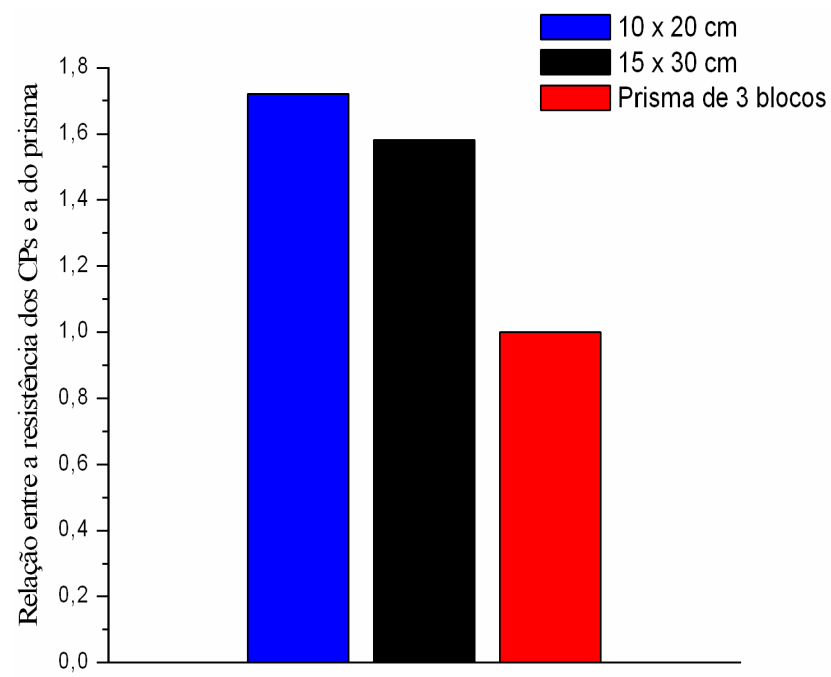

Figura 4.39 - Relação entre as resistências médias dos corpos-de-prova e prisma de três blocos grupo 30.

Diferente da configuração do grupo 20, as linhas do grupo 30 não apresentam "picos" de deformação, permanecendo a evidência de uma maior valor no ponto 3 , visualizada em todas as linhas de deformação da Figura 4.40. O ponto 3 apresenta deformações em torno de 1,5 vezes maiores que as obtidas no ponto 2 . O ponto 4 , ao contrário do comportamento dos dois grupos anteriores, apresenta menores deformações que o ponto 2 .

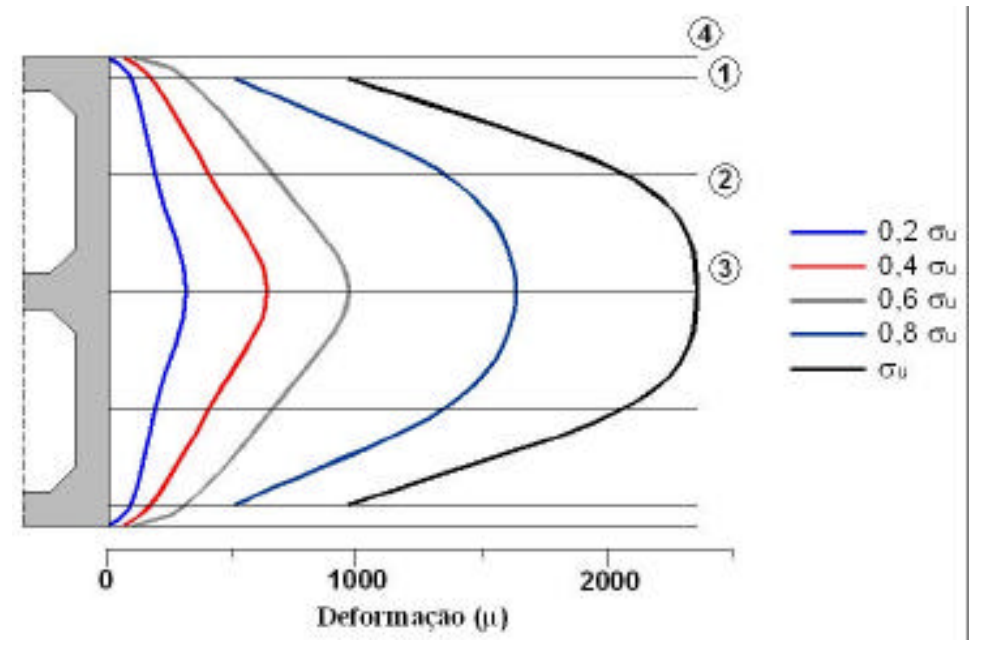

Figura 4.40 - Linhas de deformação do prisma constituído por 3 blocos - grupo 30. 


\subsection{Resistência e deformabilidade dos prismas}

A Figura 4.41 apresenta três curvas que mostram a tendência de correlação entre a resistência à compressão do concreto e a resistência à compressão dos elementos moldados com esse material.

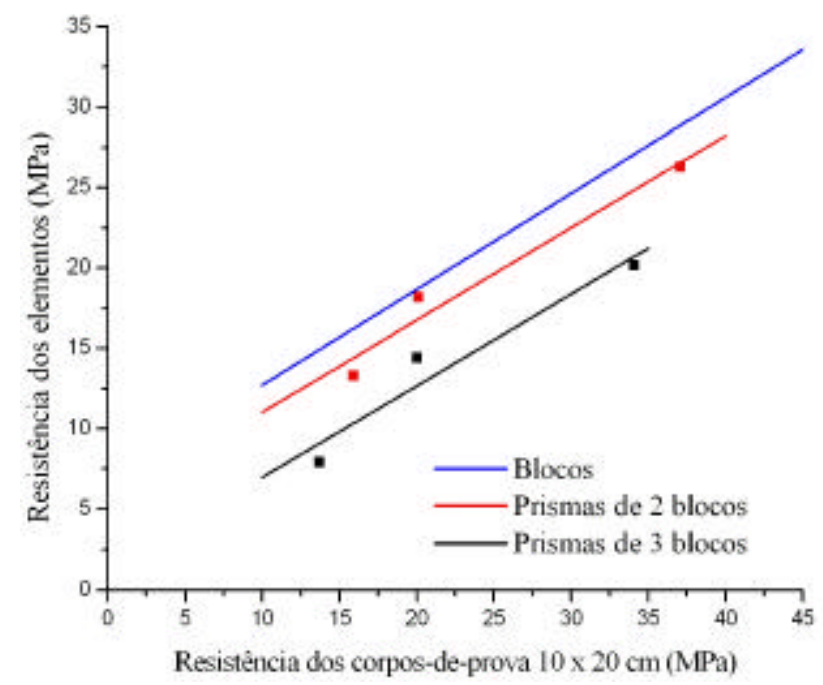

Figura 4.41 - Curvas de tendência da relação entre a resistência à compressão em corpos-deprova cilíndricos com blocos e prismas.

Os prismas de três blocos apresentam resistência inferior aos prismas de dois blocos e aos blocos isolados.

As retas apresentam inclinações semelhantes, $35^{\circ}$ na reta dos blocos e $30^{\circ}$ na reta dos prismas, expondo uma propensão de correlação análoga entre a resistência à compressão do concreto e dos elementos de diversas alturas. A relação de resistência entre o prisma de dois e três blocos e o corpo-de-prova do grupo 20 distancia-se da reta de tendência, entretanto, correlações mais precisas só são possíveis de obter com a realização de um maior número de ensaios.

Analisado os valores das deformações nos diversos pontos dos blocos e prismas, nota-se que a altura dos elementos leva a uma melhor distribuição da tensão, apresentando os pontos centrais ( 2 e 3 ) menores valores de deformações nos elementos com maior altura. A redução desses valores leva ao aumento nos pontos mais extremos $(1 \mathrm{e} 4)$

Contudo, ainda é considerável a influência da deformação da placa de ensaio nas deformações ao longo das paredes dos prismas, ainda que minimizada pela diferença de altura dos elementos, obtendo-se menores diferenças dos valores de deformações nos pontos centrais e extremos. 


\section{ANÁLISE TEÓRICA E CONFRONTAÇÃO DE RESULTADOS}

As análises teóricas são baseadas em simulações numéricas fundamentadas no Método dos Elementos Finitos e em comparações entre as propriedades mecânicas obtidas nos ensaios com blocos e corpos-de-prova.

Nas análises numéricas caracteriza-se a distribuição de tensões e deformações nos ensaios de blocos, comparando os resultados obtidos em duas condições distintas de ensaio.

Apresenta-se uma forma peculiar de avaliar a resistência e a deformabilidade dos blocos vazados de concreto a partir das propriedades mecânicas do concreto, obtidas em ensaios com corpos-de-prova.

\subsection{Análises numéricas}

Utiliza-se nessas análises o programa ANSYS 5.5, fundamentado no Método dos Elementos Finitos. O MEF é uma ferramenta bastante útil para determinar o comportamento das estruturas, realizando previsões antecipadas do comportamento delas por intermédio da determinação de tensões no componente. Contudo, para se ter um modelo próximo do real, alguns pré-requisitos devem ser dominados:

- Entendimento do problema físico a ser simulado;

- Conhecimento do comportamento estrutural a ser desejado;

- Conhecimento das propriedades dos materiais envolvidos;

- Definição das condições de contorno - cargas e vínculos da estrutura.

Objetiva-se com a análise numérica, aprofundar o conhecimento do comportamento de blocos e prismas quando submetidos à compressão axial, justificando, posteriormente, alguns resultados obtidos nas análises experimentais. 
Comparam-se dois modelos representativos dos ensaios com blocos, um com o bloco submetido a um deslocamento uniforme do topo, e o outro, com a aplicação do carregamento sobre uma placa de aço em uma área similar à das análises experimentais. Detalha-se a distribuição de tensões nesses dois modelos.

Analisa-se a distribuição de tensões em um bloco de maior altura $(57 \mathrm{~cm})$, correspondente ao prisma de três blocos colados, submetido a um carregamento na região central da placa.

As simulações numéricas são limitadas ao comportamento no regime elástico linear.

\subsubsection{Discretização da malha e propriedades mecânicas dos materiais}

Nas modelagens, utiliza-se o elemento tridimensional Solid Concrete 65. De acordo com o Ansys Release 5.5 (1999), esses elementos são utilizados em estruturas sólidas com ou sem reforço, sendo capaz de fissurar, quando solicitado à tração, ou de esmagar, quando solicitado à compressão. Enfatiza-se que um aspecto importante desse elemento é a possibilidade do tratamento não-linear dado às propriedades do material, sendo o concreto capaz de fissurar (nas três direções ortogonais), de esmagar, de se deformar plasticamente e de sofrer o efeito da fluência. O elemento é definido por 8 nós - cada um com três graus de liberdade: translações nodais $\mathrm{x}, \mathrm{y}$ e $\mathrm{z}$ - e propriedades isotrópicas do material. A geometria, a localização dos nós e o sistema de coordenadas para esse elemento são apresentados na Figura 5.1. As tensões podem ser introduzidas como forças de superfície nas faces do elemento. A direção da tensão no elemento é paralela ao sistema de coordenada do elemento. Para soluções não-lineares devem ser especificadas as referidas propriedades.

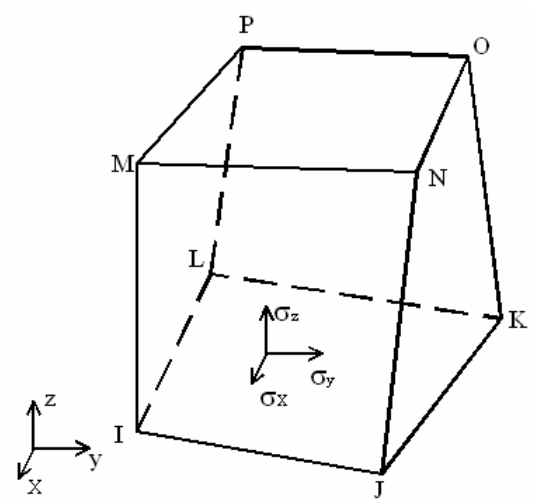

Figura 5.1 - Elemento SOLID 65 - 3D Reinforced Concrete Solid, adaptada de Ansys Release (1999). 
A malha de elementos finitos dos blocos vazados de concreto são compostas por elementos com tamanho máximo de $2,4 \mathrm{~cm}$. Sua geometria é apresentada na Figura 5.2a, totalizando 1248 elementos. Realizaram-se simulações com elementos de dimensão máxima de $1,2 \mathrm{~cm}$, contudo os resultados rõo diferiram significativamente, apresentando valores aproximadamente $4,3 \%$ maiores.

A Figura 5.2b apresenta a geometria da malha da placa, com configuração semelhante à do bloco para que houvesse coincidência dos nós.

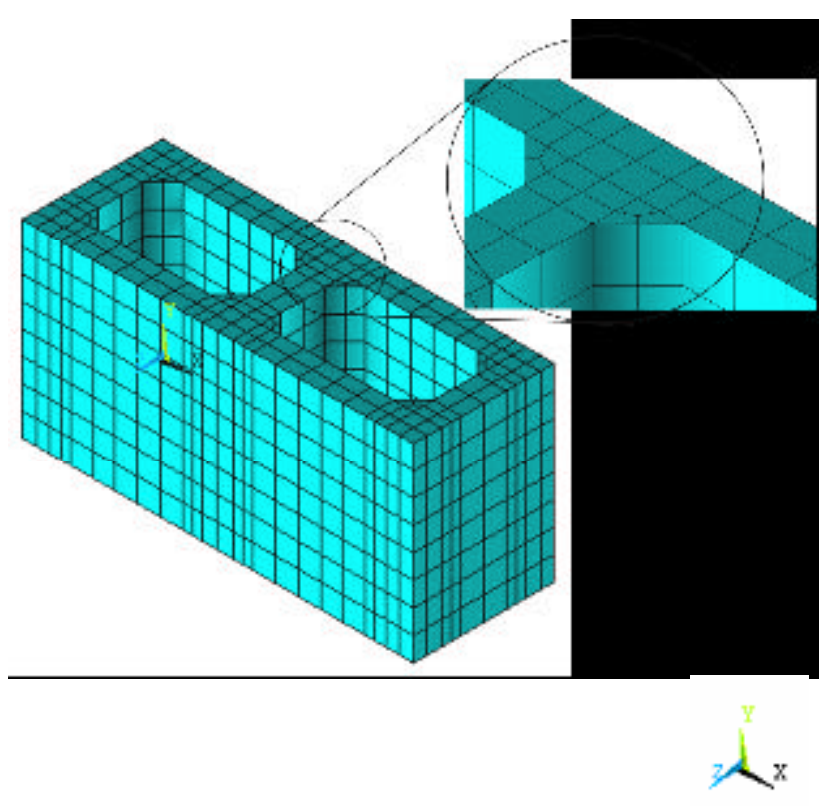

(a)

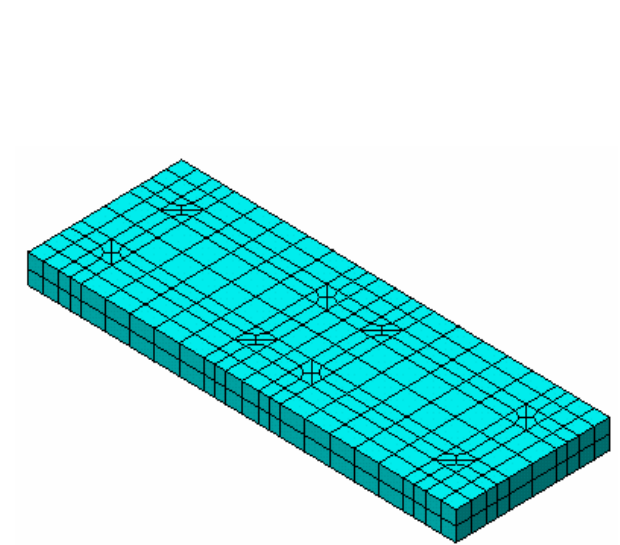

(b)

Figura 5.2 - Malha de elementos finitos do bloco vazado de concreto (a) e da placa de aço (b).

Nas modelagens do bloco com maior altura, utiliza-se a mesma geometria de malha tanto para o bloco quanto para a placa, todavia, o número de elementos é três vezes maior que o bloco convencional, totalizando 3744 elementos.

Utilizam-se as propriedades do concreto (módulo de elasticidade longitudinal ou de Young e coeficiente de Poisson), obtidas por meio de ensaios em corpos-de-prova cilíndricos $10 \times 20 \mathrm{~cm}$.

Adotam-se para bloco $\mathrm{E}=16200 \mathrm{MPa}$ e $\mathrm{v}=0,19$ e para a placa $\mathrm{E}=205000$ $\operatorname{MPa}$ e $v=0,35$.

Restringiram-se os nós da base do bloco em todas as direções e os do topo nas direções x e z para representar o confinamento exercido pelas placas de ensaio. 


\subsubsection{Deslocamento não uniforme da placa de ensaio}

Aplicourse uma tensão, sobre a área de influência da Figura 5.3, de 0,52 $\mathrm{kN} / \mathrm{cm}^{2}$, uniformemente distribuída nos elementos. Essa tensão corresponde a uma força de aproximadamente $206 \mathrm{kN}$, equivalente a $40 \%$ da força máxima obtida no ensaio do bloco do grupo 10.

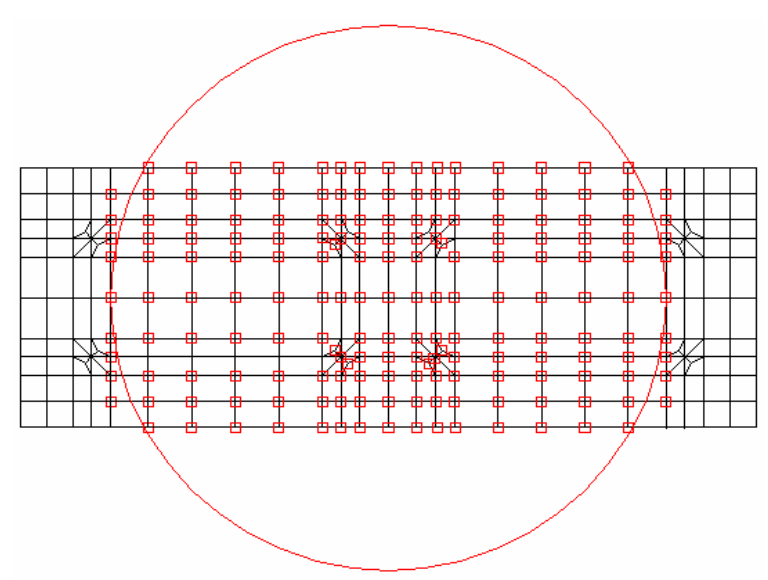

Figura 5.3 - Área de influência do atuador na placa.

Na Figura 5.4 apresenta-se a distribuição de tensões de compressão vertical $\left(\sigma_{\mathrm{y}}\right)$ nas paredes do bloco.

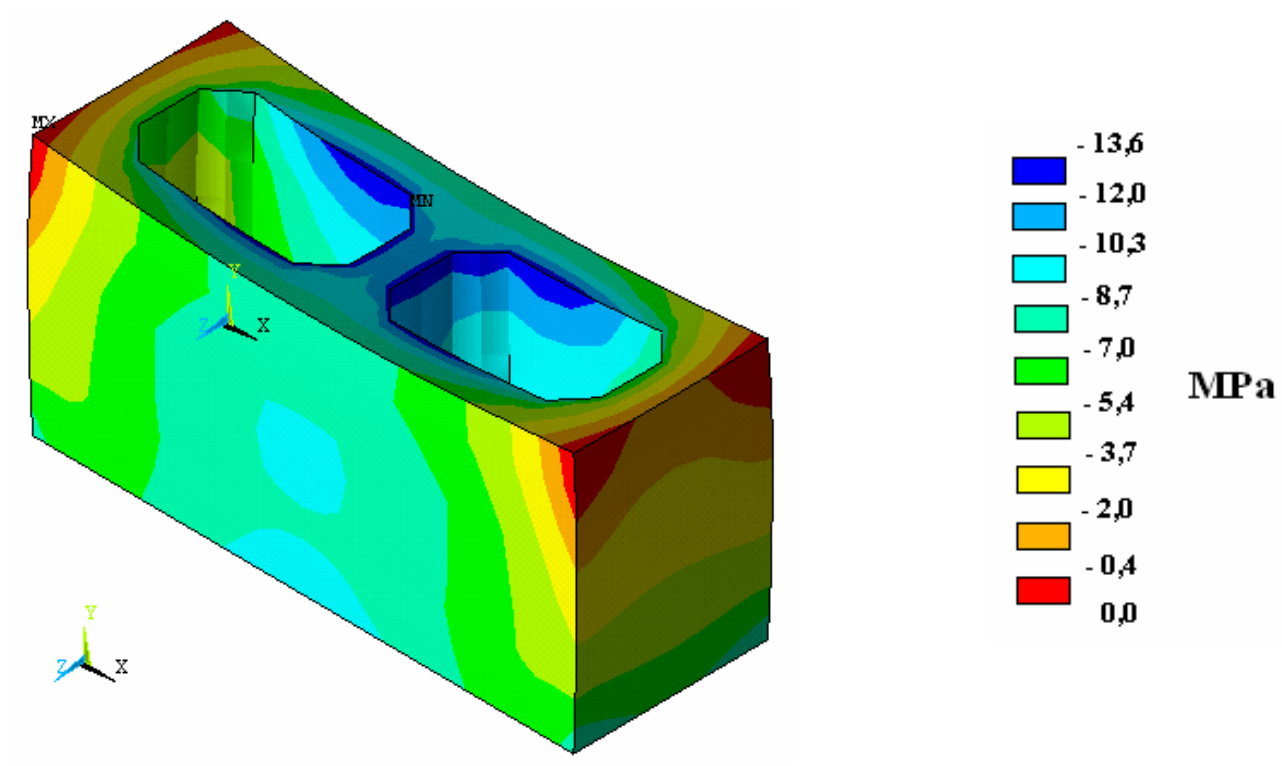

Figura 5.4 - Distribuição das tensões $\sigma_{\mathrm{y}}$ ao longo das paredes do bloco, devida a um carregamento aplicado na região central.

Essa configuração de distribuição de tensões é ocasionada pelo deslocamento não uniforme da placa de ensaio, apresentando maiores valores na região central que nas extremidades. O deslocamento no centro é aproximadamente 3,5 vezes maior que os valores obtidos nas extremidades, conforme ilustrado na Figura 5.5. 

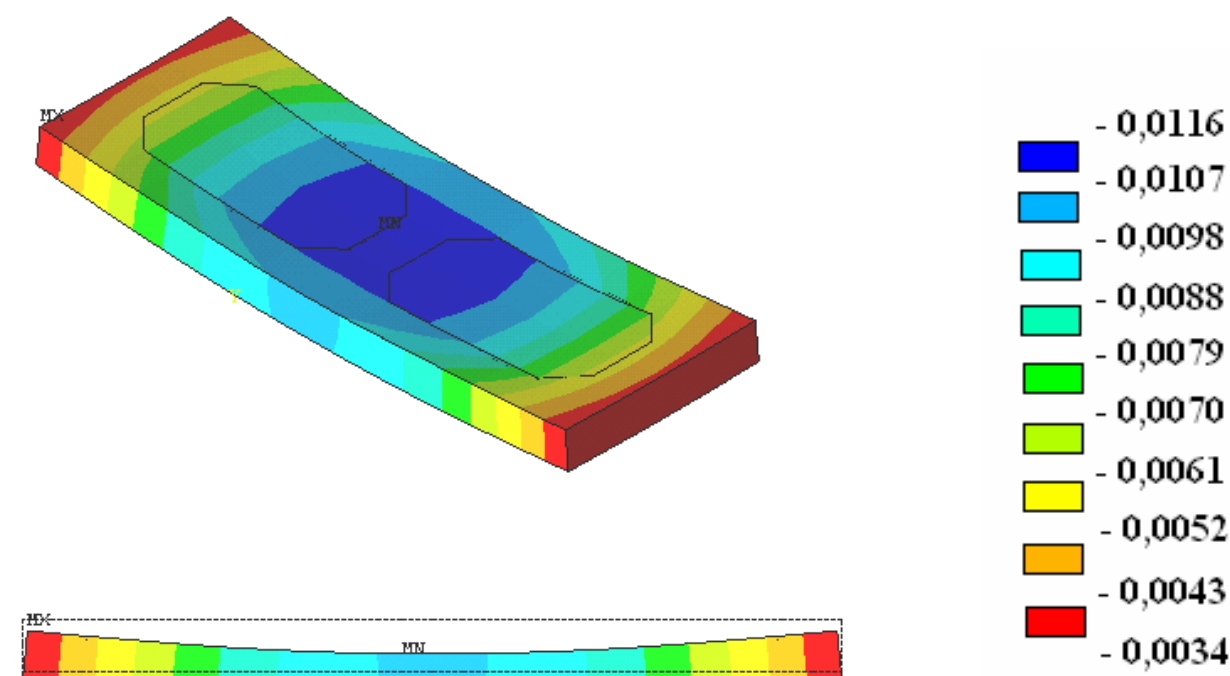

Figura 5.5 - Deslocamentos da placa de ensaio e situação após carregamento em relação à posição original.

Análise mais detalhada da distribuição de tensões nas paredes dos blocos é realizada por meio de perfis obtidos em diversos planos ao longo da altura dos blocos. A localização desses perfis está apresentada na Figura 5.6.

Planos de corte

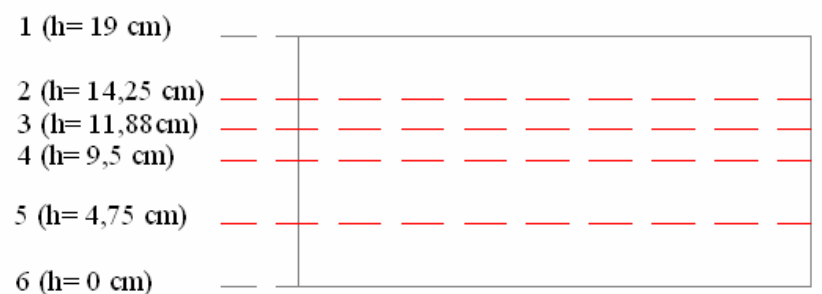

Parede longitudinal

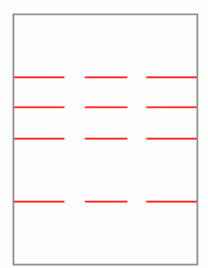

Septo transversal

Figura 5.6 - Planos ao longo da altura dos blocos.

Devido à condição de carregamento, as maiores tensões são obtidas na região central do bloco, em todos os planos analisados, reduzindo-se significativamente em direção às extremidades. Os valores de tensão aumentam nos planos em direção à altura média do bloco, sendo as maiores variações observadas nos pontos mais extremos, já que ocorre uma uniformização das tensões nessa região, pouco solicitada no topo do bloco. A Figura 5.7 ilustra essa configuração. As tensões apresentam valores mais altos e uma menor variação destes na parte interna do bloco (Figura 5.8). O ponto mais extremo da parte interna do bloco coincide com o chanfro que não está na região sob o atuador. 


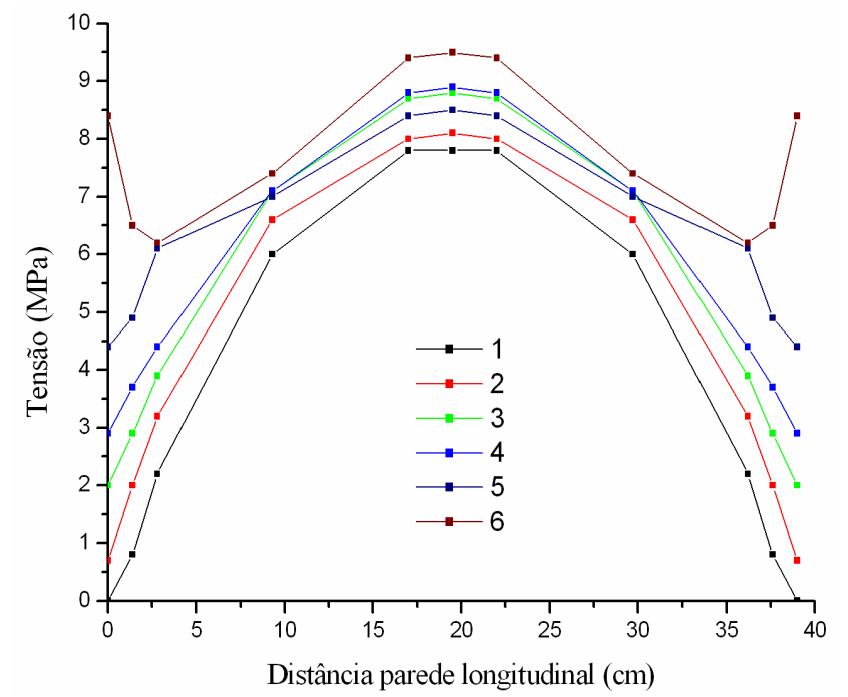

Figura 5.7 - Tensões de compressão $\sigma_{\mathrm{y}}$ em distintos planos na parede longitudinal.

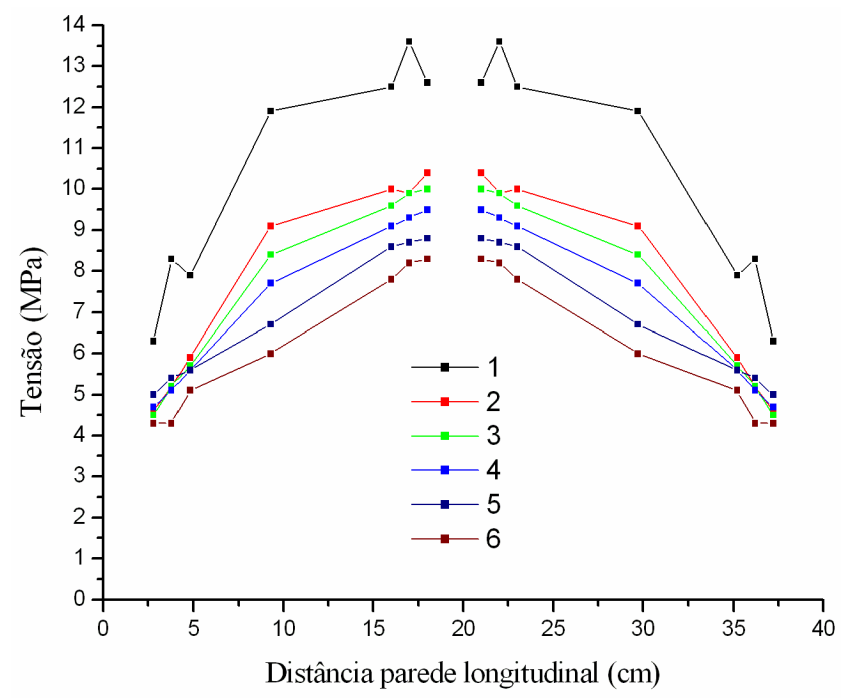

Figura 5.8 - Tensões de compressão $\sigma_{\text {y }}$ em distintos planos na parede longitudinal - parte interna.

Os valores apresentados ao longo do septo transversal são numericamente menores que os obtidos na parede longitudinal em virtude da menor solicitação a que essa região está submetida, inclusive apresentando menor variação entre a região central e os extremos. Como na parede longitudinal, ocorre aumento das tensões em direção ao plano situado na altura média do bloco. O menor deslocamento da placa nessa região justifica os valores obtidos. Internamente, as tensões apresentam valores pouco mais altos e uma menor variação ao longo dos planos. A distribuição de tensões no septo transversal são apresentadas na Figura 5.9 e na Figura 5.10. 


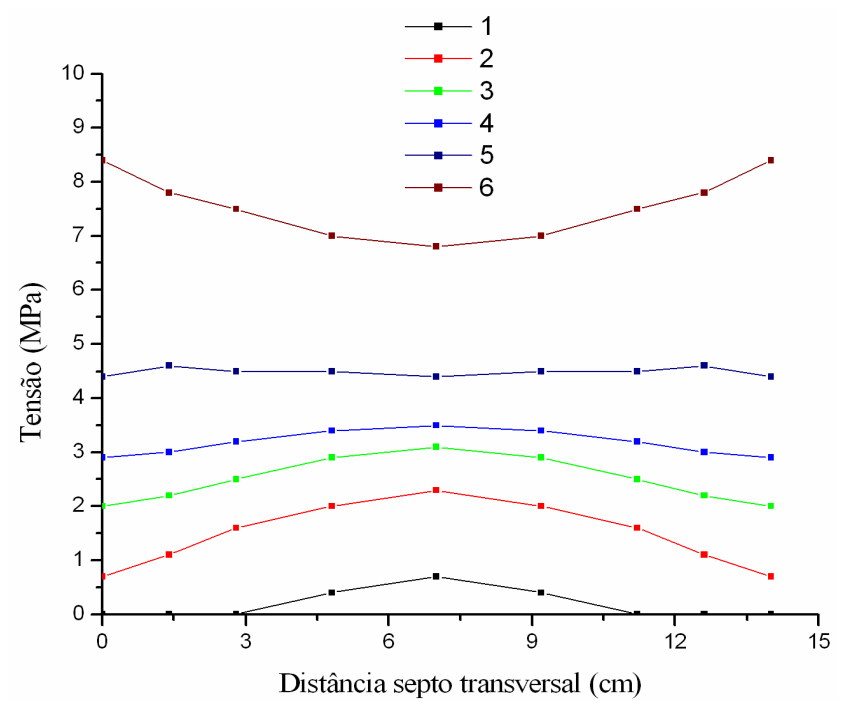

Figura 5.9 - Tensões de compressão $\sigma_{\mathrm{y}}$ em distintos planos no septo transversal.

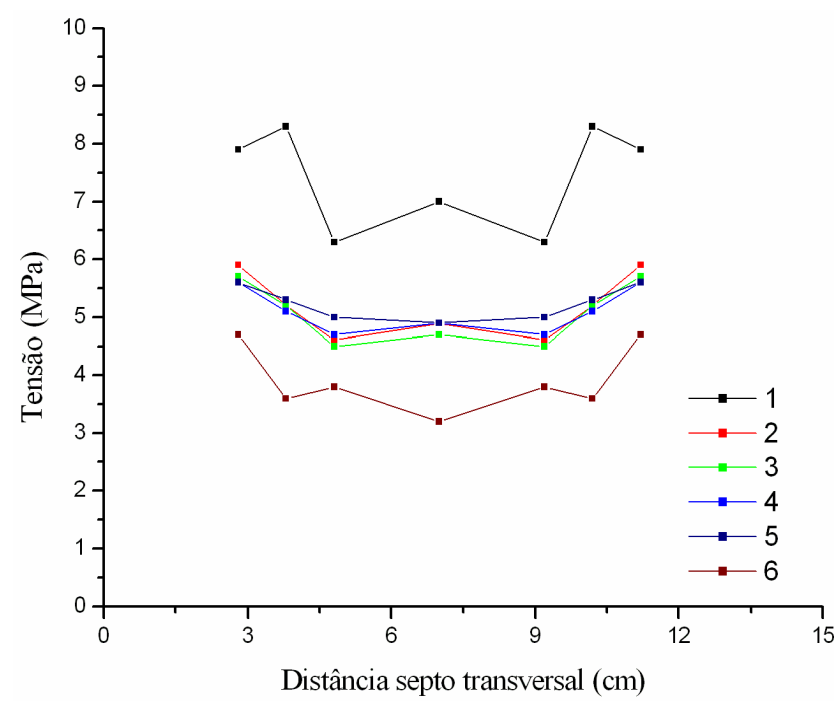

Figura 5.10 - Tensões de compressão $\sigma_{y}$ no septo transversal - parte interna.

Submetido diretamente à ação do carregamento, obtêm-se no septo transversal central as maiores tensões de compressão com uma distribuição uniforme de cada perfil. A diferença dos valores, ao longo da altura, também é reduzida. Na Figura 5.11 apresentam-se os perfis. 


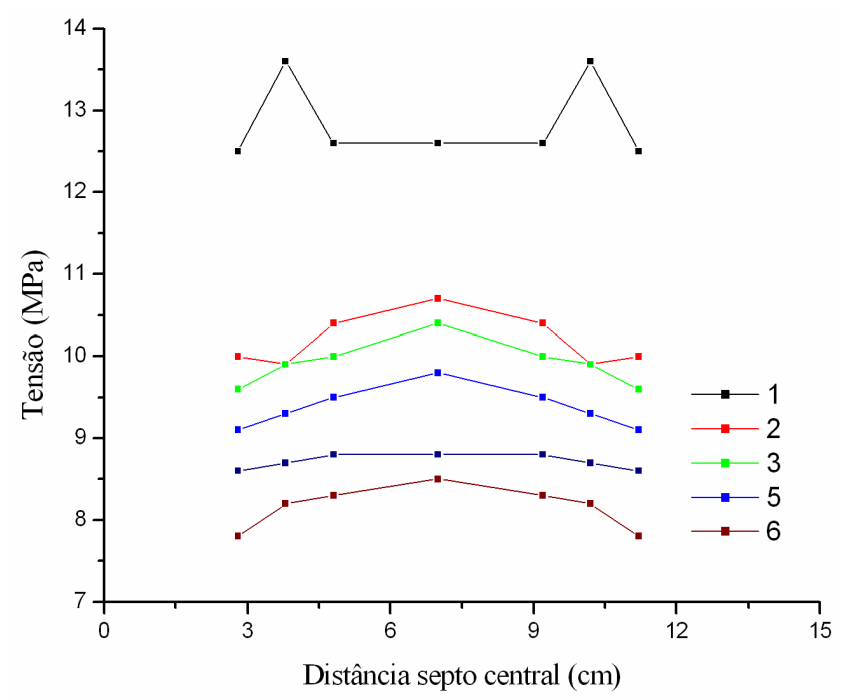

Figura 5.11 - Tensões de compressão $\sigma_{\mathrm{y}}$ em distintos planos no septo transversal central.

\subsubsection{Deslocamento uniforme da placa de ensaio}

Mantêm-se as mesmas propriedades do concreto e condições de carregamento do exemplo anterior. Contudo, para impor um deslocamento uniforme da placa de ensaio adota-se o módulo de elasticidade com valor muito maior que o anterior $(\mathrm{E}=$ $20500 \mathrm{GPa}$ ). Com o aumento da rigidez da placa, obtém-se deslocamento uniforme do topo do bloco.

Devido à modificação das condições de contorno, a distribuição de tensões é significativamente alterada. A Figura 5.12 apresenta essa distribuição.

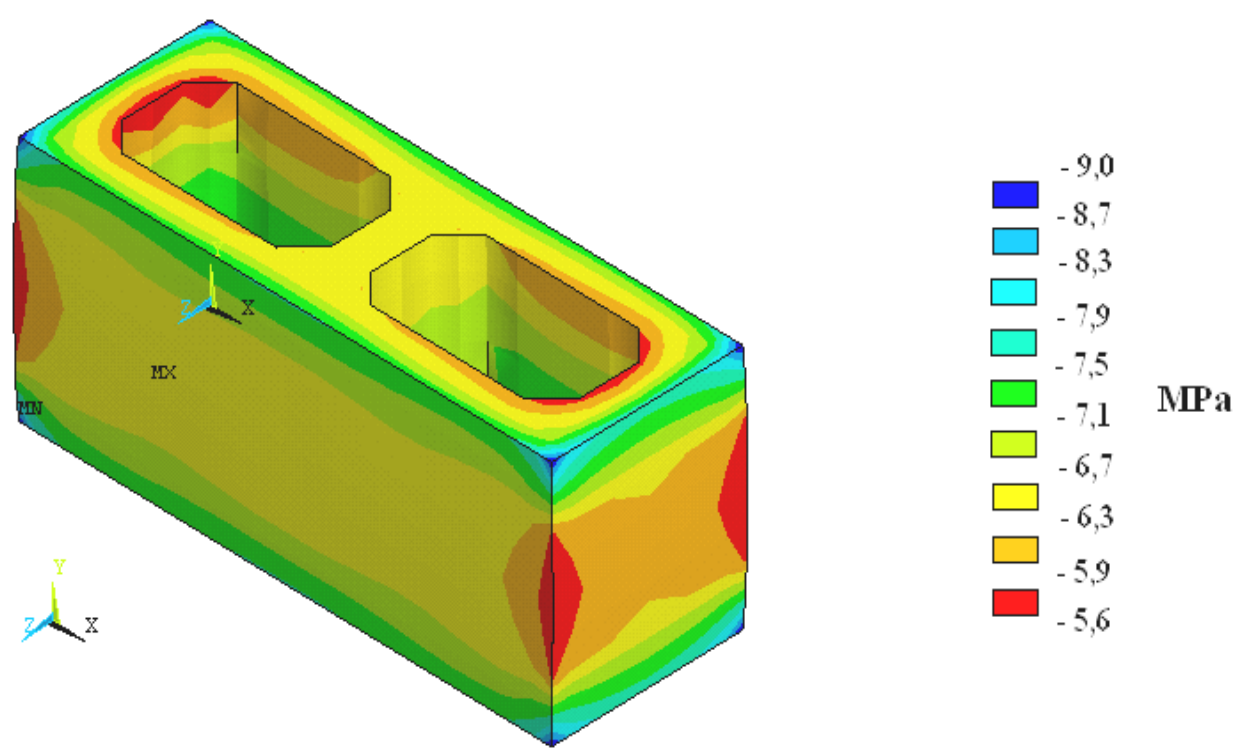

Figura 5.12 - Distribuição das tensões $\sigma_{\mathrm{y}}$ ao longo das paredes de um bloco - deslocamento uniforme do topo do bloco. 
Como apresentado na Figura 5.13 é evidente a maior uniformidade dos valores das tensões de compressão ao longo da parede longitudinal, inclusive apresentado pouca variação nos planos ao longo da altura. $\mathrm{O}$ topo do bloco, submetido à compressão triaxial, apresenta os maiores valores de tensão. Na parte interna, observa-se o aumento das tensões de compressão, apresentando inclusive valores mais altos que os do topo do bloco (Figura 5.14). Enquanto as tensões variam aproximadamente em $9 \mathrm{MPa}$ no modelo anterior, a variação agora é inferior a $1 \mathrm{MPa}$ nos pontos mais distantes do topo do bloco.

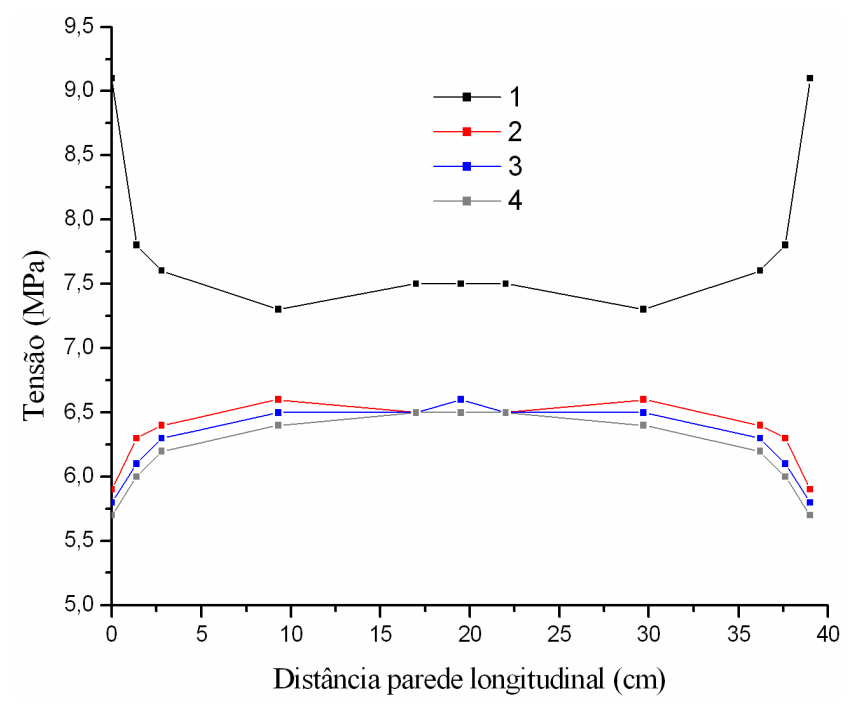

Figura 5.13 - Tensões de compressão $\sigma_{\mathrm{y}}$ em distintos planos na parede longitudinal.

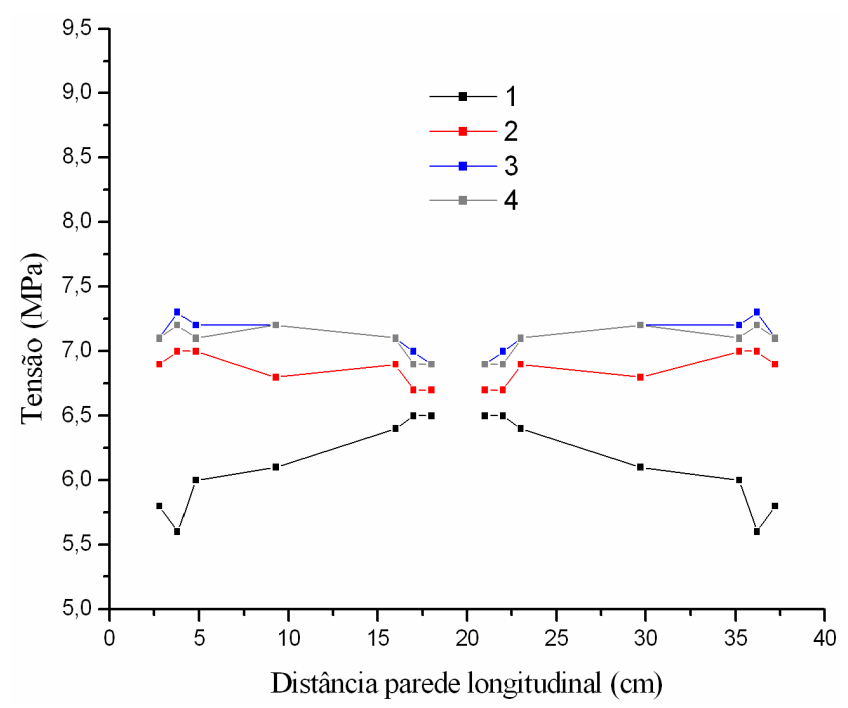

Figura 5.14 - Tensões de compressão $\sigma_{y}$ em distintos planos na parede longitudinal - parte interna.

No septo transversal as tensões de compressão são um pouco menores que as da parede longitudinal, entretanto, permanece a mesma constância de valores ao longo 
do comprimento e os elevados valores no topo do bloco. Na parte interna, com exceção do topo do bloco, as tensões de compressão apresentam valores mais altos que os observados na parte externa. A situação está ilustrada na Figura 5.15 e na Figura 5.16. Comparando-se com o modelo anterior, os valores de tensão são maiores devido a aumento da influência do carregamento nessa região.

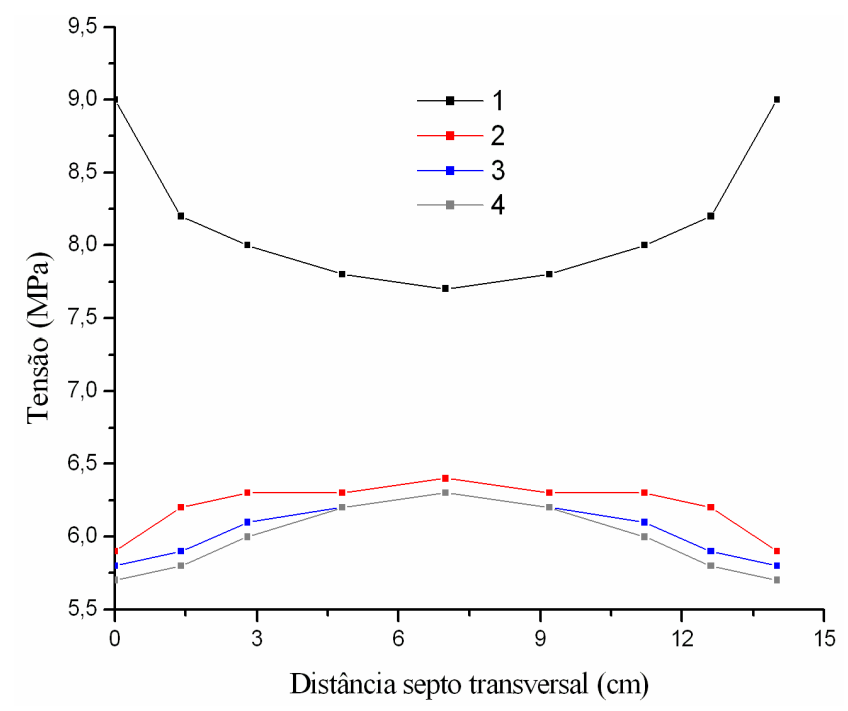

Figura 5.15 - Tensões de compressão $\sigma_{y}$ em distintos planos no septo transversal.

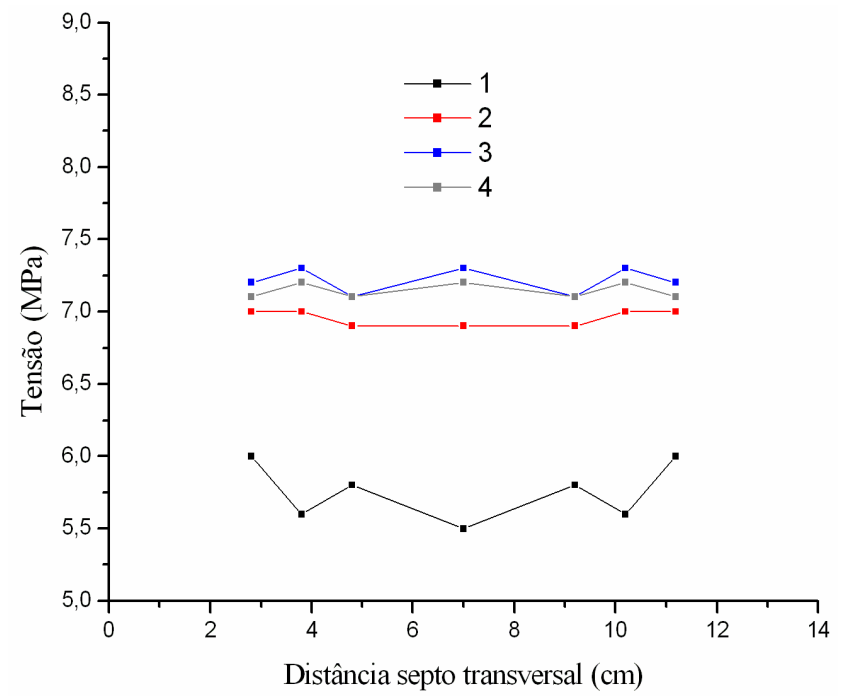

Figura 5.16 - Tensões de compressão $\sigma_{y}$ em distintos planos no septo transversal - parte interna.

As tensões no septo transversal central, apesar de apresentarem valores um pouco inferiores à do septo transversal, mantêm-se uniformes (Figura 5.17). 


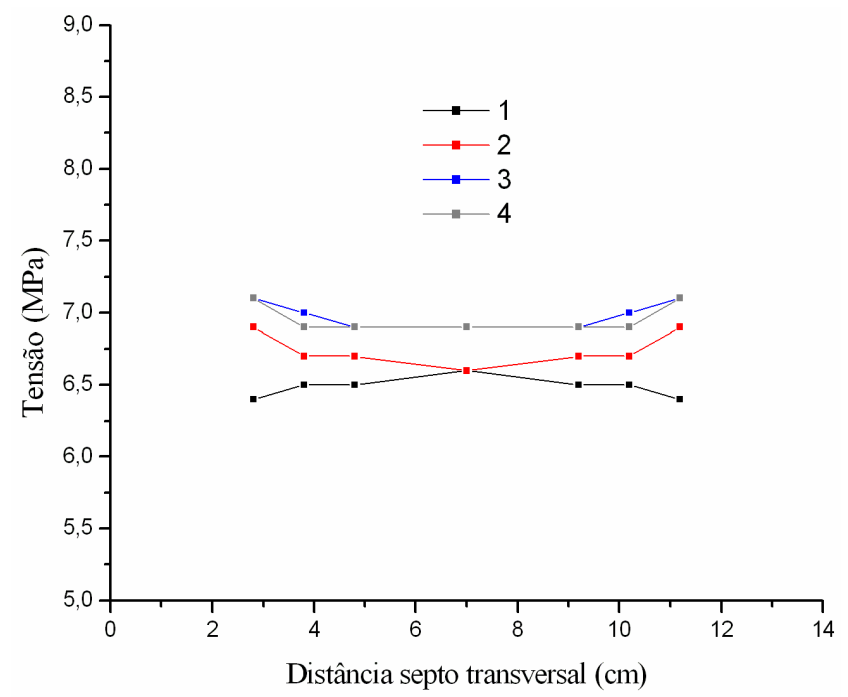

Figura 5.17 - Tensões de compressão $\sigma_{y}$ em distintos planos no septo transversal central.

\subsubsection{Considerações sobre os modelos}

Além da diferença de valores entre o modelo I (deslocamento não uniforme da placa) e o modelo II (deslocamento uniforme da placa), nota-se no modelo I a tendência do decréscimo dos valores nos perfis de tensão em direção às extremidades.

As deformações obtidas teórica e experimentalmente (Figura 5.18) ao longo da parede longitudinal não se aproximaram numericamente. $\mathrm{O}$ modelo teórico I apresenta uma tendência de configuração semelhante à curva obtida experimentalmente, enquanto que a uniformidade da curva teórica II se distancia das outras duas.

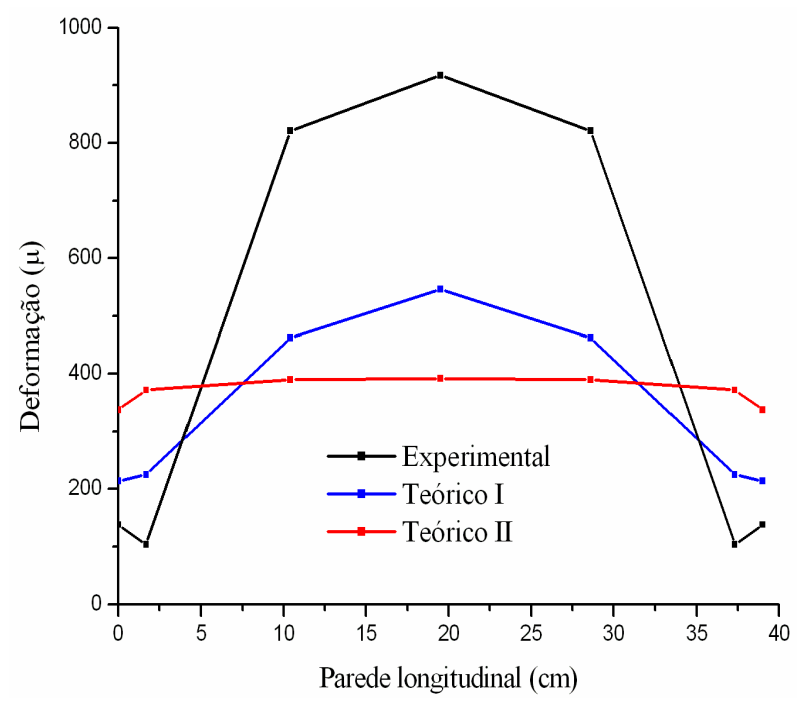

Figura 5.18 - Deformação em diversos pontos do bloco. 
Os modelos teóricos não se aproximaram do modelo experimental, todavia, a comparação entre eles pôde esclarecer o comportamento do bloco de concreto quando submetido às duas condições distintas de ensaio.

Com isso, pode-se afirmar que os resultados experimentais foram influenciados pelo deslocamento não uniforme da placa de ensaio, levando a diferenças consideráveis nos valores de deformação em distintos pontos do bloco.

Modelos mais refinados podem ser elaborados, utilizando-se da análise nãolinear e considerando o contato entre a placa de aço e o bloco de concreto, resultando em um comportamento mais próximo do real.

A Figura 5.19 apresenta a distribuição de tensões de compressão no prisma, destacando-se a uniformização das tensão em direção ao centro do bloco. Em consequiência, as deformações no centro apresentam menores diferenças entre os pontos do centro e extremidade. A Figura 5.20 apresenta os perfis de deformação do prisma obtidos em sete planos de altura diferentes, da base do bloco até uma altura de $52,3 \mathrm{~cm}$.

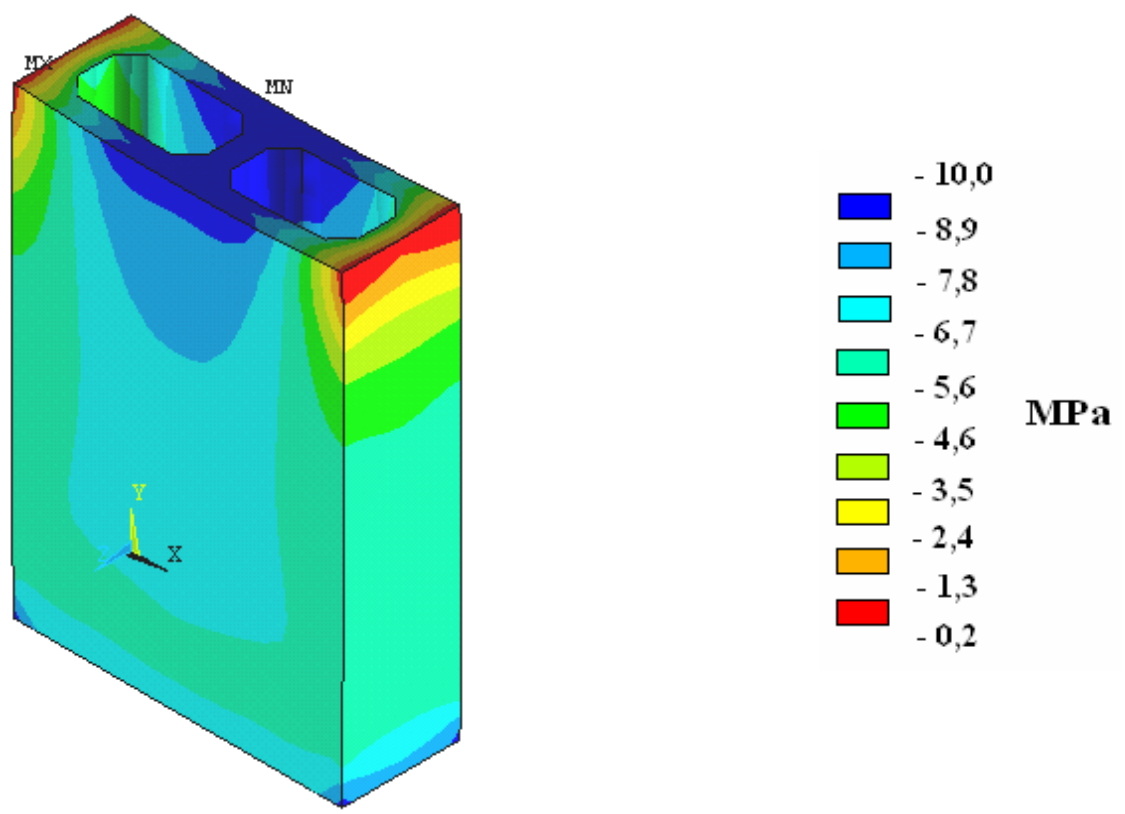

Figura 5.19 - Distribuição das tensões de compressão $\sigma_{\text {y }}$ no bloco de altura diferenciada. 


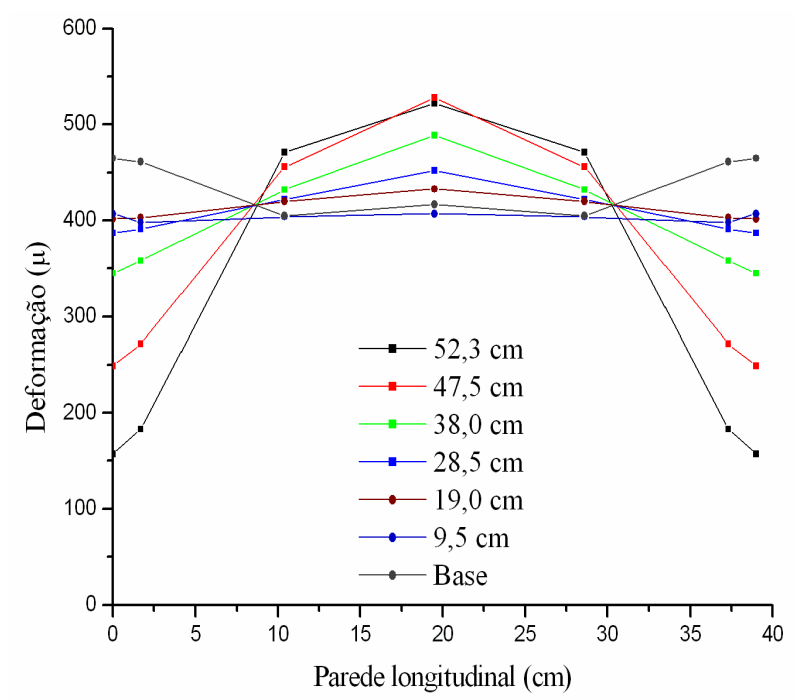

Figura 5.20 - Perfis de deformação dos prismas ao longo de diversas alturas.

Portanto, as menores diferenças entre os valores de deformação, em relação aos blocos, obtidas entre o centro e a extremidade dos prismas são ocasionadas pela uniformização de tensão ao longo da altura destes elementos. Novamente, enfatiza-se que o modelo não representa o comportamento real do elemento, auxiliando apenas nas conclusões dos resultados experimentais.

\subsection{Análise por associação dos resultados experimentais}

Analisam-se as tensões e deformações obtidas nos distintos pontos instrumentados dos blocos vazados de concreto a partir das propriedades mecânicas do concreto que o constitui. Tais propriedades são obtidas a partir de ensaios em corpos-deprova cilíndricos $10 \times 20 \mathrm{~cm}$. Obtém-se a curva tensão-deformação do bloco a partir das propriedades mecânicas do concreto.

\subsubsection{Cálculo da força teórica resistente do bloco}

Divide-se o bloco em diversas áreas distintas, cada uma representando uma região do bloco. Como ilustrado na Figura 5.21, o bloco é discretizado em 12 áreas, nem todas instrumentadas durante as análises experimentais. Por isso, utilizam-se os valores médios de deformação, em diversas etapas de carregamento, referentes a um determinado grupo de áreas (A, B, C ou D). Adota-se, dessa forma, um único valor de deformação para cada grupo de áreas. $\mathrm{Na}$ análise experimental os pontos instrumentados são identificados por números, de 1 a 4 . 


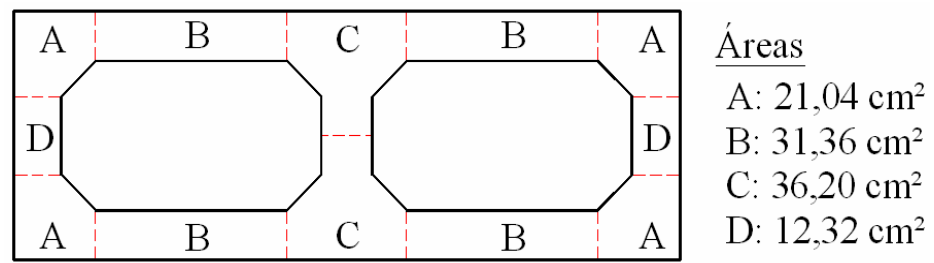

Figura 5.21 - Discretização do bloco em áreas e seus respectivos valores.

Com os valores médios de deformação referentes a cada grupo de áreas, obtêm-se as tensões sob as quais está submetido um corpo-de-prova cilíndrico de $10 \mathrm{x}$ $20 \mathrm{~cm}$, referente àquelas deformações. Atribuem-se as tensões correspondentes a cada área do bloco. Utilizou-se critério empírico na divisão das áreas, não havendo nenhuma consideração e/ou otimização proeminente.

Com o valor da tensão correspondente em cada área, obtém-se a força atuante. Denomina-se força teórica resistente do bloco, $\mathrm{F}_{\mathrm{b}, \text { resit }}$, como sendo o somatório dessas forças. $\mathrm{O}$ cálculo foi realizado para cinco etapas de carregamento, referentes à tensão máxima dos ensaios. Tais parâmetros são obtidos, para cada área discretizada, a partir da Equação (5.1).

$$
\mathrm{F}_{\mathrm{b}, \text { resist }}=\sum_{\mathrm{i}=1}^{\mathrm{n}} \mathrm{s}_{\mathrm{ci}} \mathrm{A}_{\mathrm{bi}}
$$

$\mathrm{F}_{\mathrm{b}, \text { resist }}$ é a força resistente do bloco calculada;

$\mathrm{S}_{\mathrm{ci}}$ é a tensão no $\mathrm{CP}$ de concreto referente à deformação média $\mathrm{e}_{\mathrm{bi}}$. Esta deformação é obtida no bloco em cada área discretizada - associada ao ponto i;

$\mathrm{A}_{\mathrm{i}}$ é a área influente em um determinado ponto i, discretizadas no bloco;

O módulo de elasticidade assumido do concreto, $\mathrm{E}_{\mathrm{c}}$, para cada nível de tensão é representado pela formulação da Equação (5.2) e obtido implicitamente a partir da consideração das diversas tensões $\mathrm{S}_{\mathrm{ci}}$.

$$
\mathrm{s}_{\mathrm{c}}=\mathrm{E}_{\mathrm{c}} \mathrm{e}_{\mathrm{c}} \rightarrow \mathrm{E}_{\mathrm{c}}=\frac{\mathrm{s}_{\mathrm{c}}}{\mathrm{e}_{\mathrm{c}}}
$$

Os valores obtidos das forças resistentes dos blocos estão agrupados na Tabela 5.1 . 
Tabela 5.1 - Força resistente dos blocos em diversas etapas do ensaio.

\begin{tabular}{|c|c|c|c|c|}
\hline & $\begin{array}{c}\text { Etapa do } \\
\text { ensaio }\end{array}$ & $\begin{array}{r}\mathrm{F}_{\text {atuad }}{ }^{1} \\
(\mathrm{kN})\end{array}$ & $\begin{array}{c}\mathrm{F}_{\mathrm{b}, \text { resist }} \\
(\mathrm{kN})\end{array}$ & $\frac{\mathrm{F}_{\mathrm{b} \text {,resist }}}{\mathrm{F}_{\text {atuad }}}$ \\
\hline \multirow{5}{*}{$\begin{array}{c}\text { Grupo } \\
10\end{array}$} & $0,2 \mathrm{~F}_{\max }$ & 103,7 & 140,5 & 1,36 \\
\hline & $0,4 \mathrm{~F}_{\max }$ & 206,6 & 265,9 & 1,29 \\
\hline & $0,6 \mathrm{~F}_{\max }$ & 309,8 & 348,1 & 1,12 \\
\hline & $0,8 \mathrm{~F}_{\max }$ & 413,1 & 421,3 & 1,02 \\
\hline & $\mathrm{F}_{\max }$ & 516,3 & 505,2 & 0,98 \\
\hline \multirow{5}{*}{$\begin{array}{c}\text { Grupo } \\
20\end{array}$} & $0,2 F_{\max }$ & 124,5 & 169,7 & 1,36 \\
\hline & $0,4 \mathrm{~F}_{\max }$ & 249,0 & 331,7 & 1,33 \\
\hline & $0,6 \mathrm{~F}_{\max }$ & 373,5 & 442,0 & 1,18 \\
\hline & $0,8 \mathrm{~F}_{\max }$ & 498,0 & 528,6 & 1,06 \\
\hline & $\mathrm{F}_{\max }$ & 622,5 & 558,9 & 0,90 \\
\hline \multirow{5}{*}{$\begin{array}{c}\text { Grupo } \\
30\end{array}$} & $0,2 \mathrm{~F}_{\max }$ & 216,4 & 279,9 & 1,29 \\
\hline & $0,4 \mathrm{~F}_{\max }$ & 432,8 & 573,1 & 1,23 \\
\hline & $0,6 \mathrm{~F}_{\max }$ & 649,2 & 749,3 & 1,15 \\
\hline & $0,8 \mathrm{~F}_{\max }$ & 865,6 & 922,3 & 1,07 \\
\hline & $\mathrm{F}_{\max }$ & 1082,0 & 1033,3 & 0,96 \\
\hline
\end{tabular}

${ }^{\mathrm{T}}$ Força aplicada pelo atuador da máquina de ensaio.

As maiores diferenças entre os valores da força resistente e da força real aplicada pela máquina de ensaio ocorrem nas etapas iniciais de carregamento. Ocorre redução dessas diferenças com o aumento dos níveis de tensão. Nas duas últimas etapas essa diferença é inferior a $10 \%$, inclusive, com os valores calculados sendo inferiores aos valores da força do atuador nos grupos 10 e 20. Cada grupo é representado por um de seus blocos ensaiados.

O processo de cálculo possui algumas simplificações. As áreas foram definidas sem um critério refinado, com o qual poder-se-ia chegar a um discretização mais próxima ao comportamento real. Ao modificar a geometria das áreas alteram-se os valores da força de cálculo. Consideraram-se valores médios de deformação nos diversos pontos dos blocos, contudo, tem-se a opção de adotar os valores reais em cada ponto instrumentado, e um valor médio apenas onde não existir instrumentação. É possível ainda dividir o bloco em áreas bem menores e, a partir de uma curva aproximada de deformação, calcular as deformações em diversos pontos adicionais. A partir de ensaios com corpos-de-prova de outras geometrias obtêm-se diferentes valores para as deformações no concreto. 
A forma de cálculo não leva em consideração nenhum fator de correção ou ponderação, é empírica, tendo-se a possibilidade de torná-la mais detalhada e obter melhores resultados. Todavia, o valor da força total resultante, apresentou valor próximo ao efetivamente aplicado no ensaio, o que demonstra que a equação de equilíbrio está sendo aproximadamente satisfeita.

\subsubsection{Sobre a curva força-deslocamento do bloco vazado de concreto}

A partir dos resultados da seção anterior, obtêm-se as curvas forçadeslocamento associadas ao bloco vazado de concreto de diversas maneiras. Na Figura 5.22 são apresentadas essas curvas para um bloco de cada grupo de resistência, a partir dos dados da Tabela 5.1.

As curvas teóricas são originadas do cálculo teórico das forças resultantes em áreas discretizadas da seção transversal do bloco ensaiado, associada às deformações médias de cada região discretizada. Tais deformações, são associadas a um diagrama tensão-deformação obtido em ensaio de corpos-de-prova $10 \times 20 \mathrm{~cm}$. A associação de deformações medidas no bloco durante o ensaio com a curva tensão-deformação do CP $10 \times 20 \mathrm{~cm}$ mostra-se coerente, visto que o valor da força total resultante é próximo ao valor efetivamente aplicado no ensaio. Sabe-se que as deformações obtidas no ensaio de blocos não se apresentam uniformes, em decorrência das deformações que ocorrem na placa de ensaio. É possível que se a placa de carregamento fosse muito mais rígida, a associação direta do diagrama tensão-deformação do CP com a geometria do bloco multiplicando-se as tensões nesse diagrama pela área líquida do bloco - oferecesse uma previsão razoável da deformabilidade do bloco.

A curva obtida experimentalmente a partir do ensaio do bloco, considerando a média geral (aritmética) dos deslocamentos medidas nos diversos pontos, inclusive nas extremidades, mostroutse próxima à curva teórica que considera as mesmas medidas de deslocamentos. Os valores de deslocamentos foram obtidos a partir dos valores de deformação do bloco em uma faixa igual a altura de $10 \mathrm{~cm}$, correspondente a base dos extensômetros removíveis. A partir do valor médio correspondente a cada ponto, estendeu-se a deformação à altura total do bloco $(19 \mathrm{~cm})$, desconsiderando portanto a provável variação de deformações ao longo da altura em cada ponto de medição. 


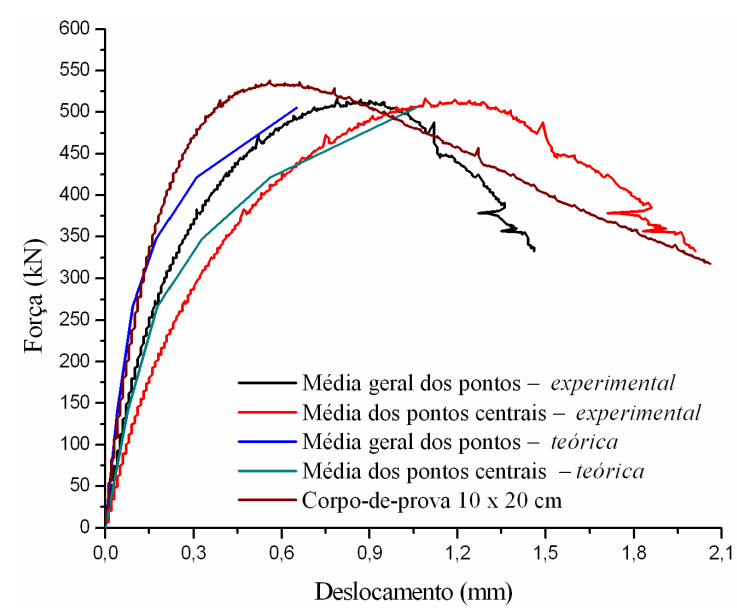

(a)

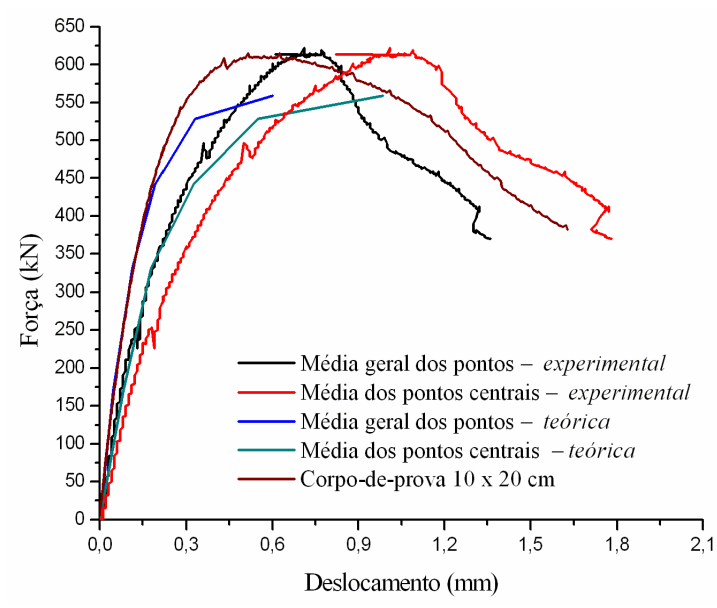

(b)

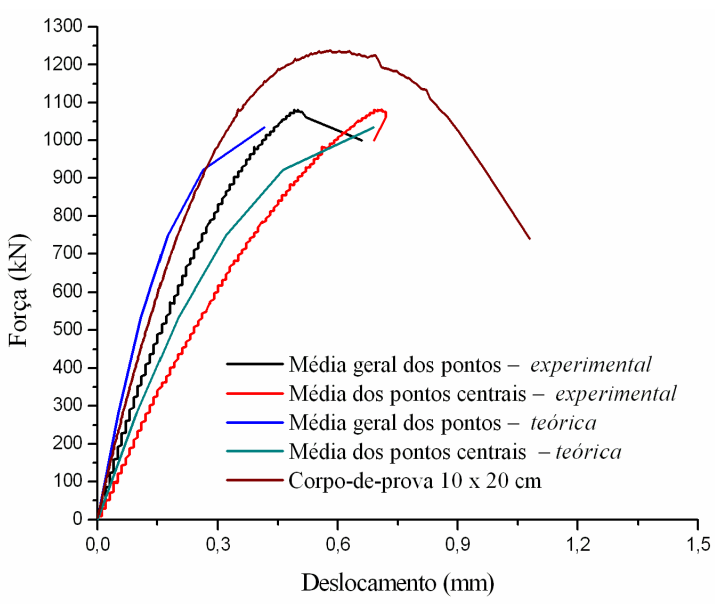

(c)

Figura 5.22 - Curvas força-deslocamento obtidas teórica e experimentalmente. Grupo 10 (a), grupo 20 (b) e grupo 30 (c).

A curva experimental que considera apenas os deslocamentos nos pontos mais deformáveis do bloco, situados no centro da parede longitudinal, mostra a rigidez ainda menor do bloco no ensaio. Portanto, a consideração de uma deformação média com valores próximos às deformações máximas medidas no ensaio do bloco superestima a deformabilidade do bloco.

Multiplicando-se a tensão no corpo-de-prova pela área líquida do bloco e estendendo os seus deslocamentos, a partir da deformação no trecho central, a toda a sua altura, obteve-se a curva do corpo-de-prova, que apresenta rigidez próxima à obtida por meio do cálculo teórico da curva que considera os deslocamentos em todos os pontos do bloco.

$\mathrm{Na}$ análise da segurança das estruturas de concreto, em geral, há coeficientes de modificação $\left(\gamma_{\bmod }\right)$ que consideram, por exemplo, a diferença entre a resistência do concreto medida em CPs e aquela que provavelmente se encontra na estrutura real. 
De modo análogo, coeficientes de modificação (valores pré-estabelecidos) ou algoritmos (expressões de cálculo parametrizadas) podem ser utilizados nos resultados experimentais. Por exemplo, em corpos-de-prova cilíndricos há correlações conhecidas que levam em conta o efeito de tamanho (ou de escala). Os CPs maiores apresentam resistências menores. Entre CPs cilíndricos, cúbicos e prismáticos, além do fator tamanho há diferenças no efeito de confinamento nos ensaios. Em relação aos blocos, o número de variáveis aumenta, o que não permite estabelecer uma única correlação por meio de coeficientes de modificação ou de ajuste único.

\subsubsection{Deformabilidade do bloco vazado de concreto}

Compara-se a deformabilidade dos blocos vazados de concreto a partir das propriedades mecânicas do material obtida em CP 10 x $20 \mathrm{~cm}$. No Capítulo 4 obtiveram-se duas curvas que aproximavam a correlação entre a resistência de CP $10 \mathrm{x}$ $20 \mathrm{~cm}$ com a resistência dos blocos vazados de concreto. Utiliza-se nessa associação a curva exponencial, apresentada na Equação (5.3), por esta apresentar valores mais coerentes quando calculadas as resistências mais baixas do bloco.

$$
\mathrm{f}_{\mathrm{b}}=1,5 \mathrm{f}_{\mathrm{c}}^{0,8271}
$$

Define-se, nessa análise, módulo de elasticidade aparente do bloco vazado de concreto, $\mathrm{E}_{\mathrm{b}, \mathrm{ap}}$, como sendo a inclinação da reta que une os pontos referentes a uma deformação de $50 \mu$ e à tensão equivalente a $40 \%$ da resistência à compressão do bloco, obtidos em um determinado ponto. A Tabela 5.2 apresenta os módulos de elasticidade aparente dos blocos - valor médio entre os pontos 2 e 3 - e dos corpos-de-prova dos três grupos de resistência.

Tabela 5.2 - Módulos de elasticidade do bloco e do concreto nos três grupos de resistência.

\begin{tabular}{ccc}
\hline Grupo & $\mathrm{E}_{\mathrm{b}, \mathrm{ap}}{ }^{1}(\mathrm{MPa})$ & $\mathrm{E}_{\mathrm{c}}(\mathrm{MPa})$ \\
\hline 10 & 7462 & 16199 \\
20 & 8991 & 19407 \\
30 & 14070 & 25484 \\
\hline
\end{tabular}

A Figura 5.23 apresenta a correlação entre esses dois parâmetros. Obtiveram-se duas curvas de aproximação para o intervalo em questão, uma linear (Equação (5.4)) e outra exponencial (Equação (5.5)). 


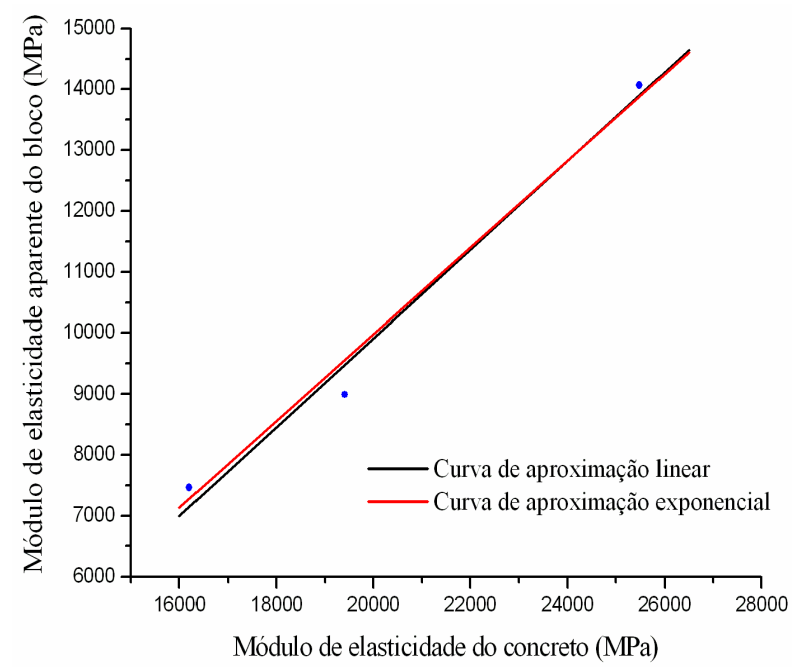

Figura 5.23 - Correlação entre o módulo de elasticidade do concreto, obtido em CP 10 x $20 \mathrm{~cm}$, e o módulo de elasticidade aparente do bloco - referente ao valor médio obtido nos pontos centrais.

$$
\begin{aligned}
& \mathrm{E}_{\mathrm{b}, \mathrm{ap}}=0,73 \mathrm{E}_{\mathrm{c}}-4648 \\
& \mathrm{E}_{\mathrm{b}, \mathrm{ap}}=0,0077 \mathrm{E}_{\mathrm{c}}^{1,4193}
\end{aligned}
$$

Ambas equações conduzem a valores próximos sendo, na presente análise, utilizada a Equação (5.4).

A metodologia básica consiste em:

- A partir das propriedades mecânicas do concreto $\left(\mathrm{f}_{\mathrm{c}} \mathrm{e} \mathrm{E}_{\mathrm{c}}\right)$, obtidas em corpos-de-prova cilíndricos, determinam-se as propriedades mecânicas dos blocos ( $f_{b}$ e $\left.E_{b, a p}\right)$ por meio das Equações (5.3) e (5.4);

- Calcula-se a deformação correspondente, do bloco e do corpo-de-prova, a uma tensão equivalente a $40 \%$ da resistência máxima desses elementos, adotando $\mathrm{s}=\mathrm{Ee}$.

- Define-se o diagrama tensão-deformação (trecho linear) para cada um dos casos, atribuindo-se um coeficiente de ajuste a entre as duas curvas. O coeficiente é definido como sendo a razão entre a inclinação das retas.

- Por fim, ajusta-se a curva tensão-deformação do corpo-de-prova de concreto, corrigindo a sua resistência em relação a resistência do bloco (Equação (5.3)) e as deformações pelo coeficiente a . 
Dessa forma, obtém-se uma curva tensão-deformação do bloco de concreto a partir das propriedades mecânicas do concreto obtidas em corpos-de-prova cilíndricos $10 \times 20 \mathrm{~cm}$.

Tabela 5.3 - Parâmetros utilizados no cálculo da curva tensão-deformação do bloco

\begin{tabular}{cccccccc}
\hline Grupo & $\mathrm{f}_{\mathrm{c}}$ & $\mathrm{f}_{\mathrm{b}}$ & $\mathrm{E}_{\mathrm{c}}$ & $\mathrm{E}_{\mathrm{b}}$ & $\mathrm{e}_{0,4 \mathrm{f}_{\mathrm{c}}}$ & $\mathrm{e}_{0,4 \mathrm{f}_{\mathrm{b}}}$ & $\mathrm{a}$ \\
\hline 10 & 16,8 & 15,4 & 16199 & 7143 & 415 & 865 & 2,27 \\
20 & 20,4 & 18,1 & 19407 & 9478 & 421 & 765 & 2,04 \\
30 & 41,5 & 32,6 & 25484 & 13902 & 651 & 939 & 1,83 \\
\hline
\end{tabular}

Na Figura 5.24 são apresentadas as curvas tensão-deformação, obtidas a partir das propriedades mecânicas do concreto, juntamente com as curvas tensão-deformação do bloco vazados de concreto resultantes da análise experimental, tomando-se a média das deformações nos pontos centrais.

As curvas obtidas pela análise proposta apresentaram-se próximas às curvas obtidas experimentalmente nos ensaios com blocos. As curvas são próximas nos primeiros níveis de carregamento, apresentando em níveis mais altos maiores diferenças principalmente devido à correlação entre as resistências. Todavia, as curvas teóricas apresentaram sempre a tensão máxima inferior à obtida experimentalmente. Se utilizadas placas com maior rigidez, permitindo uma distribuição mais uniforme das tensões no bloco pode-se conseguir uma melhor aproximação entre a curva tensãodeformação do bloco, obtida pela média geral das deformações, e a curva teórica. 


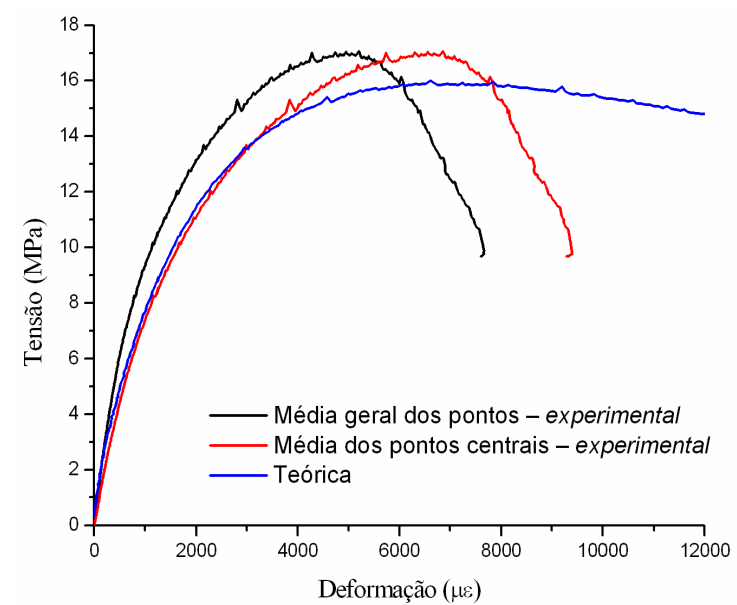

(a)

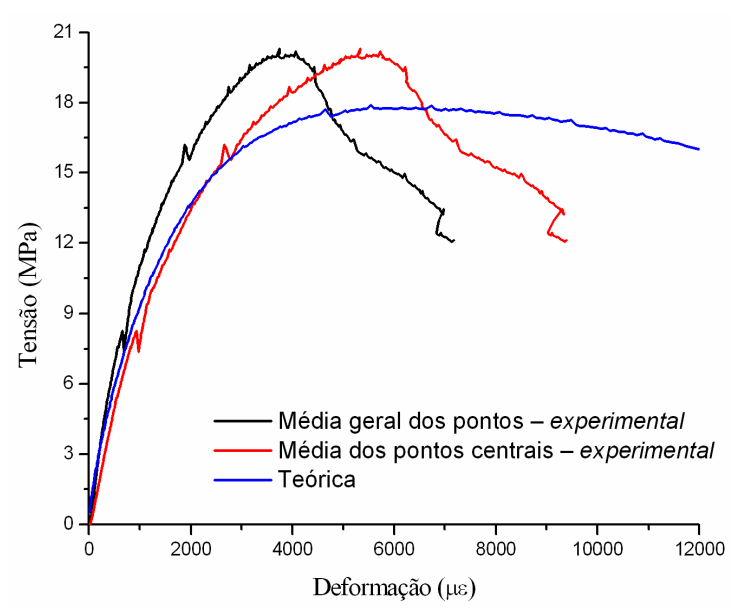

(b)

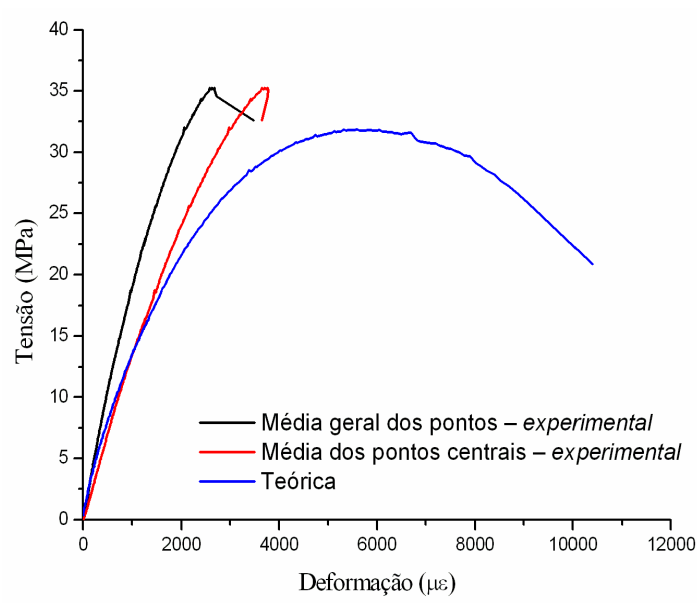

(c)

Figura 5.24 - Curvas tensão-deformação do bloco, obtidas a partir das propriedades mecânicas dos corpos-de-prova, e curvas tensão-deformação do bloco obtidas experimentalmente adotandose a média das deformações em todos os pontos e apensa nos pontos centrais. Grupos 10 (a), 20 (b) e 30 (c). 


\section{CONCLUSÃO}

Apesar dos diversos fatores que interferem na resistência e comportamento estrutural dos blocos vazados de concreto, prismas e paredes, a tecnologia atual da Alvenaria Estrutural permite o conhecimento prévio do comportamento destes elementos. Tal fato é atribuído à vasta quantidade de análises teóricas e experimentais, as quais identificam os fatores interdependentes nas diversas condições de ensaio. Contudo, são ausentes investigações detalhadas que discorram sobre as reais propriedades mecânicas dos materiais que constituem tais elementos.

Defronta-se com diversas pesquisas que objetivam correlacionar as propriedades mecânicas do bloco e do material que o constitui, contudo, estas se limitam à correlação direta entre os valores da resistência à compressão dos elementos. Ainda assim, os resultados mostram-se bastante controversos em razão da variabilidade na forma de obtenção de corpos-de-prova, das dimensões destes e dos distintos materiais ensaiados. Mostra-se necessário um aprofundamento ainda maior nesse estudo para obtenção de correlações mais sólidas, além da caracterização de outras propriedades mecânicas como resistência à tração e módulo de elasticidade.

O presente trabalho estendeu-se nessa linha, padronizando a forma de obtenção de corpos-de-prova e blocos vazados com a utilização de concreto plástico. Os corposde-prova cilíndricos $10 \times 20 \mathrm{~cm}$ e $15 \times 30 \mathrm{~cm}$ foram escolhidos dentre as diversas geometrias, por apresentarem resultados mais próximos à resistência do bloco vazado em relação à sua área líquida. Os seus módulos de elasticidade apresentaram valores aquém dos valores obtidos por meio das diversas formulações prescritas por distintas normas. A vasta utilização dos corpos-de-prova cilíndricos na tecnologia do concreto também justifica sua adoção. 


\subsection{Comportamento dos elementos}

Os elementos de concreto apresentam comportamento distintos quando submetidos a distintas condições de ensaio.

Devido ao efeito de confinamento, os blocos e corpos-de-prova apresentam ruína do tipo cisalhamento cônico. Diferentemente do que ocorre nesses elementos com pequena relação altura:espessura, ms ensaios com prismas constituídos por dois e três blocos interligados com adesivo à base de epóxi, devido à sua maior altura, o comportamento modifica-se. Inicia-se com fissuração vertical, primeiramente nas paredes longitudinais e, posteriormente, nos septos transversais. A perda de rigidez nas paredes longitudinais induz ao aumento de fissuração nos septos transversais. A ruína ocorre pela separação das paredes longitudinais e septos transversais. A camada de adesivo à base de epóxi pode influenciar o comportamento dos prismas. Esta situação se aproxima do comportamento dos blocos quando ensaiados com placa-escova, livres da restrição lateral exercida pela placa de ensaio, que apresentam fissuração vertical.

Nos ensaios à tração indireta, o modo de ruína é frágil, tanto nos ensaios com corpos-de-prova quanto nos ensaios com blocos. A ruína dos elementos é caracterizada por sua divisão em duas partes distintas.

\subsection{Propriedades mecânicas dos elementos e deformação do bloco}

Os resultados obtidos na análise experimental são particulares à metodologia empregada, geometria do bloco vazado de concreto e níveis de resistências do concreto.

A relação entre a resistência à tração do concreto e sua resistência à compressão, obtidas por meio de ensaios, apresentoutse bastante próxima às equações propostas pelas diversas bibliografias, justificando a adoção dessas relações no decorrer do trabalho. Realizaram-se ensaios à ração indireta, apesar de saber que o valor de resistência obtido é apenas parâmetro para comparação com a resistência à compressão, diante dos diversos modos de ensaio existentes e, conseqüentemente, diferentes valores obtidos.

A correlação entre a resistência à compressão e à tração do bloco vazado de concreto apresenta comportamento divergente do citado por Cheema e Klingner (1986), apresentando um maior crescimento da resistência à tração com o aumento da 
resistência à compressão. A distinção entre as geometrias dos elementos ensaiados provavelmente influencia tal comportamento.

A relação entre a resistência do bloco vazado de concreto e do corpo-de-prova apresenta diminuição quando se aumenta o nível de resistência do concreto. Ao contrário, a relação entre a resistência à tração dos blocos e do corpo-de-prova diminui.

Os valores de resistência à compressão, módulo de elasticidade e deformação apresentada na ruptura variam quando ensaiados corpos-de-prova com diferentes dimensões e relações altura-espessura, influenciados pelo efeito de confinamento. Aos valores obtidos com blocos vazados deve ser considerada mais uma variável: a geometria distinta dos demais elementos.

Obtiveram-se correlações com baixo nível de variação entre a resistência dos blocos de concreto e a resistência de corpos-de-prova cilíndricos 10 x $20 \mathrm{~cm}$ e 15 x 30 $\mathrm{cm}$.

A partir do conceito de módulo de elasticidade aparente e, adotando-se a média das deformações nos pontos centrais do bloco, obtêm-se boas correlações com os módulos de elasticidade do concreto.

A relação entre a resistência à compressão dos prismas de dois e três blocos e a resistência à compressão de corpos-de-prova diminui com o aumento da altura desses elementos, apresentando resistência mais baixa. A redução da resistência é atribuída à redução do efeito de confinamento na região central dos elementos. Além disso, o adesivo à base de epóxi pode estar alterando a resistência, conforme relato de Corrêa (2003).

Os blocos apresentam maior deformação nos pontos situados no septo transversal central e na parede longitudinal, no ponto médio do vazio do bloco. As menores deformações são obtidas no centro do septo transversal central e na extremidade da parede longitudinal. A geometria do bloco influencia na distribuição de tensões e em suas respectivas deformações, entretanto, o deslocamento não uniforme da placa de ensaio acarretou carregamentos não uniformes. Como conseqüência as deformações nos pontos centrais foram bem maiores que as obtidas nos pontos extremos do bloco. As geometrias e dimensões da placa de ensaio e prato da prensa satisfazem as prescrições da NBR 7184 (1992), assim como estão dentro dos limites sugeridos por diversas normas internacionais, citados por Atkinson (1991).

Os prismas apresentaram diferenças de deformações semelhantes às dos blocos, entretanto com uma menor diferença entre os valores obtidos na região central e 
na extremidade dos elementos. Tal comportamento deve-se à maior altura desses elementos em relação aos blocos, permitindo uma maior uniformização das tensões ao longo de sua altura.

\subsection{Sobre a análise teórica}

Por meio de simulações numéricas nota-se que a placa de carregamento influencia significativamente a distribuição de tensões ao longo do bloco. Quando ocorre deformação não uniforme na placa, as regiões centrais do bloco apresentam maiores deformações, influenciada pelo carregamento direto do atuador. Em contrapartida, quando a placa desloca-se uniformemente - com rigidez bastante elevada - os valores de deformação obtidos ao longo das paredes do bloco são mais uniformes.

Apesar da deformação da placa, nas simulações com prismas ocorre uma uniformização das tensões na região central da altura do elemento.

Os modelos numéricos não representam os ensaios realizados, contudo, apresentam o comportamento teórico em distintas condições de ensaio.

As associações entre resultados teóricos e experimentais apresentam resultados coerentes com o real comportamento do bloco.

Obteve-se o valor da força máxima nos ensaios de blocos, a partir das propriedades do concreto e deformações do bloco, próxima à aplicada pelo atuador da máquina de ensaio.

Pode-se prever a curva tensão-deformação do bloco vazado de concreto, referente aos pontos centrais, a partir das propriedades mecânicas do concreto que o constitui.

Acredita-se que a partir de métodos mais refinados, possivelmente considerando fatores de ponderação e/ou algoritmos genéricos, pode-se aprofundar os fatores interdependentes entre as propriedades mecânicas dos materiais e $\mathrm{o}$ comportamento de blocos vazados de concreto. 


\subsection{Proposta para trabalhos futuros}

Diante dos resultados encontrados neste trabalho, listam-se a seguir sugestões para pesquisas futuras:

- Realizar ensaios com geometrias de placas distintas e analisar a influência nas deformações ao longo das paredes do bloco vazado de concreto. Paralelamente, tal influência pode ser detalhada por meio de simulações numéricas não-lineares, considerando minuciosamente o comportamento das interfaces placa-capeamento e capeamento-bloco;

- Realizar análise experimental variando o material utilizado para capeamento dos blocos de concreto e verificar a influência do efeito de confinamento no comportamento dos blocos;

- Analisar teoricamente, por meio de simulações numéricas, as influências dos diversos tipos de capeamento m comportamento dos bloco vazados de concreto;

- Obter as reais propriedades da argamassa (resistência à compressão e à tração, módulo de elasticidade e coeficiente de Poisson) quando sob a forma de junta.

- Correlacionar as propriedades reais do concreto e argamassa com as dos elementos de alvenaria;

- Realizar simulações numéricas considerando as reais propriedades dos materiais constituintes da alvenaria;

- Correlacionar as propriedades mecânicas dos blocos vazados, moldados com concreto seco, com as propriedades do seu material constituinte. 


\section{REFERÊNCIAS BIBLIOGRÁFICAS}

AMERICAN CONCRETE INSTITUTE (1995). ACI 318-89: Building code requirements for masonry. Detroit, Michigan.

. (1995). ACI 530-92 / ASCE 5-92/ TMS 402-92: Building code requirements

for masonry. Detroit, Michigan.

AMERICAN SOCIETY FOR TESTING AND MATERIALS (1987). ASTM C 469: Static modulus of elasticity and Poisson's ratio of concrete in compression. Philadelphia.

. (1991). ASTM C 90. Standard specification for hollow load-bearing concrete masonry units. Philadelphia.

. (1996). ASTM C 1006: Standard test methods for splitting tensile strength of masonry units. Philadelphia.

. (1996). ASTM C 140: Standard test methods of sampling and testing concrete masonry units. Philadelphia.

ANDOLFATO, R.P.; CAMACHO, J.S.; MAURICIO, R.M. (2002). Blocos de concreto: A busca de um traço otimizado. Revista do IBRACON - Instituto Brasileiro do Concreto, São Paulo, ano X, n.29, p.32-39, abr/jun.

ANSYS RELEASE 5.5 (1999). Computational Applications and System Integration, Inc.. Engineering Analysis System. Manuais on-line.

ATKINSON, R.H. (1991). Effect of loading platen thickness on masonry unit and prism strengths. The Masonry Society Journal, Boulder, v.10, n.1, p.86-94, aug.

AUSTRALIAN STANDARD (1998). AS 3700: Masonry Structures.

ASSOCIAÇÃO BRASILEIRA DE CIMENTO PORTLAND (2000a). Produção de peças premoldadas de concreto. Curso sobre produção e controle de artefatos de cimento. São Paulo. 
. (2000b). Manual de ensaios de: agregados, concreto fresco e concreto endurecido. São Paulo.

ASSOCIAÇÃO BRASILEIRA DE NORMAS TÉCNICAS (1982). NBR 7251: Massa unitária de agregados em estado solto. Rio de Janeiro.

(1983). NBR 7211: Agregados para concreto. Rio de Janeiro.

(1984). NBR 8522: Concreto - Determinação do módulo de deformação estática e diagrama tensão-deformação. Rio de Janeiro.

(1987). NBR 7217: Agregados - Determinação da composição granulométrica.

Rio de Janeiro.

(1987). NBR 9776: Massa específica de agregado miúdo - Frasco de Chapman. Rio de Janeiro.

(1989). NBR 10837: Cálculo de alvenaria estrutural de blocos vazados de concreto. Rio de Janeiro.

(1991). NBR 12117: Blocos vazados de concreto para alvenaria - Retração por secagem. Rio de Janeiro.

(1991). NBR 12118: Bloco vazado de concreto simples para alvenaria Determinação da absorção de água, do teor de umidade e da área líquida. Rio de Janeiro.

(1992). NBR 7184: Blocos vazados de concreto simples para alvenaria Determinação da resistência à compressão. Rio de Janeiro.

. (1992). NBR 7223: Concreto - Determinação da consistência pelo batimento do tronco de cone. Rio de Janeiro.

(1994). NBR 6136: Bloco vazado de concreto simples para alvenaria estrutural. Rio de Janeiro.

. (1994). NBR 7222: Argamassa e concreto - Determinação da resistência à tração por compressão diametral de corpos-de-prova cilíndricos - Método de ensaio. Rio de Janeiro.

Janeiro.

(2003). NBR 6118: Projeto de estruturas de concreto - Procedimento. Rio de

BARBOSA, M.T.G. (2002). Metodologia de dosagem de argamassas mistas. In: ALVENARIA ESTRUTURAL: NOVAS TENDÊNCIAS TÉCNICAS E DE MERCADO. Rio de Janeiro: Interciência. p.11-18.

BARBOSA, C.S.; OLIVEIRA, F.L.; HANAI, J.B. (2003). Influência da variação geométrica dos blocos de concreto no comportamento dos prismas submetidos à compressão axial. In: SIMPÓSIO EPUSP SOBRE ESTRUTURAS DE CONCRETO, 5., 2003, São Paulo. Anais. 1 CD-ROM. 
BECICA, I.J.; HARRIS, H.G. (1983). Behavior of hollow concrete masonry prisms under axial load and bending. The Masonry Society Journal, Boulder, v.2, n.2, p.T1T26, jan-jun.

BRITISH STANDARDS INSTITUTION (1992). BS 5628: Code of practice for use of masonry. Part 1: Structural use of unreinforced masonry. London.

BRITISH STANDARDS INSTITUTION (1981). BS 6073: Specification for precast concrete masonry units. London.

CALÇADA, L.M.L. (1998). Avaliação do comportamento de prismas grauteados $e$ não grauteados de blocos de concreto. Dissertação (Mestrado) - Universidade Federal de Santa Catarina, Florianópolis, 1998. Disponível em: 〈http://www.infohab.org.br/>. Acesso em: 18 fev. 2003.

CAMACHO, J.S. (1986). Alvenaria Estrutural não armada - Parâmetros básicos a serem considerados no projeto dos elementos resistentes. Dissertação (Mestrado) Universidade Federal do Rio Grande do Sul, Porto Alegre. 1986.

CAPPUZO NETO, V. (2003). Interação de paredes em alvenaria estrutural sob ações verticais. 179p. Texto apresentado para o Exame de Qualificação (Doutoramento) Escola de Engenharia de São Carlos, Universidade de São Paulo, São Carlos. 2003.

CAVALHEIRO, O.P.; GOMES, N.G. (2002). Alvenaria estrutural de blocos vazados: resultados de ensaios de elementos e redutores de resistência à compressão. In: INTERNATIONAL SEMINAR ON STRUCTURAL MASONRY FOR DEVELOPING COUNTRIES, 7., 2002, Belo Horizonte. Proceedings. p.411-19.

CHEEMA, T.S.; KLINGNER, R.E. (1986). Compressive strength of concrete masonry prisms. ACI Journal, v.83, n.1, p.88-97, jan-feb.

COMITÉ EURO-INTERNACIONAL DO BÉTON (1990). CEB-FIP model code 1990. Bulletin d'Information.

CORRÊA, M.R.S. (2003). Fluxo de forças em edifícios de alvenaria estrutural . 156p. Tese (Livre-Docência) - Escola de Engenharia de São Carlos, Universidade de São Paulo, São Carlos. 2003.

DRYSDALE, R.G.; HAMID, A.A. (1979). Behavior of concrete block masonry under axial compression. ACI Journal, v.76, n.6, p.707-721, jun.

DRYSDALE, R.G.; HAMID, A.A.; BAKER, L.R. (1994). Masonry structures: behavior and design. Englewood Cliffs, New Jersey: Prentice Hall.

EUROCÓDIGO 6 (1995). ENV 1996-1-1: Proyecto de estructuras de fábrica. Reglas generales para edificios. Reglas para fábrica y fábrica armada. Madrid.

FRASSON JÚNIOR, A.F. (2000). Metodologia de dosagem e controle do processo produtivo de blocos de concreto para a alvenaria estrutural. 146p. Dissertação (Mestrado) - Universidade Federal de Santa Catarina, Florianópolis. 2000. 
GANZERLI, S. et al. (2003). Compression strength testing for nonstandard concrete masonry units. In: NORTH AMERICAN MASONRY CONFERENCE, 9., 2003, Clemson, South Carolina. Proceedings. p.60-71.

GOMES, N.G. (1983). A resistência das paredes de alvenaria. 191p. Dissertação (Mestrado) - Escola Politécnica, Universidade de São Paulo, São Paulo. 1983.

HAMID, A.A.; CHUKWUNENYE, A.O. (1986). Compression behavior of concrete masonry prisms. Journal of Structural Engineering, v.112, n.3, p.605-13, mar.

HAWK, S.W.; McLEAN, D.I.; YOUNG, T.C. (1997). Compressive behavior of insulated concrete masonry prisms. The Masonry Society Journal, v.15, n.2, p.53-60, dec.

HENDRY, A.W. (1998). Structural Masonry. 2.ed. Hong Kong : Macmillan Press Ltd.

HENDRY, A.W. (2001). Masonry walls: materials and construction. Construction and Building Materials, v. 15, p.323-80, dec.

JUSTE, A.E. (2001). Estudo da resistência e da deformabilidade da alvenaria de blocos de concreto submetida a esforços de compressão. 126p. Dissertação (Mestrado) - Escola de Engenharia de São Carlos, Universidade de São Paulo, São Carlos. 2001.

KLEEMAN, P.W.; PAGE, A.W. (1990). The in-situ properties of packing materials used in compression tests. Masonry International, London, v.4, n.2, p.68-74.

LA ROVERE, H.L.; RODRIGUES, R.M. (1997). Análise do comportamento mecânico de prismas de alvenaria de blocos de concreto pelo MEF. In: JORNADAS SULAMERICANAS DE ENGENHARIA ESTRUTURAL, 28., 1997, São Carlos. Anais. p.179-88.

LOURENÇO, P.J.B.B. (2003). Avanços recentes na caracterização experimental e na análise numérica de estruturas de alvenari: aplicações a construções antigas $e$ a construções novas. Palestra. Escola Politécnica, Universidade de São Paulo, São Paulo. 05 dez.

MARZAHN, G.A. (2003). Extended investigation of mechanical properties of masonry units. In: NORTH AMERICAN MASONRY CONFERENCE, 9., 2003, Clemson, South Carolina. Proceedings. p.813-24.

MAURENBRECHER, A.H.P. (1978). Use of the prism test to determine compressive strength of masonry. In: NORTH AMERICAN MASONRY CONFERENCE, 1., 1978, Boulder. Proceedings. Boulder: The Masonry Society.

MAURENBRECHER, A.H.P. (1980). Effect of test procedures on compressive strength of masonry prisms. In: CANADIAN MASONRY SYMPOSIUM, 2., 1980, Ottawa. Proceedings. Ottawa: Carleton University. p.119-32.

MEDEIROS, J.S. (1993). Alvenaria estrutural não armada de blocos de concreto: produção de componentes e parâmetros de projeto. 449p. Dissertação (Mestrado) Escola Politécnica, Universidade de São Paulo, São Paulo. 1993. 
MAURÍCIO, R.M. (2003). Investigação experimental da influência do capeamento na resistência de blocos de concreto para alvenaria estrutural. 52p. Relatório Final de Iniciação Científica apresentado à FAPESP - Faculdade de Engenharia de Ilha Solteira, Universidade Estadual Paulista, Ilha Solteira. 2003.

MOHAMAD, G. (1998). Comportamento mecânico na ruptura de prismas de blocos de concreto. 117p. Dissertação (Mestrado) - Universidade Federal de Santa Catarina, Florianópolis, 1998. Disponível em: 〈http://www.infohab.org.br/>. Acesso em: 18 fev. 2003.

MOHAMAD, G. (2004). Publicação eletrônica [mensagem pessoal]. Mensagem recebida por<claudius@sc.usp.br> em 24 jan.

MOHAMAD, G.; ROMAN, H.R.; SEGAVE, A.M. (2002a). Comportamento mecânico na ruptura de prismas de blocos de concreto. In: INTERNATIONAL SEMINAR ON STRUCTURAL MASONRY FOR DEVELOPING COUNTRIES, 7., 2002, Belo Horizonte. Proceedings. p.119-24.

MOHAMAD, G.; ROMAN, H.R.; SEGAVE, A.M. (2002b). Estudo do comportamento triaxial de argamassas. In: INTERNATIONAL SEMINAR ON STRUCTURAL MASONRY FOR DEVELOPING COUNTRIES, 7., 2002, Belo Horizonte. Proceedings. p.59-65.

MONDARDO, M.M.; KINDLEN, T.; CAMARGO, J.W. (1994). Resistência à compressão de prismas com argamassas de cimento cal e areia e cimento saibro e areia. In: INTERNATIONAL SEMINAR ON STRUCTURAL MASONRY FOR DEVELOPING COUNTRIES, 5., 1994, Florianópolis. Proceedings. p.176-84.

MORENO JÚNIOR., A.L.; ALBUQUERQUE, C.C. (2001). Influência da espessura das juntas de argamassa de assentamento no comportamento à compressão de prismas de alvenaria de blocos vazados de concreto. In: CONGRESSO BRASILEIRO DO CONCRETO, 42., 2001, São Paulo. Anais. São Paulo: IBRACON.

NEVILLE, A.M. (1997). Propriedades do concreto. Tradução Eng. Salvador E. Giammusso. 2ed. São Paulo: Pini.

PAGE, A.W.; KLEEMAN, P.W. (1991). The influence of capping material and platen restraint on the failure of hollow masonry units and prisms. In: INTERNATIONAL BRICK/BLOCK MASONRY CONFERENCE, 9., 1991, Berlin. Proceedings. p.662-70.

PRUDÊNCIO JR., L.R. (2003). Publicação eletrônica [mensagem pessoal]. Mensagem recebida por<claudius@sc.usp.br>em 5 ago.

RAMALHO, M.A.; CORRÊA, M.R.S. (2003). Projeto de edifícios de alvenaria estrutural. 1.ed. São Paulo: Pini.

RIZZATTI, E. (2003). Influência da geometria do bloco cerâmico no desempenho mecânico da alvenaria estrutural sob compressão. Tese (Doutorado) - Universidade Federal de Santa Catarina, Florianópolis. 2003.

ROMAGNA, R.H. (2000) Resistência à compressão de prismas de blocos de concreto grauteados e não grauteados. 195p. Dissertação (Mestrado) - Universidade Federal de 
Santa Catarina, Florianópolis, 2000. Disponível em: <http://www.infohab.org.br/>. Acesso em: 18 fev. 2003.

SABBATINI, F.H. (1984). O processo construtivo de edifícios de alvenaria estrutural sílico-calcária. 298p. Dissertação (Mestrado) - Escola Politécnica, Universidade de São Paulo, São Paulo. 1984.

SAHLIN, S. (1971). Structural Masonry. Englewood Cliffs, New Jersey: Prentice Hall.

SELF, M.W. (1975). Structural properties of load bearing concrete masonry. In: MASONRY: PAST AND PRESENT. Philadelphia: ASTM. Special technical publication, 589. p.233-254.

SHRIVE, N.G. (1982). The failure mechanism of face-shell bedded (ungrouted and unreinforced) masonry. In: INTERNATIONAL JOURNAL OF MASONRY CONSTRUCTION, London, v.2, n.3, p.115-28.

SOLÓRZANO, M.G.P. (1994). Características e desempenho de juntas de argamassa na alvenaria estrutural de blocos de concreto. 203p. Dissertação (Mestrado) - Escola Politécnica, Universidade de São Paulo, São Paulo. 1994.

STEIL, R.O.; PRUDÊNCIO JÚNIOR, L.R.(2002). Influência da geometria dos blocos no fator de eficiência das alvenarias estruturais de blocos de concreto. In: INTERNATIONAL SEMINAR ON STRUCTURAL MASONRY FOR DEVELOPING COUNTRIES, 7., 2002, Belo Horizonte. Proceedings. p.411-19.

TAKEYA, T. (2001). Análise experimental de estruturas. Notas de Aula. Escola de Engenharia de São Carlos, Universidade de São Paulo. 2001.

TANGO, C.E.S. (1994). Fundamentos de dosagem de concreto para blocos estruturais. In: INTERNATIONAL SEMINAR ON STRUCTURAL MASONRY FOR DEVELOPING COUNTRIES, 5., 1994, Florianopolis. Proceedings. p.21-30.

VEDACIT (2003). Disponível em: 〈http://www.vedacit.com.br/_novo2003/index.php〉. Acesso em: 17 out. 


\section{BIBLIOGRAFIA COMPLEMENTAR}

ANDRADE, A.A. (2000). Estabilidade das paredes de alvenaria estrutural: novo modo de verificação da segurança. São Paulo. 133p. Tese (Doutorado) - Escola Politécnica, Universidade de São Paulo, São Paulo, 2000.

FRANCO, L.S. (1987). Desempenho estrutural do elemento parede de alvenaria empregado na alvenaria estrutural não armada quando submetido a esforços de compressão. 136p. Dissertação (Mestrado) - Escola Politécnica, Universidade de São Paulo, São Paulo. 1987.

HELENE, P.R.L; TERZIAN, P. (1995). Manual de dosagem e controle do concreto. 1.ed. São Paulo: Pini.

EL-NAWAWY, O.A.; EL-HADDAD, M.H. (1990). Predication of strength and fracture behaviour of concrete masonry wall units. In: NORTH AMERICAN MASONRY CONFERENCE, 5., 1990, Illinois. Proceedings. Illinois: University of Illinois at Urbana-Champaign. p.563-80.

MALITE, M.; GIONGO, J.S. (1999). Segurança nas estruturas de concreto. In: NOVA NORMALIZAÇÃO BRASILEIRA PARA O CONCRETO ESTRUTURAL. 1.ed. Juiz de Fora: Interciência. p.71-101.

MAURENBRECHER, A.H.P. (1985). Axial compression tests on masonry walls and prisms. In: NORTH AMERICAN MASONRY CONFERENCE, 3., 1985, Arlington, Texas. Proceedings. p. 19/1-19/14.

MEDEIROS, J.S. (1994). Blocos de concreto para alvenaria estrutural: Avaliação de parâmetros básicos de produção. In: INTERNATIONAL SEMINAR ON STRUCTURAL MASONRY FOR DEVELOPING COUNTRIES, 5., 1994, Florianopolis. Proceedings. p.462-70.

MORENO JÚNIOR, A.L.; RIBEIRO, F.C.V.; FERNANDES, S.A. (2001). A influência do valor da base de medida das deformações no valor do módulo de deformação longitudinal de prismas de alvenaria de blocos vazados de concreto executados com diferentes espessuras das juntas e resistência à compressão da argamassa de assentamento. In: CONGRESSO BRASILEIRO DO CONCRETO, 42., 2001, São Paulo. Anais. São Paulo: IBRACON. 
OLIVEIRA, F.L.(2001). Reabilitação de paredes de alvenaria pela aplicação de revestimentos resistentes de argamassa armada. 195p.+anexos. Tese (Doutorado) Escola de Engenharia de São Carlos, Universidade de São Paulo, São Carlos. 2001.

PRUDÊNCIO JÚNIOR, L.R. (1986). Resistência à compressão da alvenaria e correlação entre a resistência de unidades, prismas e paredes. Dissertação (Mestrado) - Escola de Engenharia, Universidade Federal do Rio Grande do Sul. 1986.

SÁNCHEZ, E. (1994). Histórico sobre pesquisas e elaboração de novas normas no Brasil sobre Alvenaria Estrutural. In: INTERNATIONAL SEMINAR ON STRUCTURAL MASONRY FOR DEVELOPING COUNTRIES, 5., 1994, Florianopolis. Proceedings. p.368-74.

RILEM (2000). TC 148-SSC. Strain Softening of concrete - Test methods for compressive softening. Materials and Structures. v. 33, p.347-51. jul.

TARTUCE, R. (1997). Dosagem experimental do concreto. 1.ed. São Paulo: Ibracon/Pini.

VERMELTFOORT, A.TH. (1996). Effects of boundary conditions on compressive behaviour of brittle materials. In: NORTH AMERICAN MASONRY CONFERENCE, 7., 1996, Indiana. Proceedings. p.1130-41.

XIE, H.; PAGE, A.W.; KLEEMAN, P.W. (1998). The use of a new prism to define the behaviour of face-shell bedded hollow concrete masonry under axial compression. In: AUSTRALASIAN MASONRY CONFERENCE, 5., 1998, Gladstone. Proceedings. p.417-25 